EFEITO DOS MÉTODOS DE SÍNTESE E SINTERIZAÇÃO NA DENSIFICAÇÃO, ESTRUTURA, MICROESTRUTURA E CONDUTIVIDADE ELÉTRICA DO GALATO DE LANTÂNIO

SHIRLEY LEITE DOS REIS

Tese apresentada como parte dos requisitos para obtenção do Grau de Doutor em Ciências na Área de Tecnologia Nuclear - Materiais

Orientadora:

Profa. Dra. Eliana Navarro dos Santos Muccillo 
À Deus

Minha mãe, Cida Reis

Djalma Gomes 
"E tudo quanto fizerdes, fazei-o de coração, como ao Senhor, e não aos homens."

Colossenses 3:23 


\section{Agradecimentos}

Gostaria de agradecer...

Primeiramente a Deus, pelo amor tão especial, à minha orientadora, Dra. Eliana Navarro dos Santos Muccillo, pela orientação, apoio, incentivo e confiança.

ao Dr. Reginaldo Muccillo pelos ensinamentos e contribuições,

ao CNPq pela bolsa de doutorado concedida,

ao IPEN pela oportunidade de realizar esse trabalho,

a Yone V. França, por estar sempre cuidando do laboratório,

ao Laboratório de Microscopia Eletrônica do IPEN.

a minha mãe, que é um presente de Deus para mim. Suas orações, o seu amor, carinho, cuidado e cumplicidade permitiram que eu chegasse até aqui.

ao Djalma Gomes, que me incentiva, ajuda, ora e contribui muito na minha vida e com o seu amor faz os meus dias muito melhores.

a toda minha família que está sempre ao meu lado,

a todos aqueles que oraram por mim durante esse meu trabalho, especialmente aos meus amigos da minha igreja,

a todos os amigos que conquistei e que sempre me apoiaram nos meus estudos,

aos amigos do laboratório pelas discussões, contribuições e momentos que fizeram com que esse período fosse muito agradável, Rafael Morgado, Sabrina Carvalho, Talita Fujimoto, Tatiane Porfirio, Emanuelle Zangerolame e Mayra Dancini.

ao Robson Grosso pelas contribuições e apoio na parte de síntese química neste trabalho,

e aos membros da banca pelas contribuições nesse trabalho, Dra. Renata Ayres Rocha, Dr. Fabio Coral Fonseca, Dr. Jose Roberto Martinelli e Dra. Margarida Juri Saeki. 


\title{
EFEITO DOS MÉTODOS DE SÍNTESE E SINTERIZAÇÃO NA DENSIFICAÇÃO, ESTRUTURA, MICROESTRUTURA E CONDUTIVIDADE ELÉTRICA DO GALATO DE LANTÂNIO
}

\author{
Shirley Leite dos Reis
}

\section{Resumo}

O galato de lantânio contendo substituições parciais de estrôncio e magnésio ( $\left.\mathrm{La}_{1-x} \mathrm{Sr}_{x} \mathrm{Ga}_{1-y} \mathrm{Mg}_{y} \mathrm{O}_{3-\delta}\right)$ apresenta estrutura tipo perovsquita e alta condutividade para íons de oxigênio. Outras características desta cerâmica são o extenso domínio eletrolítico e a baixa condutividade eletrônica. É um material promissor para uso como eletrólito sólido em células a combustível de óxido sólido que operam em temperaturas intermediárias, devido sua alta condutividade iônica e estabilidade em uma ampla faixa de pressão parcial de oxigênio. Neste trabalho, a composição $\mathrm{La}_{0,9} \mathrm{Sr}_{0,1} \mathrm{Ga}_{0,8} \mathrm{Mgg}_{0,2} \mathrm{O}_{3-\delta}$ foi preparada pelo método convencional de mistura de óxidos a partir de diferentes rotas e pelo método de complexação de cátions. As amostras foram consolidadas pelo método convencional de sinterização e por sinterização rápida. Pelo método de mistura de óxidos foi possível obter a fase ortorrômbica do LSGM, mas não foi possível eliminar as fases $\mathrm{SrLaGaO}_{4}, \mathrm{La}_{4} \mathrm{Ga}_{2} \mathrm{O}_{9}$ e $\mathrm{SrLaGa}_{3} \mathrm{O}_{7}$, independente das condições de sinterização utilizadas. Precipitados de óxido de magnésio foram observados nas amostras preparadas pelos dois métodos de síntese empregados identificados apenas por microscopia eletrônica de varredura. As densidades obtidas foram superiores a $97 \%$ da densidade teórica em amostras sinterizadas a $1450{ }^{\circ} \mathrm{C} / 4 \mathrm{~h}$, para os materiais preparados por mistura de óxidos. Amostras preparadas por método de complexação de cátions e aquelas consolidadas por sinterização rápida apresentaram menores valores de densidade. Grãos de tamanhos micrométricos foram obtidos para os dois métodos de sinterização. Amostras calcinadas a $1250^{\circ} \mathrm{C}$ apresentaram maiores densidades e maiores valores de condutividade iônica dos grãos e dos contornos de grãos, quando comparadas com as demais amostras.

Palavras-chaves: galato de lantânio, mistura de óxidos, complexação de cátions, fases secundárias, sinterização convencional, sinterização rápida. 


\title{
EFFECTS OF THE SYNTHESIS AND SINTERING METHODS ON THE DENSIFICATION, STRUCTURE, MICROSTRUCTURE AND ELECTRICAL CONDUCTIVITY OF DOPED LANTHANUM GALLATE
}

\section{Shirley Leite dos Reis}

\begin{abstract}
Lanthanum gallate with partial substitution on $\mathrm{La}$ and $\mathrm{Ga}$ sites (La1-x $\left.\mathrm{Sr}_{x} \mathrm{Ga}_{1-y} \mathrm{Mg}_{y} \mathrm{O}_{3-\delta}\right)$ has perovskite structure and high oxide-ion conductivity. Other properties of this ceramic material comprise a relatively wide electrolytic domain and low electron conductivity. Doped lanthanum gallate is a potential solid electrolyte for intermediate-temperature solid oxide fuel cells due to its high ionic conductivity and stability in a wide range of oxygen partial pressure. In this work, the composition La0.9Sr0.1 $\mathrm{Ga}_{0.8} \mathrm{Mg}_{0.2} \mathrm{O}_{3-\delta}$ was prepared by the conventional method of mixing of the starting oxides followed by different processing routes and by the cation complexation method. The ceramic specimens were consolidated by conventional sintering and by fast firing. All specimens prepared by solid state reaction show the characteristic orthorhombic phase of lanthanum gallate and $\mathrm{SrLaGaO}_{4}, \mathrm{La}_{4} \mathrm{Ga}_{2} \mathrm{O}_{9}$ and $\mathrm{SrLaGa}_{3} \mathrm{O}_{7}$ secondary phases, independent on the method of sintering. Energy dispersive X-ray spectroscopy coupled to scanning electron microscopy evidenced that all prepared specimens contain $\mathrm{MgO}$ grains precipitated along the grain boundaries. High relative densities were obtained for specimens prepared by solid state reaction and consolidated by conventional sintering at $1450{ }^{\circ} \mathrm{C} / 4 \mathrm{~h}$. All specimens exhibit micron sized grains independent on the sintering method. The highest values of relative density and ionic conductivity were obtained for specimens calcined at $1250^{\circ} \mathrm{C}$.
\end{abstract}

Keywords: lanthanum gallate, solid state reaction, cation complexation technique, secondary phases, conventional sintering, fast firing. 


\section{Índice}

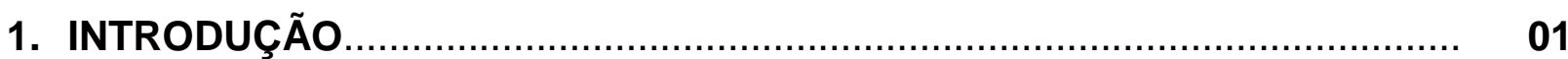

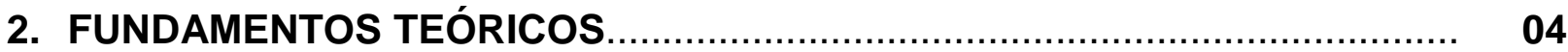

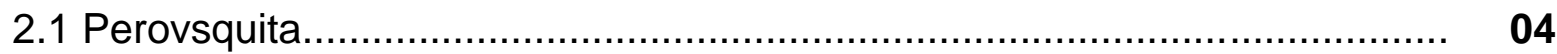

2.2 Galato de lantânio..................................................................... 05

2.3 Galato de lantânio com substituições de estrôncio e magnésio.................. 06

2.4 LSGM - Revisão da literatura ......................................................... 07

2.5 Complexação de Cátions...................................................................... 20

2.6 Sinterização Rápida.......................................................................... $\quad 21$

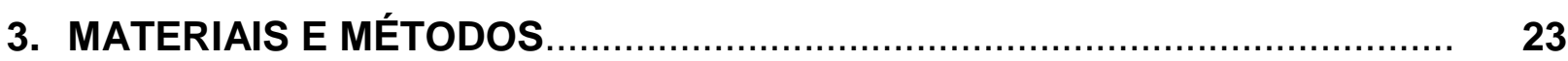

3.1 Materiais................................................................................... 23

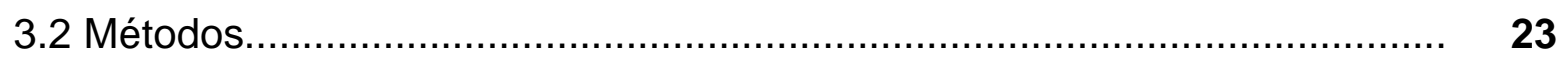

3.2.1 Mistura de óxidos.................................................................. 23

3.2.2 Complexação de cátions............................................................. 25

3.3 Caracterizações........................................................................... 27

4. RESULTADOS E DISCUSSÃO............................................................ 31

4.1 Caracterização dos pós............................................................. 31

4.1.1 Mistura de óxidos............................................................ $\quad 31$

4.1.2 Complexação de cátions................................................... 42

4.2 Caracterização das amostras sinterizadas......................................... 47

4.2.1 Sinterização Convencional..................................................... 47

4.2.2 Sinterização Rápida......................................................... 93

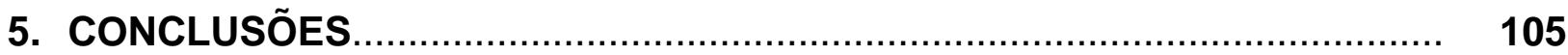

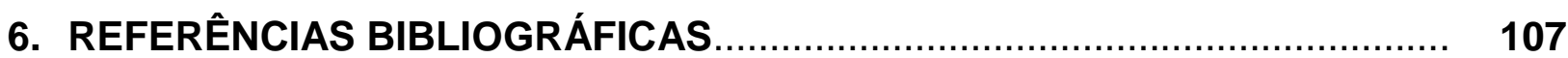




\section{Lista de Figuras}

Figura 1: Representação da estrutura perovsquita cúbica [15].

Estrutura do $\mathrm{LaGaO}_{3}$ (a) fase ortorrômbica e (b) romboédrica.

Figura 2: Em (a) La-círculos rosa, dois tipos de oxigênio - círculos verdes e azuis. Em (b) La - círculos vermelhos e O - círculos azuis. Ga ocupa o centro do octaedro (não aparece) [16].

Figura 3: $\quad$ Diagrama de fase do LSGM sinterizado a $1500{ }^{\circ} \mathrm{C}[48] \ldots \ldots \ldots \ldots \ldots \ldots \ldots . . . . . . . . . . .10$

Figura 4: Difratogramas de raios $X$ do pó de $\mathrm{La}_{2} \mathrm{O}_{3}$ como recebido e após o 24 tratamento térmico a $1000 \stackrel{\circ}{\circ} / 3 \mathrm{~h}-\left(^{*}\right) \mathrm{La}(\mathrm{OH})_{3}$

Figura 5: Fluxograma das rotas utilizadas no método de mistura de óxidos......

Figura 6: Fluxograma da sequência experimental do método de complexação de cátions...

Figura 7: $\quad$ Curvas termogravimétrica (TG) e de análise térmica diferencial (DTA) obtidas para o material com calcinações sucessivas a $1000^{\circ} \mathrm{C}$.

Figura 8: Difratogramas de raios $X$ dos pós com calcinações sucessivas a $1000{ }^{\circ} \mathrm{C}$ após a mistura, calcinações e moagem. 1- $\mathrm{La}_{2} \mathrm{O}_{3}, 2-\mathrm{SrCO}_{3}$, 3-SrLaGaO4, 4- $\mathrm{Ga}_{2} \mathrm{O}_{3}, 5-\mathrm{La}(\mathrm{OH})_{3}$ e 6-La4 $\mathrm{Ga}_{2} \mathrm{O}_{9}$.

Figura 9: Micrografias dos pós com calcinações sucessivas a $1000^{\circ} \mathrm{C}$, a) sem

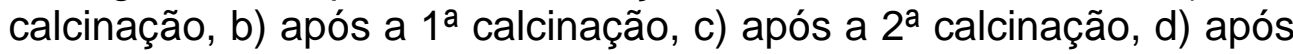
a $3^{\underline{a}}$ calcinação e) após moagem.

Figura 10: Difratogramas de raios $X$ dos pós com calcinações sucessivas a $1250{ }^{\circ} \mathrm{C}$ após a mistura, calcinações e moagem. 1- $\mathrm{La}_{2} \mathrm{O}_{3}$, 3-SrLaGaO 4 , 4-Ga2O $\mathrm{G}_{3}, 6-\mathrm{La}_{4} \mathrm{Ga}_{2} \mathrm{O}_{9}, 7-\mathrm{SrLaGa}_{3} \mathrm{O}_{7}$ e (*) LSGM

Figura 11: Micrografias dos pós com calcinações sucessivas a $1250{ }^{\circ} \mathrm{C}$, a) após

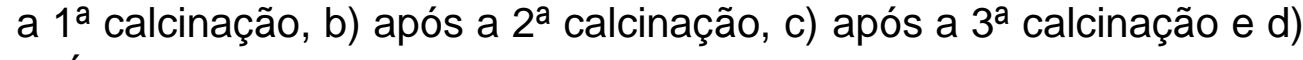
após moagem.

Figura 12: Difratogramas de raios $X$ dos pós preparados com calcinações sucessivas a $1350{ }^{\circ} \mathrm{C}$ após a mistura, calcinações e a moagem. 1- $\mathrm{La}_{2} \mathrm{O}_{3}, 3-\mathrm{SrLaGaO}_{4}, 4-\mathrm{Ga}_{2} \mathrm{O}_{3}, 6-\mathrm{La}_{4} \mathrm{Ga}_{2} \mathrm{O}_{9}$ 7-SrLaGa $\mathrm{O}_{7}$ e (*) LSGM.

Figura 13: Micrografias obtidas em microscópio eletrônico de varredura dos pós com calcinações sucessivas a $1350^{\circ} \mathrm{C}$ a) após a $1^{\text {a }}$ calcinação, b) após a $2^{\underline{a}}$ calcinação, c) após a 3aㅗ calcinação e d) após a moagem.... 
Figura 14: Difratogramas de raios $X$ dos pós com duas calcinações a $1350{ }^{\circ} \mathrm{C}$ com moagens intercaladas após a mistura, moagens e calcinações. 1- $\mathrm{La}_{2} \mathrm{O}_{3}, 3-\mathrm{SrLaGaO}_{4}, 4-\mathrm{Ga}_{2} \mathrm{O}_{3} 5-\mathrm{La}(\mathrm{OH})_{3}$ e ( $\left.{ }^{*}\right)$ LSGM.

Figura 15: Micrografias obtidas em microscópio eletrônico de varredura dos pós calcinados a $1350{ }^{\circ} \mathrm{C}$ com moagens intercaladas a) após $1^{\mathrm{a}}$ moagem, b) após $1^{\mathrm{a}}$ calcinação, c) após $2^{\mathrm{a}}$ moagem, d) $2^{\mathrm{a}}$ calcinação, e e) após $3^{\text {a }}$ moagem.

Figura 16: Curvas termogravimétrica (TG) e térmica diferencial (DTA) obtidas do material preparado pela técnica de complexação de cátions

Figura 17: Difratogramas de raios $X$ do material obtido pelo método de complexação de cátions, após a obtenção resina, pré-calcinação e calcinação. 1- $\mathrm{Sr}_{3} \mathrm{La}_{4} \mathrm{O}_{9}, 2$, $\mathrm{SrO}$ e ( $\left.{ }^{*}\right)$ LSGM.

Figura 18: Micrografias obtidas em microscópio eletrônico de varredura dos pós preparados pela técnica de complexação de cátions com diferentes aumentos: (a, b) após pré-calcinação, (c, d) após calcinação.

Figura 19: Curvas de retração linear dos compactos preparados com as misturas obtidas pelo método de complexação de cátions e mistura de óxidos.

Figura 20: Difratogramas de raios $X$ das pastilhas após sinterização a $1450^{\circ} \mathrm{C} /$ $4 \mathrm{~h}$ para as cinco rotas utilizadas no método de mistura de óxidos na faixa de $2 \theta$ entre (esquerda) 20 e $80^{\circ}$ e (direita) 25 e $32^{\circ}-\left(^{*}\right)$ LSGM, (1) $\mathrm{SrLaGaO}_{4}$, (2) $\mathrm{La}_{4} \mathrm{Ga}_{2} \mathrm{O}_{9}$ e (3) $\mathrm{SrLaGa}_{3} \mathrm{O}_{7}$

Figura 21: Difratogramas de raios $X$ das pastilhas com calcinações sucessivas a $1000{ }^{\circ} \mathrm{C}$ variando a temperatura de sinterização com tempo de patamar fixo de $2 \mathrm{~h}$ na faixa de $2 \theta$ entre (esquerda) 20 e $80^{\circ}$ e (direita) 25 e $32^{\circ}-\left(^{*}\right)$ LSGM, (1) $\mathrm{SrLaGaO}_{4,(2)} \mathrm{La}_{4} \mathrm{Ga}_{2} \mathrm{O}_{9}$ e (3) $\mathrm{SrLaGa}_{3} \mathrm{O}_{7}$

Figura 22: Difratogramas de raios $X$ das pastilhas com calcinações sucessivas a $1000^{\circ} \mathrm{C}$ variando o tempo de patamar com temperatura fixa de 1450 ${ }^{\circ} \mathrm{C}$ na faixa de $2 \theta$ entre (esquerda) 20 e $80^{\circ}$ e (direita) 25 e $32^{\circ}\left(^{*}\right)$ LSGM, (1) $\mathrm{SrLaGaO}_{4}$, (2) $\mathrm{La}_{4} \mathrm{Ga}_{2} \mathrm{O}_{9}$ e (3) $\mathrm{SrLaGa}_{3} \mathrm{O}_{7}$.

Figura 23: Difratogramas de raios $X$ das pastilhas com calcinações sucessivas a $1250{ }^{\circ} \mathrm{C}$ variando a temperatura de sinterização com tempo de patamar fixo de $2 \mathrm{~h}$ na faixa de $2 \theta$ entre (esquerda) 20 e $80^{\circ}$ e

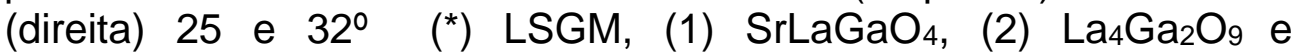
(3) $\mathrm{SrLaGa}_{3} \mathrm{O}_{7}$ 
Figura 24: Difratogramas de raios $X$ das pastilhas com calcinações sucessivas a $1250^{\circ} \mathrm{C}$ variando o tempo de patamar com temperatura fixa de 1450 C na faixa de $2 \theta$ entre (esquerda) 20 e 80ำ e (direita) 25 e 32ํ - ( ${ }^{*}$ ) LSGM, (1) $\mathrm{SrLaGaO}_{4},(2) \mathrm{La}_{4} \mathrm{Ga}_{2} \mathrm{O}_{9}$ e (3) $\mathrm{SrLaGa}_{3} \mathrm{O}_{7}$

Figura 25: Difratogramas de raios $X$ das pastilhas com calcinações sucessivas a $1350{ }^{\circ} \mathrm{C}$ variando a temperatura de sinterização com tempo de patamar fixo de $2 \mathrm{~h}$ na faixa de $2 \theta$ entre (esquerda) 20 e $80^{\circ}$ e (direita) 25 e $32^{\circ}$ - (*) LSGM, (1) $\mathrm{SrLaGaO}_{4},(2) \mathrm{La}_{4} \mathrm{Ga}_{2} \mathrm{O}_{9}$ e (3) $\mathrm{SrLaGa} \mathrm{O}_{7}$

Figura 26: Difratogramas de raios $X$ das pastilhas com calcinações sucessivas a $1350^{\circ} \mathrm{C}$ variando o tempo de patamar com temperatura fixa de 1450 ○C na faixa de $2 \theta$ entre (esquerda) 20 e $80^{\circ}$ e (direita) 25 e $32^{\circ}-\left(^{*}\right.$ ) LSGM, (1) $\mathrm{SrLaGaO}_{4}$,(2) $\mathrm{La}_{4} \mathrm{Ga}_{2} \mathrm{O}_{9}$ e (3) $\mathrm{SrLaGa}_{3} \mathrm{O}_{7}$

Figura 27: Difratogramas de raios $X$ das pastilhas com uma calcinação a $1350{ }^{\circ} \mathrm{C}$ com moagens intercaladas variando a temperatura de sinterização com tempo de patamar fixo de $2 \mathrm{~h}$ na faixa de $2 \theta$ entre (esquerda) 20 e 80 e (direita) 25 e 32 - (*) LSGM, (1) SrLaGaO4, (2) $\mathrm{La}_{4} \mathrm{Ga}_{2} \mathrm{O}_{9}$ e (3) $\mathrm{SrLaGa}_{3} \mathrm{O}_{7}$.

Figura 28: Difratogramas de raios $X$ das pastilhas com uma calcinação a $1350{ }^{\circ} \mathrm{C}$ com moagens intercaladas variando o tempo de patamar com temperatura fixa de $1450^{\circ} \mathrm{C}$ na faixa de $2 \theta$ entre (esquerda) 20

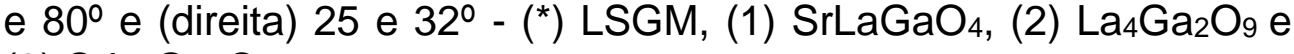

(3) $\mathrm{SrLaGa}_{3} \mathrm{O}_{7}$

Figura 29: Difratogramas de raios $X$ das pastilhas com duas calcinações a 1350 ${ }^{\circ} \mathrm{C}$ com moagens intercaladas variando a temperatura de sinterização com tempo de patamar fixo de $2 \mathrm{~h}$ na faixa de $2 \theta$ entre

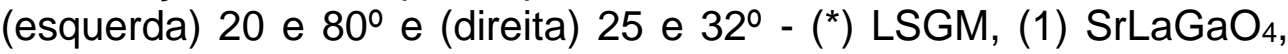
(2) $\mathrm{La}_{4} \mathrm{Ga}_{2} \mathrm{O}_{9}$ e (3) $\mathrm{SrLaGa}_{3} \mathrm{O}_{7}$

Figura 30: Difratogramas de raios $X$ das pastilhas com duas calcinações a 1350 ${ }^{\circ} \mathrm{C}$ com moagens intercaladas variando o tempo de patamar com temperatura fixa de $1450{ }^{\circ} \mathrm{C}$ na faixa de $2 \theta$ entre (esquerda) 20 e $80^{\circ}$ e (direita) 25 e 32ำ - (*) LSGM, (1) $\mathrm{SrLaGaO}_{4}$, (2) $\mathrm{La}_{4} \mathrm{Ga}_{2} \mathrm{O}_{9}$ e (3) $\mathrm{SrLaGa}_{3} \mathrm{O}_{7}$

Figura 31: Difratogramas de raios $X$ das pastilhas com calcinações sucessivas a $1250{ }^{\circ} \mathrm{C}$ e obtidas com duas calcinações a $1350^{\circ} \mathrm{C}$ com moagens intercaladas e sinterizadas a $1500{ }^{\circ} \mathrm{C} / 6 \mathrm{~h}$ na faixa de $2 \theta$ entre (esquerda) 20 e $80^{\circ}$ e (direita) 25 e $32^{\circ}-^{-}\left(^{*}\right)$ LSGM, (1) $\mathrm{SrLaGaO}_{4}$, (2) $\mathrm{La}_{4} \mathrm{Ga}_{2} \mathrm{O}_{9}$ e (3) $\mathrm{SrLaGa}_{3} \mathrm{O}_{7}$ 
Figura 32: Difratogramas de raios $X$ das pastilhas com duas calcinações a $1350{ }^{\circ} \mathrm{C}$ com moagens intercaladas antes e após o lixamento, sinterizadas a $1450^{\circ} \mathrm{C} / 4 \mathrm{~h}$

Figura 33: Difratogramas de raios $X$ das pastilhas obtidas pelo método de complexação de cátions variando a temperatura de patamar com tempo de patamar fixo de $4 \mathrm{~h}$. $\left(^{*}\right)$ LSGM

Figura 34: Difratogramas de raios $X$ das pastilhas obtidas pelo método de complexação de cátions variando o tempo de patamar com temperatura fixa de $1400^{\circ} \mathrm{C}$. $\left({ }^{*}\right)$ LSGM.

Figura 35: Micrografias obtidas em microscópio eletrônico de varredura de amostras sinterizadas a $1450{ }^{\circ} \mathrm{C} / 4 \mathrm{~h}$ obtidas pelo método de mistura de óxidos para as diferentes rotas com calcinações sucessivas a a) $1000^{\circ} \mathrm{C}$, b) $1250^{\circ} \mathrm{C}$ c) $1350^{\circ} \mathrm{C}$ e d) uma calcinação a $1350^{\circ} \mathrm{C}$ com moagens intercaladas, e) duas calcinações a $1350^{\circ} \mathrm{C}$ com moagens intercaladas.

Figura 36: Micrografias obtidas em microscópio eletrônico de varredura de amostras obtidas pelo método de mistura de óxidos com calcinações sucessivas a $1250{ }^{\circ} \mathrm{C}$ e sinterizadas a) $1450{ }^{\circ} \mathrm{C} / 1 \mathrm{~h}$, b) $1450{ }^{\circ} \mathrm{C} / 2 \mathrm{~h}$ e c) $1450^{\circ} \mathrm{C} / 4 \mathrm{~h}$

Figura 37: Micrografias obtidas em microscópio eletrônico de varredura de amostras obtidas pelo método de mistura de óxidos com calcinações sucessivas a $1250^{\circ} \mathrm{C}$ e sinterizadas com tempo de patamar fixo de $2 \mathrm{~h} \mathrm{a)} 1300^{\circ} \mathrm{C}$, b) $1350^{\circ} \mathrm{C}$, c) $1400^{\circ} \mathrm{C}$ e $1450^{\circ} \mathrm{C}$

Figura 38: Micrografias obtidas em microscópio eletrônico de varredura de amostras sinterizadas obtidas pelo método de mistura de óxidos calcinadas a $1350^{\circ} \mathrm{C}$ com moagens intercaladas a) $1450{ }^{\circ} \mathrm{C} / 1 \mathrm{~h}, \mathrm{~b}$ ) $1450^{\circ} \mathrm{C} / 2 \mathrm{~h}$ e c) $1450^{\circ} \mathrm{C} / 4 \mathrm{~h}$

Figura 39: Micrografias obtidas em microscópio eletrônico de varredura de amostras sinterizadas a $1500^{\circ} \mathrm{C} / 6 \mathrm{~h}$ obtidas pelo método de mistura de óxidos a) calcinações sucessivas a $1250{ }^{\circ} \mathrm{C}$ b) com duas calcinações a $1350^{\circ} \mathrm{C}$ com moagens intercaladas.

Figura 40: Micrografias obtidas em microscópio eletrônico de varredura de amostras sinterizadas obtidas pelo método de complexação de cátions com tempo fixo de $4 \mathrm{~h}$ variando a temperatura de patamar: a) $1350^{\circ} \mathrm{C}$, b) $\left.1400^{\circ} \mathrm{C}, \mathrm{c}\right) 1450^{\circ} \mathrm{C}$, d) $1500^{\circ} \mathrm{C}$

Figura 41: Micrografias obtidas em microscópio eletrônico de varredura de amostras sinterizadas obtidas pelo método de complexação de cátions com temperatura fixa de $1400{ }^{\circ} \mathrm{C}$ variando o tempo de patamar. 
Figura 42: a) micrografia obtida por elétrons retroespalhados, b) mapeamento dos elementos por EDS, c) espectro dos elementos da região 1, de amostras com calcinações sucessivas a $1250^{\circ} \mathrm{C}$ e sinterizadas a $1450{ }^{\circ} \mathrm{C} / 4$ h. (Vermelho-Mg; verde-Sr; azul-Ga e roxoLa).

Figura 42: d) espectro dos elementos da região 2, e) espectro dos elementos da (cont.) matriz, de amostras com calcinações sucessivas a $1250{ }^{\circ} \mathrm{C}$ e sinterizadas a $1450^{\circ} \mathrm{C} / 4 \mathrm{~h}$. (Vermelho-Mg; verde-Sr; azul-Ga e roxoLa)

Figura 43: a) micrografia obtida por elétrons retroespalhados e b) mapeamento dos elementos por EDS, c) espectro dos elementos da região 1, de amostras com calcinações sucessivas a $1250{ }^{\circ} \mathrm{C}$ e sinterizadas a $1500{ }^{\circ} \mathrm{C} / 6$ h. (Vermelho-Mg; verde-Sr; azul-Ga e roxoLa).

Figura 43: d) espectro dos elementos da região 2, e) espectro dos elementos da (Cont.) matriz de amostras com calcinações sucessivas a $1250{ }^{\circ} \mathrm{C}$ e sinterizadas a $1500^{\circ} \mathrm{C} / 6 \mathrm{~h}$. (Vermelho-Mg; verde-Sr; azul-Ga e roxoLa)

Figura 44: a) Micrografia obtida por elétrons retroespalhados, b) mapeamento dos elementos por EDS, c) espectro dos elementos da região 1, de amostras com duas calcinações a $1350{ }^{\circ} \mathrm{C}$ com moagens intercaladas e sinterizadas a $1500{ }^{\circ} \mathrm{C} / 6 \mathrm{~h}$. (Vermelho-Mg; verde-Sr; azul-Ga e roxo-La). As regiões c), d) e e) são ampliações da região delimitada na figura $44 a$.

Figura 44: d) espectro dos elementos da região 2, e) espectro dos elementos da (Cont.) matriz, de amostras com duas calcinações a $1350^{\circ} \mathrm{C}$ com moagens intercaladas e sinterizadas a $1500^{\circ} \mathrm{C} / 6 \mathrm{~h}$. (Vermelho-Mg; verde-Sr; azul-Ga e roxo-La) As regiões c), d) e e) são ampliações da região delimitada na figura $44 a$.

Figura 45: a) Micrografia obtida por elétrons retroespalhados, b) mapeamento dos elementos por EDS, das amostras preparadas pelo método de complexação de cátions sinterizadas a $1450 \stackrel{\circ}{\circ} / 4 \mathrm{~h}$. (Vermelho-Mg; verde-Sr; azul-Ga e roxo-La)

Figura 45: c) mapeamento do Mg por EDS, c) espectro dos elementos da região (cont.) 2, d) espectro dos elementos da matriz, das amostras preparadas pelo método de complexação de cátions sinterizadas a $1450{ }^{\circ} \mathrm{C} / 4 \mathrm{~h}$. (Vermelho-Mg; verde-Sr; azul-Ga e roxo-La).

Figura 46: Diagramas de impedância das amostras preparadas pelo método de mistura de óxidos e sinterizadas a $1450{ }^{\circ} \mathrm{C} / 4 \mathrm{~h}$. Gráfico interno: Região de alta frequência. 
Figura 47: Diagramas de impedância das amostras com calcinações sucessivas a $1250^{\circ} \mathrm{C}$ e sinterizadas em diferentes temperaturas de sinterização com patamar fixo de $2 \mathrm{~h}$. Gráfico interno: Região de alta frequência...

Figura 48: Diagramas de impedância das amostras com duas calcinações a $1350{ }^{\circ} \mathrm{C}$ com moagens intercaladas e sinterizadas em diferentes temperaturas com o tempo de patamar fixo de $2 \mathrm{~h}$.

Figura 49: Diagramas de impedância das amostras com duas calcinações a $1350^{\circ} \mathrm{C}$ com moagens intercaladas e sinterizadas na temperatura de $1450{ }^{\circ} \mathrm{C}$ variando o tempo de patamar. Gráfico interno: Região de alta frequência.

Figura 50: Diagramas de impedância das amostras com calcinações sucessivas a $1250{ }^{\circ} \mathrm{C}$ e preparadas com duas calcinações a $1350{ }^{\circ} \mathrm{C}$ com moagens intercaladas e sinterizadas a $1450{ }^{\circ} \mathrm{C} / 4 \mathrm{~h}$ e $1500^{\circ} \mathrm{C} / 6 \mathrm{~h}$. Gráfico interno: Região de alta frequência.

Figura 51: Diagramas de impedância das amostras sinterizadas preparadas pelo método de complexação de cátions para o tempo de patamar fixo de $4 \mathrm{~h}$ variando a temperatura de sinterização. Gráfico interno: Região de alta frequência.

Figura 52: Diagramas de impedância das amostras sinterizadas preparadas pelo método de complexação de cátions para a temperatura fixa de $1400^{\circ} \mathrm{C}$ variando o tempo de patamar.

Figura 53: Gráficos de Arrhenius da condutividade elétrica dos grãos (superior) e contornos de grãos (inferior) das amostras preparadas por mistura de óxidos e pelo método de complexação de cátions e sinterizadas a $1450 \stackrel{\circ}{\circ} / 4 \mathrm{~h}$.

Figura 54: Gráficos de Arrhenius da condutividade elétrica dos grãos e contornos de grãos das amostras sinterizadas a $1450{ }^{\circ} \mathrm{C} / 4 \mathrm{~h}$ e $1500{ }^{\circ} \mathrm{C} / 6 \mathrm{~h}$ com calcinações sucessivas a $1250{ }^{\circ} \mathrm{C}$ e com duas calcinações a $1350^{\circ} \mathrm{C}$

Figura 55: Gráficos de Arrhenius da condutividade elétrica dos grãos das amostras sinterizadas e preparadas pelo método de complexação de cátions para o tempo de patamar fixo de $4 \mathrm{~h}$ variando a temperatura.

Figura 56: Gráficos de Arrhenius da condutividade elétrica dos grãos das amostras sinterizadas e preparadas pelo método de complexação de cátions para a temperatura fixa de $1400{ }^{\circ} \mathrm{C}$ variando o tempo de patamar. 
Figura 57: Difratogramas de raios $X$ das pastilhas com calcinações sucessivas a $1250^{\circ} \mathrm{C}$ após sinterização rápida na faixa de $2 \theta$ entre (esquerda) $20 \mathrm{e}$ $80^{\circ}$ e (direita) 25 e $32^{\circ}$ - (*) LSGM, (1) SrLaGaO, (2) $\mathrm{La}_{4} \mathrm{Ga}_{2} \mathrm{O}_{9}$ e (3) $\mathrm{SrLaGa}_{3} \mathrm{O}_{7}$.

Figura 58: Difratogramas de raios $X$ das pastilhas com duas calcinações a $1350^{\circ} \mathrm{C}$ com moagens intercaladas após sinterização rápida na faixa de $2 \theta$ entre (esquerda) 20 e $80^{\circ}$ e (direita) 25 e $32^{\circ}-\left({ }^{*}\right)$ LSGM, (1) $\mathrm{SrLaGaO}_{4}$,(2) $\mathrm{La}_{4} \mathrm{Ga}_{2} \mathrm{O}_{9}$ e (3) $\mathrm{SrLaGa}_{3} \mathrm{O}_{7}$

Figura 59: Difratogramas de raios $X$ das pastilhas preparadas pelo método de complexação de cátions após sinterização rápida na faixa de $2 \theta$ entre (esquerda) 20 e $80^{\circ}$ e (direita) 25 e $32^{\circ}-\left(^{*}\right)$ LSGM, (1) $\mathrm{SrLaGaO}_{4}$, (2) $\mathrm{La}_{4} \mathrm{Ga}_{2} \mathrm{O}_{9}$ e (3) $\mathrm{SrLaGa}_{3} \mathrm{O}_{7}$

Figura 60: Micrografias obtidas em microscópio eletrônico de varredura de amostras preparadas pelo método de mistura de óxido com calcinações sucessivas a $1250^{\circ} \mathrm{C}$ obtidas por sinterização rápida a) $1450^{\circ} \mathrm{C} / 5 \mathrm{~min}$, b) $1450{ }^{\circ} \mathrm{C} / 10 \mathrm{~min}$ e c) $1500^{\circ} \mathrm{C} / 5 \mathrm{~min}$.

Figura 61: Micrografias obtidas em microscópio eletrônico de varredura de amostras preparadas pelo método de mistura de óxido com duas calcinações sucessivas a $1350^{\circ} \mathrm{C}$ com moagens intercaladas obtidas por sinterização rápida a) $1450{ }^{\circ} \mathrm{C} / 5 \mathrm{~min}$, b) $1450{ }^{\circ} \mathrm{C} / 10 \mathrm{~min}$ e c) $1500^{\circ} \mathrm{C} / 5 \mathrm{~min}$.

Figura 62: Micrografias obtidas em microscópio eletrônico de varredura de amostras preparadas pelo método de complexação obtidas por sinterização rápida a) $1450{ }^{\circ} \mathrm{C} / 5 \mathrm{~min}$, b) $1450{ }^{\circ} \mathrm{C} / 10 \mathrm{~min} \mathrm{e}$ c) $1500^{\circ} \mathrm{C} / 5 \mathrm{~min}$.

Figura 63: Gráficos de Arrhenius da condutividade elétrica dos grãos e contornos de grãos das amostras com calcinações sucessivas a $1250^{\circ} \mathrm{C}$ e obtidas por sinterização rápida.

Figura 64: Gráficos de Arrhenius da condutividade elétrica dos grãos e contornos de grãos das amostras com duas calcinações a $1350^{\circ} \mathrm{C}$ com moagens intercaladas e obtidas por sinterização rápida.

Figura 65: Gráficos de Arrhenius da condutividade elétrica dos grãos das amostras preparadas pelo método de complexação de cátions e obtidas por sinterização rápida. 


\section{Lista de Tabelas}

Tabela I - Valores de condutividade iônica, $\sigma$, a $600 \stackrel{\circ}{\circ}$ p para o LSGM.......... 11

Tabela II - $\quad$ Materiais de partida para a síntese do LSGM............................... 23

Tabela III - Características das fases cristalinas de interesse.......................... 28

Tabela IV - Retração total até $1500{ }^{\circ} \mathrm{C}$ e temperatura inicial dos compactos 46 preparados pelas diferentes rotas.

Tabela V - Índices dos elementos dos pós de LSGM determinados por fluorescência de raios $\mathrm{X}$.

Tabela VI - Índices dos elementos das amostras de LSGM sinterizadas em diversas condições determinados por fluorescência de raios $\mathrm{X}$.......

Tabela VII - Densidade relativa (em \% DT) das amostras sinterizadas preparadas pelo método de mistura de óxidos para as rotas utilizadas.

Tabela VIII - Densidade relativa (em \% DT) das amostras sinterizadas preparadas pelo método de complexação de cátions variando a temperatura com o tempo de patamar fixo de $4 \mathrm{~h}$ e com a temperatura de patamar fixa $1400{ }^{\circ} \mathrm{C}$, variando o tempo de patamar

Tabela IX - Tamanho médio de grãos para as amostras preparadas por 70 mistura de óxidos sinterizadas em diversas condições.

Tabela X - Tamanho médio de grãos para as amostras preparadas pelo método de complexação de cátions, sinterizadas em diversas condições.

Tabela XI - Valores de energia de ativação do processo de condução dos grãos $\left(E_{g}\right)$ contornos de grão $\left(E_{c g}\right)$ e total $\left(E_{T}\right)$, para amostras preparadas pelo método de mistura de óxidos e pelo método de complexação de cátions $(C)$ e valores de condutividade total na temperatura de $360^{\circ} \mathrm{C}$ para amostras preparadas pelo método de mistura de óxidos.

Tabela XII - Densidade relativa das amostras preparadas por mistura de óxidos com calcinações sucessivas a $1250{ }^{\circ} \mathrm{C}$, com duas calcinações a $1350^{\circ} \mathrm{C}$ com moagens intercaladas e preparadas por complexação de cátions e obtidas por sinterização rápida. 
Tabela XIII - Tamanho médio de grãos para as amostras preparadas por mistura de óxidos e complexação de cátions obtidas por sinterização rápida..

Tabela XV - Valores de energia de ativação do processo de condução dos grãos $\left(E_{g}\right)$ contornos de grão $\left(E_{c g}\right)$ e total $\left(E_{T}\right)$, para amostras preparadas pelo método de mistura de óxidos e pelo método de complexação de cátions $(C)$ e valores de condutividade total na temperatura de $360^{\circ} \mathrm{C}$ para amostras preparadas pelo método de mistura de óxidos. 


\section{INTRODUÇÃO}

Condutores de íons oxigênio formam uma classe de materiais funcionais com aplicações tecnológicas em diversas áreas incluindo sensores de espécies químicas, bombas de oxigênio, membranas permeáveis ao oxigênio e células a combustível para produção de energia [1-3].

Dentre os principais tipos de células a combustível que trabalham em altas temperaturas, podemos destacar as células a combustível de óxido sólido que são compostas por um eletrólito sólido, catodo e anodo, todos cerâmicos. Outros componentes importantes são os interconectores e selante. Diversos conjuntos como esse compõem um empilhamento ("stack") capaz de gerar eletricidade para diversas aplicações [4].

Existem vários requisitos que são comuns a todos os componentes de uma célula a combustível de óxido sólido, tais como: estabilidade química no ambiente da célula, compatibilidade com os demais componentes da célula, estabilidade de fase e microestrutural. Além disso, os componentes estruturais devem apresentar boa resistência mecânica e tenacidade à fratura na temperatura de operação da célula, além de razoável resistência ao choque térmico [5].

Idealmente um eletrólito sólido é condutor de uma única espécie química e um isolante eletrônico. Isto significa que a concentração de defeitos iônicos deve ser muito superior à de defeitos eletrônicos. A condutividade iônica é influenciada por fatores como pureza dos materiais de partida e parâmetros de processamento, tais como: introdução de aditivos, moagem e tratamentos térmicos (calcinação, sinterização e envelhecimento), que definem a microestrutura do material sinterizado.

O eletrólito sólido mais desenvolvido para ser utilizado numa célula a combustível de óxido sólido é a zircônia estabilizada com ítria (YSZ). A temperatura de operação neste caso está na faixa de 800 a $1000{ }^{\circ} \mathrm{C}$. Altas temperaturas de operação estabelecem limites rigorosos na escolha de outros materiais componentes da célula (eletrodo e interconector). As reações interfaciais entre os componentes a uma temperatura tão alta tendem a 
degradar o desempenho da célula e diminuir o tempo de vida devido a difusão e oxidação. Portanto, materiais alternativos para eletrólitos com suficiente condutividade iônica e alta estabilidade em baixas temperaturas são essenciais para melhorar a performance da célula [6].

A fim de reduzir a temperatura de operação da célula a combustível de óxido sólido, muitas pesquisas estão sendo realizadas no desenvolvimento de novos eletrólitos para a temperatura de operação entre $500-800{ }^{\circ} \mathrm{C}$ [7].

Nos últimos 20 anos, o desenvolvimento de materiais com estrutura diferente da fluorita tem ganhado muito interesse. T. Ishihara, H. Matsuda, Y. Takita [8] e M. Feng e J. B. Goodenough [9] relataram um novo eletrólito para temperaturas intermediárias a base de $\mathrm{LaGaO}_{3}$ (galato de lantânio) com estrutura perovsquita $\left(\mathrm{ABO}_{3}\right)$ contendo substituições de $\mathrm{Sr}$ e $\mathrm{Mg}$ nas posições do lantânio e gálio, respectivamente, que exibe uma condutividade três vezes maior do que a $\mathrm{YSZ}$ a $800^{\circ} \mathrm{C}$ [10].

Apesar de sua elevada condutividade iônica o galato de lantânio contendo estrôncio e magnésio (LSGM) normalmente apresenta fases secundárias [11], principalmente $\mathrm{La}_{4} \mathrm{Ga}_{2} \mathrm{O}_{9}, \mathrm{SrLaGa}_{3} \mathrm{O}_{7}$ e $\mathrm{SrLaGaO}_{4}$. Estas fases secundárias podem influenciar a condutividade elétrica da cerâmica, além de comprometer sua estabilidade térmica em longo prazo [12,13].

Considerando que o galato de lantânio é um material de grande interesse tecnológico, e que ainda não se tem um entendimento completo da importância das fases secundárias na performance do eletrólito, os principais objetivos deste trabalho são:

- Obter a composição $\mathrm{La}_{0,9} \mathrm{Sr}_{0,1} \mathrm{Gaa}_{0,8} \mathrm{Mg}_{0,2} \mathrm{O}_{3-8}$ pelo método convencional de reação em estado sólido, sem fases secundárias ou com menor teor possível de fases secundárias, empregando etapas de moagem e calcinação.

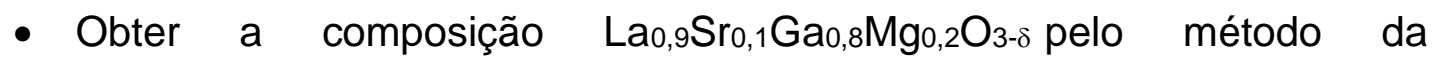
complexação de cátions utilizando o ácido cítrico como agente complexante visando obter boa homogeneidade química e estrutural, além de minimizar o teor de fases secundárias.

- Estudo da microestrutura, densificação e a condutividade elétrica do LSGM de amostras sinterizadas pelo método convencional e por 
sinterização rápida em amostras obtidas pelos dois métodos de síntese empregados.

- Investigar a influência da formação das fases secundárias na densificação, microestrutura e condutividade elétrica do galato de lantânio. 


\section{FUNDAMENTOS TEÓRICOS}

\subsection{Perovsquita}

As perovsquitas são compostos cerâmicos combinando elementos metálicos com não-metálicos que possuem um arranjo atômico particular. $\mathrm{Na}$ sua forma ideal a perovsquita possui composição estequiométrica $A B X_{3}$, sendo $A$ e $B$ cátions, onde $A$ é o maior dos átomos, divalente ou trivalente, e $B$ representa um cátion trivalente ou tetravalente com raio iônico pequeno e $\mathrm{X}$ um ânion formado geralmente por membros da família dos halogênios, como flúor, cloro, bromo ou oxigênio [14].

A estrutura ideal da perovsquita é cúbica, na qual o cátion $B$ ocupa 0 centro de cada cubo, os cátions $A$ ocupam 8 vértices e os ânions situam-se na metade de cada face do cubo. Entre as perovsquitas, as de estrutura $\mathrm{ABO}_{3}$, Figura 1a, têm inúmeras aplicações e tem dado a este tipo de composto um grande destaque na área da pesquisa $[14,15]$.

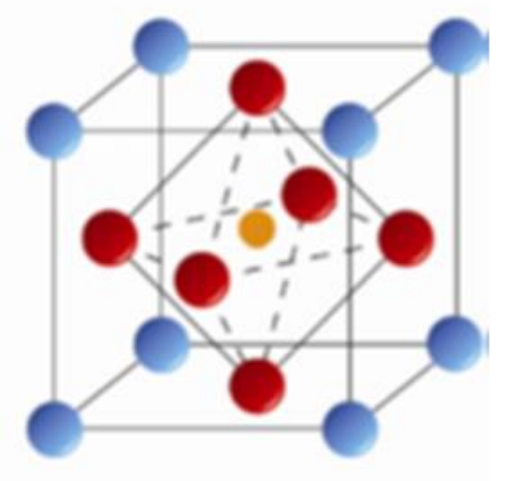

(a)

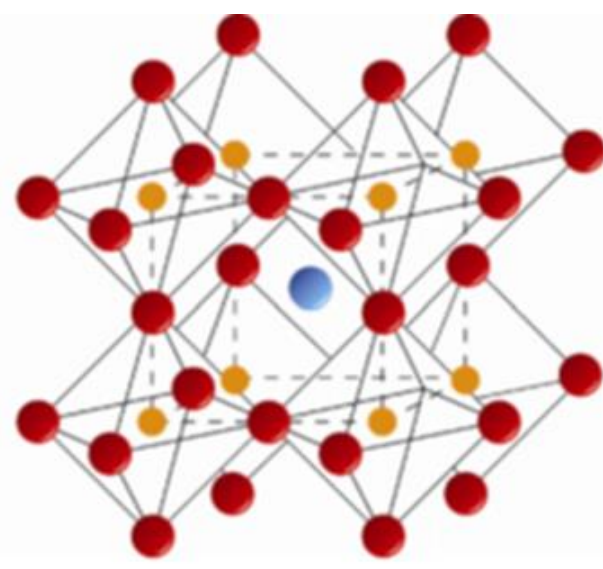

(b)

Figura 1: Representação da estrutura perovsquita cúbica [15].

Várias perovsquitas tem sua estrutura deformada, principalmente devido o cátion central $B$ ser muito pequeno em relação ao cátion $A$ nos vértices do cubo. Com isto, os átomos de oxigênio e os átomos $A$ são levemente deslocados de suas posições. Estes movimentos são melhores visualizados considerando a estrutura perovsquita como sendo formada por um conjunto de 
octaedros. Cada átomo B, centro do octaedro, é rodeado por 6 átomos de oxigênio. Os ânions definem o vértice do octaedro, Figura 1b [16].

O cátion $A$, está cercado por 8 octaedros, tendo cada um deles um cátion $B$ no centro, Figura $1 b$. Se o cátion $B$ é muito pequeno em relação ao cátion $\mathrm{A}$, os octaedros cujos eixos estão todos alinhados à aresta do cubo numa perovsquita ideal, inclinam-se e giram-se fazendo com que a estrutura ao redor de B seja modificada, distorcendo a simetria espacial de cúbica para tetragonal, romboédrica ou ortorrômbica. E assim, são alteradas as propriedades físicas da perovsquita [16].

O grande interesse científico em materiais com estrutura perovsquita surge de suas interessantes propriedades físicas, como propriedades ferroelétricas, magnéticas e ópticas. Além disso, a estrutura perovsquita é passível de diversos tipos de substituição e modificação na composição, de modo a obter uma propriedade desejada.

Alterações drásticas nas propriedades físicas são observadas em materiais tipo perovsquita, seja por uma ligeira modificação da estrutura, ou pela inclusão de defeitos, substituição química ou por uma alteração das condições externas, tais como: temperatura e pressão. A formação de vacâncias aniônicas nesta estrutura se dá pela substituição parcial de $A$ e/ou de $B$ por cátions de menor valência [16, 17].

As perovsquitas com estrutura ideal são geralmente isolantes elétricos. Todos os sítios estão ocupados e as ligações químicas iônicas fortes mantêm os átomos em suas posições normais da rede cristalina. Como consequência, a mobilidade dos elétrons pelo cristal é muito pequena. Além disso, como as ligações iônicas ao longo de cada um dos três eixos são muito parecidas, as propriedades da cerâmica, tais como compressibilidade e condutividade elétrica, são isotrópicas [16].

\subsection{Galato de lantânio}

O galato de lantânio $\left(\mathrm{LaGaO}_{3}\right)$ é uma perovsquita com estrutura tipo $\mathrm{GdFeO}_{3}$. A investigação sobre o $\mathrm{LaGaO}_{3}$ iniciou-se em 1957 [18], quando uma rede ortorrômbica resultante da distorção octaédrica foi atribuída ao sistema. 
É conhecido que $\mathrm{o} \mathrm{LaGaO}_{3}$ tem uma estrutura perovsquita ortorrômbica distorcida (Pbnm) em condições ambientes, Figura. 2a, e sofre transição de fase para romboédrica distorcida $(\mathrm{R} \overline{\mathrm{3}} \mathrm{c})$ em torno de $150{ }^{\circ} \mathrm{C}$, Figura $2 \mathrm{~b}[19]$.

a)

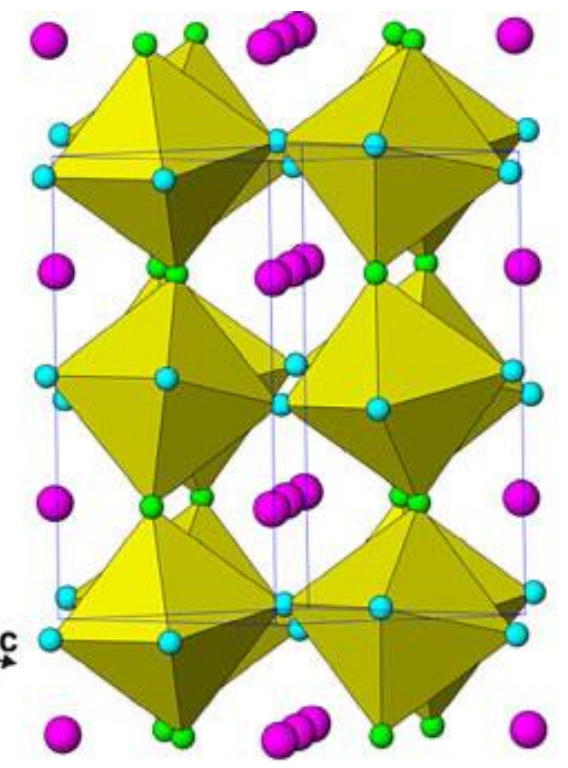

b)

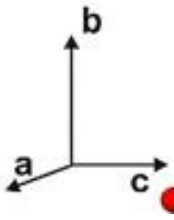

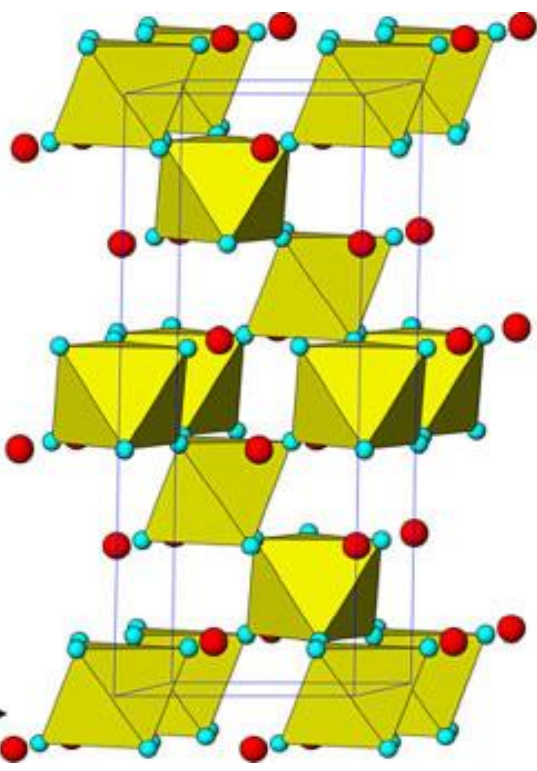

Figura 2: Estrutura do $\mathrm{LaGaO}_{3}$ (a) fase ortorrômbica e (b) romboédrica. Em (a) La-círculos rosa, dois tipos de oxigênio - círculos verdes e azuis. Em (b) $\mathrm{La}$ - círculos vermelhos e O - círculos azuis. Ga ocupa o centro do octaedro (não aparece) [16].

Cerâmicas a base de $\mathrm{LaGaO}_{3}$ podem apresentar valores maiores de condutividade iônica em função de substituições apropriadas de cátions na rede cristalina, nos sítios do La e Ga.

\subsection{Galato de lantânio com substituições de estrôncio e magnésio}

Em 1994, T. Ishihara e colaboradores [8] e M. Feng e J. B. Goodenough [9] desenvolveram o galato de lantânio contendo substituições parciais de estrôncio e magnésio (LSGM), que apresenta elevada condutividade iônica quando comparado com os condutores de íons oxigênio convencionais, como a zircônia estabilizada com ítria. Esta propriedade é de grande interesse tecnológico para aplicação como eletrólito sólido em células a combustível de óxido sólido operando em temperaturas intermediárias $\left(500-700^{\circ} \mathrm{C}\right)$. 
T. Ishihara e colaboradores [8] substituíram parcialmente com $\mathrm{Sr}^{2+}, \mathrm{Ba}^{2+}$ e $\mathrm{Ca}^{2+}$ no sítio do La e concluíram que o $\mathrm{Sr}^{2+}$ é mais efetivo do que o $\mathrm{Ba}^{2+}$ e o $\mathrm{Ca}^{2+}$ no aumento da condutividade elétrica do galato de lantânio. A quantidade de $0,1 \mathrm{em} \mathrm{mol} \mathrm{de} \mathrm{Sr}^{2+}$ foi considerada ótima em relação a condutividade, mas promoveu a formação de fases secundárias. $\mathrm{Mg}^{2+}, \mathrm{In}^{3+}$ e $\mathrm{Al}^{3+}$ foram parcialmente substituídos no sítio do $\mathrm{Ga}$, sendo que o $\mathrm{Mg}^{2+}$ possibilitou obter a melhor condutividade elétrica. Foi verificado que a composição $\mathrm{La}_{0,9} \mathrm{Sr}_{0,1} \mathrm{Ga}_{0,8} \mathrm{Mg}_{0,2} \mathrm{O}_{3+\delta}$ apresentou condutividade maior do que a zircônia estabilizada com ítria (YSZ) em uma ampla faixa de pressão parcial de oxigênio [9].

O La1-x $\operatorname{Sr}_{x} \mathrm{Ga}_{1-y} \mathrm{Mg}_{\mathrm{y}} \mathrm{O}_{3+\delta}[\delta=(\mathrm{x}+\mathrm{y}) / 2]$, conhecido pela sigla LSGM, apresenta alta condutividade iônica em amplas faixas de temperatura e pressão parcial de oxigênio. A $800 \stackrel{\circ}{\circ}$, por exemplo, o número de transporte iônico é igual a 1 na faixa de pressão parcial de oxigênio que vai de 0,4 até $10^{-20} \mathrm{~atm}[8,20]$.

\subsection{LSGM - Revisão da Literatura}

Será apresentada, a seguir, uma revisão bibliográfica relacionada aos estudos de diversas propriedades do $\mathrm{La}_{1-x} \mathrm{Sr}_{x} \mathrm{Ga}_{1-y} \mathrm{Mg}_{y} \mathrm{O}_{3+\delta}$ preparado pelo método de mistura de óxidos e as opções de técnicas de síntese empregadas para este material.

Um dos métodos mais citados na literatura para a preparação do LSGM é por meio da mistura dos óxidos/carbonatos como reagentes, seguido de reação em estado sólido a altas temperaturas.

- Teores de $\mathrm{Mg}$ e Sr

Inicialmente as pesquisas concentraram-se no estudo da solubilidade do $\mathrm{Sr}$ e $\mathrm{Mg}$ no galato de lantânio e sua influência nas propriedades elétricas quando comparado com outros materiais utilizados como eletrólitos sólidos 
[21]. Posteriormente, foi mostrado que o limite de solubilidade do $\mathrm{Mg}$ é $40 \% \mathrm{em}$ mol e o aumento da quantidade de $\mathrm{Mg}$ favorece a formação da fase $\mathrm{LaSrGaO}_{4}$ [22]. Além disso, na dupla dopagem de $\mathrm{Sr}$ e $\mathrm{Mg}$ a fase $\mathrm{LaSrGa}_{3} \mathrm{O}_{7}$ é detectada e fixando a quantidade de $\mathrm{Mg}$ e aumentando a quantidade de $\mathrm{Sr}$, ou fixando a quantidade de $\mathrm{Sr}$ e aumentando a quantidade de $\mathrm{Mg}$, aumenta-se as fases secundárias [23]. A introdução de $\mathrm{Mg}$ favorece a solubilidade do SrO [24]. $\mathrm{O}$ excesso de até $10 \%$ de $M g$ no sitio do Ga não prejudica a condutividade do $\mathrm{La} 0,8_{0} \mathrm{Sr}_{0,2} \mathrm{Ga}_{0,83} \mathrm{Mg}_{0,17+2} \mathrm{O}_{3+\delta}$ [25]. Um estudo com 27 composições de LSGM mostrou que em tempos longos de sinterização a densidade aumenta, alcança um máximo e depois diminui. A condutividade iônica também aumenta com 0 aumento da quantidade de $\mathrm{Sr}$ e Mg e após alcançar um valor máximo, diminui. Os maiores valores de condutividade iônica foram obtidos para $\mathrm{La} 0,85 \mathrm{Sr}_{0,15} \mathrm{Ga}_{0,8} \mathrm{Mg}_{0,2} \mathrm{O}_{3}$ e $\mathrm{La} 0,8 \mathrm{Sr}_{0,2} \mathrm{Ga}_{0,85} \mathrm{Mg}_{0,15} \mathrm{O}_{3}$ [26].

\section{- Testes em células a combustível}

Diversos trabalhos, antes mesmo do completo entendimento sobre a estrutura do LSGM, mostraram resultados de testes em células a combustível de óxido sólido utilizando o LSGM como eletrólito. Estes trabalhos mostraram que o LSGM possui alta condutividade iônica em temperaturas intermediárias. Além disso, também foi reportado boa estabilidade química do LSGM em uma ampla faixa de pressão parcial de oxigênio. O LSGM é estável em atmosferas redutora, oxidante e de $\mathrm{CO}_{2}$. Uma camada intermediária entre o eletrólito e o anodo é necessária para evitar a reação entre $\mathrm{NiO}$ e LSGM formando $\mathrm{LaNiO}_{3}$. Também foi estudado a reatividade do LSGM com materiais do anodo e catodo [27-38].

\section{- Estrutura cristalina}

M. Feng e J. B. Goodenough [9] reportaram uma estrutura cúbica para $\mathrm{La}_{0,9} \mathrm{Sr}_{0,1} \mathrm{Ga}_{0,8} \mathrm{Mg}_{0,2} \mathrm{O}_{2,85} \mathrm{em}$ temperatura ambiente, enquanto $\mathrm{T}$. Ishihara e colaboradores [8] descreveram o $\mathrm{LaGaO}_{3}$ e $\mathrm{La}_{0,9} \mathrm{Sr}_{0,1} \mathrm{Ga}_{0,8} \mathrm{Mg}_{0,2} \mathrm{O}_{2,85}$ com estrutura ortorrômbica. J. Drennan e colaboradores [39] utilizando difração de 
raios $\mathrm{X}$, microscopia eletrônica de varredura e transmissão, mostraram que a composição Lao,9 $\mathrm{Sr}_{0,1} \mathrm{Ga}_{0,8} \mathrm{Mg}_{0,2} \mathrm{O}_{3-\delta}$ possui estrutura ortorrômbica, grupo espacial Pnma, e sofre uma transição de fase em $172{ }^{\circ} \mathrm{C}$ para romboédrica.

Utilizando difração de nêutrons de alta temperatura, foi reportado que o $\mathrm{LaGaO}_{3}$ possui estrutura ortorrômbica em temperatura ambiente e romboédrica entre 250 e $1000^{\circ} \mathrm{C}$. A estrutura do $\mathrm{La}_{0,9} \mathrm{Sr}_{0,1} \mathrm{Ga}_{0,8} \mathrm{Mgg}_{0,2} \mathrm{O}_{2,85}$ é monoclínica e ocorre duas transições de fases entre 250 e $1000{ }^{\circ} \mathrm{C}$ : monoclínica (pseudoortorrômbica) - monoclínica (pseudo-romboédrica) - romboédrica. Essa diferença na estrutura pode estar associada ao fato que o desvio de simetria ortorrômbica é relativamente pequeno comparado à monoclínica [40].

A. Skowron e colaboradores [41] estudaram o $\mathrm{La}_{0,8} \mathrm{Sr}_{0,2} \mathrm{Gaa}_{0,85} \mathrm{Mgg}_{0,15} \mathrm{O}_{2,85}$ por difração de nêutrons e microscopia eletrônica de transmissão em temperatura ambiente e alta temperatura. A difração de nêutrons revelou uma estrutura cúbica, mas a difração de elétrons mostrou a presença de microdomínios com simetria menor que a cúbica, provavelmente associados com as estruturas romboédrica e monoclínica, enquanto K. Huang reportou que a composição $\mathrm{La}_{0,8} \mathrm{Sr}_{0,2} \mathrm{Ga}_{0,83} \mathrm{Mg}_{0,17} \mathrm{O}_{2,815}$ possui fase cúbica [42].

M. Lerch e colaboradores [43] utilizando difração de nêutrons em temperatura ambiente, 800 e $1000{ }^{\circ} \mathrm{C}$ reportaram que em $25{ }^{\circ} \mathrm{C}$ o $\mathrm{LaGaO}_{3}$ possui estrutura perovsquita distorcida ortorrômbica (Pnma) e 0 $\mathrm{La}_{0,9} \mathrm{Sr}_{0,1} \mathrm{Ga}_{0,8} \mathrm{Mg}_{0,2} \mathrm{O}_{2,85}$ possui estrutura perovsquita distorcida ortorrômbica (Imma). Em altas temperaturas, $\mathrm{o} \mathrm{LaGaO}_{3}$ apresenta estrutura romboédrica $(R \overline{3} C)$ e o La0,9Sro, $\mathrm{Ga}_{0,8} \mathrm{Mg}_{0,2} \mathrm{O}_{2,85}$ estrutura ortorrômbica (Pm3m).

L. Vasylechko e colaboradores [44] estudaram a estrutura cristalina de La1-x $\operatorname{Sr}_{x} \mathrm{Gaa}_{1-2 x} \mathrm{Mgg}_{2 x} \mathrm{O}_{3-y}(\mathrm{x}=0,05$ e 0,1$)$ utilizando difração de raios $\mathrm{X}$ de alta resolução. Na temperatura ambiente o cristal com $x=0,05$ possui estrutura ortorrômbica (Imma) e com $x=0,1$ possui estrutura monoclínica (12/a). As medidas indicam duas transições de fase para La0,95 $\mathrm{Sr}_{0,05} \mathrm{Ga}_{0,9} \mathrm{Mgg}_{0,1} \mathrm{O}_{2,92}$ ( 247$\left.29{ }^{\circ} \mathrm{C}\right)$ e três transições de fase para Lao,9Sro, $\mathrm{Gao}, 8_{0,8} \mathrm{Mg}_{0,2} \mathrm{O}_{2,85}(497,597-697$ $\left.{ }^{\circ} \mathrm{C}\right)$.

Utilizando espectroscopia Raman foi observado que $\mathrm{LaGa} 0,8 \mathrm{Mg}_{0,2} \mathrm{O}_{2,9}$ e $\mathrm{La} 0,9 \mathrm{Sr} 0,1 \mathrm{Ga}_{0,9} \mathrm{Mgg}_{0,1} \mathrm{O}_{2,9}$ possuem estrutura romboédrica e $\mathrm{La}_{0,8} \mathrm{Sr}_{0,2} \mathrm{GaO}_{2,9}$ possui estrutura ortorrômbica [45]. 
P. Datta e colaboradores [46] mostraram que a simetria depende da quantidade de aditivos no $\mathrm{La}_{1-x} \mathrm{Sr}_{y} \mathrm{Ga}_{y} \mathrm{Mg}_{1-y} \mathrm{O}_{3-\delta}$. $\mathrm{Em} \mathrm{x}+\mathrm{y} \leq 0,25$ a estrutura é ortorrômbica, $0,25<x+y \leq 0,30$ a simetria é ortorrômbica e romboédrica e $x+y \geq$ 0,35 a simetria é cúbica. Quando $\mathrm{x}+\mathrm{y}>0,35$ a condutividade é de aproximadamente $0,164-0,173 \mathrm{~S} . \mathrm{cm}^{-1}$ [47]. Resultado similar foi observado por Rozumek e colaboradores [48], que reportaram que pequenas quantidades de estrôncio e magnésio promovem simetria ortorrômbica e quantidades maiores de estrôncio e magnésio promovem simetria romboédrica ou cúbica. A partir dos resultados obtidos os autores construíram um diagrama de fase que mostra as modificações da estrutura do LSGM sinterizadas a $1500{ }^{\circ} \mathrm{C}$, Figura 3.

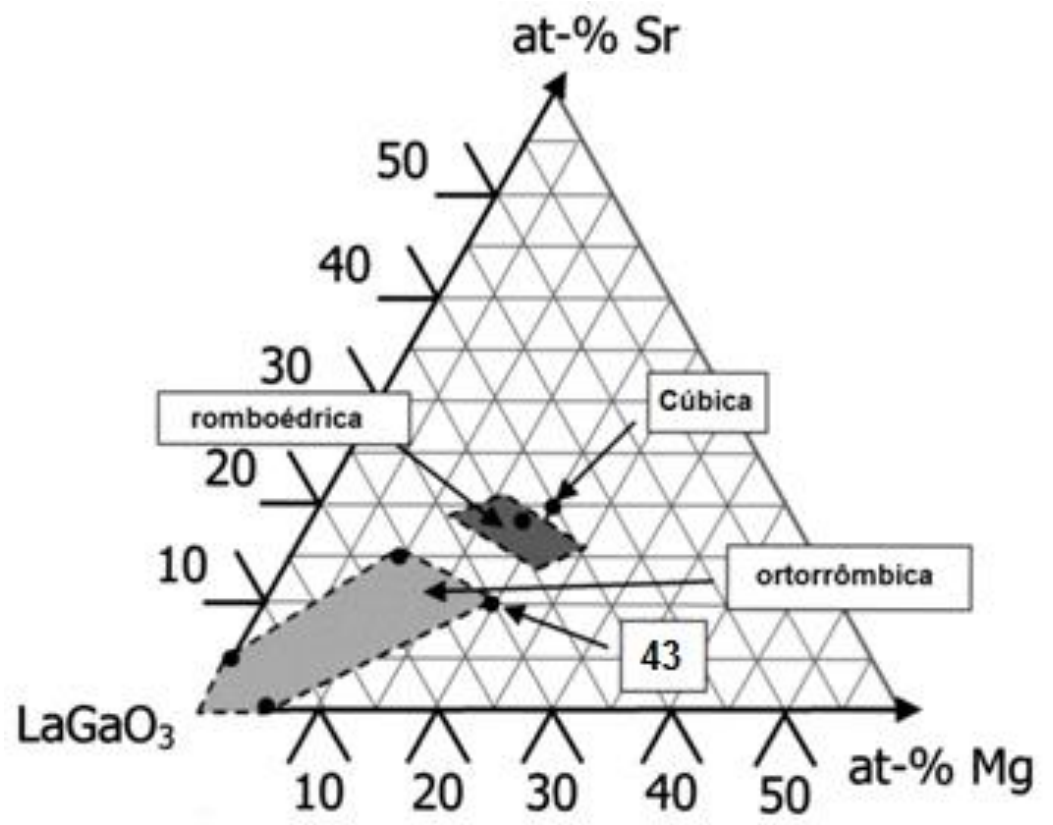

Figura 3: Diagrama de fase do LSGM sinterizado a $1500{ }^{\circ} \mathrm{C}$ [48].

As discordâncias descritas com relação à estrutura cristalina ocorrem devido ao LSGM possuir uma leve distorção da estrutura perovsquita. É muito difícil distinguir entre diferentes tipos de estruturas do tipo perovsquita ligeiramente distorcidas por difração de raios $X$ convencional. Difração de raios $X$ de alta resolução com elevada relação sinal-ruído são necessários para detectar pequenas deformações na estrutura ou utilizar difração de nêutrons para a determinação da fase do sistema La-Ga-Sr-Mg-O. 


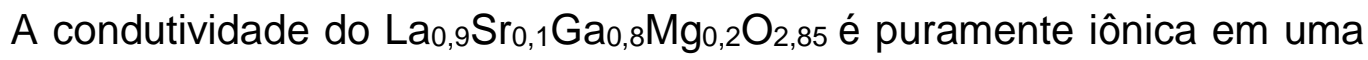
ampla faixa de pressão parcial de oxigênio [32]. Além disso, a condutividade iônica do $\mathrm{La}_{1-\mathrm{x}} \mathrm{Sry}_{y} \mathrm{Gay}_{y} \mathrm{Mg}_{1-\mathrm{y}} \mathrm{O}_{3-\delta}$ é superior à de materiais como $\mathrm{LaAlO}_{3}, \mathrm{LaScO}_{3}$ e LalnO ${ }_{3}$ com $0,1 \mathrm{Sr}$ no sítio $\mathrm{A}$ e $0,1 \mathrm{Mg}$ no sítio $\mathrm{B}$ [24,49]. M. Li e colaboradores [50] reportaram que a condutividade iônica do $\mathrm{La}_{0,9} \mathrm{Sr}_{0,1} \mathrm{Gaa}_{0,8} \mathrm{Mg}_{0,2} \mathrm{O}_{3-\delta}$ é de 0,$04 ; 0,06$ e 0,08 S.cm ${ }^{-1}$ a 700, 750 e $800{ }^{\circ} \mathrm{C}$.

M. Kurumada e colaboradores [51] investigaram a condutividade elétrica do $\mathrm{La}_{0,9} \mathrm{Sr}_{0,1} \mathrm{GaO}_{3-\delta}$ e $\mathrm{La}_{0,9} \mathrm{Sr}_{0,1} \mathrm{Gaa}_{0,8} \mathrm{Mg}_{0,2} \mathrm{O}_{3-\delta}$. A energia de ativação para a migração dos íons $\mathrm{O}^{2-}$ dentro dos grãos aumenta com o aumento da quantidade de $\mathrm{Mg}$, que tem um efeito adverso na condutividade iônica, mas o excesso de vacâncias de oxigênio compensa esse efeito. Nos contornos de grão, a energia de ativação para migração diminui levemente, mas a energia de ativação necessária para criar vacâncias de oxigênio livres não muda. LSGM com estrutura romboédrica apresenta condutividade iônica maior do que com estrutura ortorrômbica [45]. Maiores valores de condutividade iônica foram obtidos para as composições $\mathrm{La}_{0,85} \mathrm{Sr}_{0,15} \mathrm{Ga}_{0,8} \mathrm{Mgg}_{0,2} \mathrm{O}_{3}$ e $\mathrm{La}_{0,8} \mathrm{Sr}_{0,2} \mathrm{Ga}_{0,85} \mathrm{Mg}_{0,15} \mathrm{O}_{3}$ [26].

A Tabela I mostra condições de sinterização, os valores de condutividade iônica e densidade relativa da composição $\mathrm{La}_{0,9} \mathrm{Sr}_{0,1} \mathrm{Ga}_{0,8} \mathrm{Mg}_{0,2} \mathrm{O}_{3-8}$ a $600{ }^{\circ} \mathrm{C}$, encontrados na literatura.

Tabela I: Condições de sinterização para o LSGM preparado por diferentes métodos, valores de condutividade iônica $(\sigma)$ a $600 \stackrel{\circ}{C}$ e densidade relativa.

\begin{tabular}{ccccc}
\hline \hline Método & $\begin{array}{c}\text { Condições } \\
\left({ }^{\circ} \mathbf{C} / \mathbf{h}\right)\end{array}$ & $\left.\sigma(\mathbf{S . c m})^{-1}\right)$ & $\begin{array}{c}\text { Densidade } \\
\text { relativa } \\
(\%)\end{array}$ & Referência \\
\hline \hline Mistura de óxidos & $1400 / 6$ & 0,007 & 75 & 52 \\
Mistura de óxidos & $1500 / 6$ & 0,019 & 96,9 & 52 \\
Mistura de óxidos & $1600 / 6-1400 / 4$ & 0,015 & 98 & 50 \\
Mistura de óxidos & $1500 / 24$ & 0,017 & 97,5 & 26 \\
Sol-gel & $1350 / 36$ & 0,014 & --- & 53 \\
Mistura de óxidos & $1470 / 24$ & 0,018 & -- & 42 \\
Sol-gel & $1400 / 12$ & 0,0063 & 93 & 54 \\
\hline \hline
\end{tabular}


Com o objetivo de aumentar a condutividade iônica do LSGM, substituições parciais adicionais têm sido relatadas, principalmente relacionadas com a introdução de metais de transição. A introdução de $\mathrm{Fe}$ e Co no sítio $B$ do $\mathrm{La}_{0,9} \mathrm{Sr}_{0,1} \mathrm{Ga}_{0,8} \mathrm{Mg}_{0,2} \mathrm{O}_{2,85}$ e de até $1 \%$ em mol de Co aumenta a condutividade iônica e teores maiores de Co e Fe tornam o LSGM um condutor misto $[55,56]$. Na composição $\mathrm{La}_{0,8} \mathrm{Sr}_{0,2} \mathrm{Ga}_{0,8} \mathrm{Mg}_{0,2} \mathrm{O}_{3}$ contendo cobalto no sítio do $\mathrm{Ga}$, o aditivo mostrou ser efetivo para aumentar a condutividade iônica. Entretanto, quantidade maior que $10 \%$ em mol possui condutividade mista [57]. Outro estudo mostrou que a adição de $\mathrm{Nd}, \mathrm{Sm}, \mathrm{Gd}, \mathrm{Y}$ ou $\mathrm{Yb}$ na rede do La diminui a condutividade elétrica do LSGM [26].

A condutividade iônica do $\mathrm{La}_{1-x} \mathrm{Sr}_{x} \mathrm{Ga}_{0,8-y} \mathrm{MgM}_{0,2} \mathrm{O}_{3-\delta}$ ( $\mathrm{x}=0-0,20, y=0,15-$ $0,20)$ com $\mathrm{M}=\mathrm{Fe}$, Co, Ni é inferior à do $\mathrm{La}_{1-x} \mathrm{Sr}_{x} \mathrm{Ga}_{y} \mathrm{Mg}_{1-y} \mathrm{O}_{3-\delta}$. Foi também verificado que a condutividade iônica aumenta na sequência $\mathrm{M}=\mathrm{Co}<\mathrm{Fe}<\mathrm{Ni}$ [58].

- Fases secundárias

Estudos sistemáticos sobre a importância e influência das fases secundárias no LSGM mostram que a fase $\mathrm{LaSrGa}_{3} \mathrm{O}_{7}$ é uma fase isolante, e a fase $\mathrm{LaSrGaO}_{4}$ forma fase líquida durante a sinterização aumentando o contato entre os contornos de grãos e diminuindo a contribuição dos contornos de grãos para a resistividade elétrica [42]. A quantidade de fases secundárias aumenta em atmosferas oxidantes. Sob condições redutoras, não foram encontrados temperatura e tempo adequados para obter LSGM com fase única [11]. O aumento de $\mathrm{Sr}$ na rede do $\mathrm{La}$ e $\mathrm{Mg}$ na rede do Ga favorece a formação das fases secundárias $\mathrm{SrLaGa}_{3} \mathrm{O}_{7}$ e $\mathrm{La}_{4} \mathrm{Ga}_{2} \mathrm{O}_{9}$, respectivamente [59].

A fase $\mathrm{La}_{1+x} \mathrm{Sr}_{1-x} \mathrm{Ga}_{3} \mathrm{O}_{7-\delta}$ rica em La possui condutividade iônica similar ao LSGM, enquanto que as fases $\mathrm{La}_{4} \mathrm{Ga}_{2} \mathrm{O}_{9}$ e $\mathrm{LaSrGaO}_{4}$, possuem valores de condutividade menor que o LSGM $\left(10^{-5}\right.$ a $10^{-3}{\mathrm{~S} . \mathrm{cm}^{-1}}^{-1}$ a $800^{\circ} \mathrm{C}[60]$.

E. Djurado e M. Labeau [11] prepararam o LSGM por reação em estado sólido e pirólise por aspersão (spray pirólise) e mostraram que um tratamento térmico de $1500{ }^{\circ} \mathrm{C} / 6 \mathrm{~h}$ é necessário para obter uma quantidade menor de 
fases secundárias. Além disso, o aumento do tempo de sinterização para $48 \mathrm{~h}$ favorece a formação de fases secundárias.

\section{- Outros estudos}

Outras propriedades tais como mecânicas e expansão térmica também têm sido estudadas para o LSGM.

A deformação do $\mathrm{La} 0,8 \mathrm{Sr}_{0,2} \mathrm{Ga}_{0,85} \mathrm{Mgg}_{0,15} \mathrm{O}_{2,85}$ é controlada pelas vacâncias dos cátions La ou Ga. A taxa de difusão das espécies calculadas para a deformação são menores do que a difusão do oxigênio na rede. $O$ defeito que controla a deformação do LSGM são as vacâncias de gálio [61, 62].

H. Hayashi e colaboradores [63] estudaram os efeitos das quantidades de estrôncio e magnésio na expansão térmica do LSGM. Outros autores [44], reportaram que a substituição do La por $\mathrm{Sr}$ aumenta levemente a expansão térmica do $\mathrm{La}_{1-x} \mathrm{Sr}_{x} \mathrm{Ga}_{1-2 \times} \mathrm{Mg}_{2 \times} \mathrm{O}_{3-y}[44]$.

Atualmente as pesquisas estão concentradas no desenvolvimento de um método de síntese ou no aprimoramento daqueles já existentes, tal que permitam obter o LSGM livre de fases secundárias ou que o teor destas seja minimizado, além da obtenção de uma microestrutura homogênea, com alta densidade.

- Método sol-gel

O primeiro trabalho utilizando um método químico para obter o LSGM foi proposto por K. Huang e colaboradores [46] utilizando o método sol-gel para Lao,9Sro, $1 \mathrm{Ga}_{0,8} \mathrm{Mg}_{0,2} \mathrm{O}_{2,85}$. Foi obtido o composto com fase cúbica e com $93 \%$ da densidade teórica, após sinterização em $1370{ }^{\circ} \mathrm{C} / 36 \mathrm{~h}$ e a condutividade de 0,11 S.cm ${ }^{-1}$ a $800^{\circ} \mathrm{C}$.

O $\mathrm{LaGaO}_{3}$ e $\mathrm{La}_{0,9} \mathrm{Sr}_{0,1} \mathrm{Ga}_{0,8} \mathrm{Mg}_{0,2} \mathrm{O}_{2,85}$ preparados pelo método sol-gel foram estudados por difração de nêutrons na temperatura de $25{ }^{\circ} \mathrm{C}$. Os resultados mostraram que estes possuem estrutura ortorrômbica Pnma e 
Imma, respectivamente e, altas temperaturas resultam em uma estrutura romboédrica $R \overline{3} C$ e $P m 3 m$, respectivamente [43].

J. Cheng e A. Navrotsky [64] prepararam o La1-x $\mathrm{Sr}_{x} \mathrm{Gaa}_{1-y} \mathrm{Mg}_{y} \mathrm{O}_{3-\delta}$, $\mathrm{La}_{1-x \mathrm{~B}} \mathrm{Ba}_{x} \mathrm{Ga}_{1-y} \mathrm{Mg}_{y} \mathrm{O}_{3-\delta}$ e $\mathrm{LaGa}_{1-y} \mathrm{Mg}_{y} \mathrm{O}_{3-\delta}$, pelos métodos de reação em estado sólido e pelo método sol-gel e estudaram as propriedades termodinâmicas. Esses materiais tornam-se menos exotérmicos com o aumento da dopagem sugerindo um efeito de desestabilização das vacâncias de oxigênio. A entalpia endotérmica de formação de vacâncias é $275 \pm 37,166 \pm 18$ e $138 \pm 12 \mathrm{~kJ} / \mathrm{mol}$. Em termos energéticos o Sr é o melhor aditivo no sítio do La e o Mg no sítio do Ga.

F. Weiyan e colaboradores [54] prepararam o $\left(\mathrm{La}_{0,9} \mathrm{Sr}_{0,2}\right) \times \mathrm{Ga}_{0,8} \mathrm{Mgo}_{0,2} \mathrm{O}_{3}$ com $x=0,97 ; 1,00$ e 1,03 pelo método sol-gel com estrutura ortorrômbica e pequenas quantidades de fases secundárias. A não estequiometria no sítio $A$ influencia o tamanho médio de grão. As maiores condutividades foram obtidas para $x=1,03$.

A introdução de metais de Co e Ni no sitio do Ga para a composição $\mathrm{La} 0,85 \mathrm{Sr}_{0,15} \mathrm{Ga}_{0,8} \mathrm{Mgg}_{0,2-x} \mathrm{M}_{\times} \mathrm{O}_{2,825}$ preparado pelo método sol-gel e sinterizado a $1450{ }^{\circ} \mathrm{C} / 2 \mathrm{~h}$ possui estrutura ortorrômbica. Os resultados mostraram que a introdução de $5 \%$ em mol de Co promove formação de fases secundárias, além de promover a diminuição da condutividade [65].

\section{- Método de Combustão}

Um método amplamente utilizado para obter o LSGM é o de combustão. J. W. Stevenson e colaboradores $[66,67]$ prepararam o LSGM pelo método de combustão utilizando glicina. $\mathrm{La} 0,9 \mathrm{Sr}_{0,1} \mathrm{Ga}_{0,8} \mathrm{Mg}_{0,2} \mathrm{O}_{2,85}$ foi obtido com densidade de $97 \%$ e pequena quantidade de fases secundárias comparado com as demais composições estudadas. O coeficiente de expansão térmica é maior para materiais à base galato de lantânio do que para YSZ. Temperaturas elevadas provocaram o inchaço das amostras, que possivelmente está associado à volatização do $\mathrm{Ga}_{2} \mathrm{O}$ da estrutura, que foi verificado por espectrometria de massa. Também mostraram que a estrutura perovsquita somente tolera uma quantidade limitada de deficiência catiônica do sítio A na 
rede antes da formação de fases secundárias. A condutividade elétrica tende a diminuir com o aumento da razão não estequiométrica dos cátions $A / B$. Sob condições oxidantes, a condutividade foi praticamente iônica, mas em atmosferas redutoras uma substancial condutividade eletrônica foi observada. É provável que a condutividade eletrônica resulte da introdução de portadores de carga eletrônicos devido à redução do $\mathrm{Ga}^{3+}$ para $\mathrm{Ga}^{2+}[66,67]$.

A síntese do $\mathrm{La}_{0,8} \mathrm{Sr}_{0,2} \mathrm{Ga}_{0,85} \mathrm{Mg}_{0,15} \mathrm{O}_{3-8}$ utilizando o método de combustão com glicina permitiu a diminuição da temperatura de sinterização de $100{ }^{\circ} \mathrm{C}$ menor do que pelo método de mistura de óxidos. A contribuição do contorno de grão para a condutividade do LSGM sintetizado por este método é menor, indicando que o método de combustão utilizando glicina diminui a formação de fases secundárias [68].

P. Majewski e colaboradores [69] prepararam o $\mathrm{La}_{0,8} \mathrm{Sr}_{0,2} \mathrm{Ga}_{0,8} \mathrm{Mgg}_{0,2} \mathrm{O}_{3}$ pelos métodos de mistura de óxidos, combustão utilizando glicina e Pechini. Os métodos químicos proporcionaram amostras com tamanho de grãos menores e densidades inferiores ao método de mistura de óxidos. Não foi possível obter LSGM com fase única na temperatura de $1400{ }^{\circ} \mathrm{C}$. Resultado similar foi obtido para $\mathrm{La}_{0,9} \mathrm{Sr}_{0,1} \mathrm{Gaa}_{0,8} \mathrm{Mg}_{0,2} \mathrm{O}_{2,85}$ sinterizado a $1300{ }^{\circ} \mathrm{C} / 5 \mathrm{~h}$ por combustão com poliacrilamida [70].

A síntese do Lao,85 $\mathrm{Sr}_{0,15} \mathrm{Ga}_{0,8} \mathrm{Mgo}_{2} \mathrm{O}_{2,85}$ pelo método de combustão utilizando glicina e pelo método de combustão utilizando EDTA (ácido etilenodiaminotetracético) possibilitou obter valores de condutividade elétrica de 0,053 e $0,060{\mathrm{~S} . \mathrm{cm}^{-1}}^{-1} 800^{\circ} \mathrm{C}$, respectivamente [71].

T. Mathews e J. R. Sellar [72] sintetizaram o LSGM utilizaram o método de combustão com uréia e mostraram, por difração de nêutrons, a existência de microdomínios na matriz cúbica. Fase cúbica no LSGM foi encontrada apenas em elevadas temperaturas e altos teores de $\mathrm{Sr}$ e Mg [73].

$\mathrm{S}$. Bu Ha e colaboradores [74] utilizaram o método de glicina e estudaram os efeitos de aditivos no comportamento da sinterização e propriedades elétricas do $\mathrm{La}_{0,8} \mathrm{Sr}_{0,2} \mathrm{Gaa}_{0,8} \mathrm{Mg}_{0,2} \mathrm{O}_{2,8}$. A adição de $\mathrm{V}, \mathrm{Zn}, \mathrm{Si}$, Co ou Fe aumentou a densificação, a pureza da fase e a condutividade elétrica. Dentre esses cátions o V apresentou os melhores resultados. Posteriormente, os autores estudaram os efeitos da adição de $\mathrm{V}_{2} \mathrm{O}_{5}$ na temperatura de 
sinterização e condutividade elétrica do LSGM. Amostras de LSGM com 1\% em mol de $\mathrm{V}_{2} \mathrm{O}_{5}$ sinterizado a $1300{ }^{\circ} \mathrm{C}$ apresentaram condutividade de 0,027 S.cm ${ }^{-1} \mathrm{em} 700^{\circ} \mathrm{C}$ sob uma ampla faixa de pressão parcial de oxigênio [75].

\section{- Método de Pechini}

Outro método amplamente utilizado para o LSGM é o método Pechini. O. Schulz e colaboradores, utilizando o método Pechini para produzir o La0,8 $\mathrm{Sro}_{0,2} \mathrm{Ga}_{0,8} \mathrm{Mg}_{0,2} \mathrm{O}_{2,8}$, obtiveram o LSGM com fase única na temperatura de $1400{ }^{\circ} \mathrm{C}$. A difusão do gálio foi estudada utilizando um radiotraçador. O coeficiente de difusão para o gálio foi de $3 \times 10^{-13} \mathrm{~cm}^{2} \cdot \mathrm{s}^{-1}$ [76]. M. Shi e colaboradores [77] utilizaram o método Pechini, sol-gel e reação em estado sólido para sintetizar $\mathrm{La} 0,85 \mathrm{Sro}, 15 \mathrm{Ga}_{0,8} \mathrm{Mgg}_{0,2} \mathrm{O}_{2,825}$. Os autores mostram que para esta composição de LSGM preparada pelo método Pechini possui menor quantidade de fases secundárias quando comparada com as amostras preparadas pelo método sol-gel e reação em estado sólido na mesma composição.

O LaGaO 3 e o Lao,9 $\mathrm{Sr}_{0,1} \mathrm{GaO}_{2,95}$ preparado pelo método Pechini possuem fase única quando calcinados a 850 e $1340{ }^{\circ} \mathrm{C}$, respectivamente e $\mathrm{O}$ $\mathrm{La} 0,8 \mathrm{Sr}_{0,2} \mathrm{Ga}_{0,89} \mathrm{Mg}_{0,17 \mathrm{O}_{2,815}}$ possui as fases $\mathrm{LaSrGa}_{3} \mathrm{O}_{7}$ e $\mathrm{LaSrGaO}_{4}$ mesmo após calcinação a $1400^{\circ} \mathrm{C} / 8 \mathrm{~h}$ [78].

E. Polini e colaboradores [79] sintetizaram o LSGM pelos métodos Pechini e por complexação de cátions. Pós com fase única não foram obtidos mesmo com calcinações a $1500{ }^{\circ} \mathrm{C} / 10 \mathrm{~h}$. Segregações de $\mathrm{MgO}$ não detectadas por difração de raios $\mathrm{X}$, foram observadas por microscopia eletrônica de varredura. Essa fase prejudicou a condutividade iônica. O LSGM obtido pelo método de complexação de cátions apresentou melhor condutividade do que o preparado pelo método Pechini. 
- Método de Coprecipitação

A síntese do $\mathrm{La}_{0,8} \mathrm{Sr}_{0,2} \mathrm{Ga}_{0,8} \mathrm{Mg}_{0,2} \mathrm{O}_{2,8}$ pelo método de coprecipitação permitiu obter amostras com condutividade elétrica total a $600{ }^{\circ} \mathrm{C}$ de 0,014 $\mathrm{S} / \mathrm{cm}$. As energias de ativação do processo de condução obtidas para o grão, contorno de grão e total foram 1,02; 1,05 e 1,03 eV, respectivamente [80]. Resultado similar foi obtido utilizando o mesmo método para a composição $\mathrm{La}_{0,8} \mathrm{Sr}_{0,2} \mathrm{Ga}_{0,9} \mathrm{Mg}_{0,1} \mathrm{O}_{2,85}$, com condutividade total de 0,011 e $0,064 \mathrm{~S} / \mathrm{cm}$ a 600 e $800{ }^{\circ} \mathrm{C}$, respectivamente, com densidade relativa de $98 \%$ [81].

T-Y. Chen e K-Z. Fung [82] prepararam pós nanométricos de LSGM pelo método de precipitação seguido de tratamento hidrotermal com ureia. A condutividade elétrica do LSGM foi de $0,056{\mathrm{~S} . \mathrm{cm}^{-1}}^{-1} 800{ }^{\circ} \mathrm{C}$, melhor do que aquela obtida para o LSGM preparado por reação em estado sólido $(0,035$ $\left.\mathrm{S} . \mathrm{cm}^{-1}\right)$, na mesma temperatura.

\section{- Outros métodos de síntese}

C. Oncel e colaboradores [83] prepararam o La1-x $\mathrm{Sr}_{x} \mathrm{Ga}_{1-y} \mathrm{Mg}_{y} \mathrm{O}_{3-\delta} \mathrm{com}$ $\mathrm{x}=0,1$ e $\mathrm{y}=0,15$ e 0,17 pelo método dos precursores orgânicos usando ácido tartárico. Amostras sinterizadas em $1450^{\circ} \mathrm{C} / 6 \mathrm{~h}$ apresentaram-se com fase única por difração de raios $\mathrm{X}$, mas análise por microscopia eletrônica mostrou a existência de precipitados de $\mathrm{MgO}$.

J. Weitkamp, e H-D. Wiemhofer [84] prepararam pelo método de liofilização o $\mathrm{La}_{0,8} \mathrm{Sr}_{0,2} \mathrm{Ga}_{1-y} \mathrm{Mgy}_{\mathrm{y}} \mathrm{O}_{3-\delta} \mathrm{com} \quad \mathrm{y}=0,15$ e 0,2 e a composição ( $\left.\mathrm{La}_{0,8} \mathrm{Sr}_{0,2}\right) \mathrm{Ga}_{0,8} \mathrm{Mg}_{0,2} \mathrm{O}_{3-\delta}$ e utilizaram o método de polarização para estimar os valores da condutividade tipo $p$, que é meia ordem de grandeza maior que a da céria. A condutividade tipo $n$ desvia do modelo usual de defeitos e isso pode estar associado com a perda de $\mathrm{Ga}_{2} \mathrm{O}$ e/ou formação de ligas de $\mathrm{Pt}-\mathrm{Ga}$ sob condições redutoras.

K. Traina e colaboradores [85] utilizaram o método de liofilização e autoignição seguido de calcinação a $1200{ }^{\circ} \mathrm{C} / 1 \mathrm{~h}$ com elevada uniformidade evitando etapas de calcinações para obter $\mathrm{La} 0,9 \mathrm{Sr}{ }_{0,1} \mathrm{Ga}_{0,8} \mathrm{Mgg}_{0,2} \mathrm{O}_{2,85} \mathrm{com}$ densidade de $99 \%$ quando sinterizadas a $1450{ }^{\circ} \mathrm{C} / 6 \mathrm{~h}$. A condutividade elétrica 
em $800{ }^{\circ} \mathrm{C}$ foi de 0,11 S. $\mathrm{cm}^{-1}$. A composição $\mathrm{La}_{1-x} \mathrm{Sr}_{x} \mathrm{Ga}_{0,8} \mathrm{Mg}_{0,2} \mathrm{O}_{3-\delta}$ também foi preparada pelo método de liofilização e a condutividade dos grãos e contornos de grãos foram praticamente independentes da fração de fases secundárias [86].

A. Moure e colaboradores [13] mostraram que a formação da fase única em LSGM preparado por mecânicossíntese é possível em baixas temperaturas quando aumenta-se o tempo de mistura e a quantidade de $\mathrm{Mg}$. Além disso, a solubilidade do $\mathrm{Mg}$ e do $\mathrm{Sr}$ aumenta com o aumento do tempo de mistura. Para a composição $\mathrm{Sr}=0,20$ e $\mathrm{Mg}=0,15$, existe diferença na composição das fases secundárias entre a superfície e interior da cerâmica.

Raghvendra e colaboradores [87], utilizando o método do etileno glicol obtiveram $\mathrm{La}_{0,9} \mathrm{Sr}_{0,1} \mathrm{Ga}_{0,8} \mathrm{Mg}_{0,2} \mathrm{O}_{3-\delta} \mathrm{com}$ estrutura ortorrômbica e fase única quando sinterizado a $1400{ }^{\circ} \mathrm{C} / 6 \mathrm{~h}$ com condutividade de $0,056 \mathrm{~S}^{-\mathrm{cm}^{-1} \mathrm{em}}$ $800{ }^{\circ} \mathrm{C}$.

Shuai Li e B. Bergman [10] prepararam o LSGM pelo método de polimerização e estudaram o efeito da substituição de Sr e Mg na formação de fases secundárias, microestrutura e condutividade elétrica. A adição de $\mathrm{Sr}$ produziu mais fases secundárias ricas em $\mathrm{Sr}$, enquanto um aumento da solubilidade foi observada com a adição de Mg. A condutividade iônica aumentou com a substituição de Sr e Mg. A adição de Mg aumenta a energia de ativação. O $\mathrm{La}_{0,8} \mathrm{Sr}_{0,2} \mathrm{Ga}_{0,9} \mathrm{Mg}_{0,1} \mathrm{O}_{2,85}$ apresentou $\mathrm{O}$ melhor valor de condutividade iônica, de 0,128 S.cm ${ }^{-1}$ a $800{ }^{\circ} \mathrm{C}$. A composição

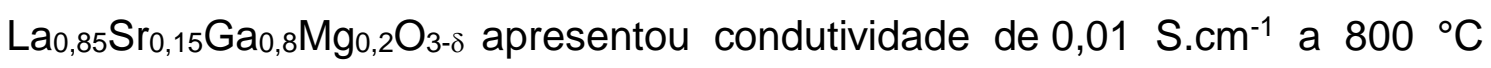
[88]. A composição $\mathrm{La}_{0,85} \mathrm{Sr}_{0,15} \mathrm{Ga}_{0,8} \mathrm{Mg}_{0,2} \mathrm{O}_{3-\delta}$ apresentou maior teor de fases secundárias, menor porosidade comparado com $\mathrm{La}_{0,9} \mathrm{Sr}_{0,1} \mathrm{Ga}_{0,8} \mathrm{Mg}_{0,2} \mathrm{O}_{3-\delta}$ e a correlação entre a condutividade iônica e a dureza do LSGM, mostrou ser um material com potencial para a aplicação em SOFC em temperaturas de 500$660^{\circ} \mathrm{C}[89]$.

Atenção especial tem sido dada mais recentemente à sinterização do LSGM. Liu e colaboradores [90] utilizaram a técnica de sinterização por descarga de plasma (spark plasma sintering) para a sinterização do $\mathrm{La}_{0,9} \mathrm{Sr}_{0,1} \mathrm{Ga}_{0,8} \mathrm{Mg}_{0,2} \mathrm{O}_{3-\delta}$ sintetizado pelo método da combustão. Observaram pequena fração de fases secundárias após sinterização a $1300^{\circ} \mathrm{C}$. As amostras 
com densidade relativa de $\sim 95 \%$ revelaram aumento na condutividade iônica em relação ao esperado.

Maglia e colaboradores [91] conseguiram reduzir a temperatura de sinterização do $\mathrm{La}_{0,9} \mathrm{Sr}_{0,1} \mathrm{Ga}_{0,8} \mathrm{Mgg}_{0,2} \mathrm{O}_{3-\delta}$ sintetizado pelo método dos precursores poliméricos para $850{ }^{\circ} \mathrm{C}$ com pressão de $700 \mathrm{MPa}$ utilizando também a sinterização por descarga de plasma. As amostras com elevada densidade apresentaram tamanho médio de grãos igual a $65 \mathrm{~nm}$. As caracterizações elétricas e estruturais mostraram que o LSGM obtido com pós nanométricos possui condutividade similar àqueles preparados por métodos convencionais. LSGM nanométrico e com densidades superiores a $90 \%$ foram obtidas utilizando o mesmo método de sinterização, para as amostras sintetizadas por precipitação e síntese hidrotermal [92].

J. Zhang e colaboradores [52] prepararam o LSGM por solidificação rápida a laser. O LSGM foi produzido em poucos segundos com densidade de $98 \%$ da densidade teórica. A condutividade obtida foi de 0,$027 ; 0,079$ e 0,134 S.cm ${ }^{-1}$ em 600, 700 e $800{ }^{\circ} \mathrm{C}$, respectivamente.

Y. Zhai e colaboradores prepararam o $\mathrm{La}_{0,8} \mathrm{Sr}_{0,2} \mathrm{Gaa}_{0,83} \mathrm{Mg}_{0,17} \mathrm{O}_{2,815}$ por síntese de polimerização induzida por microondas. Amostras sinterizadas a $1400{ }^{\circ} \mathrm{C} / 9 \mathrm{~h}$ apresentaram densidade de $6,19 \mathrm{~g} \cdot \mathrm{cm}^{-3}$ e tamanho de grão de 2-3 $\mu \mathrm{m}$ [93]. Os autores também reportaram sobre síntese por polimerização induzida por microondas com a mesma composição e sinterizadas nas mesmas condições com densidade de $6,45 \mathrm{~g} . \mathrm{cm}^{-3}$ [94]. Amostras com densidades de $92 \%$ sem fases secundárias foram obtidas utilizando o método sol-gel e sinterização por microondas a $1450{ }^{\circ} \mathrm{C} / 10 \mathrm{~h}$ para a composição $\mathrm{La}_{0,8} \mathrm{Sr}_{0,2} \mathrm{Ga}_{0,83} \mathrm{Mg}_{0,17} \mathrm{O}_{2,815}$ [95].

De forma geral, diversas propriedades do LSGM têm sido estudadas tanto dos materiais sintetizados utilizando o método convencional de mistura de óxidos quanto utilizando diversos métodos químicos. Entretanto, estudos adicionais que demonstrem as melhores condições de sinterização do LSGM, para obtenção de teor mínimo de fases secundárias, máxima densificação e máxima condutividade iônica são ainda necessários.

Neste trabalho, a composição escolhida foi $\mathrm{La}_{0,9} \mathrm{Sr}_{0,1} \mathrm{Gaa}_{0,8} \mathrm{Mg}_{0,2} \mathrm{O}_{3-\delta}$, por proporcionar materiais com menor teor de fases secundárias, quando 
comparada com as demais composições. Para obter o LSGM foi utilizado o método convencional de reação em estado sólido amplamente utilizado na literatura e o método de complexação de cátions, pouco utilizado para o LSGM, mas que apresenta diversas vantagens, descritas a seguir. Os pós obtidos pelos dois métodos empregados foram sinterizados utilizando dois métodos de sinterização: o método convencional e sinterização rápida (fast firing), descrito a seguir.

\subsection{Complexação de cátions}

Esta técnica foi proposta por P. Courty, B. Delmon, C. Marcilly e A. Sugier [96], para a produção de cerâmicas com aplicações como pigmentos, catalisadores etc. Nesta técnica não há limitação quanto ao número ou tipo de cátions a serem utilizados. Neste trabalho foi utilizado o ácido cítrico, pois este promove a cristalinidade do material [97]. Outros compostos orgânicos como os ácidos maleico, tartárico, glicólico ou láctico também podem ser utilizados como o agente complexante [97].

A eliminação do ácido cítrico ocorre de acordo com a reação I [98]:

$$
6 \mathrm{NO}_{3}{ }^{-}(\mathrm{aq})+\mathrm{C}_{6} \mathrm{H}_{8} \mathrm{O}_{7(\mathrm{aq})} \rightarrow 6 \mathrm{CO}_{2(\mathrm{~g})}+\mathrm{H}_{2} \mathrm{O}_{(\mathrm{g})}+6 \mathrm{OH}^{-}(\mathrm{qq})+6 \mathrm{NO}_{(\mathrm{g})}
$$

Segundo os autores, a complexidade da composição utilizada e a viscosidade elevada impedem a precipitação dos compostos. As soluções viscosas assim obtidas são bastante estáveis. Devido a sua estabilidade, a solução pode ser desidratada sem risco de ocorrer precipitação e/ou segregação dos cátions [98].

Na preparação do precursor é necessária que ocorra a desidratação rápida da solução a temperaturas não muito elevadas [99]. A desidratação produz inicialmente uma solução viscosa que depois se transforma em um sólido vítreo, amorfo e transparente que decompõe, com tratamento térmico, obtendo-se o óxido [96]. Para obter o óxido com composição homogênea, é necessário evitar a segregação das espécies metálicas presentes na solução. 
Assim a etapa de evaporação/concentração altera a viscosidade da solução, dificultando a formação de compostos cristalinos intermediários [96].

A última etapa do processo é a decomposição do precursor, que pode ser realizada em atmosfera controlada ou não, a uma temperatura superior a $200^{\circ} \mathrm{C}$ e, em particular, próxima de $600^{\circ} \mathrm{C}$. A condição essencial é que esteja no domínio de estabilidade ou de metaestabilidade dos óxidos produzidos [96].

Este método permite obter cerâmicas com elevadas densidades e partículas muito finas com dimensões entre 10 e 500 nm [96,98].

\subsection{Sinterização rápida}

A sinterização rápida (fast firing) tem sido empregada desde a década de 70 em cerâmicas avançadas [100,101], como um método para suprimir o crescimento de grãos, e ao mesmo tempo aumentar a densificação.

O método de sinterização rápida consiste em aquecer um compacto, a uma taxa elevada até uma determinada temperatura de patamar, no qual permanece por curto intervalo de tempo, em um forno pré-aquecido ou passar o compacto através de uma zona quente na temperatura de patamar. Em seguida o compacto é resfriado também rapidamente, mas de modo a não ocorrer um choque térmico. Taxas de aquecimento mais rápidas do que na sinterização convencional são empregadas neste método. A utilização de altas taxas de aquecimento favorece os mecanismos de transporte de massa associados à densificação do material. Portanto, a sinterização rápida promove, em geral, maior densificação com menor crescimento de grãos.

$\mathrm{Na}$ sinterização convencional estão presentes os fenômenos de convecção e radiação. Na sinterização rápida apenas o fenômeno de radiação está presente e como os coeficientes de radiação são maiores do que os de convecção promovem uma maior transferência de calor para a amostra.

A utilização das elevadas taxas de aquecimento promove também um gradiente de temperatura dentro das amostras, que pode causar densificação não uniforme. Assim, embora os tamanhos médios de grãos sejam menores na sinterização rápida, variações na microestrutura podem ser verificadas em diferentes micro regiões [102-105]. 
A sinterização rápida tem sido empregada em diversos materiais como alumina [100, 106-108], zircônia [109-110], céria [111], entre outros. Não foi encontrado na literatura trabalhos em que esta técnica foi utilizada para o galato de lantânio. 


\section{MATERIAIS E MÉTODOS}

A seguir serão apresentados os materiais e os métodos empregados para obtenção do LSGM. As condições experimentais das técnicas de caracterização utilizadas também serão reportadas.

\subsection{Materiais}

Os materiais utilizados na obtenção do LSGM pelos dois métodos de síntese estão listados na Tabela II.

Tabela II - Materiais de partida para a síntese do LSGM.

\begin{tabular}{|c|c|c|c|}
\hline Material & Fórmula & Fabricante & Pureza \\
\hline Óxido de lantânio & $\mathrm{La}_{2} \mathrm{O}_{3}$ & Alfa Aesar & $99,9 \%$ \\
\hline Óxido de gálio & $\mathrm{Ga}_{2} \mathrm{O}_{3}$ & Alfa Aesar & $99,99 \%$ \\
\hline Óxido de magnésio & $\mathrm{MgO}$ & Merk & P. A. \\
\hline Carbonato de estrôncio & $\mathrm{SrCO}_{3}$ & Vetec Quimica & P. A \\
\hline Nitrato de lantânio & 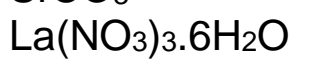 & Alfa Aesar & $99,99 \%$ \\
\hline Nitrato de gálio & $\mathrm{Ga}\left(\mathrm{NO}_{3}\right)_{3} \cdot \mathrm{xH}_{2} \mathrm{O}$ & Alfa Aesar & $99,99 \%$ \\
\hline Nitrato de magnésio & $\mathrm{Mg}\left(\mathrm{NO}_{3}\right)_{3} .6 \mathrm{H}_{2} \mathrm{O}$ & Vetec Química & P. A. \\
\hline Ácido cítrico & $\mathrm{C}_{6} \mathrm{H}_{8} \mathrm{O}_{7}$ & Synth & P. A. \\
\hline Ácido nítrico & $\mathrm{HNO}_{3}$ & Vetec Química & P. A. \\
\hline
\end{tabular}

\subsection{Métodos}

O LSGM foi sintetizado pelo método convencional de mistura de óxidos e pelo método de complexação de cátions.

\subsubsection{Mistura de óxidos}

Para obter a composição $\mathrm{La}_{0,9} \mathrm{Sr}_{0,1} \mathrm{Ga}_{0,8} \mathrm{Mg}_{0,2} \mathrm{O}_{3-\delta}$ pelo método de mistura de óxidos, os pós foram preparados a partir dos óxidos de $\mathrm{La}_{2} \mathrm{O}_{3}, \mathrm{Ga}_{2} \mathrm{O}_{3}, \mathrm{MgO}$ e $\mathrm{SrCO}_{3} . \mathrm{O} \mathrm{La}_{2} \mathrm{O}_{3}$ foi tratado termicamente a $1000 \stackrel{\circ}{\circ} \mathrm{C}$ por $3 \mathrm{~h}$ antes de ser utilizado. A Figura 4 mostra difratogramas de raios $\mathrm{X}$ para $\circ \mathrm{La}_{2} \mathrm{O}_{3}$ como recebido e após tratamento térmico. Os demais pós precursores foram utilizados como recebidos. Estes materiais foram mantidos em estufa a $100{ }^{\circ} \mathrm{C}$ para eliminação de água adsorvida na superfície das partículas e pesagem adequada. 


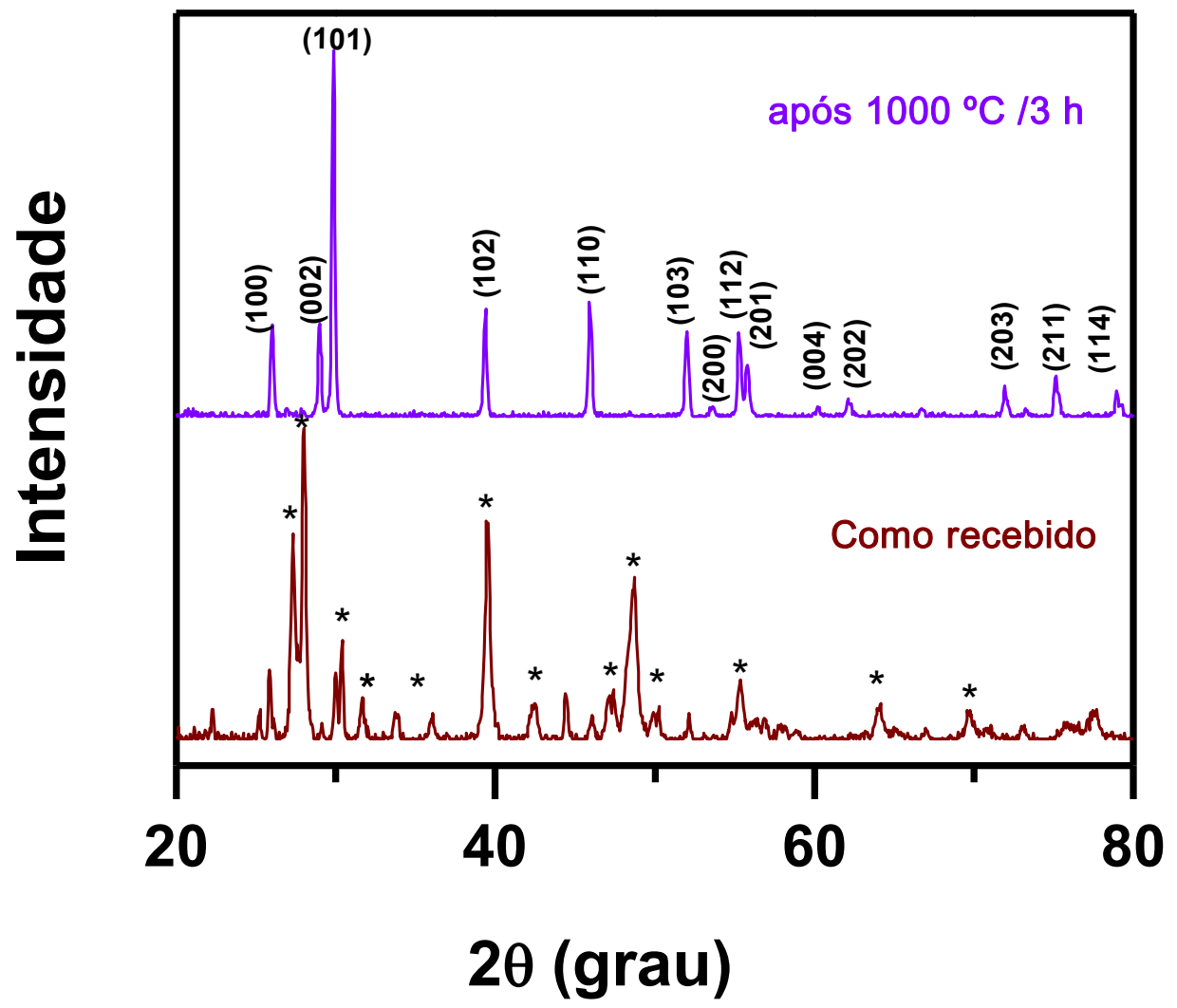

Figura 4: Difratogramas de raios $\mathrm{X}$ do pó de $\mathrm{La}_{2} \mathrm{O}_{3}$ como recebido e após 0 tratamento térmico a $1000 \stackrel{\circ}{\circ} / 3 \mathrm{~h}-\left(^{*}\right) \mathrm{La}(\mathrm{OH})_{3}$.

$\mathrm{O} \mathrm{La}_{2} \mathrm{O}_{3}$ como recebido contém quantidade considerável de $\mathrm{La}(\mathrm{OH})_{3}$ e o tratamento térmico realizado foi suficiente para decompor e obter o $\mathrm{La}_{2} \mathrm{O}_{3}$.

Para obter pós com a menor quantidade possível de fases secundárias, pelo método de mistura de óxidos foram realizadas três etapas de calcinação sucessivas por tempos de $4 \mathrm{~h}$ cada, em temperaturas de $1000\left(\mathrm{C}-1000{ }^{\circ} \mathrm{C}\right)$, $1250\left(\mathrm{C}-1250^{\circ} \mathrm{C}\right)$ e $1350^{\circ} \mathrm{C}\left(\mathrm{C}-1350^{\circ} \mathrm{C}\right)$. Entre cada etapa de calcinação as misturas foram desaglomeradas em almofariz de ágata. Ao final, as misturas foram moídas em moinho tipo atritor em meio alcoólico por $1 \mathrm{~h}$. Outra rota utilizada tem como característica inicial a moagem em moinho tipo atritor seguida de uma $\left(\mathrm{M}-1350^{\circ} \mathrm{C}\right)$ ou duas $\left(\mathrm{M} 2-1350^{\circ} \mathrm{C}\right)$ calcinações a $1350{ }^{\circ} \mathrm{C}$. Ao final, as misturas foram novamente moídas em meio alcoólico por 30 min.

A Figura 5 mostra as etapas realizadas em cada rota de preparação utilizada neste trabalho. 


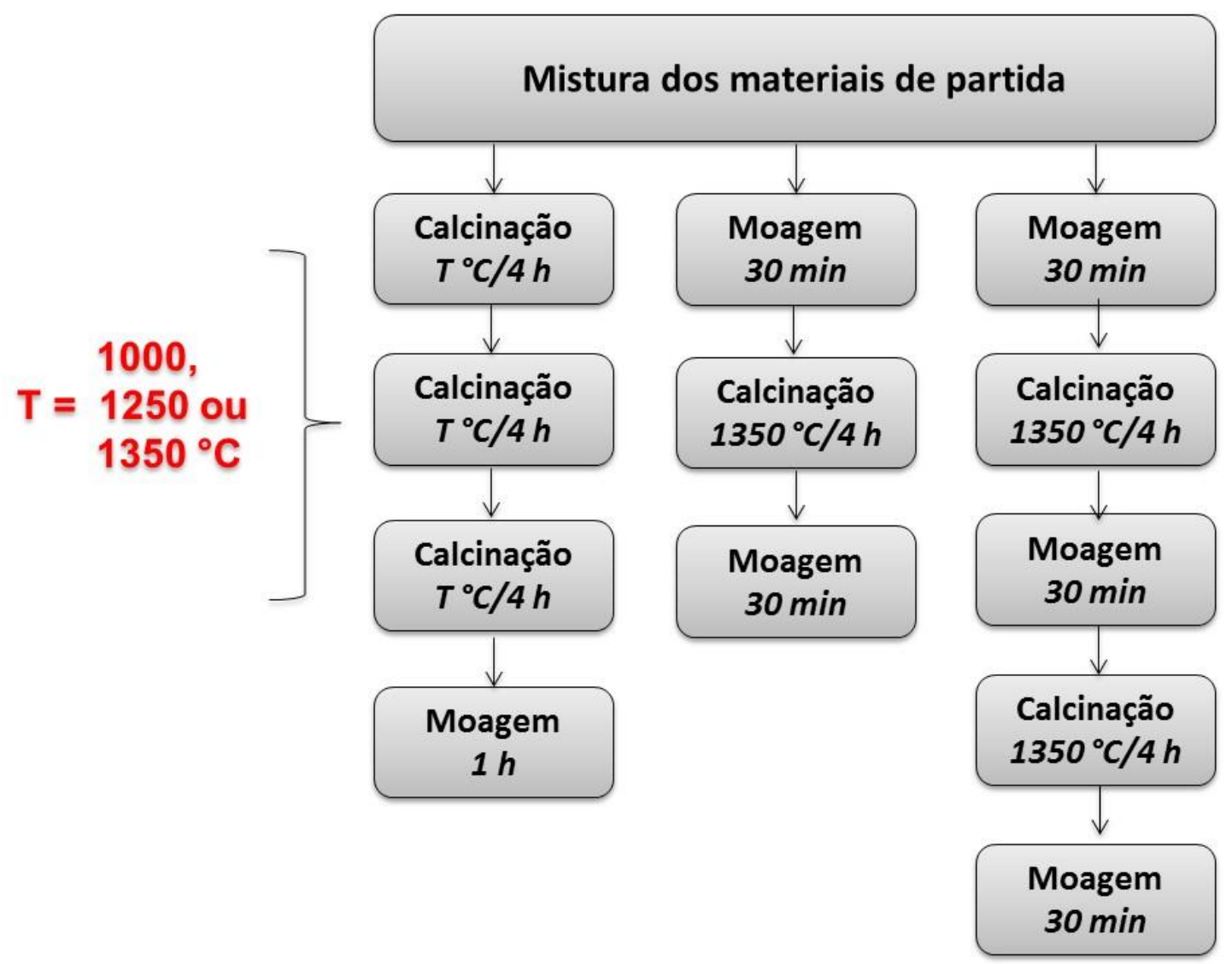

Figura 5: Fluxograma das rotas utilizadas no método de mistura de óxidos.

No fluxograma acima, após cada etapa de processamento, foram feitas medidas de difração de raios $X$ e observação em microscópio eletrônico de varredura. Após o término de cada rota foram realizadas medidas de análise térmica e de dilatometria.

\subsubsection{Complexação de cátions}

O método de complexação de cátions consiste na preparação de compostos químicos constituídos de oxigênio e pelo menos dois outros elementos, e na formação de uma solução estável dos íons constituintes associados a um composto químico preparado pela adição de uma substância orgânica que é fortemente complexante e se decompõe sob a ação do calor [96].

Para obter a composição $\mathrm{La}_{0,9} \mathrm{Sr}_{0,1} \mathrm{Gaa}_{0,8} \mathrm{Mg}_{0,2} \mathrm{O}_{3-\delta}$ pelo método de complexação de cátions com ácido cítrico, inicialmente foram preparadas soluções aquosas de nitratos de lantânio, gálio, magnésio e estrôncio com 
concentração de $1 \mathrm{~mol} / \mathrm{L}$, dissolvendo $\mathrm{La}\left(\mathrm{NO}_{3}\right)_{3} \cdot 6 \mathrm{H}_{2} \mathrm{O}, \mathrm{Ga}\left(\mathrm{NO}_{3}\right)_{3} \cdot \mathrm{xH}_{2} \mathrm{O}$, $\mathrm{Mg}\left(\mathrm{NO}_{3}\right)_{3} .6 \mathrm{H}_{2} \mathrm{O}$ em água destilada. $\mathrm{O} \mathrm{SrCO}_{3}$ foi dissolvido em solução aquosa de ácido nítrico. As concentrações das soluções foram determinadas por gravimetria.

Quantidades estequiométricas das soluções foram mantidas sob aquecimento e agitação em placa aquecedora durante $10 \mathrm{~min}$, para fins de homogeneização. Em seguida, foi adicionado o agente complexante, ácido cítrico anidro, numa relação molar, ácido cítrico: metal igual a 3:1, para evitar a precipitação do estrôncio, mantendo-se a solução sob constante aquecimento $\left(70{ }^{\circ} \mathrm{C}\right)$ e agitação. Após a homogeneização da solução, ocorreu o início da evaporação de água e a saída de vapores de NOx. Posteriormente, com o aumento da viscosidade da solução, houve a formação do gel. Após a eliminação de $\mathrm{NO}_{x}$, foi interrompida a agitação devido ao aumento da viscosidade resultando na formação de uma resina de cor amarela.

As resinas obtidas foram pré-calcinadas a $250^{\circ} \mathrm{C} / 1 \mathrm{~h}$, (forno EDG 1800) com taxa de aquecimento de $2{ }^{\circ} \mathrm{C} / \mathrm{min}$ e resfriamento natural (o forno foi desligado após o término do tratamento isotérmico).

Após o resfriamento o material foi colocado em almofariz de ágata para desaglomeração. Em seguida foi aquecido até $400 \stackrel{\circ}{\circ} \mathrm{com}$ taxa de aquecimento de $2^{\circ} \mathrm{C} / \mathrm{min}$ e em seguida até $800{ }^{\circ} \mathrm{C} / 1 \mathrm{~h}$ com taxa de aquecimento de $1^{\circ} \mathrm{C} / \mathrm{min}$ (forno EDG 1800). Terminado o tempo de patamar, o forno foi resfriado naturalmente.

Medidas de difração de raios $X$ dos pós obtidos pelo método de complexação foram realizadas para identificação das fases cristalinas. Também foram realizadas medidas de dilatometria e análise térmica para estudo do comportamento térmico deste material.

A Figura 6 mostra o fluxograma da sequência experimental utilizada para o método de complexação de cátions. 


\section{SOLUÇÕES DE NITRATO ÁCIDO CÍTRICO}

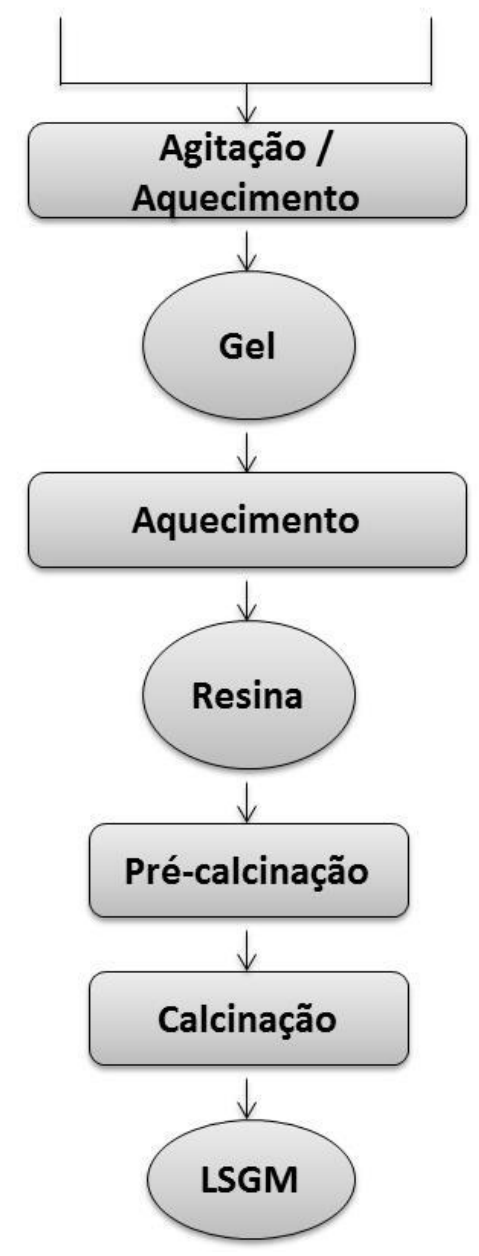

Figura 6: Fluxograma da sequência experimental do método de complexação de cátions.

\subsection{Caracterizações}

Para estudo da formação da fase no LSGM e verificação de fases secundárias nos pós foram realizadas medidas de difração de raios $X$ (BrukerAXS, D8 Advance) no intervalo $20^{\circ} \leq 2 \theta \leq 80^{\circ}$, com passo de $0,05^{\circ}$ e tempo de contagem de $2 \mathrm{~s}$, utilizando radiação $\mathrm{K}_{\alpha}$ do $\mathrm{Cu}(\lambda=1,5405 \AA)$ e filtro de $\mathrm{Ni}$. $\mathrm{A}$ identificação das diversas fases foi feita com o auxílio de fichas ICDD, Tabela III. 
Tabela III - Características das fases cristalinas de interesse.

\begin{tabular}{llll}
\hline Fase & \multicolumn{1}{c}{$\begin{array}{c}\text { Densidade } \\
\left(\mathrm{g} \cdot \mathrm{cm}^{-3}\right)\end{array}$} & $\begin{array}{l}\text { ICDD } \\
\#\end{array}$ & Simetria \\
\hline $\mathrm{La}_{2} \mathrm{O}_{3}$ & 6,573 & $5-602$ & Hexagonal \\
$\mathrm{La}(\mathrm{OH})_{3}$ & $---\mathrm{C}_{3}$ & $36-1481$ & Hexagonal \\
$\mathrm{SrCO}$ & 3,436 & $74-1624$ & Romboédrica \\
$\mathrm{SrO}$ & 5,068 & $75-263$ & Cubica \\
$\mathrm{Ga}_{2} \mathrm{O}_{3}$ & 5,928 & $41-1103$ & Monoclínica \\
$\mathrm{MgO}_{\mathrm{La}\left(\mathrm{GaO}_{3}\right)}^{3,563}$ & 6,986 & $89-7746$ & Cubica \\
$\mathrm{SrLaGa}_{3}$ & 5,240 & $89-8037$ & Romboédrica \\
$\mathrm{La}_{4} \mathrm{Ga}_{2} \mathrm{O}_{9}$ & 5,699 & $45-0637$ & Tetragonal \\
$\mathrm{SrLaGaO}_{4}$ & 6,388 & $53-1108$ & Monoclínica \\
\hline \hline
\end{tabular}

O estudo do comportamento térmico do LSGM foi realizado por análise termogravimétrica (TG) e térmica diferencial (DTA) simultânea (Netzch, STA409E). As medidas foram realizadas a partir da temperatura ambiente até $1400 \stackrel{\circ}{\mathrm{C}} \mathrm{com}$ taxa de aquecimento e resfriamento de $10 \stackrel{\circ}{\circ} \mathrm{C} / \mathrm{min}$ em atmosfera de ar sintético ( $5 \mathrm{~mL} / \mathrm{min})$, utilizando alumina como material de referência.

A verificação composicional dos pós e compactos sinterizados foi realizada utilizando a técnica de fluorescência de raios $X$ (Shimadzu, EDX720).

A análise de retração linear do compacto a verde foi realizada em dilatômetro (Anter, Unitherm 1161), com taxa de aquecimento e resfriamento de $10 \stackrel{\circ}{\circ} / \mathrm{min}$ até $1500{ }^{\circ} \mathrm{C}$, em atmosfera de ar sintético. Neste caso, as amostras de LSGM foram compactadas uniaxialmente em matriz de aço inoxidável de diâmetro igual a $5 \mathrm{~mm}$ com pressão de $50 \mathrm{MPa}$, seguido de compactação isostática a frio a $100 \mathrm{MPa}$.

Amostras cilíndricas foram preparadas por compactação uniaxial em matriz de aço inoxidável de diâmetro igual a $8 \mathrm{~mm}$ e $2 \mathrm{~mm}$ de espessura, com pressão de $18 \mathrm{MPa}$, seguido de compactação isostática a frio a $103 \mathrm{MPa}$.

Os compactos foram sinterizados em diversas temperaturas e tempos de patamar com taxa de aquecimento e resfriamento de $10{ }^{\circ} \mathrm{C} / \mathrm{min}$ pelo método convencional de sinterização. Amostras selecionadas foram consolidados por sinterização rápida na qual a amostra é rapidamente conduzida a temperatura desejada, em 10 min, permanecendo por um tempo específico em seguida é resfriada rapidamente, em $10 \mathrm{~min}$. As condições utilizadas na sinterização 
rápida foram $1450{ }^{\circ} \mathrm{C}$ por 5 ou $10 \mathrm{~min}$ e $1500^{\circ} \mathrm{C} / 5 \mathrm{~min}$. As sinterizações foram realizadas em forno resistivo tipo caixa (Lindberg, 51524, 1700C) e em forno resistivo tubular (Lindberg, Blue M).

Após a sinterização, as amostras foram caracterizadas por meio de medidas de densidade aparente, difração de raios $X$, observação da microestrutura em microscópio eletrônico de varredura e medidas da condutividade elétrica.

Inicialmente foi determinada a densidade aparente das amostras utilizando os métodos geométrico e hidrostático (balança analítica Mettler, $\mathrm{H} 315)$. As dimensões das amostras foram determinadas utilizando um micrômetro da marca Tesa. Foram feitas 10 medidas de diâmetro e 10 de espessura, para obter precisão adequada neste tipo de medida. Para o método hidrostático foram feitas medidas de massa seca, massa úmida e massa imersa, para cada amostra, e 10 medidas em cada caso. Para determinar a densidade relativa utilizou-se a densidade teórica do LSGM como sendo de 6,67 g.cm ${ }^{-3}$ obtida da ficha ICSD \#51-288 [43].

Para o estudo da formação da fase LSGM e verificação de fases secundárias nos compactos foram realizadas medidas de difração de raios $X$, nas mesmas condições de análise descritas anteriormente.

Para o estudo da microestrutura (topografia e composição) as amostras foram observadas utilizando elétrons secundários e retroespalhados, respectivamente, em microscópio eletrônico de varredura (Philips, XL30 e FEI Inspect F50), juntamente com análise por espectrometria de energia dispersiva, EDS, (EDAX, Apollo 10). As amostras foram seccionadas, embutidas, lixadas e polidas com pastas adiamantadas até $1 \mu \mathrm{m}$. Para revelação dos contornos de grãos foi feito ataque térmico em temperatura $100{ }^{\circ} \mathrm{C}$ inferior à da sinterização. O tamanho médio de grãos foi determinado utilizando o método dos interceptos (ou de Mendelson) [112] numa amostragem superior a 500 grãos.

Compactos sinterizados foram caracterizados com relação ao comportamento elétrico por espectroscopia de impedância. As medidas foram realizadas na faixa de frequência de $5 \mathrm{~Hz}$ a $13 \mathrm{MHz}$, no intervalo de temperatura de 280 a $420{ }^{\circ} \mathrm{C}$, com tensão ac aplicada de $100 \mathrm{mV}$ utilizando um analisador de impedância HP 4192A, acoplado a um controlador HP 362. A 
temperatura foi monitorada com termopar tipo K (Cromel-Alumel). Para estas medidas realizou-se a deposição dos eletrodos em faces opostas das amostras com aplicação de pasta de prata (Cerdec), seguida de cura a $400 \stackrel{\circ}{\circ} / 15 \mathrm{~min}$. Os dados de medidas elétricas foram coletados e analisados por meio de programa computacional [113]. 


\section{RESULTADOS E DISCUSSÃO}

Neste capitulo serão apresentados e discutidos os principais resultados obtidos na seguinte sequência: caracterização dos pós (mistura de óxidos e complexação de cátions), caracterização das amostras sinterizadas pelo método convencional de sinterização e por sinterização rápida (caracterização estrutural, densidade, microscopia eletrônica de varredura e espectroscopia de impedância).

\subsection{Caracterização dos pós}

\subsubsection{Mistura de óxidos}

Inicialmente foi realizado um estudo dos pós obtidos pelo método convencional de reação em estado sólido no qual foram empregadas etapas de moagem e calcinação.

A caracterização térmica dos pós precursores foi realizada por análise termogravimétrica e térmica diferencial (DTA) simultânea. A Figura 7 mostra a curva termogravimétrica e térmica diferencial para a mistura obtida com calcinações sucessivas a $1000{ }^{\circ} \mathrm{C}$ após a moagem.

A curva termogravimétrica (TG) mostra três estágios de perda de massa correspondentes a três eventos endotérmicos observados na curva DTA. Esses eventos correspondem à decomposição do $\mathrm{La}(\mathrm{OH})_{3}$ em 400 e $550{ }^{\circ} \mathrm{C}$ e a decomposição do $\mathrm{SrCO}_{3}$ na faixa de $800{ }^{\circ} \mathrm{C}$. Os resultados foram confirmados pelas curvas termogravimétrica e térmica diferencial dos materiais de partida, não mostradas, e revelam a facilidade de absorção de vapor de água da atmosfera ambiente pelo óxido de lantânio dando origem ao hidróxido. Este resultado mostra que a etapa de calcinação deve ser realizada em temperatura superior a $800{ }^{\circ} \mathrm{C}$ para a decomposição térmica total dos materiais de partida. 


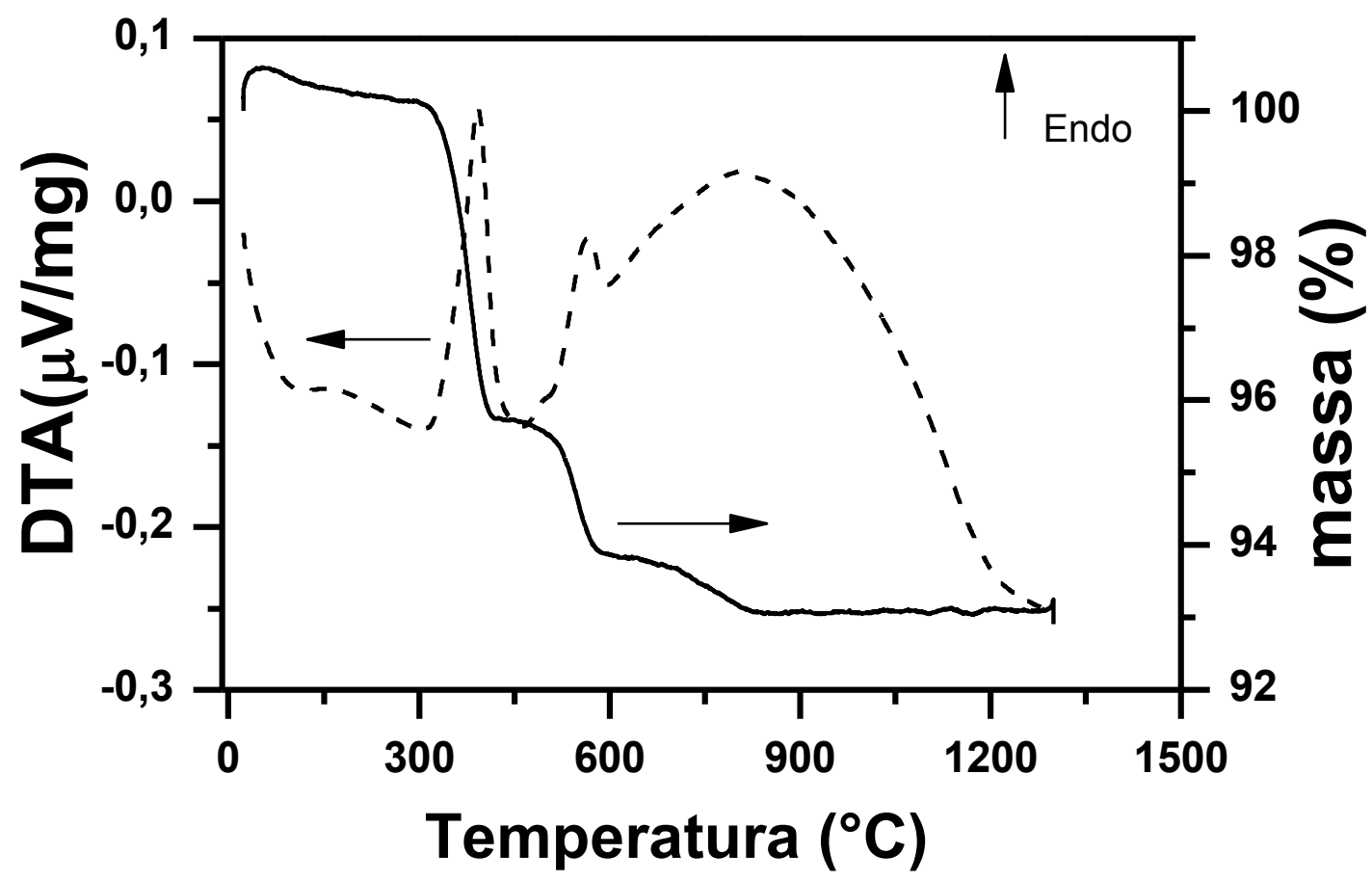

Figura 7: Curvas termogravimétrica (TG) e de análise térmica diferencial (DTA) obtidas para o material preparado com calcinações sucessivas a $1000^{\circ} \mathrm{C}$.

Para os materiais obtidos por calcinações sucessivas a 1250 e $1350{ }^{\circ} \mathrm{C}$ e calcinadas a $1350{ }^{\circ} \mathrm{C}$ com moagens intercaladas não ocorrem perda de massa significativa, ou seja, o aumento na temperatura de calcinação foi suficiente decompor os precursores e promover a formação da solução sólida.

A composição de fases do material foi caracterizada para todas as rotas utilizadas após cada etapa de processamento.

A Figura 8 mostra os difratogramas de raios $X$ dos pós preparados com calcinações sucessivas a $1000{ }^{\circ} \mathrm{C}$ após a mistura, as três calcinações realizadas $\left(1000^{\circ} \mathrm{C} / 12 \mathrm{~h}\right)$ e a moagem $(1 \mathrm{~h})$. 


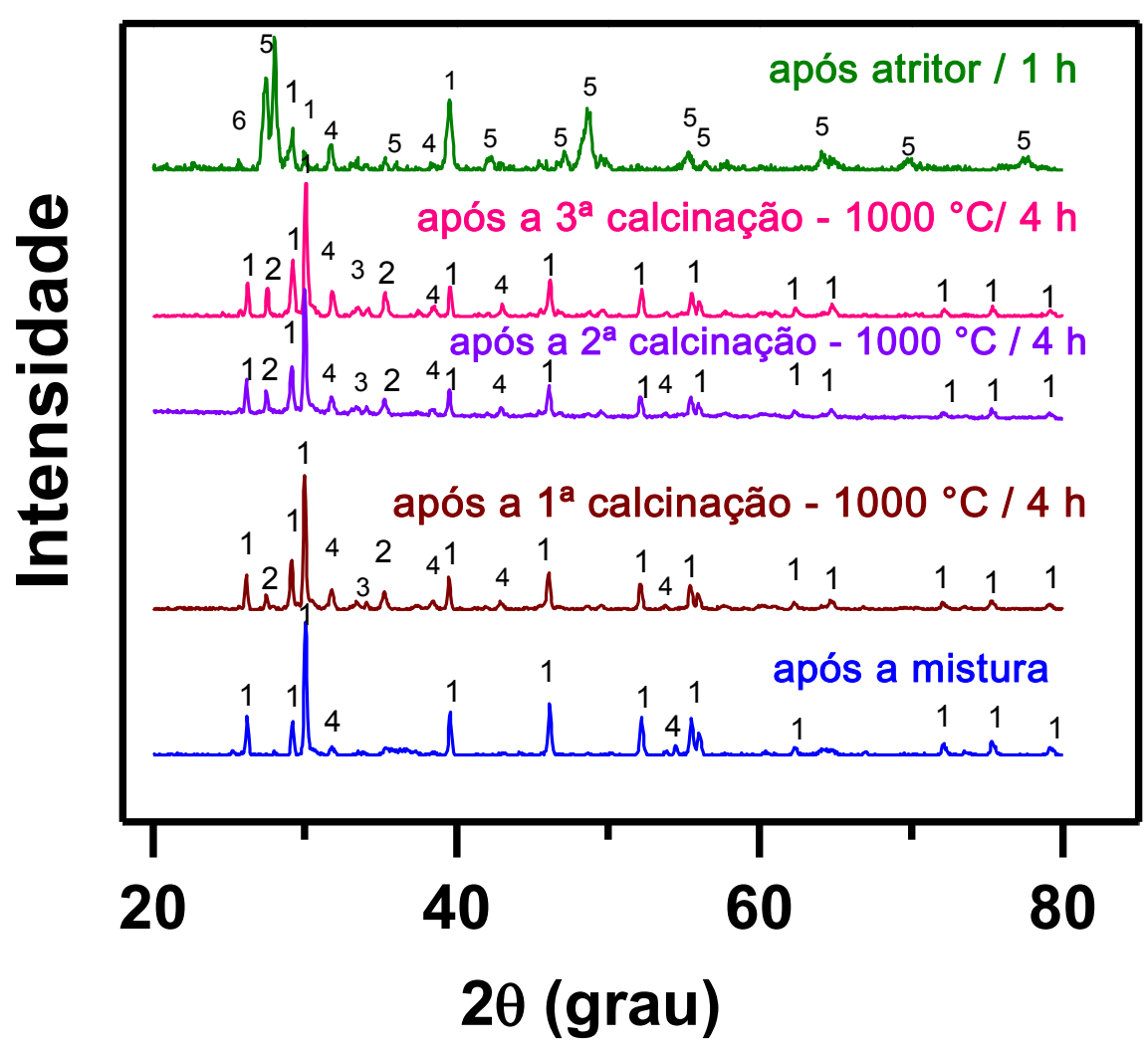

Figura 8: Difratogramas de raios $X$ dos pós com calcinações sucessivas a $1000{ }^{\circ} \mathrm{C}$ após a mistura, calcinações e moagem. 1- $\mathrm{La}_{2} \mathrm{O}_{3}, 2-\mathrm{SrCO}_{3}$, 3-SrLaGaO $4,4-\mathrm{Ga}_{2} \mathrm{O}_{3}, 5-\mathrm{La}(\mathrm{OH})_{3}$ e 6-La4 $\mathrm{Ga}_{2} \mathrm{O}_{9}$.

Após a mistura dos materiais de partida, é possível observar picos referentes à fase hexagonal do $\mathrm{La}_{2} \mathrm{O}_{3}$ e à fase monoclínica do $\mathrm{Ga}_{2} \mathrm{O}_{3}$, sendo que os picos do $\mathrm{La}_{2} \mathrm{O}_{3}$ são mais intensos. Isso ocorre devido ao $\mathrm{La}_{2} \mathrm{O}_{3}$ estar em maior concentração volumétrica que os demais materiais utilizados.

Após a primeira calcinação surgem picos referentes à fase romboédrica do $\mathrm{SrCO}_{3}$, a fase tetragonal do $\mathrm{SrLaGaO}_{4}$. Os picos associados ao $\mathrm{La}_{2} \mathrm{O}_{3} \mathrm{e}$ $\mathrm{Ga}_{2} \mathrm{O}_{3}$ permanecem. Após a segunda e terceira calcinações não são verificadas mudanças significativas nos difratogramas em relação ao material obtido após a primeira calcinação.

Após a moagem, picos associados com a fase hexagonal do $\mathrm{La}(\mathrm{OH})_{3}$ e à fase $\mathrm{La}_{4} \mathrm{Ga}_{2} \mathrm{O}_{9}$ são verificados. Os picos associados com a fase $\mathrm{Ga}_{2} \mathrm{O}_{3}$ e com a fase $\mathrm{La}_{2} \mathrm{O}_{3}$ permanecem, mas em quantidades aparentemente inferiores.

Então, após as três calcinações e a moagem não foi possível obter a fase LSGM, ou seja, temperaturas mais elevadas são necessárias na calcinação para obter a fase ortorrômbica do LSGM. 
A temperatura de calcinação de $1000{ }^{\circ} \mathrm{C}$ é amplamente utilizada para obter o LSGM pelo método de mistura de óxidos [8, 11, 20, 40,56], entretanto, não foi reportada a caracterização das fases dos pós nesta condição. Em geral, as caracterizações são realizadas após as sinterizações, que são feitas em diferentes temperaturas e tempos de patamar.

A Figura 9 mostra micrografias dos pós obtidos por calcinações sucessivas a $1000^{\circ} \mathrm{C}$, sem calcinação, após a $1^{\underline{a}}, 2^{\underline{a}}$ e $3^{\mathrm{a}}$ calcinação e após a moagem, obtidas em microscópio eletrônico de varredura.
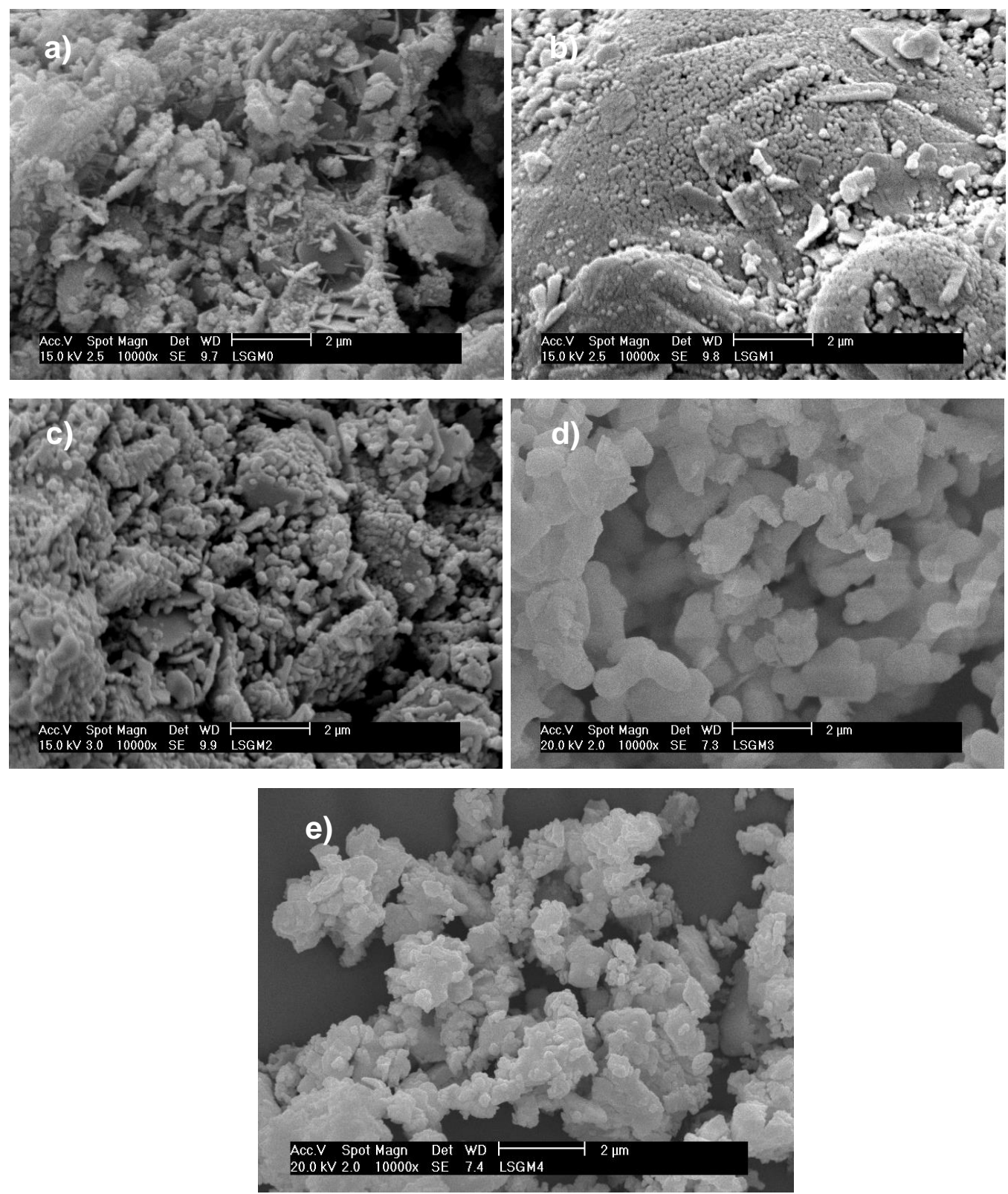

Figura 9: Micrografias dos pós com calcinações sucessivas a $1000^{\circ} \mathrm{C}$, a) sem calcinação, b) após a 1a calcinação, c) após a $2^{\text {a }}$ calcinação, d) após a $3^{\text {a }}$ calcinação e) após moagem. 
As partículas iniciais (Figura 9a) possuem formas (alongadas, achatadas ou irregulares) e tamanhos muito diferentes, dificultando o processo de interação entre as partículas e dificultando a formação da fase (LSGM) durante as etapas de calcinações.

Após as calcinações os materiais particulados são constituídos por aglomerados (Figura 9b-d). Observa-se que somente após a moagem as partículas apresentam características mais uniformes em formato (Figura 9e).

Não foi possível obter a fase ortorrômbica do LSGM para os pós com calcinações sucessivas a $1000{ }^{\circ} \mathrm{C}$, indicando que é necessário aumentar a temperatura de calcinação.

Para obter a fase ortorrômbica do LSGM e minimizar a formação de fases secundárias, aumentou-se a temperatura de calcinação para $1250{ }^{\circ} \mathrm{C}$. Alguns trabalhos reportaram a utilização desta temperatura de calcinação [25, 29, 42, 47, 50]. Entretanto, também não foi reportada a caracterização das fases dos pós nesta condição para a mistura de óxidos.

A Figura 10 mostra os difratogramas de raios $X$ dos pós preparados por calcinações sucessivas a $1250^{\circ} \mathrm{C}$ após mistura, calcinações e moagem.

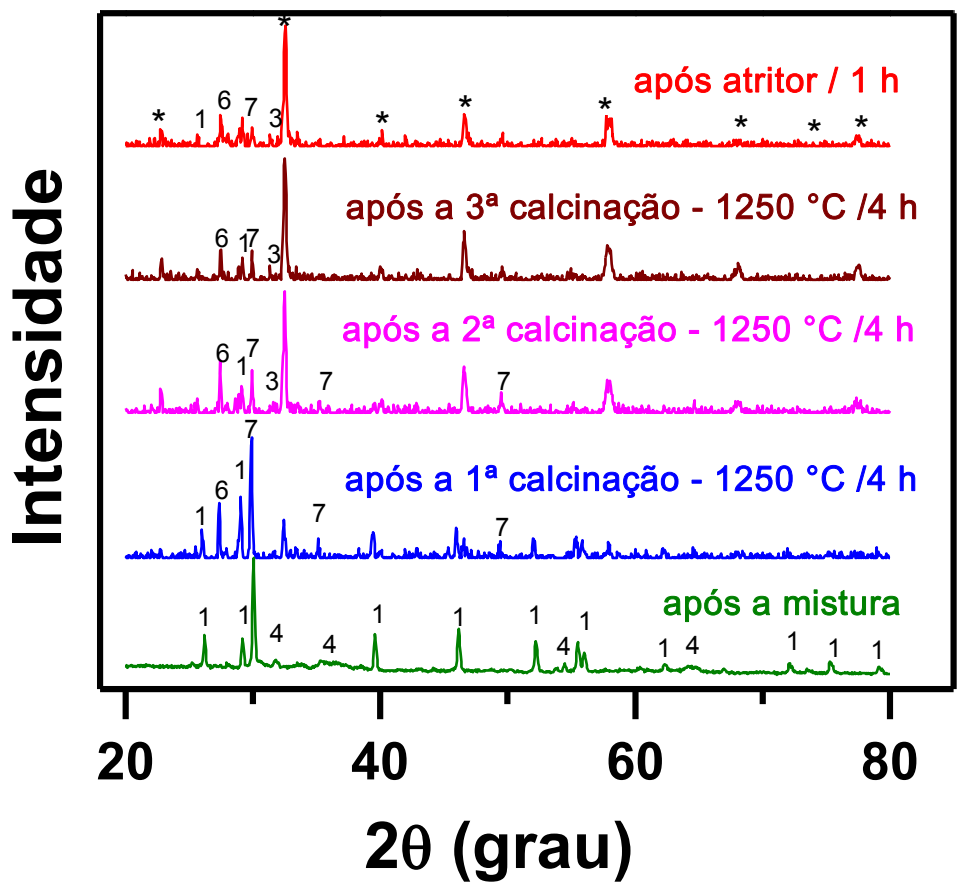

Figura 10: Difratogramas de raios $X$ dos pós com calcinações sucessivas a $1250{ }^{\circ} \mathrm{C}$ após a mistura, calcinações e moagem. 1-La2 $\mathrm{O}_{3}, 3-\mathrm{SrLaGaO}_{4}$, 4- $\mathrm{Ga}_{2} \mathrm{O}_{3}, 6-\mathrm{La}_{4} \mathrm{Ga}_{2} \mathrm{O}_{9}, 7-\mathrm{SrLaGa}_{3} \mathrm{O}_{7}$ e ( $\left.{ }^{*}\right)$ LSGM. 
É possível observar picos de difração referentes à fase ortorrômbica do LSGM [43] logo após a primeira calcinação. Não ocorre variações significativas após a segunda e terceira calcinação. Picos de difração referentes as fases secundárias são detectados mesmo após todas as etapas de processamento.

A Figura 11 mostra micrografias obtidas em microscópio eletrônico de varredura dos pós com calcinações sucessivas a $1250^{\circ} \mathrm{C}$, após a após a $1^{\text {a }}$ (a), $2^{a}$ (b) e $3^{a}$ (c) calcinação e após moagem (d).
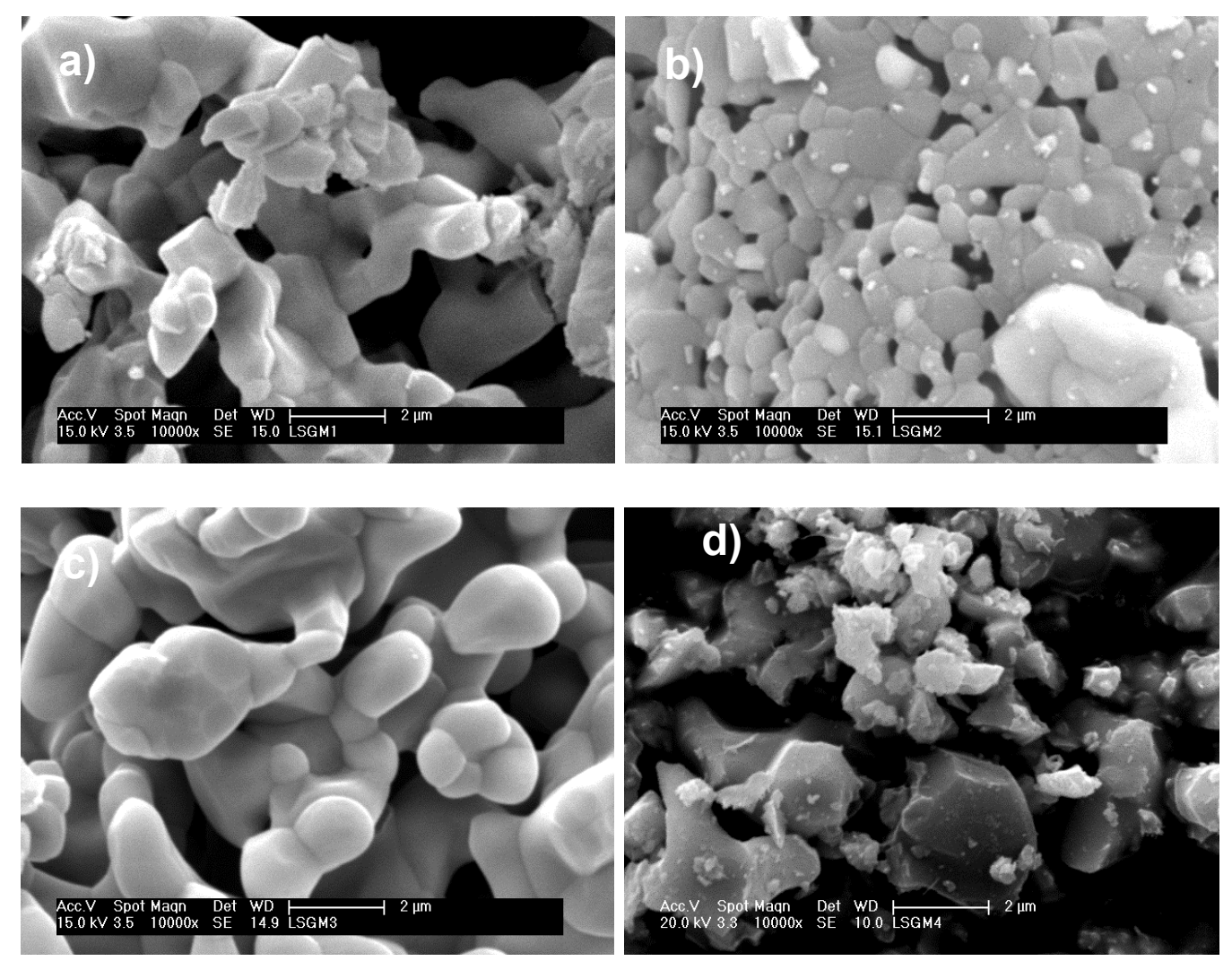

Figura 11: Micrografias dos pós com calcinações sucessivas a $1250{ }^{\circ} \mathrm{C}$, a) após a $1^{\underline{a}}$ calcinação, b) após a $2^{\underline{a}}$ calcinação, c) após a $3^{\underline{a}}$ calcinação e d) após moagem.

Após as calcinações os materiais particulados são constituídos por aglomerados. Além disso, ocorre crescimento no tamanho das partículas e formação de pescoço, (Figura 11c). Após a moagem as partículas apresentam características mais uniformes em formato e tamanho, em relação as partículas iniciais, Figura 9a.

O aumento da temperatura de calcinação promoveu a formação da fase ortorrômbica do LSGM, mas não foi possível eliminar as fases secundárias. 
Então, aumentou-se a temperatura de calcinação neste trabalho para $1350^{\circ} \mathrm{C}$ com o objetivo de obter pós com a fase ortorrômbica do LSGM sem fases secundárias.

A. Moure e colaboradores reportaram que o aumento na temperatura de calcinação elimina a fase $\mathrm{La}_{4} \mathrm{Sr}_{3} \mathrm{O}_{9}$, mas as fases $\mathrm{SrLaGa}_{3} \mathrm{O}_{7}$ e $\mathrm{SrLaGaO}_{4}$ permanecem mesmo após calcinações a $1300 \quad{ }^{\circ} \mathrm{C} / 16 \mathrm{~h}$ para $\mathrm{La}_{0,8} \mathrm{Sr}_{0,2} \mathrm{Ga}_{0,85} \mathrm{Mg}_{0,15} \mathrm{O}_{2,825}$ [13]. Esses resultados estão de acordo com os apresentados anteriormente.

A Figura 12 mostra difratogramas de raios $X$ dos pós com calcinações sucessivas a $1350{ }^{\circ} \mathrm{C}$ após a mistura, as três calcinações $\left(1350^{\circ} \mathrm{C} / 12 \mathrm{~h}\right)$ e a moagem (1 h).

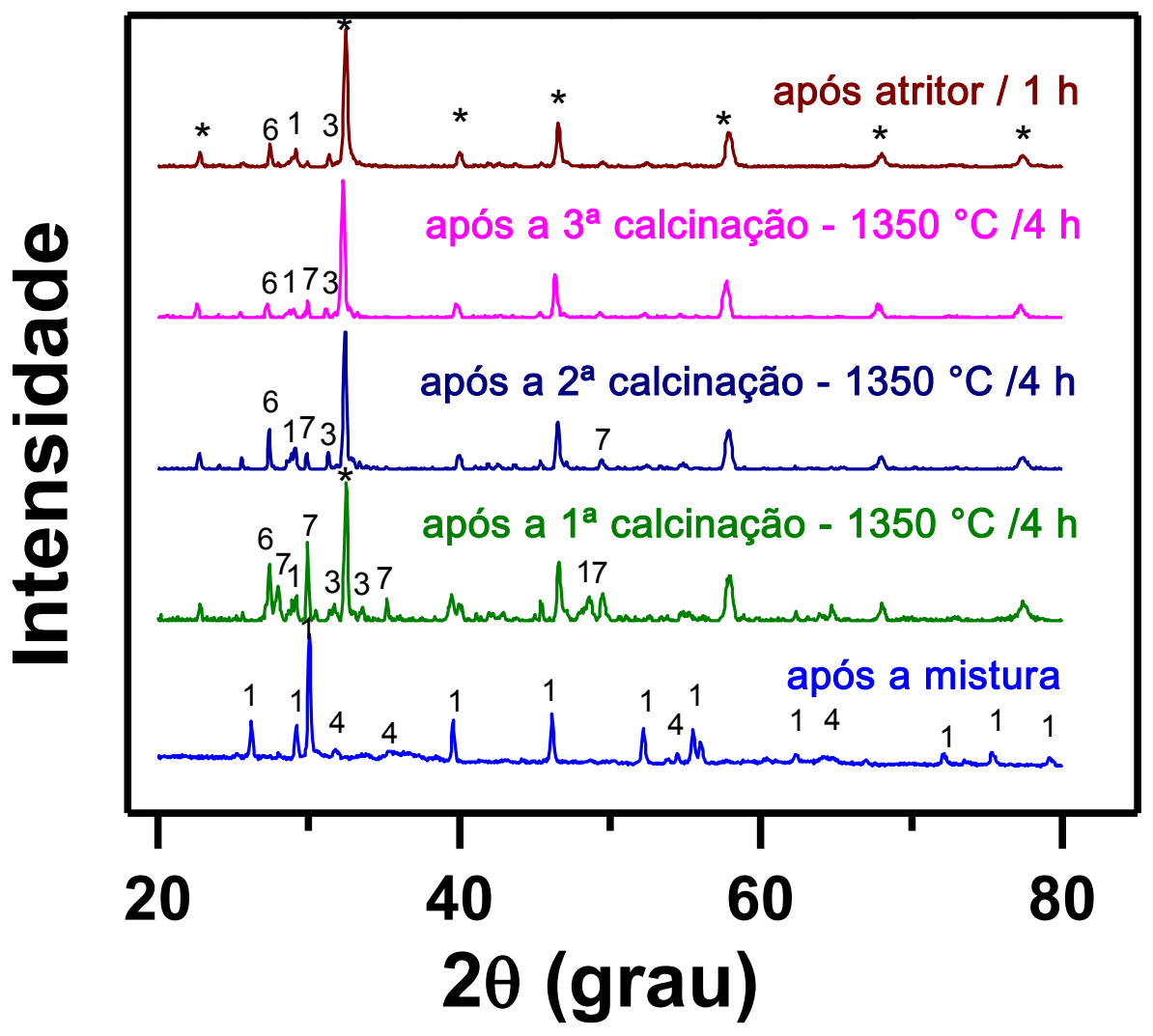

Figura 12: Difratogramas de raios $X$ dos pós com calcinações sucessivas a $1350{ }^{\circ} \mathrm{C}$ após a mistura, calcinações e a moagem. 1- $\mathrm{La}_{2} \mathrm{O}_{3}, 3-\mathrm{SrLaGaO}_{4}$, 4- $\mathrm{Ga}_{2} \mathrm{O}_{3}, 6-\mathrm{La}_{4} \mathrm{Ga}_{2} \mathrm{O}_{9} 7-\mathrm{SrLaGa}_{3} \mathrm{O}_{7}$ e (*) LSGM.

Após a primeira calcinação é possível observar picos referentes à fase ortorrômbica do LSGM [43], e as fases $\mathrm{La}_{4} \mathrm{Ga}_{2} \mathrm{O}_{9}, \mathrm{SrLaGa}_{3} \mathrm{O}_{7}, \mathrm{SrLaGaO}_{4}$ e $\mathrm{La}_{2} \mathrm{O}_{3}$. 
Após a segunda calcinação os picos associados com a fase tetragonal do $\mathrm{SrLaGa}_{3} \mathrm{O}_{7}$ e a fase $\mathrm{La}_{2} \mathrm{O}_{3}$ diminuem e os demais picos permanecem inalterados. Após a terceira calcinação não são verificadas mudanças significativas nos difratogramas em relação ao material obtido após a segunda calcinação. Após a moagem os picos associados com a fase $\mathrm{SrLaGa}_{3} \mathrm{O}_{7}$ desaparecem.

Com o aumento da temperatura de calcinação para $1350^{\circ} \mathrm{C}$ foi possível obter a fase LSGM após a primeira calcinação, porém existem fases secundárias.

Os difratogramas obtidos para os pós com calcinações sucessivas a $1250^{\circ} \mathrm{C}$ e $1350^{\circ} \mathrm{C}$, Figuras 10 e 12 respectivamente, mostram que o aumento da temperatura de calcinação não contribuiu para minimizar a formação das fases secundárias, ou seja, ao final das etapas os pós são semelhantes com relação as fases secundárias.

A Figura 13 mostra micrografias dos pós com calcinações sucessivas a $1350^{\circ} \mathrm{C}$, após as calcinações e moagem.
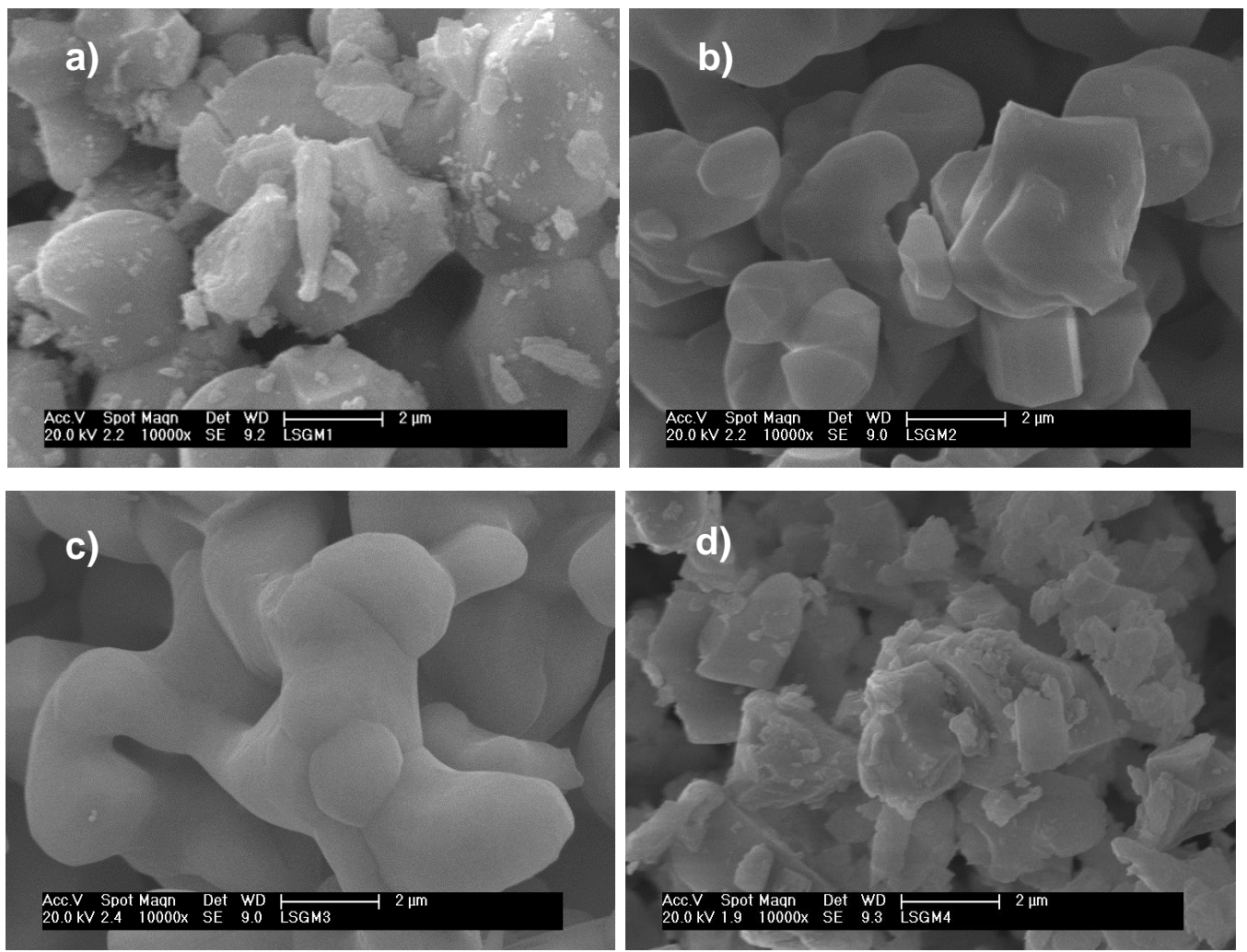

Figura 13: Micrografias obtidas em microscópio eletrônico de varredura dos pós com calcinações sucessivas a $1350^{\circ} \mathrm{C}$ a) após a $1^{\underline{a}}$ calcinação, b) após a $2^{\underline{a}}$ calcinação, c) após a $3^{\mathrm{a}}$ calcinação e d) após a moagem. 
Após as calcinações os materiais particulados são constituídos por aglomerados. Além disso, ocorre crescimento no tamanho das partículas e formação de pescoço (Figura 13c). O aumento da temperatura de calcinação promoveu um aumento no tamanho médio das partículas, quando comparado com os pós preparados por calcinações sucessivas a $1250{ }^{\circ} \mathrm{C}$, Figura 11. Após a moagem as partículas apresentam características mais uniformes em formato e tamanho, em relação as partículas iniciais, Figura 9a.

As partículas iniciais são diferentes, em forma e tamanho dificultando a formação da fase LSGM e favorecendo a formação de fases secundárias, como evidenciado na Figura 9. Além disso, utilizando etapas sucessivas de calcinação a $1250^{\circ} \mathrm{C}$ e $1350^{\circ} \mathrm{C}$ não foi possível obter a fase ortorrômbica do LSGM sem fases secundárias nos pós. Então, no intuito de minimizar a formação dessas fases secundárias foi utilizada outra rota, intercalando a moagem com a calcinação na temperatura de $1350^{\circ} \mathrm{C}$.

Os pós preparados com calcinações a $1350{ }^{\circ} \mathrm{C}$ com moagens intercaladas também foram caracterizados para o estudo da formação da fase LSGM.

A Figura 14 mostra difratogramas de raios $X$ dos pós com duas calcinações a $1350{ }^{\circ} \mathrm{C}$ com moagens intercaladas, após a mistura, a moagem (30 min), calcinação (1350 으 $/ 4 \mathrm{~h}$ ), moagem (30 min), calcinação (1350 ํㅡㄴ $\mathrm{h}$ ) e moagem (30 min).

Após a primeira moagem surgem picos referentes à fase $\mathrm{La}(\mathrm{OH})_{3}$. Os picos referentes aos $\mathrm{La}_{2} \mathrm{O}_{3}$ e $\mathrm{Ga}_{2} \mathrm{O}_{3}$ não são detectados.

Após a primeira calcinação é possível observar picos referentes à fase ortorrômbica do LSGM e ao SrLaGaO 4 . Os picos referentes ao $\mathrm{La}(\mathrm{OH})_{3}$ desaparecem. Nas etapas seguintes, não são verificadas mudanças significativas nos difratogramas. 


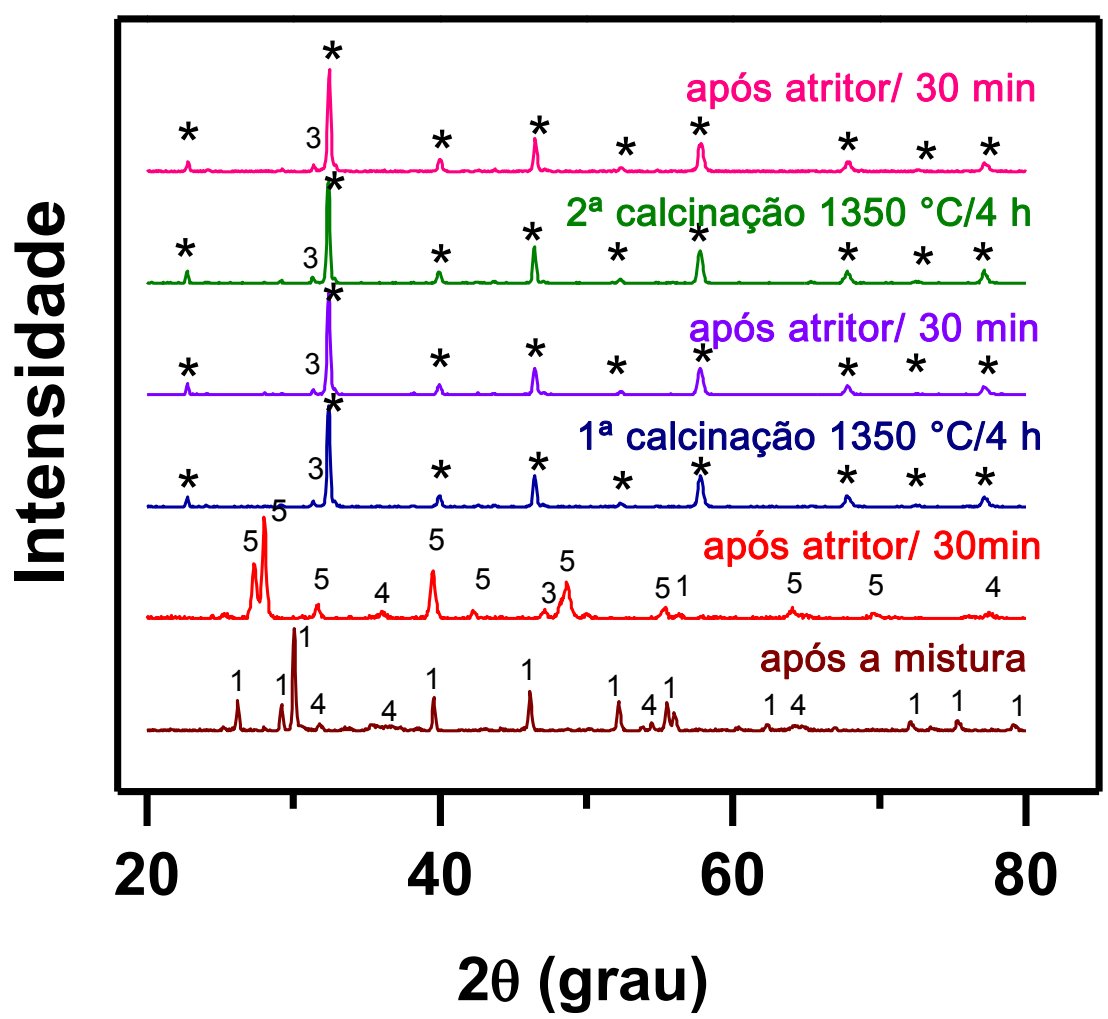

Figura 14: Difratogramas de raios $X$ dos pós com duas calcinações a $1350{ }^{\circ} \mathrm{C}$ com moagens intercaladas após a mistura, moagens e calcinações. 1- $\mathrm{La}_{2} \mathrm{O}_{3}$, 3-SrLaGaO $4,4-\mathrm{Ga}_{2} \mathrm{O}_{3} 5-\mathrm{La}(\mathrm{OH})_{3}$ e (*) LSGM.

Nos pós calcinados a $1350{ }^{\circ} \mathrm{C}$ com moagens intercaladas, foi possível obter a fase ortorrômbica do LSGM a partir da primeira calcinação (Figura 14), semelhante aos pós preparados com calcinações sucessivas a 1250 e 1350 ${ }^{\circ} \mathrm{C}$, (Figuras 10,12). O aumento da temperatura de calcinação e a realização de moagem logo após a mistura facilitou a formação da fase desejada. Entretanto, após a $2^{\mathrm{a}}$ calcinação não foi possível eliminar a fase $\mathrm{SrLaGaO}_{4}$.

Ao final das etapas de processamento, os pós preparados com duas calcinações a $1350{ }^{\circ} \mathrm{C}$ com moagens intercaladas, Figura 14 , aparentemente possui menor teor de fases secundárias quando comparado aos pós obtidos com calcinações sucessivas a 1250 e $1350^{\circ} \mathrm{C}$, Figuras 10, 12.

Observações no microscópio eletrônico de varredura também foram realizadas para os pós calcinados a $1350^{\circ} \mathrm{C}$ com moagens intercaladas, Figura 15. 

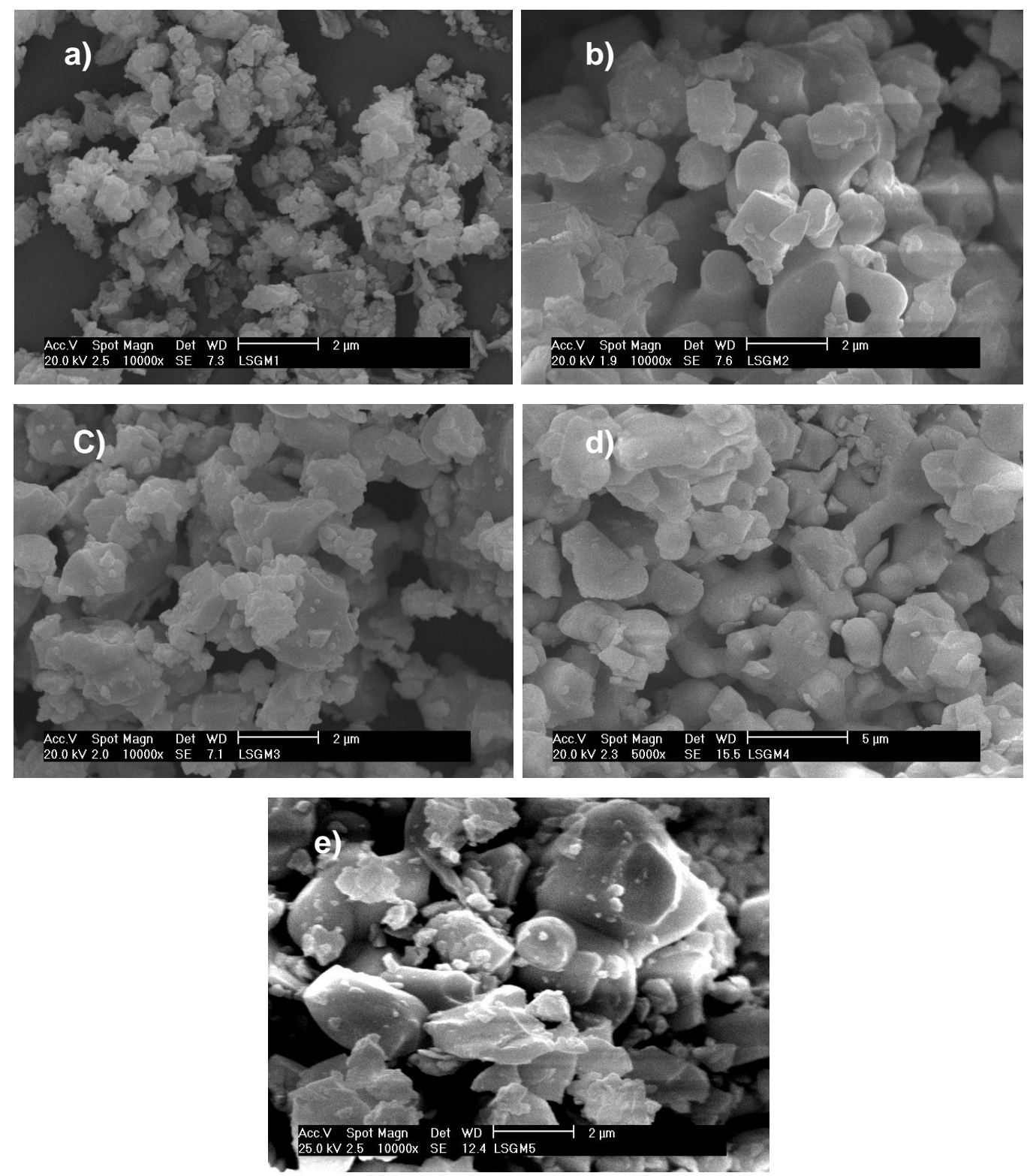

Figura 15: Micrografias obtidas em microscópio eletrônico de varredura dos pós calcinados a $1350{ }^{\circ} \mathrm{C}$ com moagens intercaladas a) após $1^{\text {a }}$ moagem, b) após $1^{\underline{a}}$ calcinação, c) após $2^{\underline{a}}$ moagem, d) 2 $2^{\underline{a}}$ calcinação, e e) após $3^{\underline{a}}$ moagem.

Após a primeira etapa de moagem as partículas apresentam mais uniformidade em formato e tamanho, quando comparadas com as partículas iniciais.

Após a primeira calcinação é possível observar o início da sinterização com a formação de pescoço, Figura 15b. Os materiais particulados são constituídos por aglomerados e ocorre crescimento das partículas.

Após a segunda moagem os aglomerados são parcialmente desintegrados. Após a segunda calcinação (Figura 15d) ocorre um crescimento 
adicional no tamanho das partículas. Após a terceira etapa de moagem os aglomerados são novamente desintegrados.

A segunda calcinação a $1350{ }^{\circ} \mathrm{C}$ foi realizada para tentar eliminar a fase secundária detectada no difratograma de raios X, Figura 14. Entretanto mesmo após o tratamento térmico não foi possível eliminar essa fase. Então, utilizou-se também os pós consistindo apenas de moagem (30 min), calcinação (1350 ํ/4 h) e moagem (30 min), no estudo das amostras de LSGM.

Não foi possível obter pelo método de mistura de óxidos de LSGM sem fases secundárias, entretanto, os pós com duas calcinações a $1350{ }^{\circ} \mathrm{C}$ com moagens intercaladas aparentemente apresentaram menor teor de fases secundárias do que aqueles preparados com calcinações sucessivas a 1000, 1250 e $1350{ }^{\circ} \mathrm{C}$.

\subsubsection{Complexação de cátions}

A seguir serão apresentadas as caracterizações realizadas para os pós preparados pelo método de complexação de cátions.

A Figura 16 mostra as curvas de análise termogravimétrica e análise térmica diferencial da resina preparada pelo método de complexação de cátions.

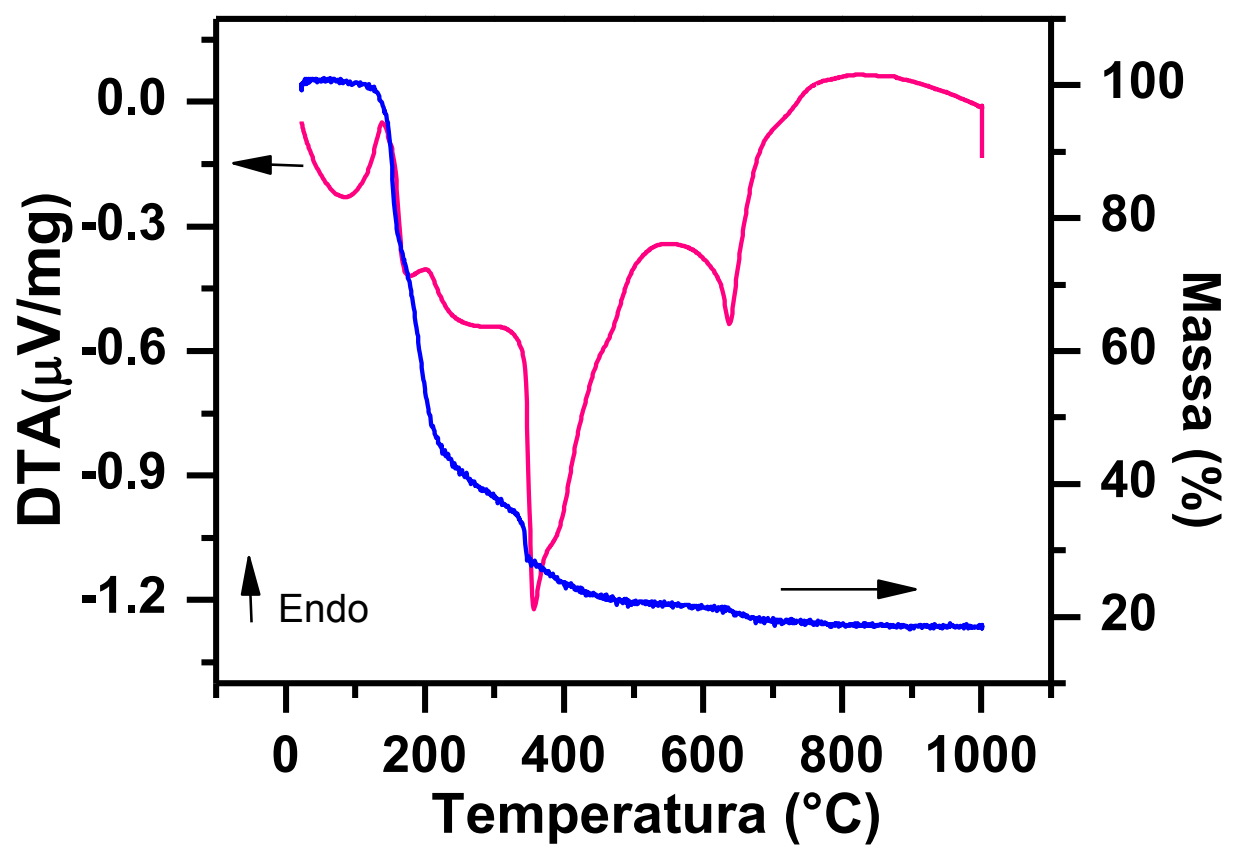

Figura 16: Curvas termogravimétrica (TG) e térmica diferencial (DTA) obtidas da resina preparada pela técnica de complexação de cátions. 
A perda de massa neste caso foi de $21 \%$, Figura 16, e está de acordo com a perda de massa teórica que é de $18 \%$.

São observados três estágios de perda de massa, que estão associados com eventos térmicos. Dentre os diversos eventos térmicos os mais importantes são: um pico endotérmico na temperatura próxima de $140{ }^{\circ} \mathrm{C}$ correspondente à desidratação, outro pico endotérmico em aproximadamente $200{ }^{\circ} \mathrm{C}$ e um pico exotérmico na temperatura de $355^{\circ} \mathrm{C}$ correspondentes à decomposição do ácido cítrico livre e ao início da decomposição de orgânicos, respectivamente. Por fim, o pico exotérmico em aproximadamente $635{ }^{\circ} \mathrm{C}$ corresponde à combustão dos produtos de decomposição.

A Figura 17 mostra os difratogramas obtidos a partir da resina formada, do material pré-calcinado e calcinado para o material preparado pelo método de complexação de cátions.

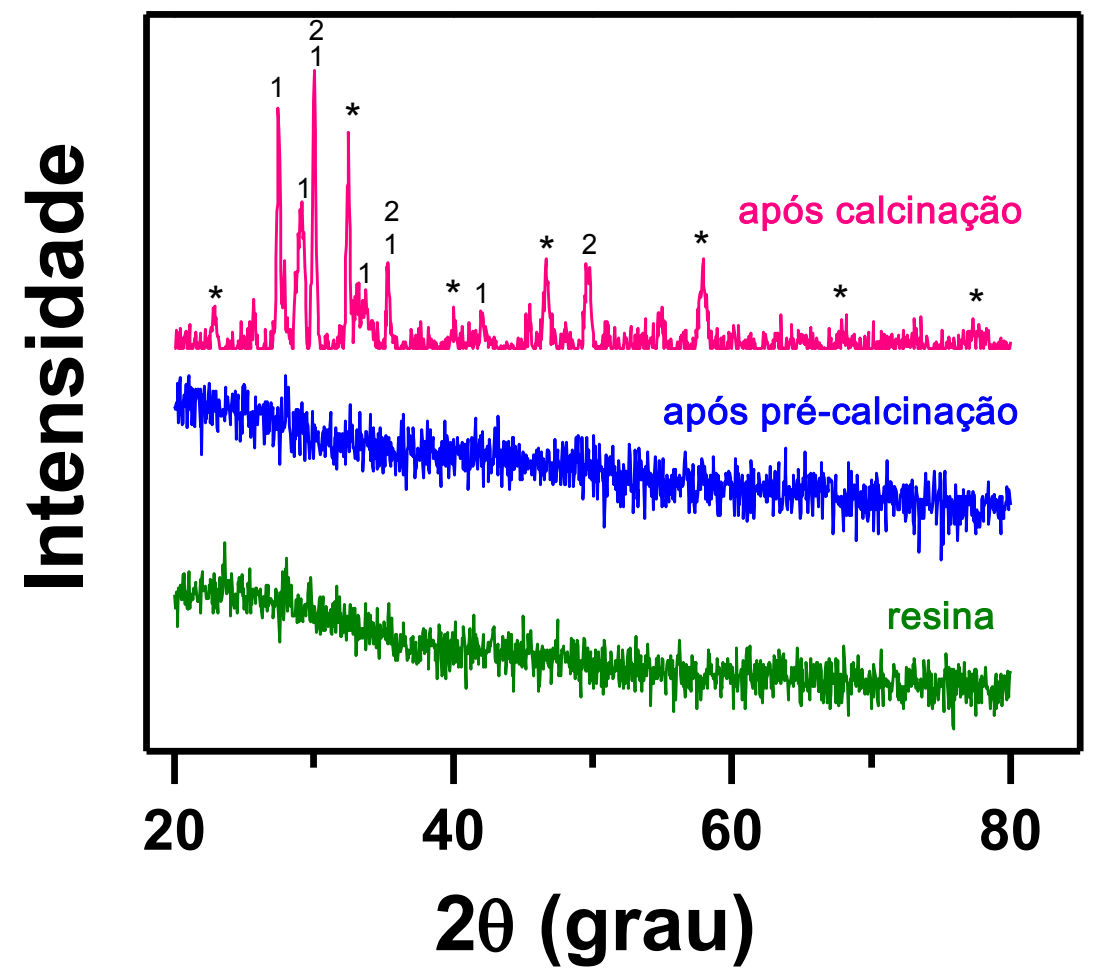

Figura 17: Difratogramas de raios $X$ do material obtido pelo método de complexação de cátions, após a obtenção resina, pré-calcinação e calcinação. 1- $\mathrm{Sr}_{3} \mathrm{La}_{4} \mathrm{O}_{9}, 2-\mathrm{SrO}$ e $\left(^{*}\right)$ LSGM. 
Observa-se que a resina e o material pré-calcinado $\left(250^{\circ} \mathrm{C} / 1 \mathrm{~h}\right)$ são amorfos e que após calcinação $\left(800^{\circ} \mathrm{C} / 1 \mathrm{~h}\right)$ verifica-se o surgimento dos picos da fase LSGM, e de picos de fases secundárias: $\mathrm{Sr}_{3} \mathrm{La}_{4} \mathrm{O}_{9}$ e SrO. Para os pós preparados pelo método de complexação de cátions calcinados a $800{ }^{\circ} \mathrm{C}$ foi possível obter a fase ortorrômbica do LSGM diferente do que ocorreu para os pós preparados pelo método de mistura de óxidos, em que temperaturas superiores a $1000{ }^{\circ} \mathrm{C}$ são necessárias para obter a fase do LSGM.

Quando preparados pelo método de complexação de cátions, os pós pré-calcinados são amorfos, resultado similar ao reportado por A. C. Tas, [78] utilizando o método Pechini e M. Shi e colaboradores utilizando o método solgel [77]. No entanto, M. Shi e colaboradores [77] reportaram que utilizando o método Pechini foi possível obter a fase do LSGM em pós não calcinados.

A temperatura de calcinação, $800{ }^{\circ} \mathrm{C}$, para obter picos de difração da fase LSGM pelo método de complexação de cátions foi inferior a dos pós preparados pelo método de mistura de óxidos, superior a $1000^{\circ} \mathrm{C}$.

Observações no microscópio eletrônico de varredura também foram realizadas para os materiais preparados pelo método de complexação de cátions após pré-calcinação e calcinação, como mostrado na Figura 18.

As micrografias evidenciam que os pós são constituídos por aglomerados e apresentam morfologia e porosidade semelhantes com tamanho médio de aproximadamente $60 \mu \mathrm{m}$.

Os pós obtidos pelo método de complexação de cátions possuem morfologia e porosidade diferentes dos pós obtidos pelo método de mistura de óxidos.

Temperaturas superiores a $1000^{\circ} \mathrm{C}$ são necessárias para obter a fase do LSGM pelo método de mistura de óxidos, porém com teores de fases secundárias que podem ser minimizadas quando é intercalado moagens e calcinações. A temperatura de $800{ }^{\circ} \mathrm{C}$ é suficiente para obter a fase do LSGM utilizando o método de complexação de cátions, também com fases secundárias. 

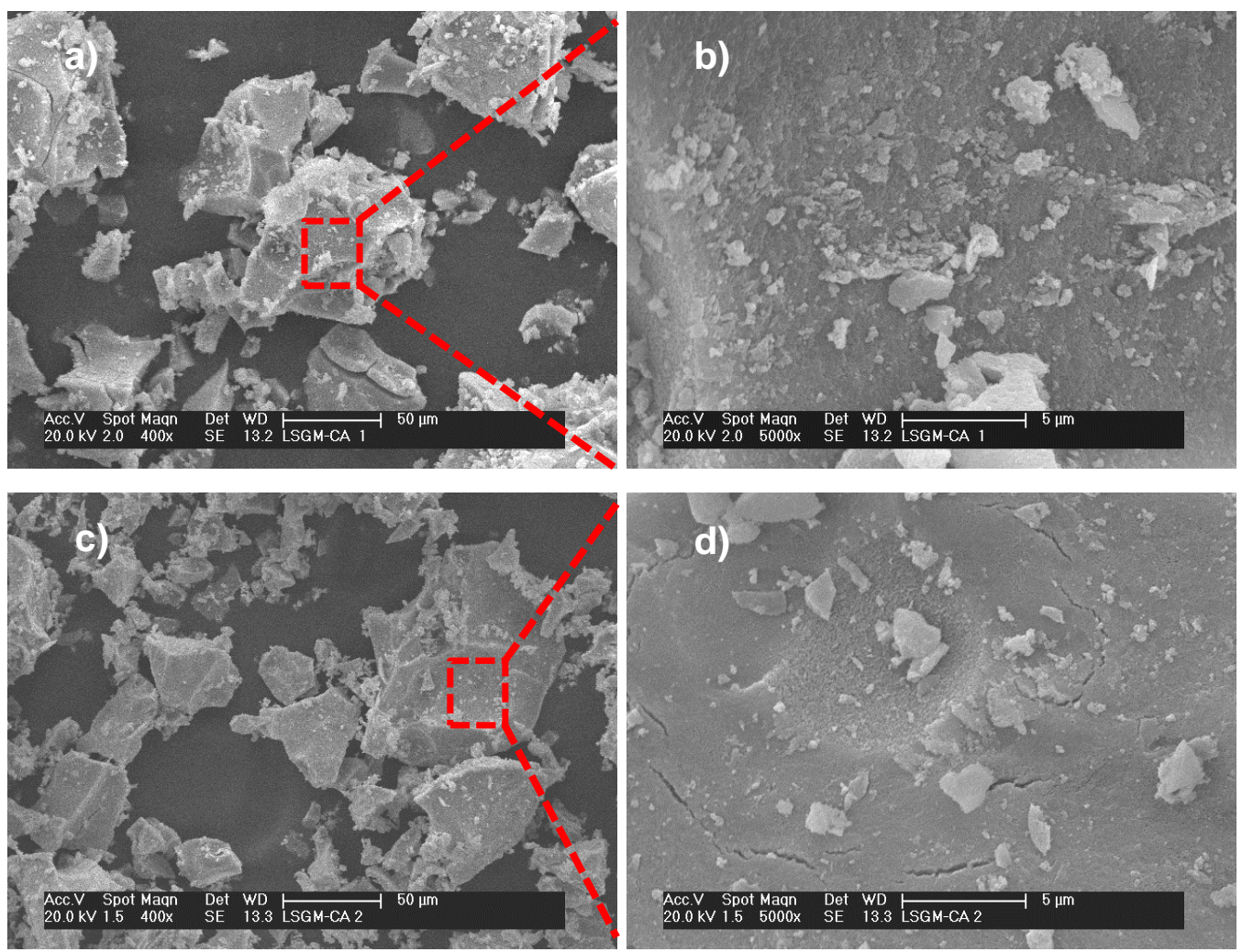

Figura 18: Micrografias obtidas em microscópio eletrônico de varredura dos pós preparados pela técnica de complexação de cátions com diferentes aumentos: (a, b) após pré-calcinação, (c, d) após calcinação.

A Figura 19 mostra as curvas de retração linear de compactos a verde do LSGM nas diferentes rotas estudadas obtida por meio de dilatometria.

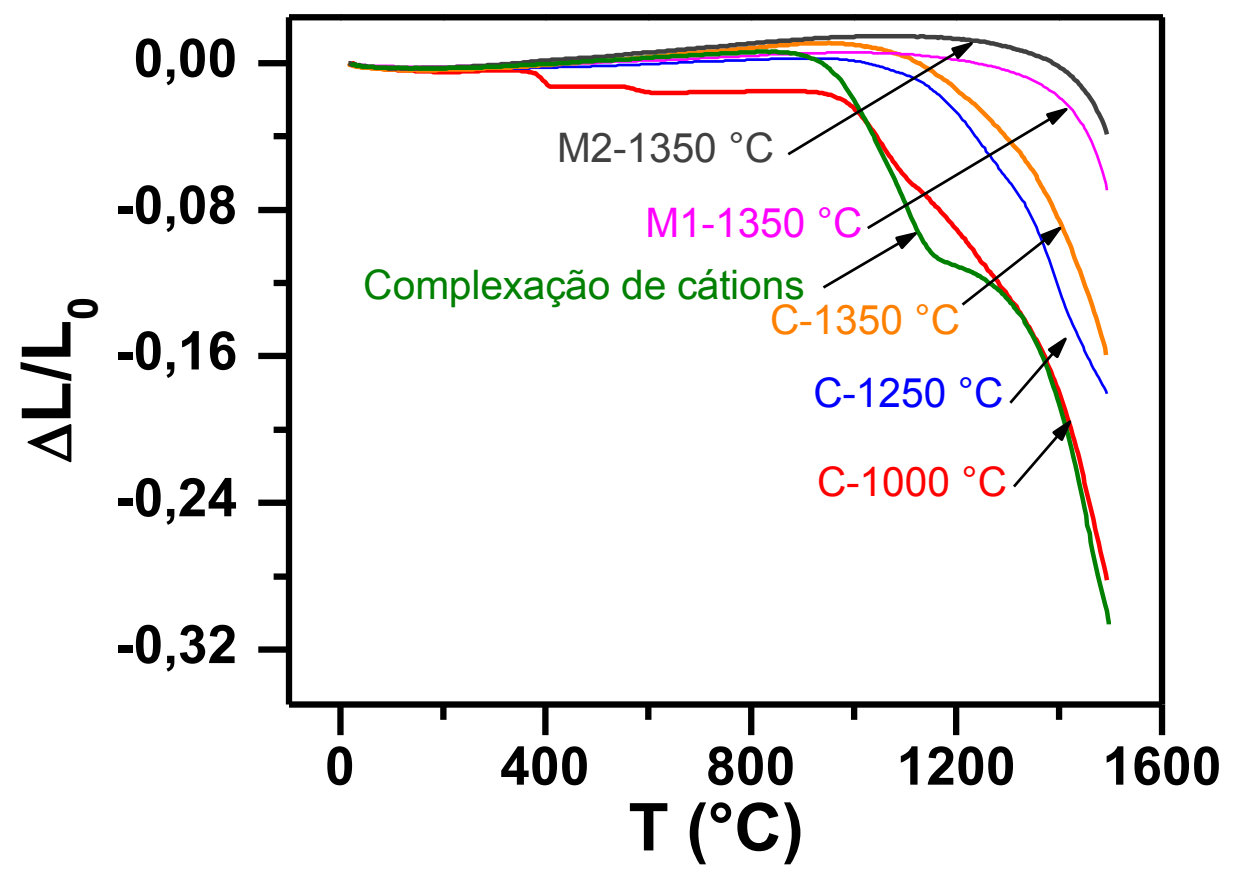

Figura 19: Curvas de retração linear dos compactos preparados com as misturas obtidas pelo método de complexação de cátions e mistura de óxidos. 
O compacto preparado com a mistura obtida por calcinações sucessivas a $1000^{\circ} \mathrm{C}$ exibe uma retração inicial entre $400^{\circ} \mathrm{C}$ que se estende até $800^{\circ} \mathrm{C}$, devida à perda de massa que ocorre nessa rota de preparação, Figura 7. De forma geral, os compactos preparados de acordo com a sequência de três calcinações seguida de moagem apresentam maior retração linear que aqueles nos quais estas etapas foram alternadas, Tabela IV, [114].

A retração total obtida para o compacto preparado pela técnica de complexação de cátions até $1500{ }^{\circ} \mathrm{C}$ foi de $31 \%$, que é superior àquela obtida para os materiais preparados por misturas de óxidos, Tabela IV. A retração ocorre em duas etapas com temperatura inicial de retração de aproximadamente $950{ }^{\circ} \mathrm{C}$. Na temperatura de aproximadamente $1155{ }^{\circ} \mathrm{C}$ ocorre uma mudança na inclinação da curva, este fenômeno provavelmente está associado com a formação de aglomerados sólidos (ou densos), sugeridos por microscopia eletrônica de varredura, Figuras 18b e 18d.

A Tabela IV mostra os valores obtidos pelas medidas de retração linear para a retração total e temperatura inicial de retração dos pós preparados pelo método de mistura de óxidos e pelo método de complexação de cátions.

Tabela IV - Retração total até $1500{ }^{\circ} \mathrm{C}$ e temperatura inicial dos compactos preparados pelas diferentes rotas.

\begin{tabular}{ccc}
\hline \hline Rota & Retração total & Temperatura Inicial (․) \\
\hline C-1000 & $28 \%$ & $\sim 982$ \\
C-1250 & $18 \%$ & $\sim 1091$ \\
C-1350 & $17 \%$ & $\sim 1072$ \\
M-1350 & $8 \%$ & $\sim 1209$ \\
M2-1350 & $3 \%$ & $\sim 1226$ \\
$\begin{array}{c}\text { Complexação } \\
\text { de cátions }\end{array}$ & $31 \%$ & $\sim 950$ \\
\hline \hline
\end{tabular}

A verificação estequiométrica dos pós preparados pelo método de mistura de óxidos e por complexação de cátions foi realizada por fluorescência de raios $\mathrm{X}$, Tabelas $\mathrm{V}$ e $\mathrm{VI}$. 
Tabela V - Fração molar dos elementos dos pós de LSGM determinados por fluorescência de raios $X$.

\begin{tabular}{ccccccc}
\hline \hline & $\begin{array}{c}\text { Composição } \\
\text { Nominal }\end{array}$ & $\begin{array}{c}\text { Complexação } \\
\text { de cátions }\end{array}$ & C-1000 & C-1250 & M-1350 & $\begin{array}{c}\text { M2- } \\
\mathbf{1 3 5 0}\end{array}$ \\
\hline $\mathrm{La}$ & 0,9 & 0,80 & 0,82 & 0,76 & 0,85 & 0,79 \\
$\mathrm{Sr}$ & 0,1 & 0,17 & 0,14 & 0,16 & 0,14 & 0,15 \\
$\mathrm{Ga}$ & 0,8 & 0,93 & 0,91 & 0,97 & 0,89 & 0,96 \\
$\mathrm{Mg}$ & 0,2 & 0,12 & 0,13 & 0,21 & 0,11 & 0,12 \\
\hline \hline
\end{tabular}

Os resultados estão aproximadamente de acordo com a composição nominal. Os desvios estequiométricos observados podem ser associados às incertezas da técnica utilizada. O valor encontrado para $\mathrm{Mg}$ é menor do que o esperado, pois este está no limite de detecção da técnica.

Para avaliar a estequiometria dos compactos após a sinterização, foram realizadas medidas de fluorescência de raios X, Tabela VI.

Tabela VI - Fração molar dos elementos das amostras de LSGM sinterizadas em diversas condições determinados por fluorescência de raios $X$.

\begin{tabular}{|c|c|c|c|c|c|c|}
\hline & $\begin{array}{l}\text { Complexação } \\
\text { de cátions } \\
1450^{\circ} \mathrm{C} / 4 \mathrm{~h}\end{array}$ & $\begin{array}{c}\mathrm{C}-1250 \\
1450^{\circ} \mathrm{C} / 1 \mathrm{~h}\end{array}$ & $\begin{array}{c}\mathrm{C}-1250 \\
1450^{\circ} \mathrm{C} / 2 \mathrm{~h}\end{array}$ & $\begin{array}{c}\mathrm{C}-1250 \\
1450^{\circ} \mathrm{C} / 4 \mathrm{~h}\end{array}$ & $\begin{array}{c}\mathrm{C}-1250 \\
1500^{\circ} \mathrm{C} / 6 \mathrm{~h}\end{array}$ & $\begin{array}{c}\mathrm{M} 2-1350 \\
1450^{\circ} \mathrm{C} / 4 \mathrm{~h}\end{array}$ \\
\hline $\mathrm{La}$ & 0,84 & 0,81 & 0,79 & 0,78 & 0,81 & 0,86 \\
\hline $\mathrm{Sr}$ & 0,15 & 0,14 & 0,14 & 0,14 & 0,14 & 0,13 \\
\hline $\mathrm{Ga}$ & 0,85 & 0,93 & 0,93 & 0,93 & 0,94 & 0,88 \\
\hline $\mathrm{Mg}$ & 0,20 & 0,15 & 0,23 & 0,29 & 0,15 & 0,09 \\
\hline
\end{tabular}

Os resultados obtidos para os compactos estão de acordo com os resultados obtidos para a fluorescência de raios $X$ dos pós. Não ocorreu mudança na estequiometria das amostras independentemente do método de síntese empregado ou condições de sinterização utilizadas.

\subsection{Caracterizações das amostras sinterizadas}

\subsubsection{Sinterização Convencional}

\section{Caracterização estrutural}

Inicialmente as amostras preparadas por misturas de óxidos foram sinterizadas a $1450{ }^{\circ} \mathrm{C}$ por $4 \mathrm{~h}$ ao ar. A Figura 20 mostra os difratogramas de 
raios $\mathrm{X}$ para todas as rotas utilizadas obtidas por mistura de óxidos. A figura à direita corresponde a uma ampliação da faixa angular onde as fases secundárias são detectadas.

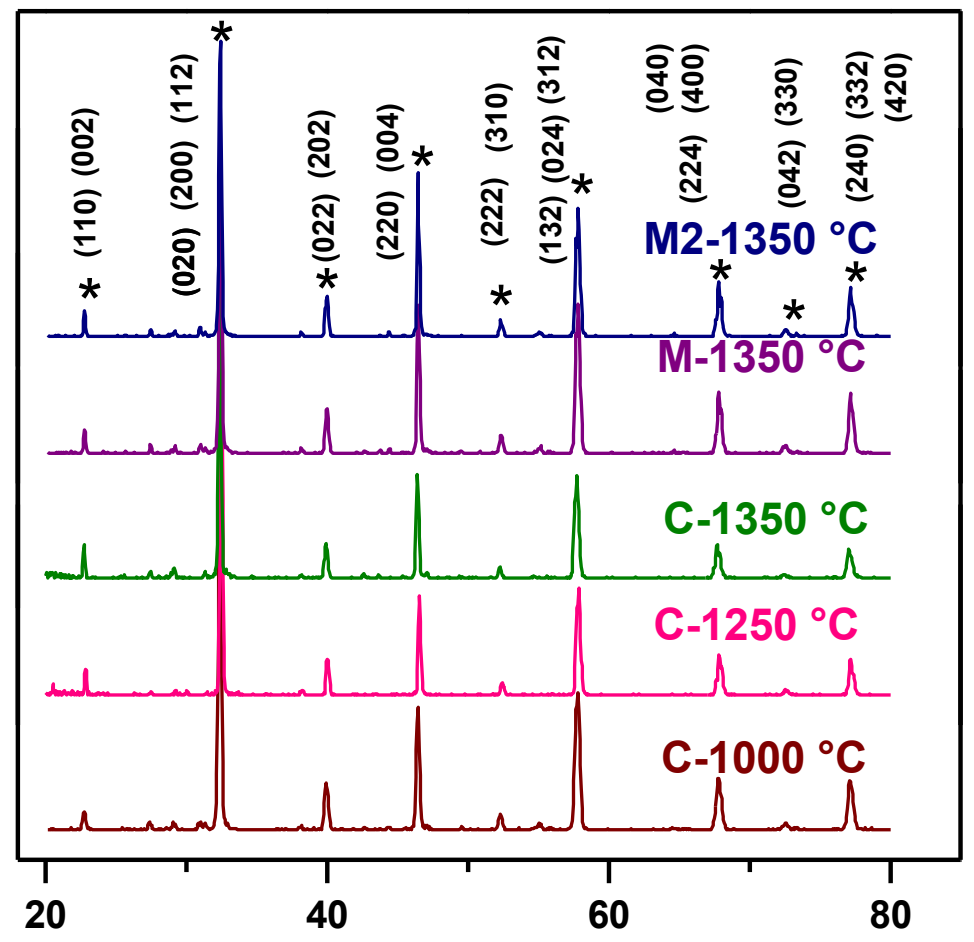

$2 \theta$ (grau)

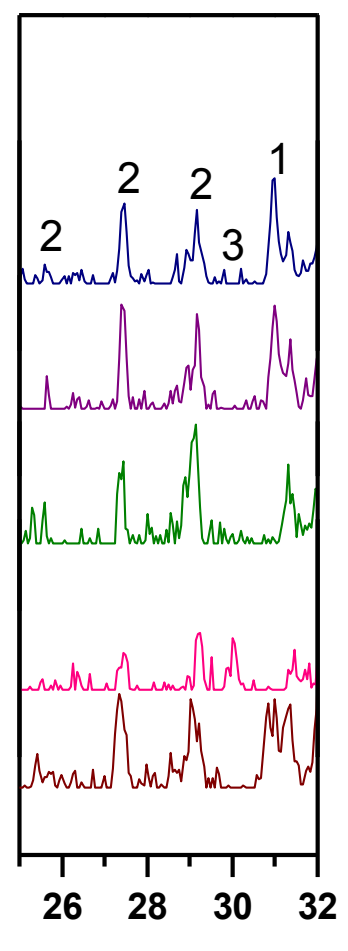

$2 \theta$ (grau)

Figura 20: Difratogramas de raios $X$ das pastilhas após sinterização a $1450^{\circ} \mathrm{C} /$ $4 \mathrm{~h}$ para as cinco rotas utilizadas no método de mistura de óxidos na faixa de $2 \theta$ entre (esquerda) 20 e $80^{\circ}$ e (direita) 25 e 32ㅇ - $\left(^{*}\right)$ LSGM, (1) SrLaGaO (2) $\mathrm{La}_{4} \mathrm{Ga}_{2} \mathrm{O}_{9}$ e (3) $\mathrm{SrLaGa}_{3} \mathrm{O}_{7}$.

Todas as rotas utilizadas exibem a fase ortorrômbica do LSGM [43] e pequenas quantidades de fases secundárias. Embora não tenha sido determinada quantitativamente a fração de cada fase, os difratogramas foram normalizados de modo a permitir uma avaliação destas frações por meio das intensidades relativas. P. Datta e colaboradores estimaram o teor de fases secundárias normalizando os picos de maior intensidade das fases secundárias sobre a intensidade integrada do pico de maior intensidade [23].

Dessa forma, pode-se dizer que as amostras com calcinações sucessivas a $1250{ }^{\circ} \mathrm{C}$ apresentam menores teores de fases secundárias. Entretanto, apresenta maior teor da fase $\mathrm{SrLaGa}_{3} \mathrm{O}_{7}$. Isso pode estar relacionado com o fato de que nessa rota os pós foram calcinados na temperatura $1250{ }^{\circ} \mathrm{C}$ e esta ser favorável à formação desta fase. Nestas 
condições de sinterização (1450 ${ }^{\circ} \mathrm{C} / 4 \mathrm{~h}$ ) não foi possível eliminar as fases secundárias, especificamente $\mathrm{SrLaGaO}_{4}, \mathrm{La}_{4} \mathrm{Ga}_{2} \mathrm{O}_{9}$ e $\mathrm{SrLaGa}_{3} \mathrm{O}_{7}$. Para tentar minimizar a formação das fases secundárias foram realizadas diversas sinterizações pelo método convencional variando as temperaturas e tempos de patamar para as cinco rotas utilizadas.

As Figuras 21 e 22 mostram difratogramas de raios $X$ para amostras com calcinações sucessivas a $1000^{\circ} \mathrm{C}$ sinterizadas em diversas temperaturas com tempo de patamar fixo em $2 \mathrm{~h}$ e com a temperatura fixa de $1450^{\circ} \mathrm{C}$ variando $\mathrm{o}$ tempo de patamar, respectivamente.
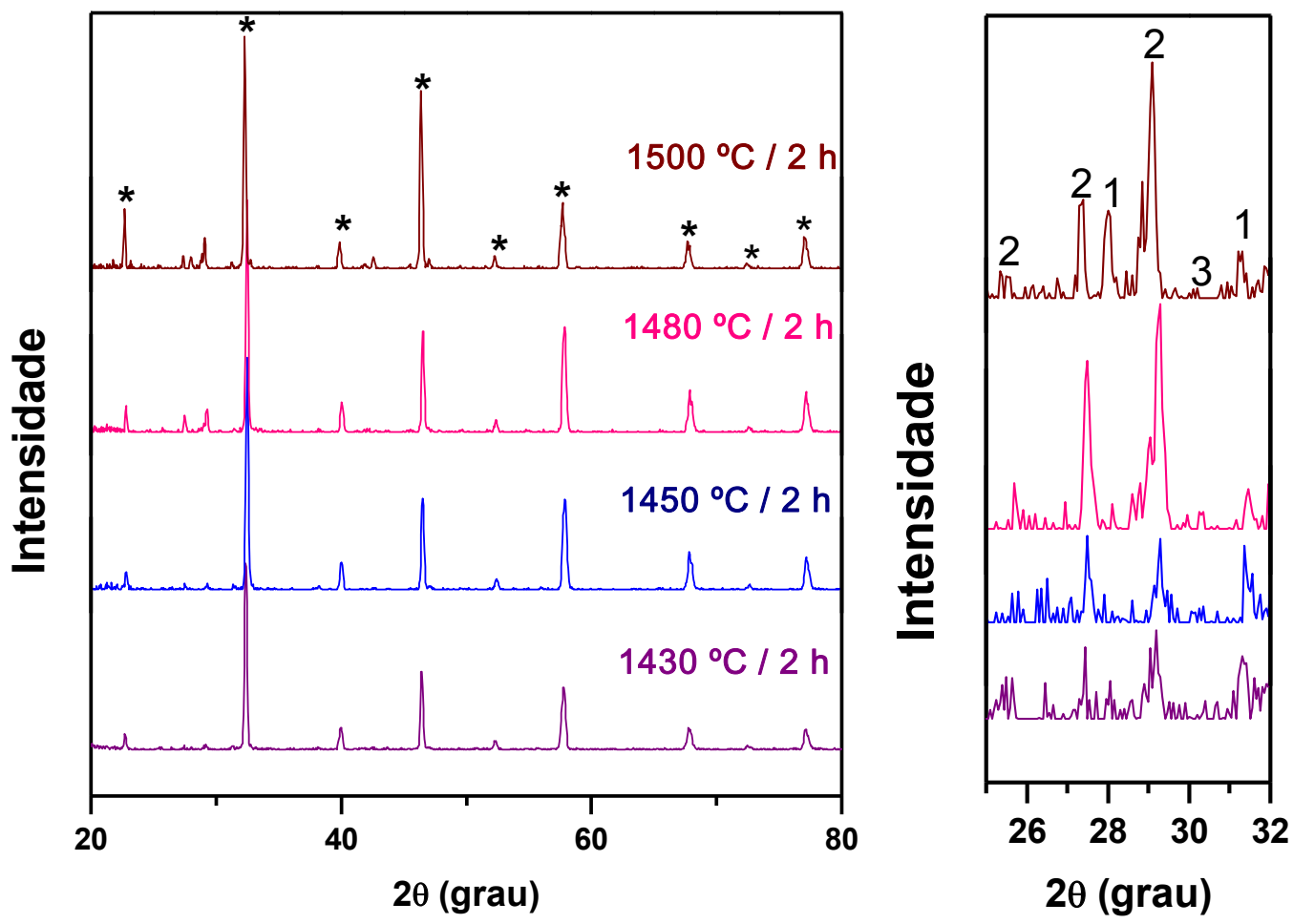

Figura 21: Difratogramas de raios $X$ das pastilhas com calcinações sucessivas a $1000{ }^{\circ} \mathrm{C}$ variando a temperatura de sinterização com tempo de patamar fixo de $2 \mathrm{~h}$ na faixa de $2 \theta$ entre (esquerda) 20 e $80^{\circ}$ e (direita) 25 e $32^{\circ}-\left(^{*}\right)$ LSGM, (1) $\mathrm{SrLaGaO}_{4}$,(2) $\mathrm{La}_{4} \mathrm{Ga}_{2} \mathrm{O}_{9}$ e (3) $\mathrm{SrLaGa}_{3} \mathrm{O}_{7}$. 

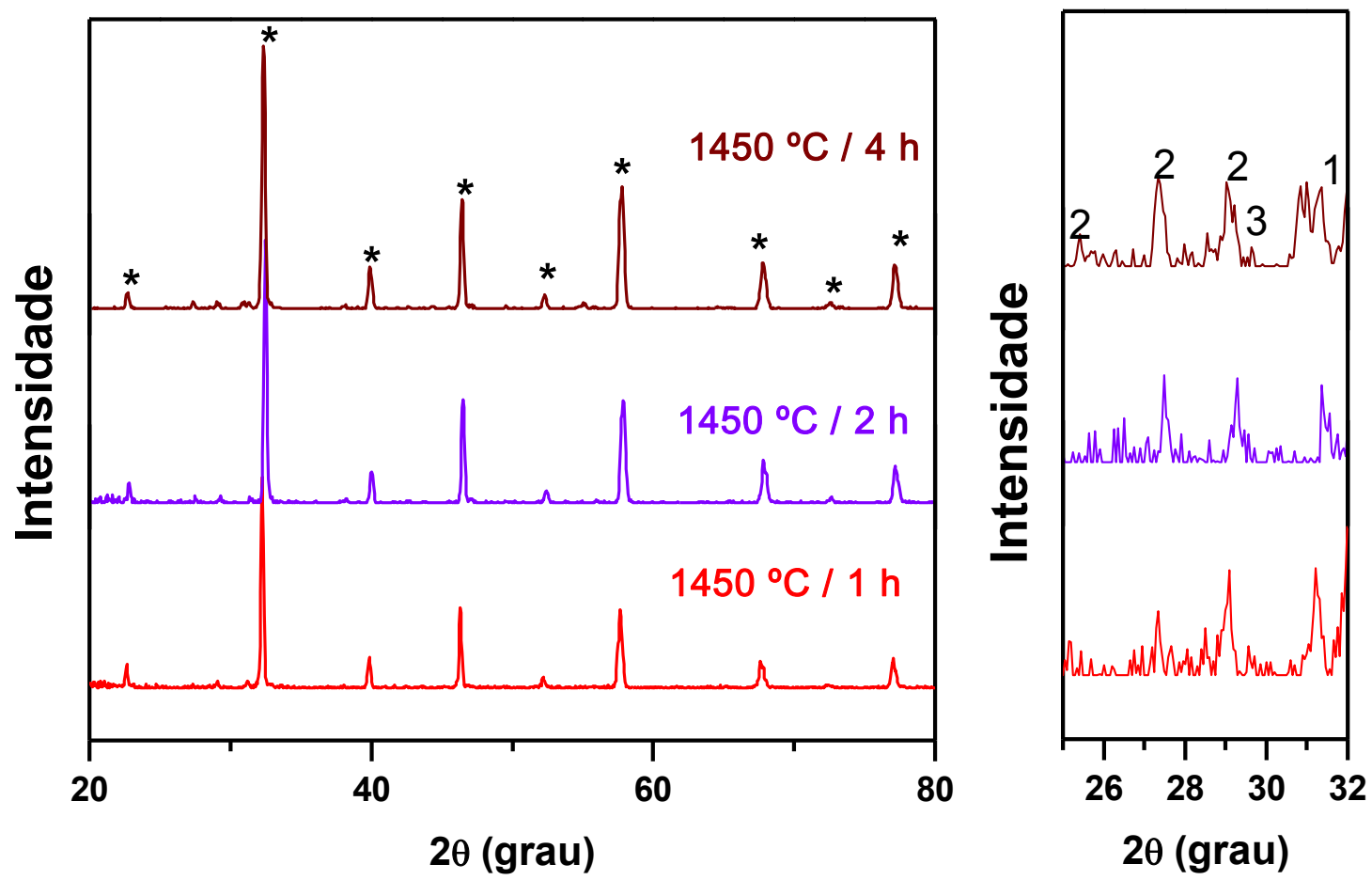

Figura 22: Difratogramas de raios $X$ das pastilhas com calcinações sucessivas a $1000{ }^{\circ} \mathrm{C}$ variando o tempo de patamar com temperatura fixa de $1450{ }^{\circ} \mathrm{C}$ na faixa de $2 \theta$ entre (esquerda) 20 e $80^{\circ}$ e (direita) 25 e $\left.32^{\circ}-{ }^{*}\right)$ LSGM, (1) $\mathrm{SrLaGaO}_{4}$, (2) $\mathrm{La}_{4} \mathrm{Ga}_{2} \mathrm{O}_{9}$ e (3) $\mathrm{SrLaGa}_{3} \mathrm{O}_{7}$.

Para todas as condições de sinterização são observados picos referentes a fase ortorrômbica do LSGM e picos de difração das fases secundárias $\mathrm{SrLaGaO}_{4}, \mathrm{La}_{4} \mathrm{Ga}_{2} \mathrm{O}_{9}$ e $\mathrm{SrLaGa}_{3} \mathrm{O}_{7}$. Com o aumento da temperatura ocorre um aumento significativo na intensidade dos picos de difração das fases $\mathrm{SrLaGaO}_{4}$ e $\mathrm{La}_{4} \mathrm{Ga}_{2} \mathrm{O}_{9}$. O aumento do tempo de patamar, promoveu um aumento do teor das fases $\mathrm{SrLaGaO}_{4}$ e $\mathrm{La}_{4} \mathrm{Ga}_{2} \mathrm{O}_{9}$.

A fase $\mathrm{SrLaGa}_{3} \mathrm{O}_{7}$ também foi obtida por Slater e colaboradores [40] para amostras calcinadas a $1000{ }^{\circ} \mathrm{C}$ e sinterizadas a $1500{ }^{\circ} \mathrm{C} / 6$ h. T. Ishihara e colaboradores reportaram resultados similares [8].

As Figuras 23 e 24 mostram difratogramas de raios $X$ para amostras com calcinações sucessivas a $1250{ }^{\circ} \mathrm{C}$ e sinterizadas em diversas temperaturas, com tempo de patamar fixo em $2 \mathrm{~h}$ e com a temperatura fixa de $1450{ }^{\circ} \mathrm{C}$ variando o tempo de patamar, respectivamente. 

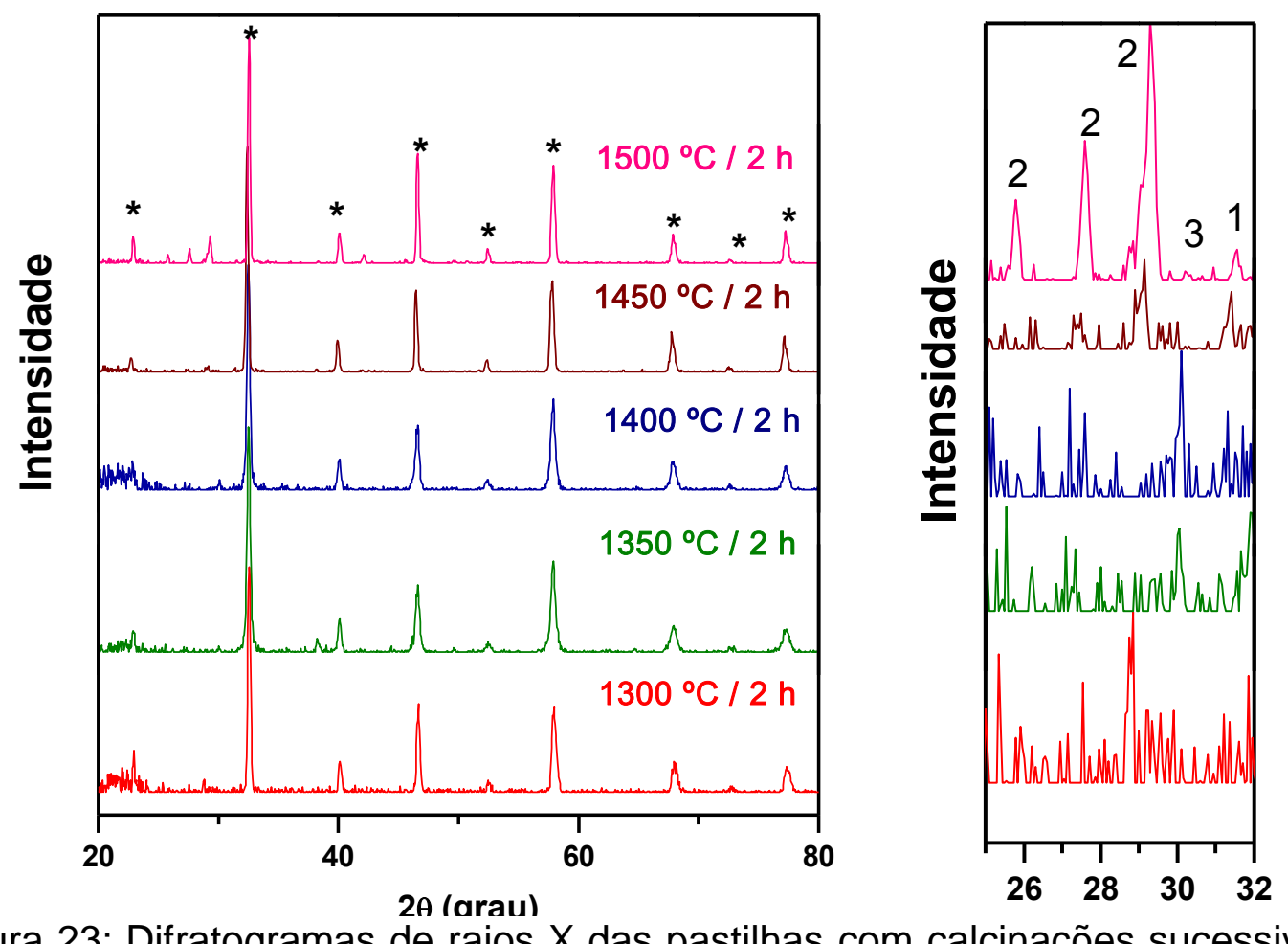

Figura 23: Difratogramas de raios $X$ das pastilhas com calcinações sucessivas a $1250{ }^{\circ} \mathrm{C}$ variando a temperatura de sinterização com tempo de patamar fixo de $2 \mathrm{~h}$ na faixa de $2 \theta$ entre (esquerda) 20 e $80^{\circ}$ e (direita) 25 e $32^{\circ}$ ( $^{*}$ ) LSGM, (1) $\mathrm{SrLaGaO}_{4}$, (2) $\mathrm{La}_{4} \mathrm{Ga}_{2} \mathrm{O}_{9}$ e (3) $\mathrm{SrLaGa}_{3} \mathrm{O}_{7}$.
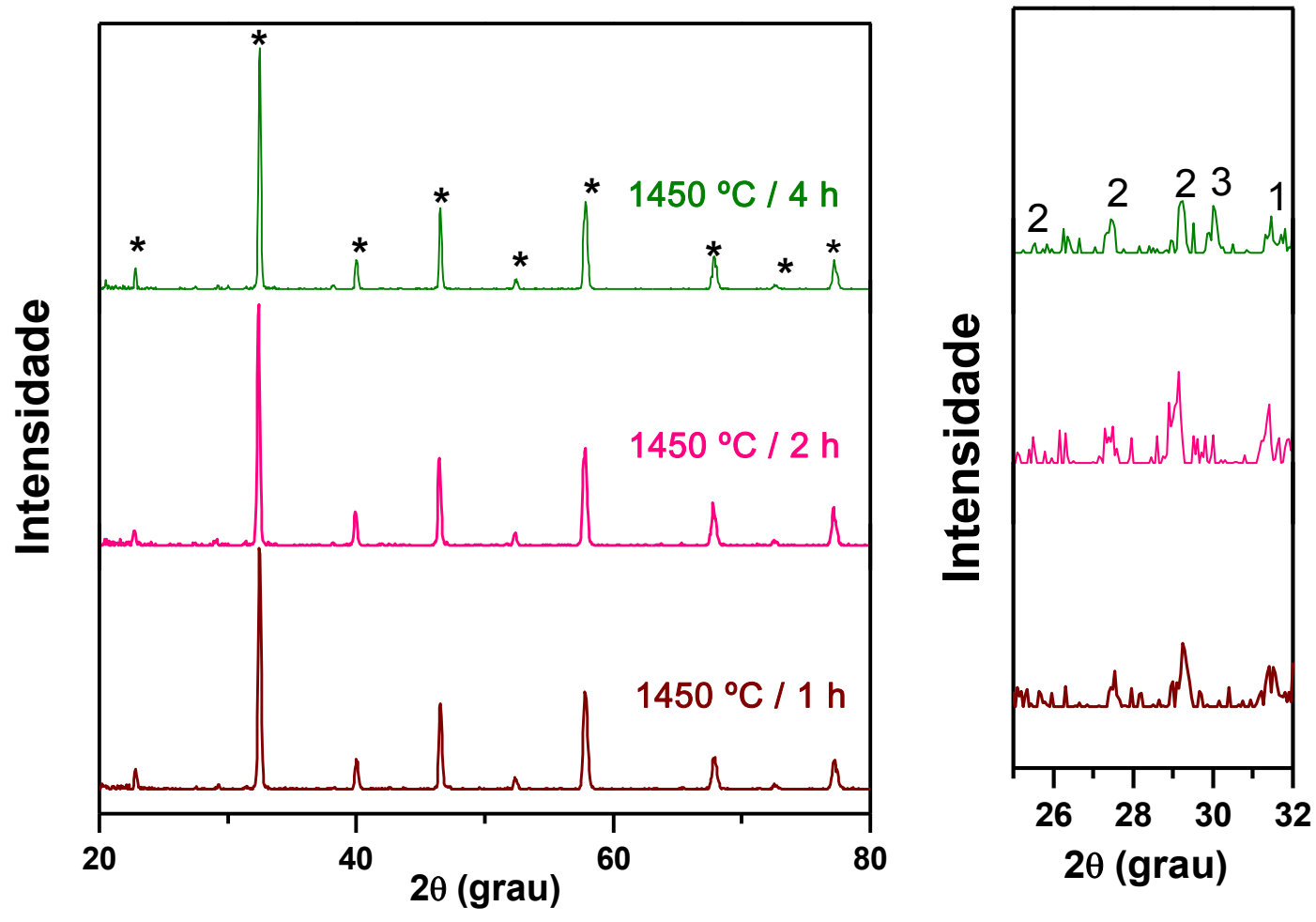

Figura 24: Difratogramas de raios $X$ das pastilhas com calcinações sucessivas a $1250{ }^{\circ} \mathrm{C}$ variando o tempo de patamar com temperatura fixa de $1450 \stackrel{\circ}{\circ} \mathrm{C}$ na faixa de $2 \theta$ entre (esquerda) 20 e $80^{\circ}$ e (direita) 25 e $32^{\circ}-\left(^{*}\right)$ LSGM, (1) $\mathrm{SrLaGaO}_{4}$, (2) $\mathrm{La}_{4} \mathrm{Ga}_{2} \mathrm{O}_{9}$ e (3) $\mathrm{SrLaGa}_{3} \mathrm{O}_{7}$. 
Temperaturas elevadas, maiores que $1450{ }^{\circ} \mathrm{C}$, promoveram aumento na quantidade de fases secundárias principalmente $\mathrm{La}_{4} \mathrm{Ga}_{2} \mathrm{O}_{9}$, e a diminuição da fase $\mathrm{SrLaGa}_{3} \mathrm{O}_{7}$. Tempos mais longos causam aumento na fração da fase $\mathrm{SrLaGa}_{3} \mathrm{O}_{7}$ e diminuição das demais fases secundárias.

As Figuras 25 e 26 mostram difratogramas de raios $X$ para amostras com calcinações sucessivas a $1350{ }^{\circ} \mathrm{C}$ e sinterizadas em diversas temperaturas, com tempo de patamar fixo em $2 \mathrm{~h}$ e com a temperatura fixa de $1450{ }^{\circ} \mathrm{C}$ variando o tempo de patamar, respectivamente.
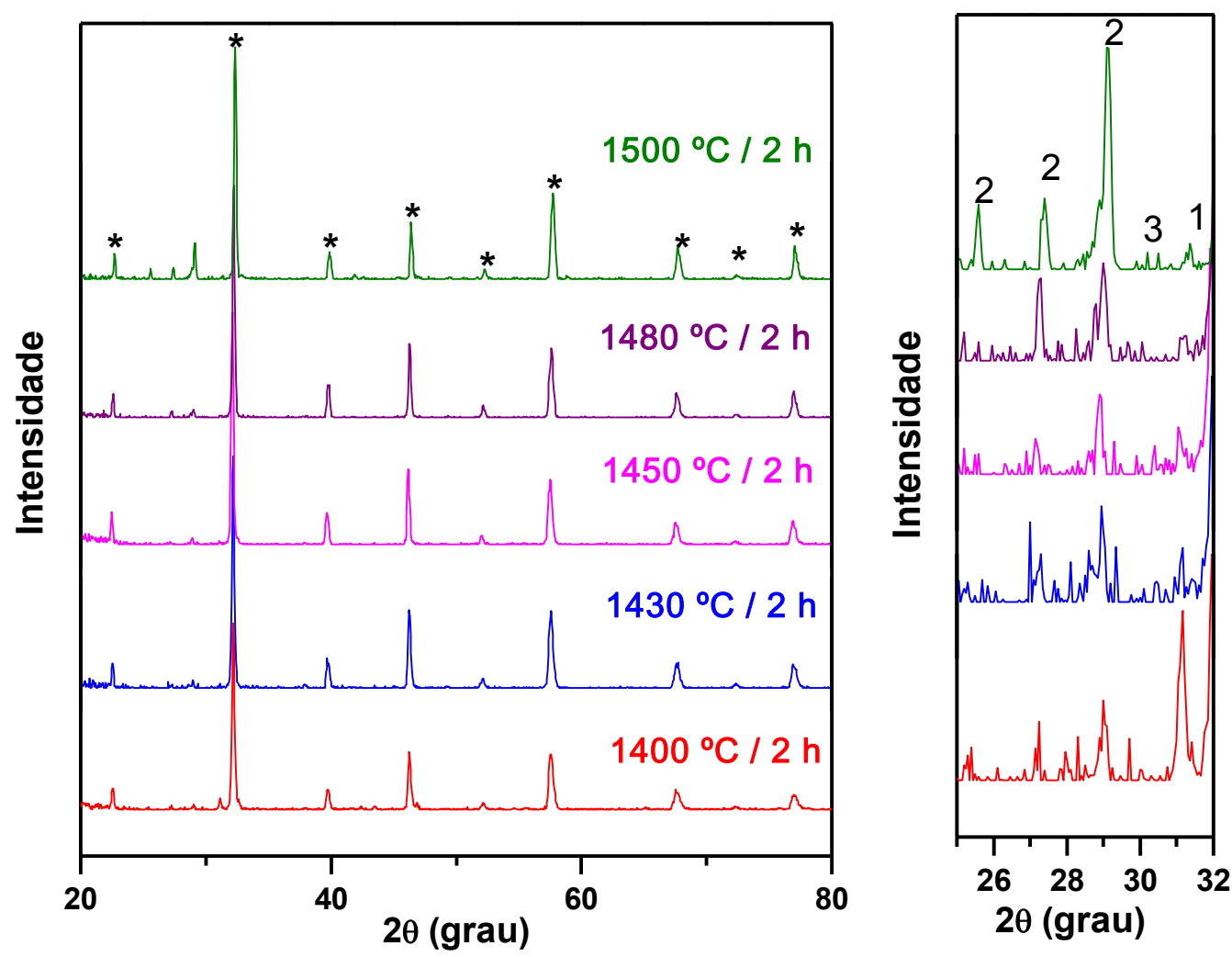

Figura 25: Difratogramas de raios $X$ das pastilhas com calcinações sucessivas a $1350{ }^{\circ} \mathrm{C}$ variando a temperatura de sinterização com tempo de patamar fixo de $2 \mathrm{~h}$ na faixa de $2 \theta$ entre (esquerda) 20 e $80^{\circ}$ e (direita) 25 e $32^{\circ}\left(^{*}\right)$ LSGM, (1) $\mathrm{SrLaGaO}_{4}$,(2) $\mathrm{La}_{4} \mathrm{Ga}_{2} \mathrm{O}_{9}$ e (3) $\mathrm{SrLaGa}_{3} \mathrm{O}_{7}$. 

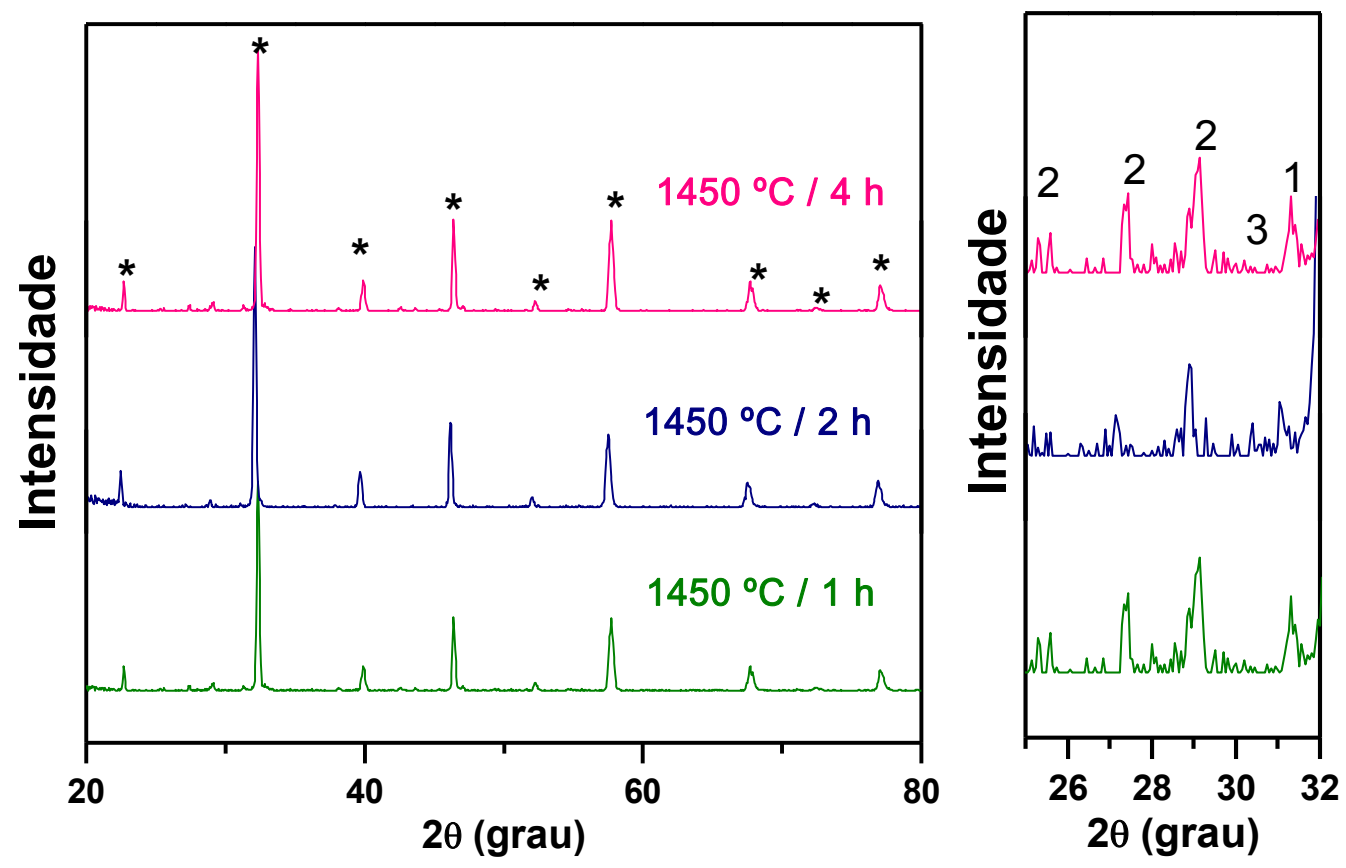

Figura 26: Difratogramas de raios $X$ das pastilhas com calcinações sucessivas a $1350{ }^{\circ} \mathrm{C}$ variando o tempo de patamar com temperatura fixa de $1450{ }^{\circ} \mathrm{C}$ na faixa de $2 \theta$ entre (esquerda) 20 e $80^{\circ}$ e (direita) 25 e $32^{\circ}-\left(^{*}\right)$ LSGM, (1) $\mathrm{SrLaGaO}_{4}$, (2) $\mathrm{La}_{4} \mathrm{Ga}_{2} \mathrm{O}_{9}$ e (3) $\mathrm{SrLaGa}_{3} \mathrm{O}_{7}$.

Para todas as condições de sinterização são observados picos referentes à fase ortorrômbica do LSGM e picos de difração das fases secundárias $\mathrm{SrLaGaO}_{4}, \mathrm{La}_{4} \mathrm{Ga}_{2} \mathrm{O}_{9}$ e $\mathrm{SrLaGa}_{3} \mathrm{O}_{7}$. Neste caso, aumentando-se a temperatura de sinterização aumentou o teor da fase $\mathrm{La}_{4} \mathrm{Ga}_{2} \mathrm{O}_{9}$ e diminuiu o teor das fases $\mathrm{SrLaGaO}_{4}$ e SrLaGa $\mathrm{O}_{7}$. O aumento do tempo de patamar não promoveu alterações significativas na intensidade dos picos de difração das fases secundárias.

As Figuras 27 e 28 mostram difratogramas de raios $X$ para amostras com uma calcinação a $1350^{\circ} \mathrm{C}$ com moagens intercaladas e sinterizadas em diversas temperaturas, com tempo de patamar fixo em $2 \mathrm{~h}$ e com a temperatura fixa de $1450{ }^{\circ} \mathrm{C}$ variando o tempo de patamar, respectivamente. 

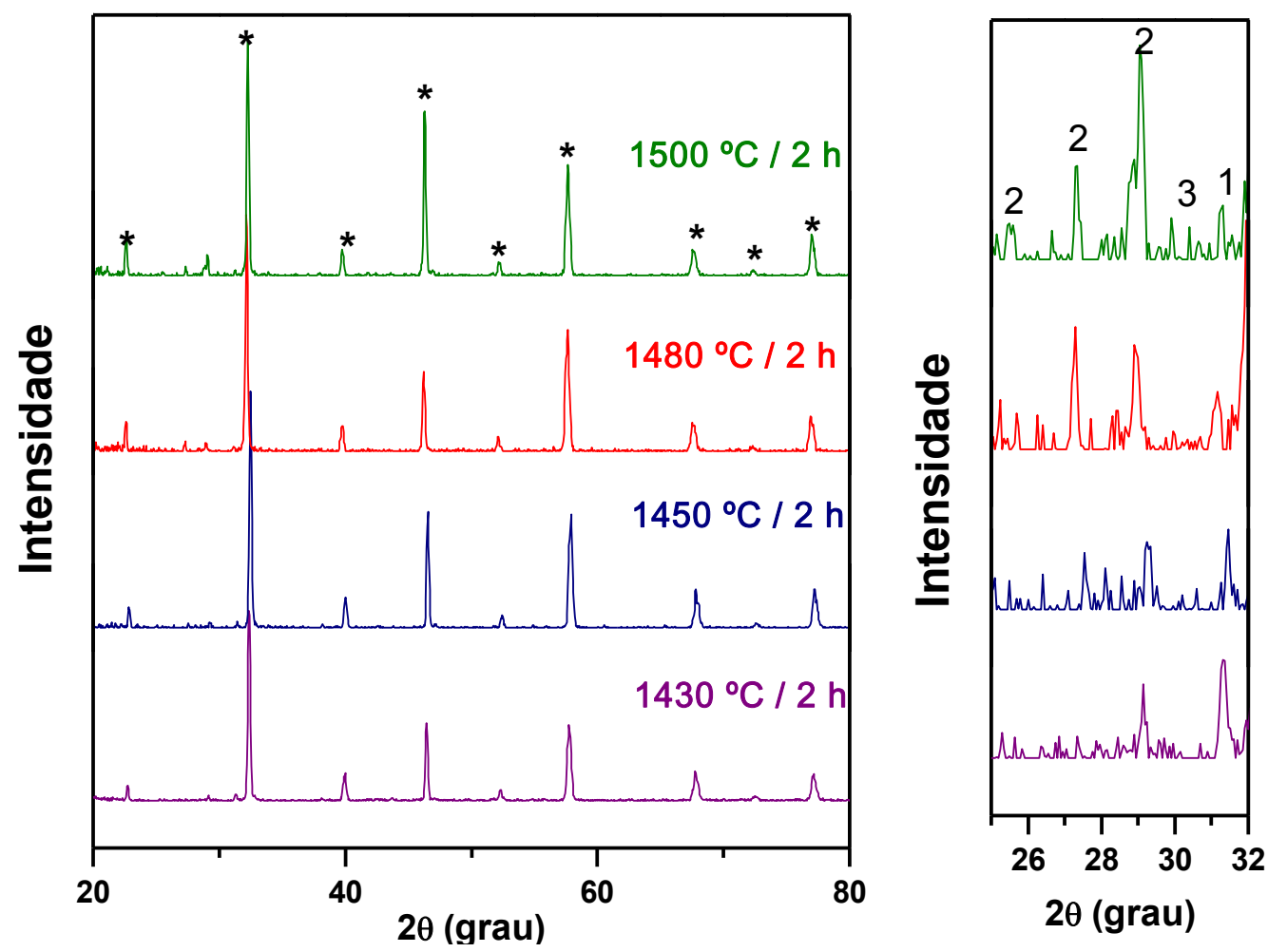

Figura 27: Difratogramas de raios $X$ das pastilhas com uma calcinação a $1350{ }^{\circ} \mathrm{C}$ com moagens intercaladas variando a temperatura de sinterização com tempo de patamar fixo de $2 \mathrm{~h}$ na faixa de $2 \theta$ entre (esquerda) 20 e $80^{\circ}$ e (direita) 25 e 32ㅇ - (*) LSGM, (1) $\mathrm{SrLaGaO}_{4}$, (2) $\mathrm{La}_{4} \mathrm{Ga}_{2} \mathrm{O}_{9}$ e (3) $\mathrm{SrLaGa}_{3} \mathrm{O}_{7}$.
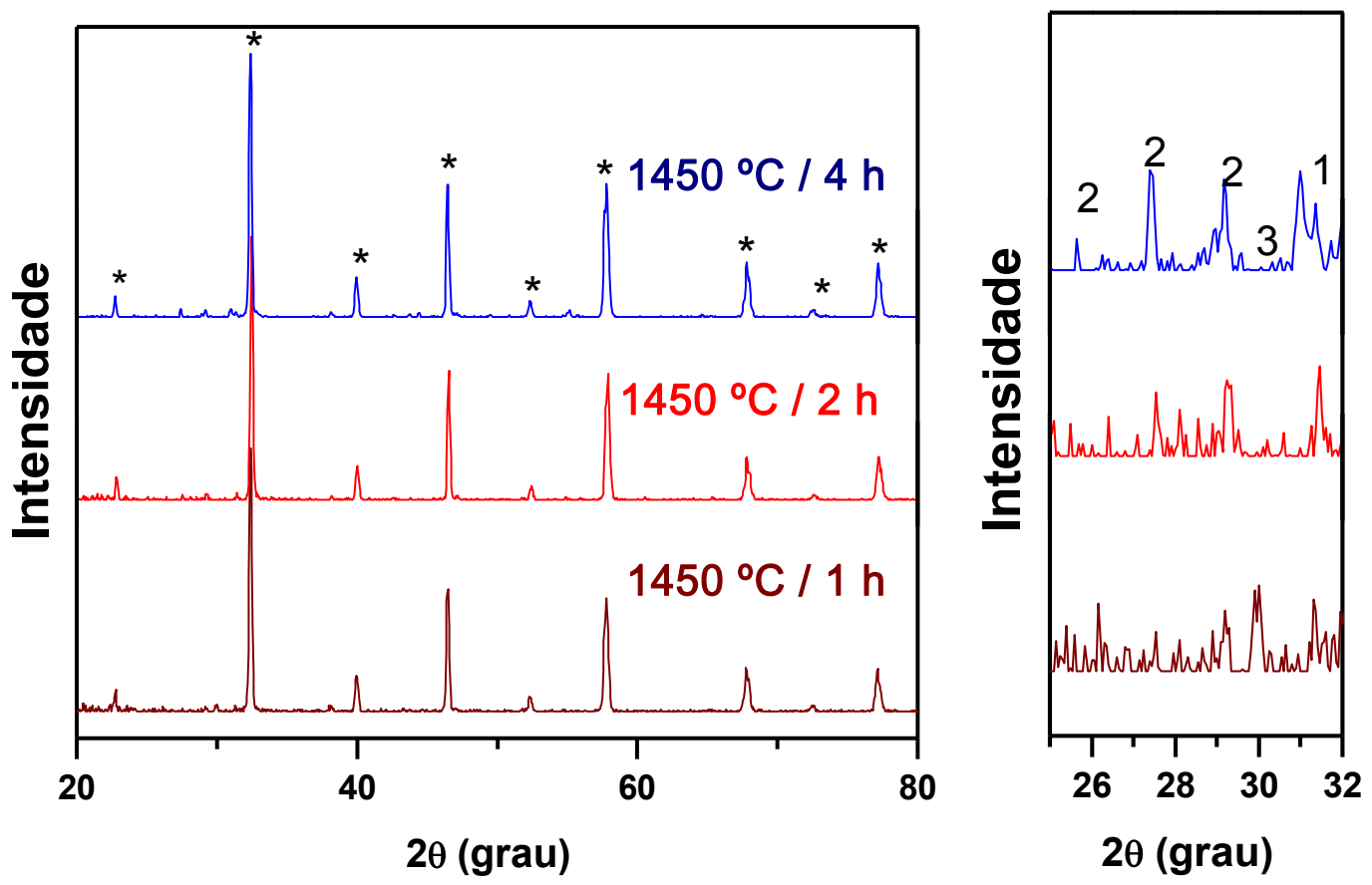

Figura 28: Difratogramas de raios $X$ das pastilhas com uma calcinação a $1350{ }^{\circ} \mathrm{C}$ com moagens intercaladas variando o tempo de patamar com temperatura fixa de $1450{ }^{\circ} \mathrm{C}$ na faixa de $2 \theta$ entre (esquerda) 20 e $80^{\circ}$ e (direita) 25 e $32^{\circ}-\left(^{*}\right) \mathrm{LSGM},(1) \mathrm{SrLaGaO}_{4},(2) \mathrm{La}_{4} \mathrm{Ga}_{2} \mathrm{O}_{9}$ e (3) $\mathrm{SrLaGa}_{3} \mathrm{O}_{7}$. 
As amostras obtidas com uma calcinação a $1350{ }^{\circ} \mathrm{C}$ com moagens intercaladas, apresentaram picos referentes as fases secundárias $\mathrm{SrLaGaO}_{4}$, $\mathrm{La}_{4} \mathrm{Ga}_{2} \mathrm{O}_{9}$ e SrLaGa $\mathrm{O}_{7}$. Neste caso, aumentando-se a temperatura de sinterização aumentaram os teores das fases $\mathrm{La}_{4} \mathrm{Ga}_{2} \mathrm{O}_{9}$ e $\mathrm{SrLaGa}_{3} \mathrm{O}_{7}$ e diminuiu o teor da fase $\mathrm{SrLaGaO}_{4}$. O aumento do tempo de patamar promoveu o aumento dos teores das fases $\mathrm{SrLaGaO}_{4}$ e $\mathrm{La}_{4} \mathrm{Ga}_{2} \mathrm{O}_{9}$ e diminuição dos picos de difração da fase $\mathrm{SrLaGa}_{3} \mathrm{O}_{7}$.

As Figuras 29 e 30 mostram difratogramas de raios $X$ para amostras com duas calcinações a $1350^{\circ} \mathrm{C}$ com moagens intercaladas e sinterizadas em diversas temperaturas, com tempo de patamar fixo em $2 \mathrm{~h}$ e com a temperatura fixa de $1450^{\circ} \mathrm{C}$ variando o tempo de patamar, respectivamente.
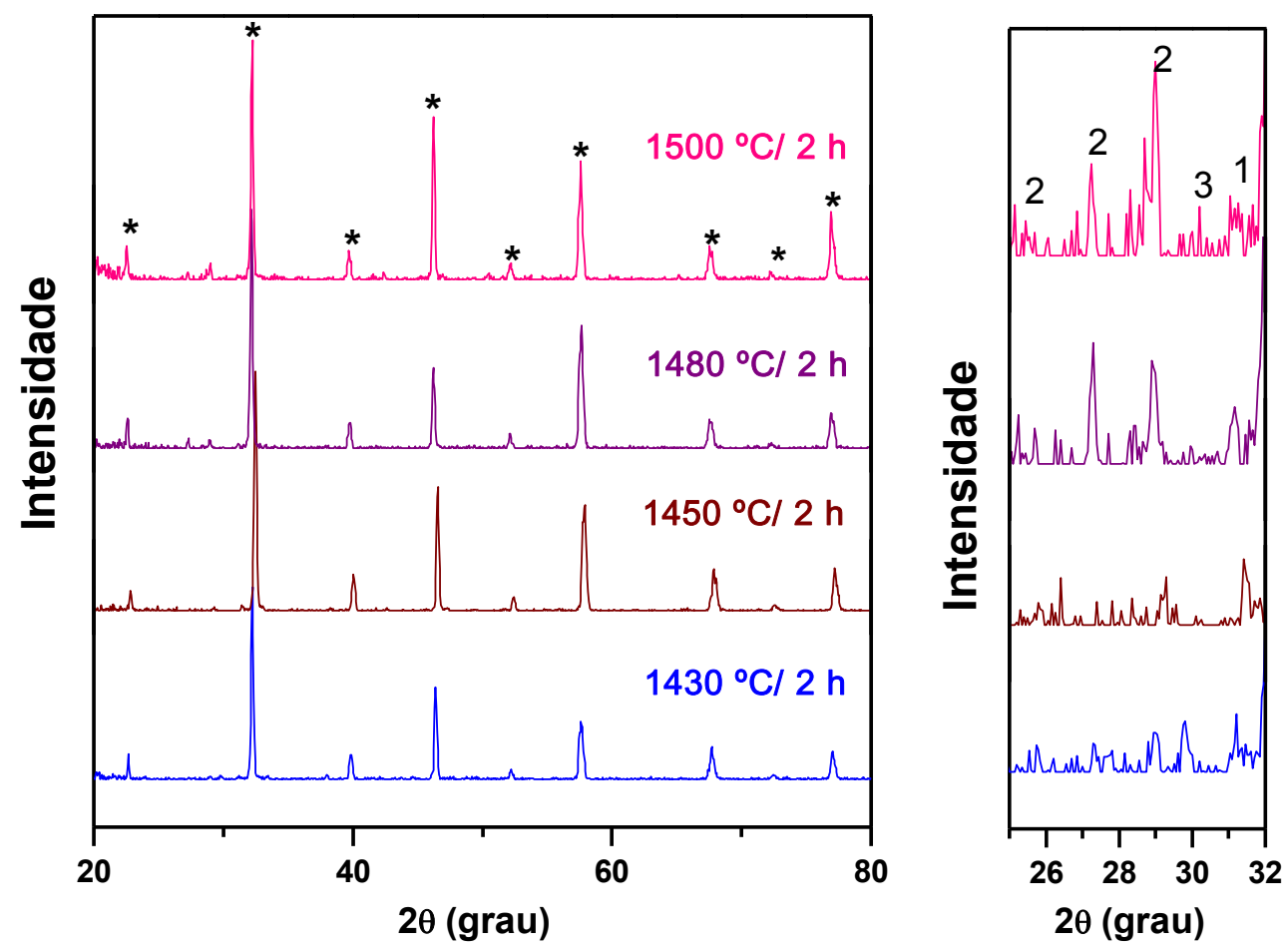

Figura 29: Difratogramas de raios $X$ das pastilhas com duas calcinações a $1350{ }^{\circ} \mathrm{C}$ com moagens intercaladas variando a temperatura de sinterização com tempo de patamar fixo de $2 \mathrm{~h}$ na faixa de $2 \theta$ entre (esquerda) 20 e $80^{\circ}$ e (direita) 25 e 32ㅇ - (*) LSGM, (1) $\mathrm{SrLaGaO}_{4}$, (2) $\mathrm{La}_{4} \mathrm{Ga}_{2} \mathrm{O}_{9}$ e (3) $\mathrm{SrLaGa}_{3} \mathrm{O}_{7}$. 

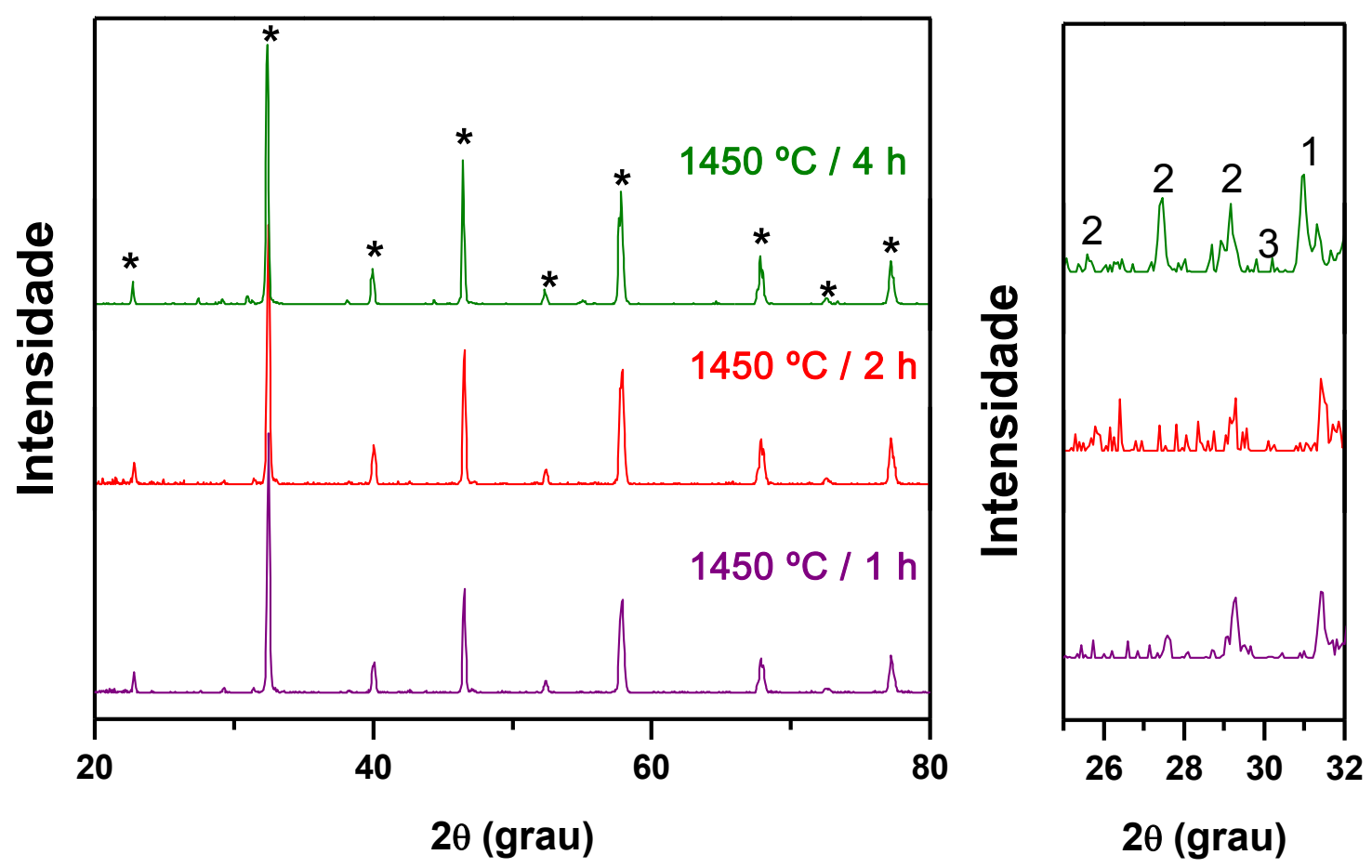

Figura 30: Difratogramas de raios $X$ das pastilhas com duas calcinações a $1350{ }^{\circ} \mathrm{C}$ com moagens intercaladas variando o tempo de patamar com temperatura fixa de $1450{ }^{\circ} \mathrm{C}$ na faixa de $2 \theta$ entre (esquerda) 20 e $80^{\circ}$ e (direita) 25 e $32^{\circ}$ - ( $\left.{ }^{*}\right) \mathrm{LSGM}$, (1) $\mathrm{SrLaGaO}_{4}$, (2) $\mathrm{La}_{4} \mathrm{Ga}_{2} \mathrm{O}_{9}$ e (3) $\mathrm{SrLaGa}_{3} \mathrm{O}_{7}$.

Semelhante às demais rotas, as amostras obtidas com duas calcinações a $1350{ }^{\circ} \mathrm{C}$ com moagens intercaladas apresentaram picos de difração da fase ortorrômbica do LSGM e picos de difração das fases secundárias $\mathrm{SrLaGaO}_{4}$, $\mathrm{La}_{4} \mathrm{Ga}_{2} \mathrm{O}_{9}$ e SrLaGa $\mathrm{O}_{7}$. Neste caso, aumentando-se a temperatura de sinterização aumentou o teor da fase $\mathrm{La}_{4} \mathrm{Ga}_{2} \mathrm{O}_{9}$ e diminuiu o teor da fase $\mathrm{SrLaGaO}_{4}$ e a fase $\mathrm{SrLaGa}_{3} \mathrm{O}_{7}$ não apresentou variação significativa. O aumento do tempo de patamar promoveu um aumento do teor das fases $\mathrm{SrLaGaO}_{4}, \mathrm{La}_{4} \mathrm{Ga}_{2} \mathrm{O}_{9}$ e $\mathrm{SrLaGa}_{3} \mathrm{O}_{7}$.

A Figura 31 mostra difratogramas de raios $X$ para as amostras com calcinações sucessivas a $1250^{\circ} \mathrm{C}$, e obtidas com duas calcinações a $1350^{\circ} \mathrm{C}$ com moagens intercaladas e sinterizadas a $1500^{\circ} \mathrm{C} / 6 \mathrm{~h}$. 


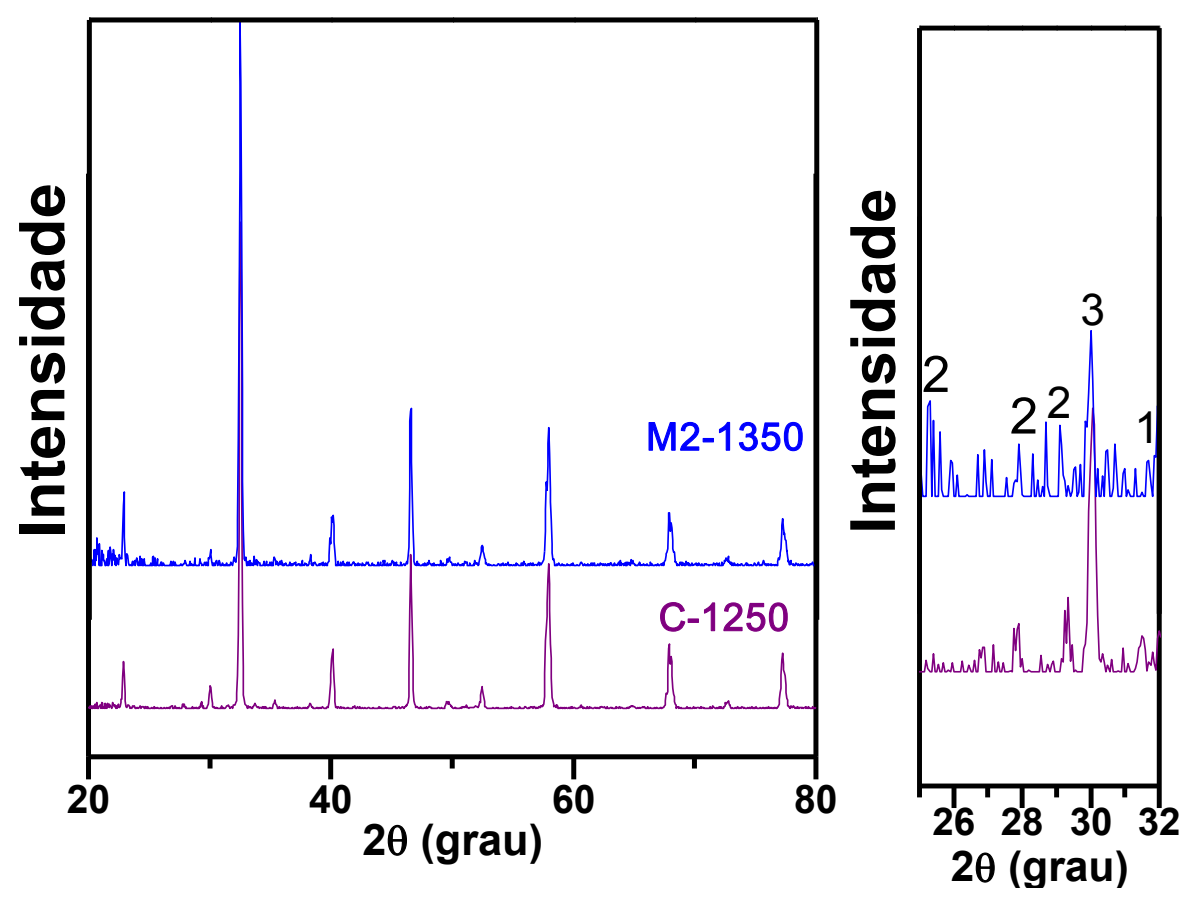

Figura 31: Difratogramas de raios $X$ das pastilhas obtidas com calcinações sucessivas a $1250{ }^{\circ} \mathrm{C}$ e com duas calcinações a $1350{ }^{\circ} \mathrm{C}$ com moagens intercaladas e sinterizadas a $1500{ }^{\circ} \mathrm{C} / 6 \mathrm{~h}$ na faixa de $2 \theta$ entre (esquerda) $20 \mathrm{e}$ $80^{\circ}$ e (direita) 25 e $32^{\circ}$ - (*) LSGM, (1) $\mathrm{SrLaGaO}_{4}$, (2) $\mathrm{La}_{4} \mathrm{Ga}_{2} \mathrm{O}_{9}$ e (3) $\mathrm{SrLaGa}_{3} \mathrm{O}_{7}$

Para amostras com calcinações sucessivas a $1250{ }^{\circ} \mathrm{C}$, temperaturas elevadas e maiores tempos de patamar promoveram o aumento no teor da fase $\mathrm{SrLaGa}_{3} \mathrm{O}_{7}$, e um comparativamente pequeno aumento na fração da fase $\mathrm{La}_{4} \mathrm{Ga}_{2} \mathrm{O}_{9}$. O mesmo fenômeno é observado para as amostras preparadas com duas calcinações a $1350^{\circ} \mathrm{C}$ com moagens intercaladas. Assim, o aumento no tempo de patamar favorece a formação da fase $\mathrm{SrLaGa}_{3} \mathrm{O}_{7}$.

Esses resultados permitem concluir que nas amostras preparadas pelo método de misturas de óxidos, foi possível obter a fase ortorrômbica do LSGM, mas não foi possível eliminar as fases $\mathrm{SrLaGaO}_{4}, \mathrm{La}_{4} \mathrm{Ga}_{2} \mathrm{O}_{9}$ e $\mathrm{SrLaGa}_{3} \mathrm{O}_{7}$ independente das condições de sinterização utilizadas.

Entretanto, a existência e a intensidade das fases secundárias são influenciadas pelas etapas de calcinação e moagens realizadas em cada rota.

E. Djurado e M. Labeau mostraram que a condição $1500^{\circ} \mathrm{C} / 6 \mathrm{~h}$ seria uma condição ideal para obter o LSGM com fase única e tempos longos ocorre uma deterioração das purezas das fases [11]. Y-Chun Wu e colaboradores 
reportaram que o LSGM calcinado a $1250{ }^{\circ} \mathrm{C} / 5 \mathrm{~h}$ e sinterizado a $1500{ }^{\circ} \mathrm{C} / 10 \mathrm{~h}$ contem a fase $\mathrm{SrLaGa}_{3} \mathrm{O}_{7}$ [47].

Diversos autores mostraram a dificuldade em obter o LSGM sem fases secundárias pelo método de mistura de óxidos independentemente das etapas de calcinação e sinterização empregadas [23, 29, 42, 50].

Para verificar se as fases presentes nas amostras não são apenas superficiais, foi realizada medida de difração de raios $X$ na superfície das amostras com duas calcinações a $1350^{\circ} \mathrm{C}$ com moagens intercaladas antes e após o lixamento da superfície de uma camada de aproximadamente $100 \mu \mathrm{m}$ para amostras sinterizadas a $1450 \stackrel{\circ}{\circ} / 4$ h, Figura 32.

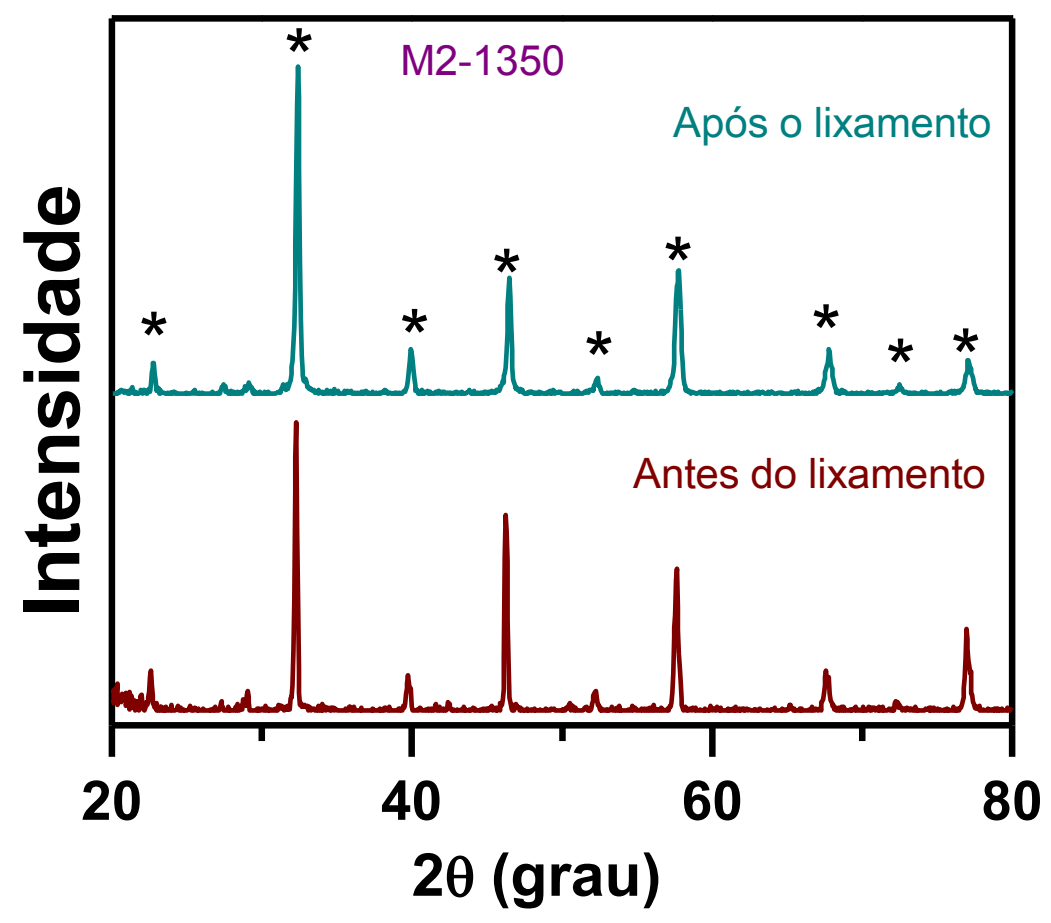

Figura 32: Difratogramas de raios $X$ das pastilhas obtidas com duas calcinações a $1350^{\circ} \mathrm{C}$ com moagens intercaladas antes e após o lixamento, sinterizadas a $1450^{\circ} \mathrm{C} / 4 \mathrm{~h}$.

Após a remoção de $100 \mu \mathrm{m}$ foram detectadas a fase ortorrômbica do LSGM e as demais fases secundárias, ou seja, esses resultados mostram que essas fases não são apenas superficiais. O LSGM não está apenas na superfície das amostras, isso mostra que as moagens e temperaturas utilizadas foram efetivas para obter a fase LSGM homogeneamente. 
A Figura 33 mostra os difratogramas de raios $X$, das amostras preparadas pelo método de complexação de cátions variando a temperatura de sinterização com tempo de patamar fixo de $4 \mathrm{~h}$.

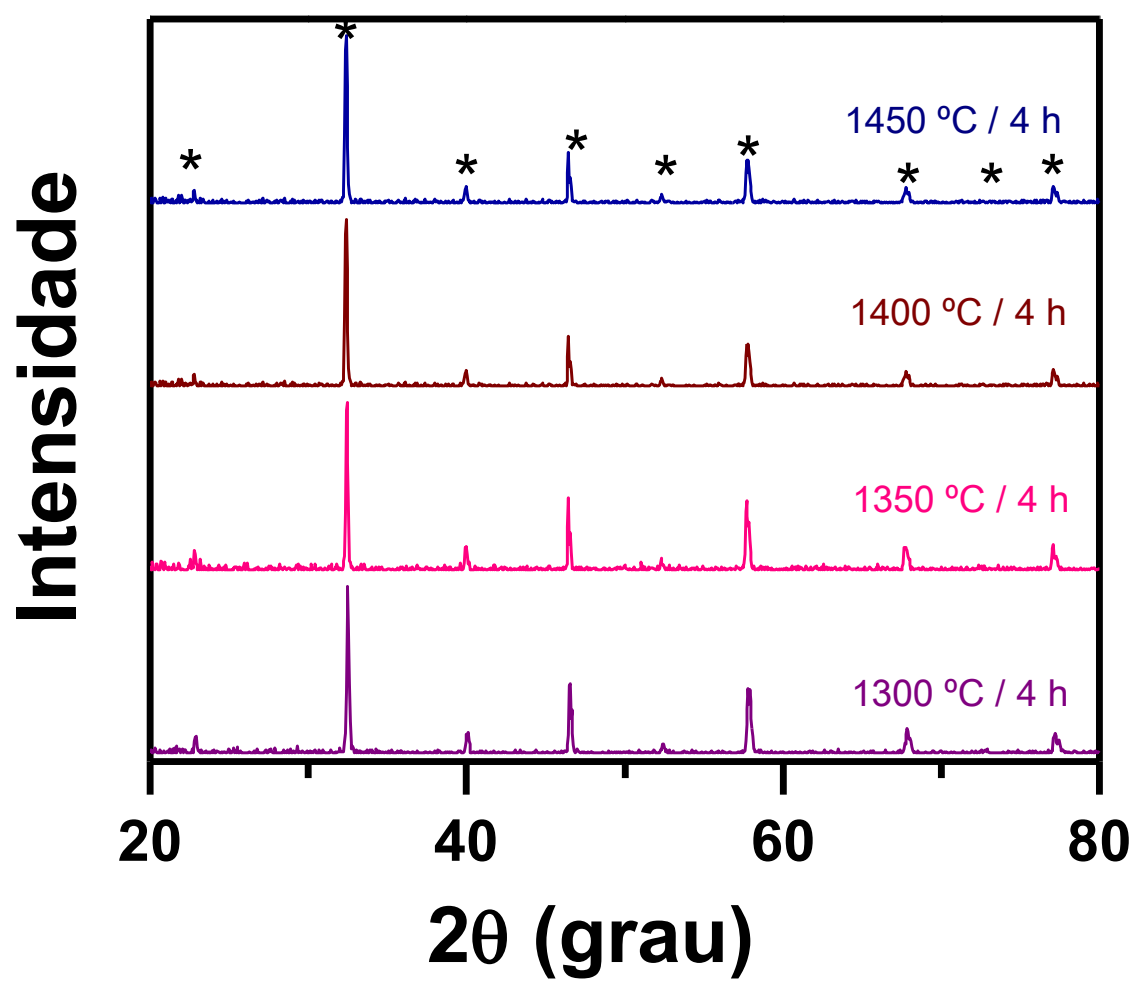

Figura 33: Difratogramas de raios $\mathrm{X}$ das pastilhas obtidas pelo método de complexação de cátions variando a temperatura de patamar com tempo de patamar fixo de $4 \mathrm{~h} .\left(^{*}\right)$ LSGM.

Para as amostras preparadas pelo método de complexação de cátions, aparentemente foi possível obter a fase do LSGM sem fases secundárias a partir da temperatura de sinterização de $1300^{\circ} \mathrm{C}$. Desta forma, a partir desses resultados, para a verificação da estabilidade de fase do LSGM foram realizadas algumas sinterizações variando o tempo de patamar e mantendo a temperatura fixa a $1400^{\circ} \mathrm{C}$.

A Figura 34 mostra os difratogramas de raios $X$ das amostras preparadas pelo método de complexação de cátions, com diferentes tempos de patamar na temperatura de $1400^{\circ} \mathrm{C}$. 


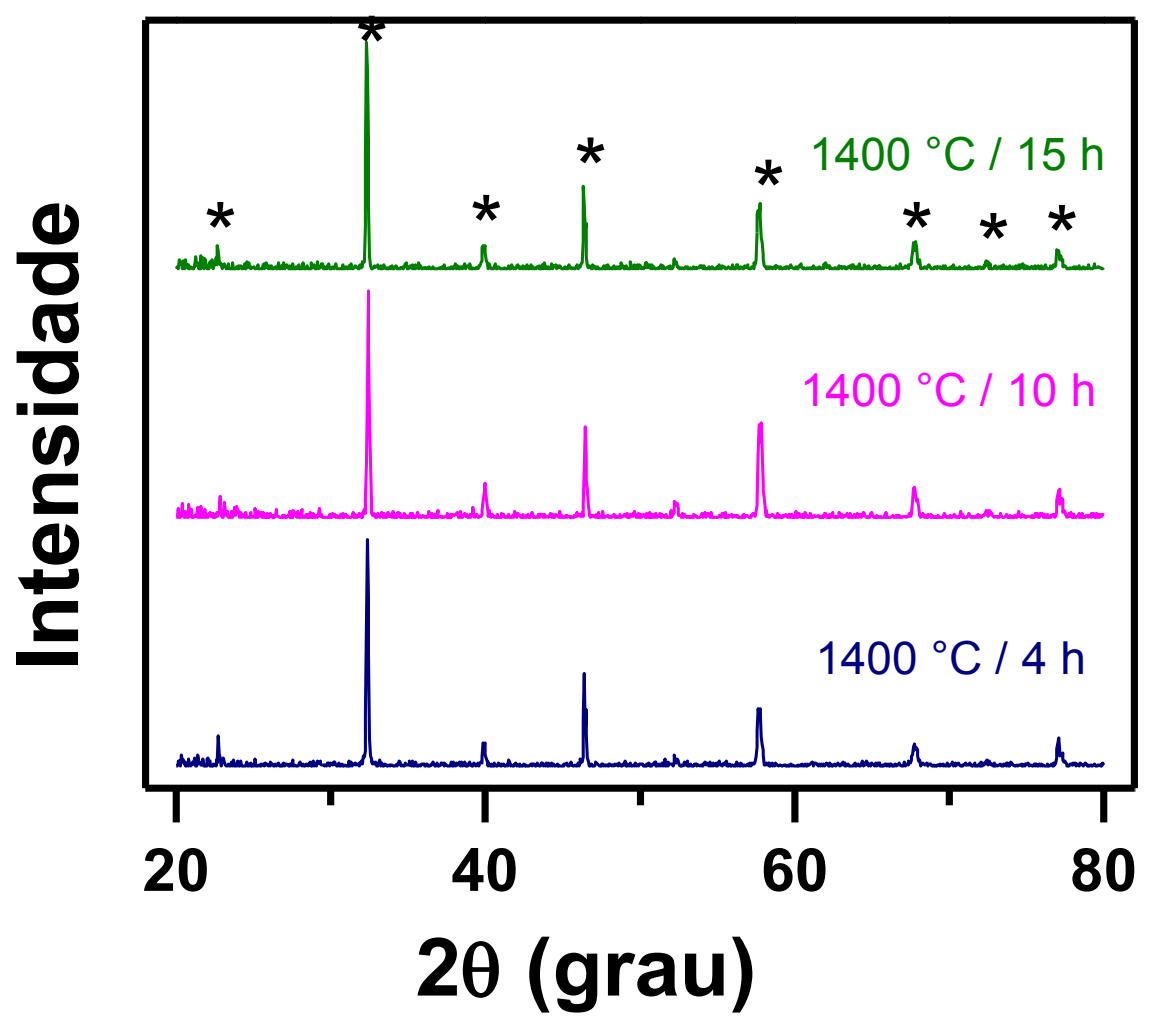

Figura 34: Difratogramas de raios $X$ das pastilhas obtidas pelo método de complexação de cátions variando o tempo de patamar com temperatura fixa de $1400^{\circ} \mathrm{C} .\left(^{*}\right)$ LSGM.

O aumento do tempo de patamar na temperatura de $1400^{\circ} \mathrm{C}$ não deu origem à formação de fases secundárias, dentro da incerteza da técnica utilizada nesse trabalho. R. Polini e colaboradores [79] utilizando o mesmo método químico, também não detectaram picos de fases secundárias por difração de raios $X$, porém com a observação em microscópio eletrônico de varredura confirmaram a formação de grãos de $\mathrm{MgO}$.

A seguir, serão apresentados os resultados de outras caracterizações realizadas tanto para o método de mistura de óxidos como para o método de complexação de cátions, com o objetivo de estudar a influência dessas fases secundárias nas propriedades do LSGM.

\section{Densidade}

A Tabela VII lista as condições de sinterização empregadas na obtenção das amostras obtidas pelo método de mistura de óxidos, e suas respectivas 
densidades. Neste trabalho, a densidade teórica (DT) utilizada foi $6,67 \mathrm{~g}_{\mathrm{cm}} \mathrm{cm}^{-3}$ obtida da ficha ICSD \#51-288 [43].

Tabela VII - Densidade relativa (\%) das amostras sinterizadas preparadas pelo método de mistura de óxidos para as rotas utilizadas.

\begin{tabular}{|c|c|c|c|c|c|}
\hline $\begin{array}{c}\text { Condições } \\
\left({ }^{\circ} \mathrm{C} / \mathrm{h}\right)\end{array}$ & $\begin{array}{c}\text { Densidade } \\
(\%) \\
\mathrm{C}-1000^{\circ} \mathrm{C}\end{array}$ & $\begin{array}{c}\text { Densidade } \\
(\%) \\
\mathrm{C}-1250^{\circ} \mathrm{C}\end{array}$ & $\begin{array}{c}\text { Densidade } \\
(\%) \\
\mathrm{C}-1350^{\circ} \mathrm{C}\end{array}$ & $\begin{array}{c}\text { Densidade } \\
(\%) \\
\mathrm{M}-1350^{\circ} \mathrm{C}\end{array}$ & $\begin{array}{c}\text { Densidade } \\
(\%) \\
\text { M2-1350 }\end{array}$ \\
\hline $1300 / 2$ & ---- & $87 \pm 1$ & --- & ---- & ---- \\
\hline $1350 / 2$ & ---- & $92 \pm 1$ & --- & ---- & ---- \\
\hline $1400 / 2$ & ---- & $97 \pm 1$ & $89 \pm 1$ & --- & --- \\
\hline $1430 / 2$ & $98 \pm 1$ & --. & $96 \pm 1$ & $97 \pm 1$ & $96 \pm 1$ \\
\hline $1450 / 1$ & $98 \pm 1$ & $99 \pm 1$ & $95 \pm 1$ & $96 \pm 1$ & $97 \pm 1$ \\
\hline $1450 / 2$ & $97 \pm 1$ & $99 \pm 1$ & $95 \pm 1$ & $95 \pm 1$ & $95 \pm 1$ \\
\hline $1450 / 4$ & $99 \pm 1$ & $99 \pm 1$ & $97 \pm 1$ & $97 \pm 1$ & $98 \pm 1$ \\
\hline $1480 / 1$ & $98 \pm 1$ & --- & $91 \pm 1$ & $97 \pm 1$ & $98 \pm 1$ \\
\hline $1480 / 2$ & $99 \pm 1$ & --- & $97 \pm 1$ & $97 \pm 1$ & $97 \pm 1$ \\
\hline $1500 / 2$ & $98 \pm 1$ & $98 \pm 1$ & $92 \pm 1$ & $96 \pm 1$ & $97 \pm 1$ \\
\hline $1500 / 6$ & -- & $99 \pm 1$ & - & -- & $99 \pm 1$ \\
\hline
\end{tabular}

As amostras preparadas com calcinações sucessivas a $1250{ }^{\circ} \mathrm{C}$ apresentam maiores densidades do que aquelas obtidas para as outras rotas nas mesmas condições de sinterização. Para todas as rotas variando a temperatura ocorre uma variação na densidade que pode estar relacionada com as fases secundárias que possuem densidades e simetrias variadas, Tabela III.

As densidades obtidas neste trabalho são superiores a valores de densidade reportados na literatura para as mesmas condições de sinterização para amostras preparadas pelo método de mistura de óxidos, [22, 45], ou seja, as moagens em moinho tipo atritor foram efetivas para obter valores de densidades mais elevados.

A Tabela VIII lista as densidades das amostras obtidas pelo método do complexação de cátions variando a temperatura de sinterização, com tempo de patamar fixo de $4 \mathrm{~h}$ e variando o tempo de patamar para a temperatura fixa de $1400 \stackrel{\circ}{\circ}$. 
Tabela VIII - Densidade relativa (\%) das amostras sinterizadas preparadas pelo método de complexação de cátions variando a temperatura com o tempo de patamar fixo de $4 \mathrm{~h}$ e com a temperatura de patamar fixa $1400{ }^{\circ} \mathrm{C}$, variando $\mathrm{o}$ tempo de patamar.

\begin{tabular}{cccc}
\hline \hline $\begin{array}{c}\text { Condições } \\
\left({ }^{\circ} \mathbf{C} / \mathbf{h}\right)\end{array}$ & $\begin{array}{c}\text { Densidade } \\
(\%)\end{array}$ & $\begin{array}{c}\text { Condições } \\
\left({ }^{\circ} \mathbf{C} / \mathbf{h}\right)\end{array}$ & $\begin{array}{c}\text { Densidade } \\
(\% \text { DT) }\end{array}$ \\
\hline $1300 / 4$ & $92 \pm 1$ & $1400 / 4$ & $93 \pm 1$ \\
$1350 / 4$ & $92 \pm 1$ & $1400 / 10$ & $95 \pm 1$ \\
$1400 / 4$ & $93 \pm 1$ & $1400 / 15$ & $96 \pm 1$ \\
$1450 / 4$ & $94 \pm 1$ & & \\
$1500 / 4$ & $95 \pm 1$ & & \\
\hline \hline
\end{tabular}

As amostras obtidas pelo método de complexação de cátions apresentam densidades relativas superiores a $92 \%$, mas inferiores à das amostras preparadas por mistura de óxidos e sinterizadas sob as mesmas condições. Quando sinterizada a $1450{ }^{\circ} \mathrm{C} / 4 \mathrm{~h}$ apresenta densidade de $94 \%$. Tempos longos de patamar e temperaturas elevadas aumentam o valor da densidade.

Os valores de densidade obtidos para as amostras preparadas pelo método de complexação são similares às amostras preparadas por sol-gel [53] e inferior às amostras preparadas por liofilização [85] e etileno glicol [87] para as mesmas condições de sinterização e composição. Poucos são os trabalhos em que a densidade do LSGM é reportada quando são utilizados métodos químicos de síntese.

\section{Microscopia Eletrônica de Varredura}

Foram realizadas observações no microscópio eletrônico de varredura para as amostras obtidas pelo método de mistura de óxidos e pelo método de complexação de cátions.

A Figura 35 mostra micrografias obtidas para as diferentes rotas preparadas pelo método de mistura de óxidos sinterizadas a $1450{ }^{\circ} \mathrm{C} / 4 \mathrm{~h}$. 

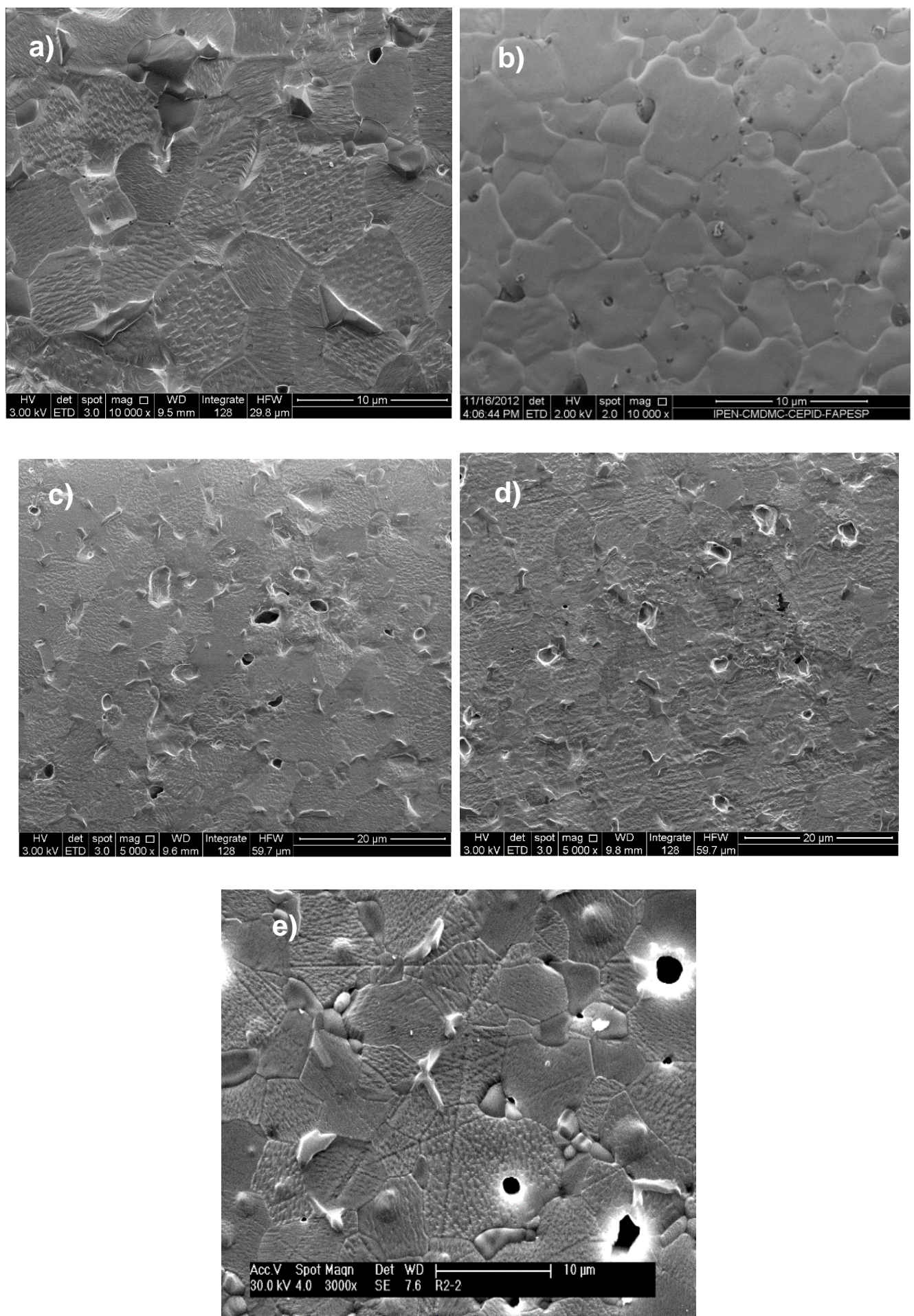

Figura 35: Micrografias obtidas em microscópio eletrônico de varredura de amostras sinterizadas a $1450^{\circ} \mathrm{C} / 4 \mathrm{~h}$ obtidas pelo método de mistura de óxidos para as diferentes rotas com calcinações sucessivas a a) $1000^{\circ} \mathrm{C}$, b) $1250{ }^{\circ} \mathrm{C}$ c) $1350{ }^{\circ} \mathrm{C}$ e d) uma calcinação a $1350^{\circ} \mathrm{C}$ com moagens intercaladas, e) duas calcinações a $1350^{\circ} \mathrm{C}$ com moagens intercaladas.

A microestrutura é bastante heterogênea como pode ser observado nas micrografias. Observa-se que as amostras consistem de grãos grandes e 
pequenos, alguns com aspecto rugoso e outros liso. Grãos pequenos estão principalmente nas regiões dos contornos de grãos.

Os grãos com aparência lisa e os grãos com aparência rugosa apresentam a mesma composição, verificado por EDS. Resultado similar foi encontrado por $\mathrm{X}$. Zhao que afirmaram que essa diferença pode estar associada ao resfriamento [25]. Entretanto, Y-Chuan Wu e colaboradores atribuíram essa rugosidade a uma falha de empilhamento [47]. I. Stijepovic atribuiu essa rugosidade ao ataque térmico realizado nas amostras.

A Figura 36 mostra as micrografias obtidas para as amostras preparadas por mistura de óxidos com calcinações sucessivas a $1250{ }^{\circ} \mathrm{C}$ e sinterizadas na temperatura de $1450 \stackrel{\circ}{\circ}$ variando o tempo de patamar.
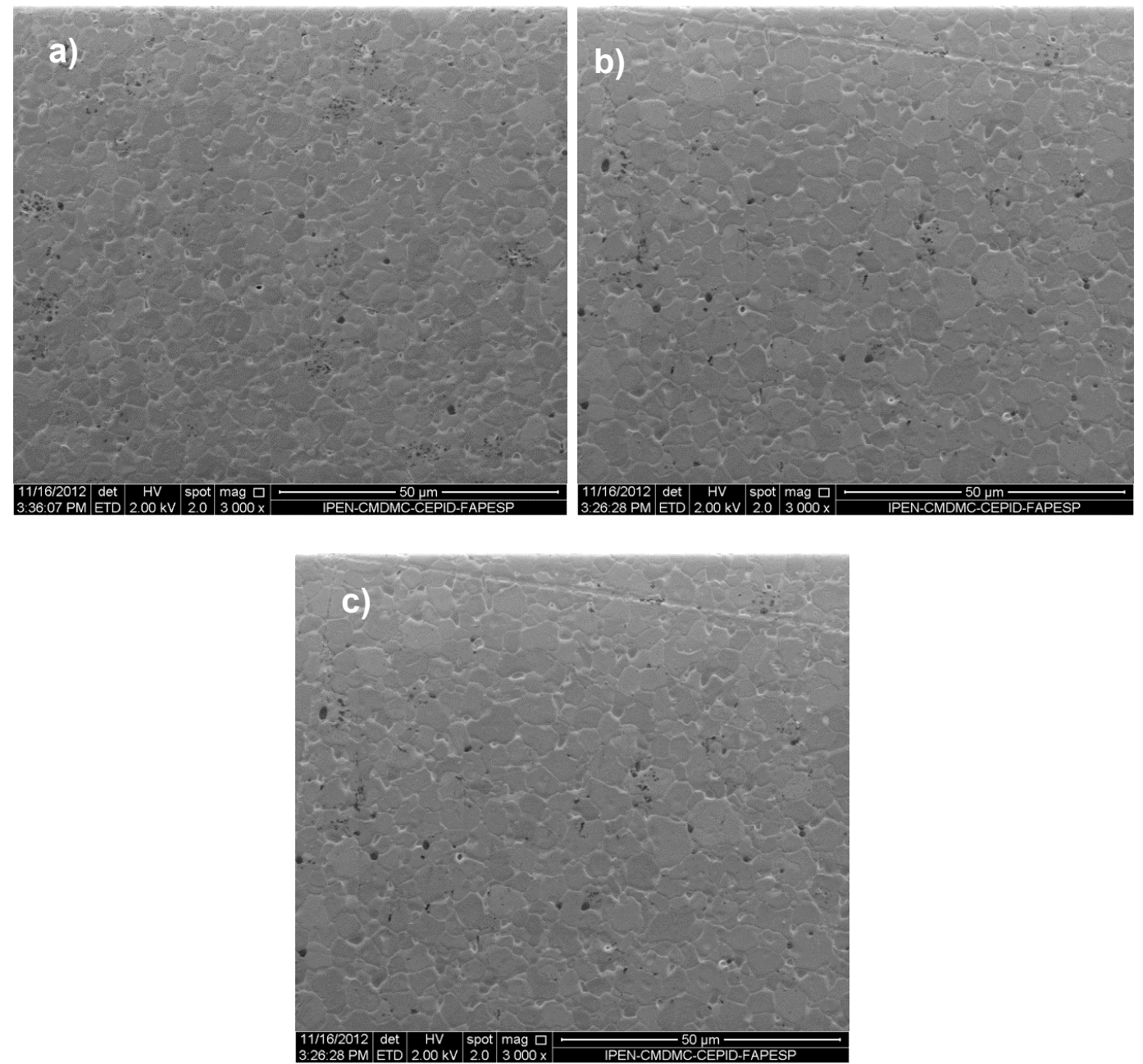

Figura 36: Micrografias obtidas em microscópio eletrônico de varredura de amostras obtidas pelo método de mistura de óxidos com calcinações sucessivas a $1250{ }^{\circ} \mathrm{C}$ e sinterizadas a) $1450{ }^{\circ} \mathrm{C} / 1 \mathrm{~h}$, b) $1450{ }^{\circ} \mathrm{C} / 2 \mathrm{~h}$ e c) $1450^{\circ} \mathrm{C} / 4 \mathrm{~h}$. 
O aumento do tempo favorece o aumento no tamanho médio de grãos das amostras e não ocorre modificação na morfologia, como esperado.

A Figura 37 mostra micrografias obtidas para as amostras sinterizadas em diferentes temperaturas com tempo de patamar fixo de $2 \mathrm{~h}$ com calcinações sucessivas a $1250^{\circ} \mathrm{C}$.
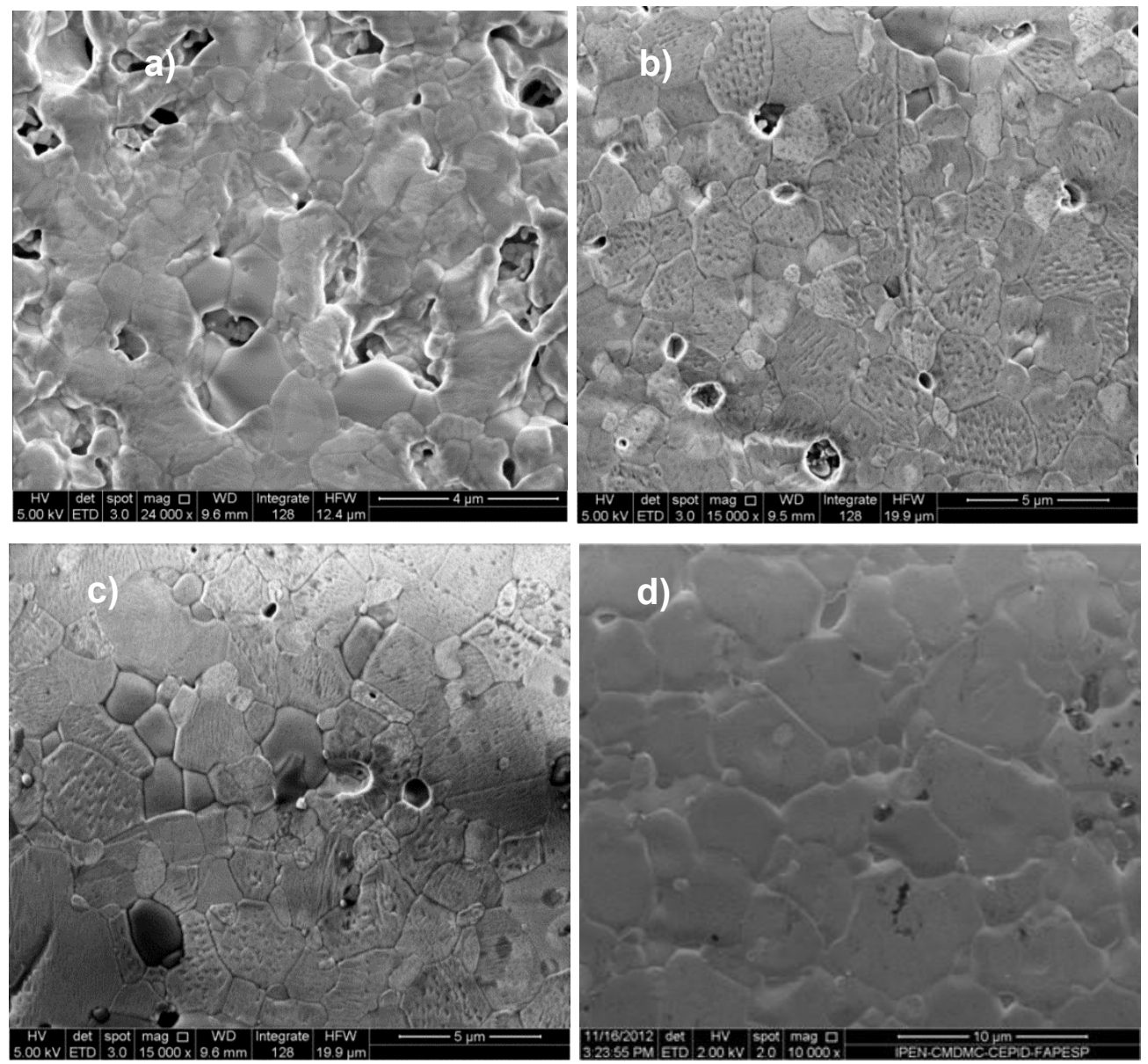

Figura 37: Micrografias obtidas em microscópio eletrônico de varredura de amostras obtidas pelo método de mistura de óxidos com calcinações sucessivas a $12500^{\circ} \mathrm{C}$ e sinterizadas com tempo de patamar fixo de $2 \mathrm{~h}$ a) $1300^{\circ} \mathrm{C}$, b) $\left.1350^{\circ} \mathrm{C}, \mathrm{c}\right) 1400^{\circ} \mathrm{C}$ e d) $1450^{\circ} \mathrm{C}$.

As amostras consistem de grãos não homogêneos com relação a tamanho e morfologia. Notam-se grãos micrométricos e existe porosidade que diminui com o aumento da temperatura de patamar.

De modo geral, as amostras com calcinações sucessivas a $1250{ }^{\circ} \mathrm{C}$ apresentam maior homogeneidade microestrutural relativamente às demais rotas utilizadas. 
A Figura 38 mostra as micrografias obtidas para as amostras preparadas por mistura de óxidos com duas calcinações a $1350{ }^{\circ} \mathrm{C}$ com moagens intercaladas, e sinterizadas na temperatura de $1450{ }^{\circ} \mathrm{C}$ variando o tempo de patamar.
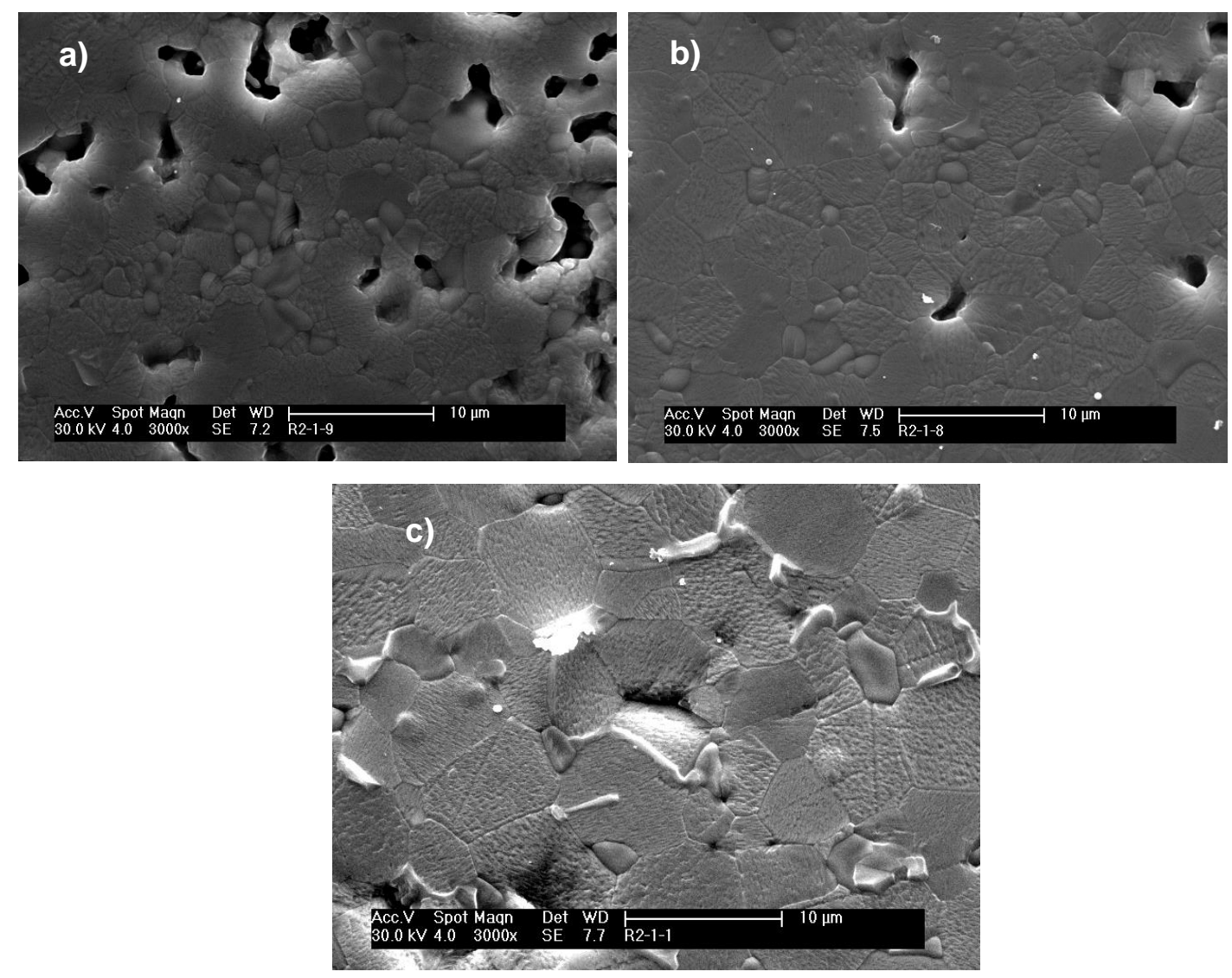

Figura 38: Micrografias obtidas em microscópio eletrônico de varredura de amostras sinterizadas e obtidas pelo método de mistura de óxidos calcinadas a $1350{ }^{\circ} \mathrm{C}$ com moagens intercaladas a) $1450{ }^{\circ} \mathrm{C} / 1 \mathrm{~h}$, b) $1450{ }^{\circ} \mathrm{C} / 2 \mathrm{~h} \mathrm{e}$ c) $1450^{\circ} \mathrm{C} / 4 \mathrm{~h}$.

As amostras com duas calcinações a $1350{ }^{\circ} \mathrm{C}$ e moagens intercaladas consistem de grãos não homogêneos com relação ao tamanho e morfologia. Grãos menores principalmente na região dos contornos de grãos. Notam-se grãos micrométricos e existe porosidade que diminui com o aumento do tempo de patamar.

A Figura 39 mostra micrografias obtidas para as amostras preparadas pelo método de mistura de óxidos, com calcinações sucessivas a $1250{ }^{\circ} \mathrm{C}$ e amostras preparadas com duas calcinações a $1350{ }^{\circ} \mathrm{C}$ com moagens intercaladas e sinterizadas a $1500^{\circ} \mathrm{C} / 6 \mathrm{~h}$. 

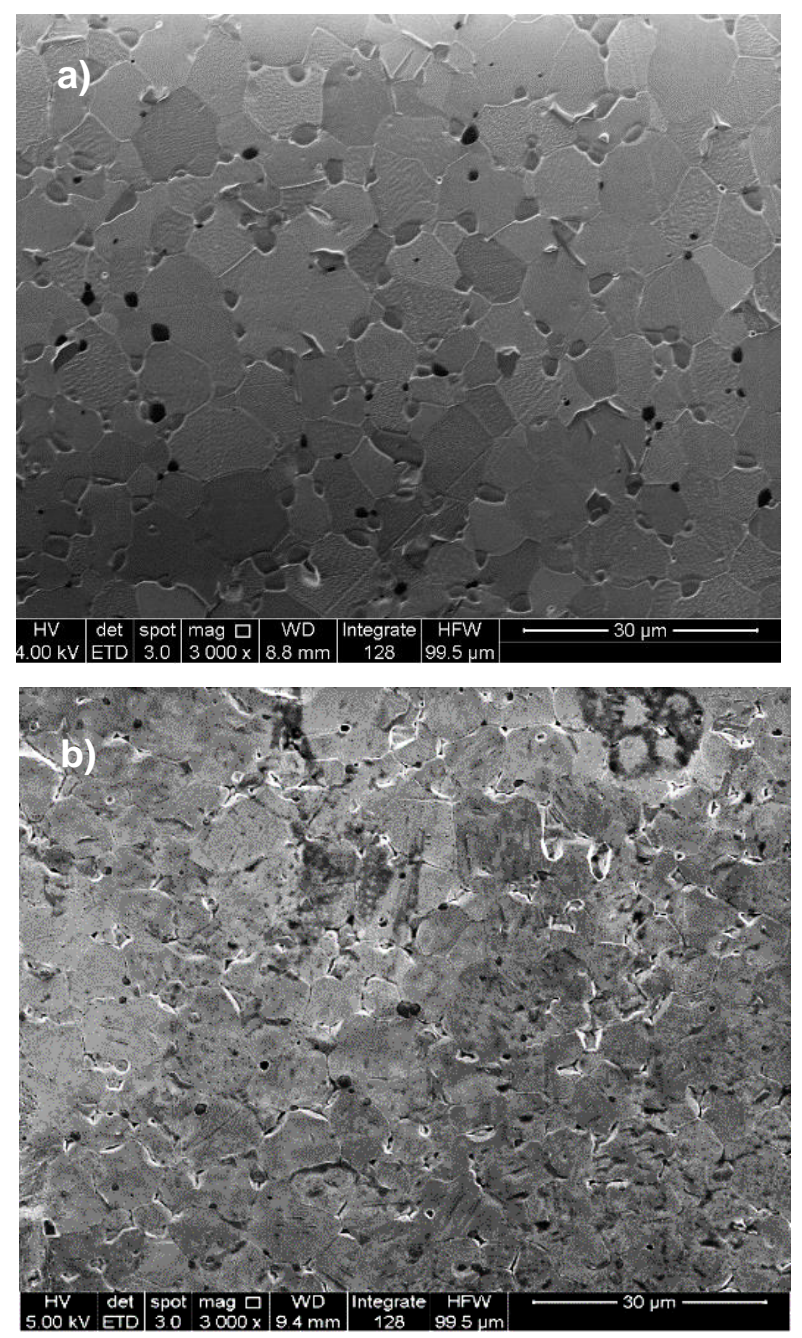

Figura 39: Micrografias obtidas em microscópio eletrônico de varredura de amostras sinterizadas a $1500^{\circ} \mathrm{C} / 6 \mathrm{~h}$ obtidas pelo método de mistura de óxidos a) calcinações sucessivas a $1250{ }^{\circ} \mathrm{C}$ b) com duas calcinações a $1350{ }^{\circ} \mathrm{C} \mathrm{com}$ moagens intercaladas.

O aumento do tempo e temperatura para as duas rotas promoveram 0 aumento das fases secundárias e do tamanho médio de grão.

A Figura 40 mostra micrografias obtidas para as amostras preparadas pelo método de complexação de cátions, com tempo de patamar fixo de $4 \mathrm{~h}$ variando a temperatura de sinterização. 

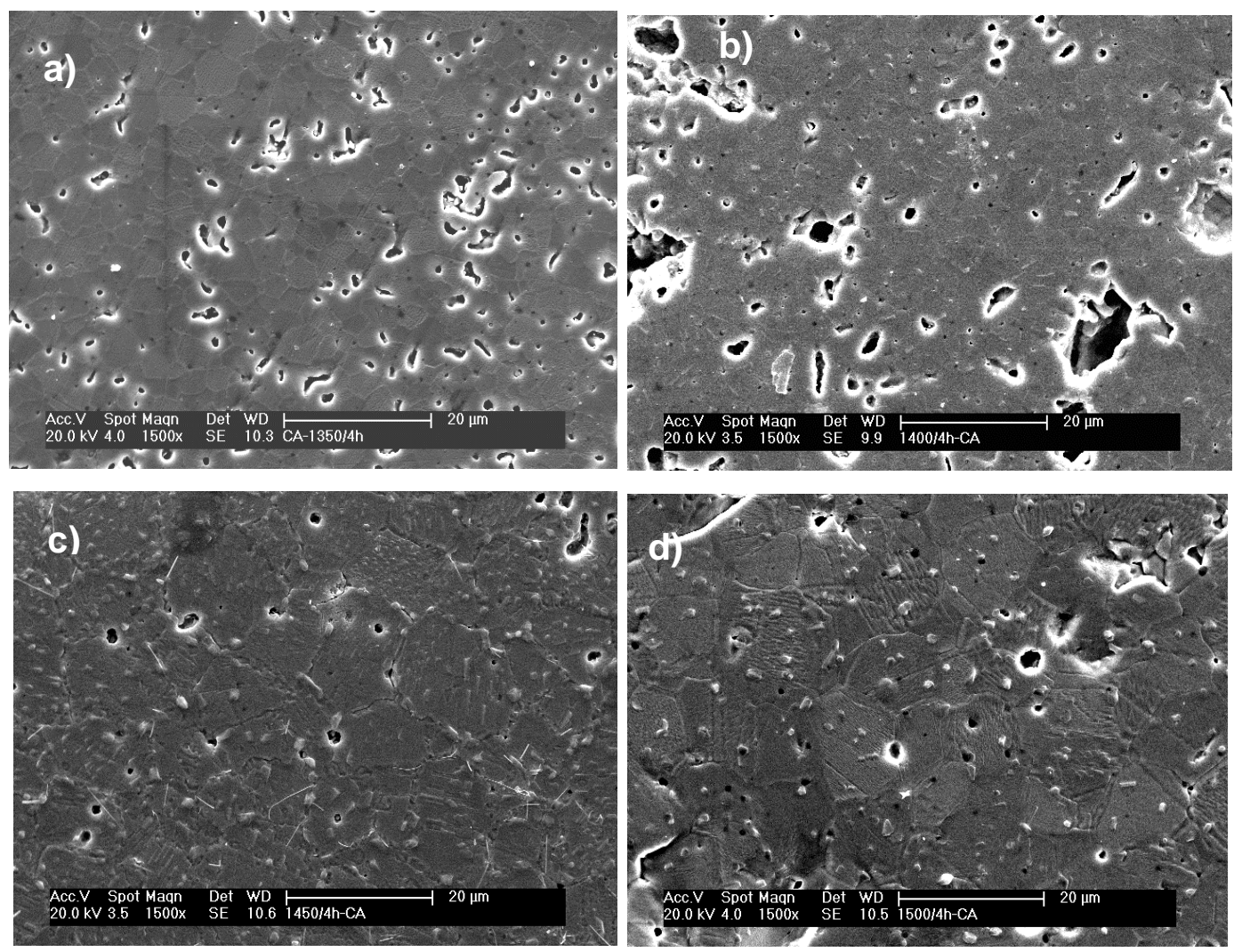

Figura 40: Micrografias obtidas em microscópio eletrônico de varredura de amostras sinterizadas obtidas pelo método de complexação de cátions com tempo fixo de $4 \mathrm{~h}$ variando a temperatura de patamar: a) $1350{ }^{\circ} \mathrm{C}$, b) $1400{ }^{\circ} \mathrm{C}$, c) $\left.1450^{\circ} \mathrm{C}, \mathrm{d}\right) 1500^{\circ} \mathrm{C}$.

As amostras preparadas pelo método de complexação de cátions, sinterizadas a $1350,1400,1450$ e $1500{ }^{\circ} \mathrm{C}$ durante $4 \mathrm{~h}$ apresentaram grãos micrométricos e homogeneidade com relação ao tamanho e morfologia. $\mathrm{O}$ aumento da temperatura de sinterização promoveu o crescimento dos grãos e a diminuição gradual da porosidade. Os pontos escuros observados nas amostras, Figura 40, estão associados à presença de grãos de $\mathrm{MgO}$, confirmado por EDS. Outros autores também observaram a presença de MgO $[67,83]$.

A Figura 41 mostra micrografias obtidas para as amostras preparadas pelo método de complexação de cátions, com temperatura fixa de $1400{ }^{\circ} \mathrm{C}$ variando o tempo de patamar. 

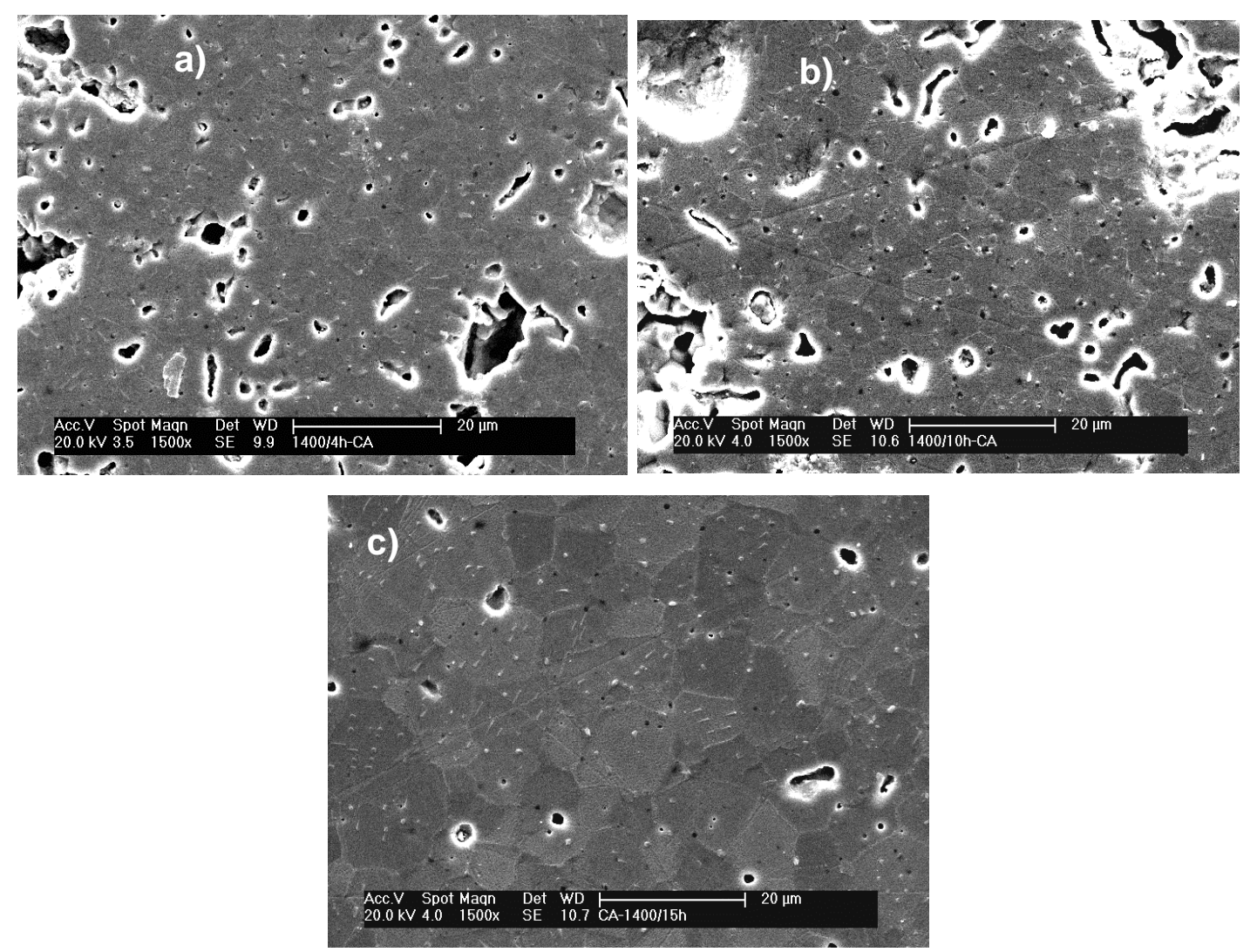

Figura 41: Micrografias obtidas em microscópio eletrônico de varredura de amostras sinterizadas obtidas pelo método de complexação de cátions com temperatura fixa de $1400{ }^{\circ} \mathrm{C}$ variando o tempo de patamar. a) $4 \mathrm{~h}$, b) $10 \mathrm{~h}$ e c) $15 \mathrm{~h}$.

Neste caso, àquelas sinterizadas com tempo de patamar fixo e variando a temperatura apresentam características semelhantes às amostras com tempo de patamar fixo variando a temperatura de sinterização. O aumento do tempo de sinterização favorece o crescimento dos grãos, eliminação da porosidade e a formação de grãos de $\mathrm{MgO}$.

Precipitados de óxido de magnésio foram observados nas amostras preparadas pelos dois métodos de síntese.

As amostras preparadas pelo método de complexação apresentam tamanho e aspecto mais homogêneos comparados com as amostras obtidas pelo método de mistura de óxidos.

Nas Tabelas IX e X são listados os valores de tamanho médio de grãos determinados pelo método de Mendelson [112] para as amostras preparadas pelo método de mistura de óxidos e pelo método de complexação, 
respectivamente, em diversas condições de sinterização. DV é o desvio padrão e mede a dispersão no tamanho médio de grãos.

Tabela IX - Tamanho médio de grãos para as amostras preparadas por mistura de óxidos, sinterizadas em diversas condições.

\begin{tabular}{cccc}
\hline Rota & $\begin{array}{c}\text { Condições de } \\
\text { sinterização }\left({ }^{\circ} \mathbf{C} / \mathbf{h}\right)\end{array}$ & $\begin{array}{c}\text { Tamanho médio } \\
\text { de grão }(\boldsymbol{\mu m})\end{array}$ & $\begin{array}{c}\text { Desvio padrão } \\
(\mathbf{D V})\end{array}$ \\
\hline C-1000 & $1450 / 1$ & $5,47 \pm 0,11$ & 1,72 \\
C-1000 & $1450 / 4$ & $9,94 \pm 0,18$ & 2,96 \\
C-1250 & $1300 / 2$ & $1,64 \pm 0,04$ & 0,73 \\
C-1250 & $1350 / 2$ & $2,88 \pm 0,07$ & 1,24 \\
C-1250 & $1400 / 2$ & $3,45 \pm 0,09$ & 1,46 \\
C-1250 & $1450 / 1$ & $5,31 \pm 0,15$ & 2,20 \\
C-1250 & $1450 / 2$ & $6,80 \pm 0,20$ & 2,90 \\
C-1250 & $1450 / 4$ & $7,49 \pm 0,20$ & 3,28 \\
C-1250 & $1500 / 6$ & $13,28 \pm 0,26$ & 4,22 \\
C-1350 & $1450 / 1$ & $5,01 \pm 0,12$ & 1,96 \\
C-1350 & $1450 / 4$ & $10,15 \pm 0,18$ & 2,87 \\
M-1350 & $1450 / 1$ & $5,45 \pm 0,10$ & 1,71 \\
M-1350 & $1450 / 4$ & $9,66 \pm 0,19$ & 2,46 \\
M2-1350 & $1450 / 1$ & $4,82 \pm 0,10$ & 1,68 \\
M2-1350 & $1450 / 2$ & $5,45 \pm 0,12$ & 1,97 \\
M2-1350 & $1450 / 4$ & $8,00 \pm 0,18$ & 2,99 \\
M2-1350 & $1500 / 2$ & $7,99 \pm 0,20$ & 3,18 \\
M2-1350 & $1500 / 6$ & $11,45 \pm 0,24$ & 3,90 \\
\hline \hline
\end{tabular}

O aumento da temperatura e tempo de patamar favoreceu o aumento do tamanho médio de grãos para todas as amostras preparadas pelo método de mistura de óxido. Amostras preparadas com calcinações sucessivas a $1250{ }^{\circ} \mathrm{C}$ apresentam menor tamanho médio de grão quando sinterizadas a $1450{ }^{\circ} \mathrm{C} / 4 \mathrm{~h}$ comparado às demais rotas.

Tabela X - Tamanho médio de grãos para as amostras preparadas pelo método de complexação de cátions, sinterizadas em diversas condições.

\begin{tabular}{cccc}
\hline \hline Rota & $\begin{array}{c}\text { Condiçães de } \\
\text { sinterização } \\
\left({ }^{\circ} \mathbf{C} / \mathbf{h}\right)\end{array}$ & $\begin{array}{c}\text { Tamanho médio } \\
\text { de grão }(\boldsymbol{\mu m})\end{array}$ & $\begin{array}{c}\text { Desvio padrão } \\
(\mathbf{D V})\end{array}$ \\
\hline Complexação de cátions & $1350 / 4$ & $5,15 \pm 0,10$ & 1,68 \\
Complexação de cátions & $1400 / 4$ & $5,69 \pm 0,11$ & 1,70 \\
Complexação de cátions & $1400 / 10$ & $8,80 \pm 0,28$ & 4,56 \\
Complexação de cátions & $1400 / 15$ & $12,06 \pm 0,26$ & 4,13 \\
Complexação de cátions & $1450 / 4$ & $14,04 \pm 0,32$ & 4,88 \\
Complexação de cátions & $1500 / 4$ & $15,01 \pm 0,41$ & 5,82 \\
\hline \hline
\end{tabular}

Amostras preparadas pelo método de complexação de cátions apresentaram tamanho médio de grãos maiores do que aquelas preparadas 
por mistura de óxidos nas mesmas condições de sinterização. Isto indica que o crescimento de grãos é acelerado quando nanopartículas desta composição são utilizadas na elaboração de amostras.

\section{Microanálise de energia dispersiva (EDS)}

De modo a confirmar os resultados obtidos por DRX com relação às fases secundárias, e observação em microscópio eletrônico de varredura, que mostrou regiões com diferentes características, foram selecionadas as seguintes amostras para serem investigadas por EDS: a) aquelas com calcinações sucessivas a $1250{ }^{\circ} \mathrm{C}$, b) com duas calcinações a $1350{ }^{\circ} \mathrm{C}$ com moagens intercaladas e c) as amostras preparadas pelo método de complexação, as condições de sinterização foram $1450{ }^{\circ} \mathrm{C} / 4 \mathrm{~h}$ e $1500{ }^{\circ} \mathrm{C} / 6 \mathrm{~h}$.

A Figura 42 mostra a distribuição dos elementos ( $\mathrm{La}, \mathrm{Sr}, \mathrm{Ga}$ e Mg), obtidos por EDS, para amostras preparadas por mistura de óxidos com calcinações sucessivas a $1250{ }^{\circ} \mathrm{C}$ e sinterizadas a $1450{ }^{\circ} \mathrm{C} / 4 \mathrm{~h}$. As cores atribuídas aos elementos La, Sr, Ga e Mg são, respectivamente, roxo, verde, azul e vermelho.

A partir da análise por mapeamento, pode-se perceber que pontos escuros observados na micrografia da Figura 42a apresentam concentração elementar diferente da matriz, região cinza (Figura 42a) constituída por LSGM. Além disso, diferentes concentrações de elementos foram identificadas nos pontos escuros. Dessa forma, pontos arredondados, de cor vermelha (Figura 42b), são atribuídos a precipitados de MgO. Resultado similar foi obtido por outros autores para o LSGM preparado pelo método de mistura de óxidos [25]. 

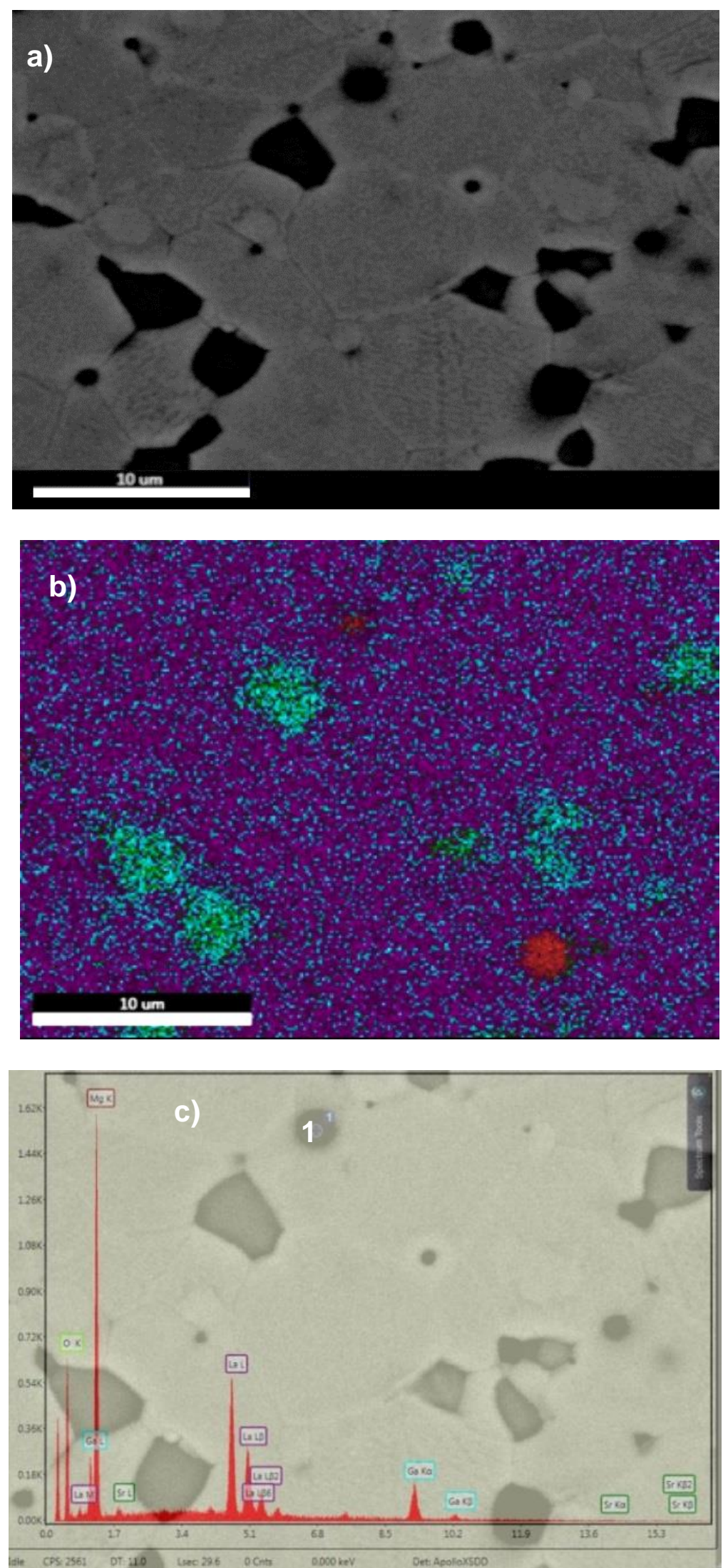

Figura 42: a) micrografia obtida por elétrons retroespalhados, b) mapeamento dos elementos por EDS, c) espectro dos elementos da região 1, de amostras com calcinações sucessivas a $1250{ }^{\circ} \mathrm{C}$ e sinterizadas a $1450{ }^{\circ} \mathrm{C} / 4 \mathrm{~h}$. (Vermelho-Mg; verde-Sr; azul-Gálio e roxo-La). 

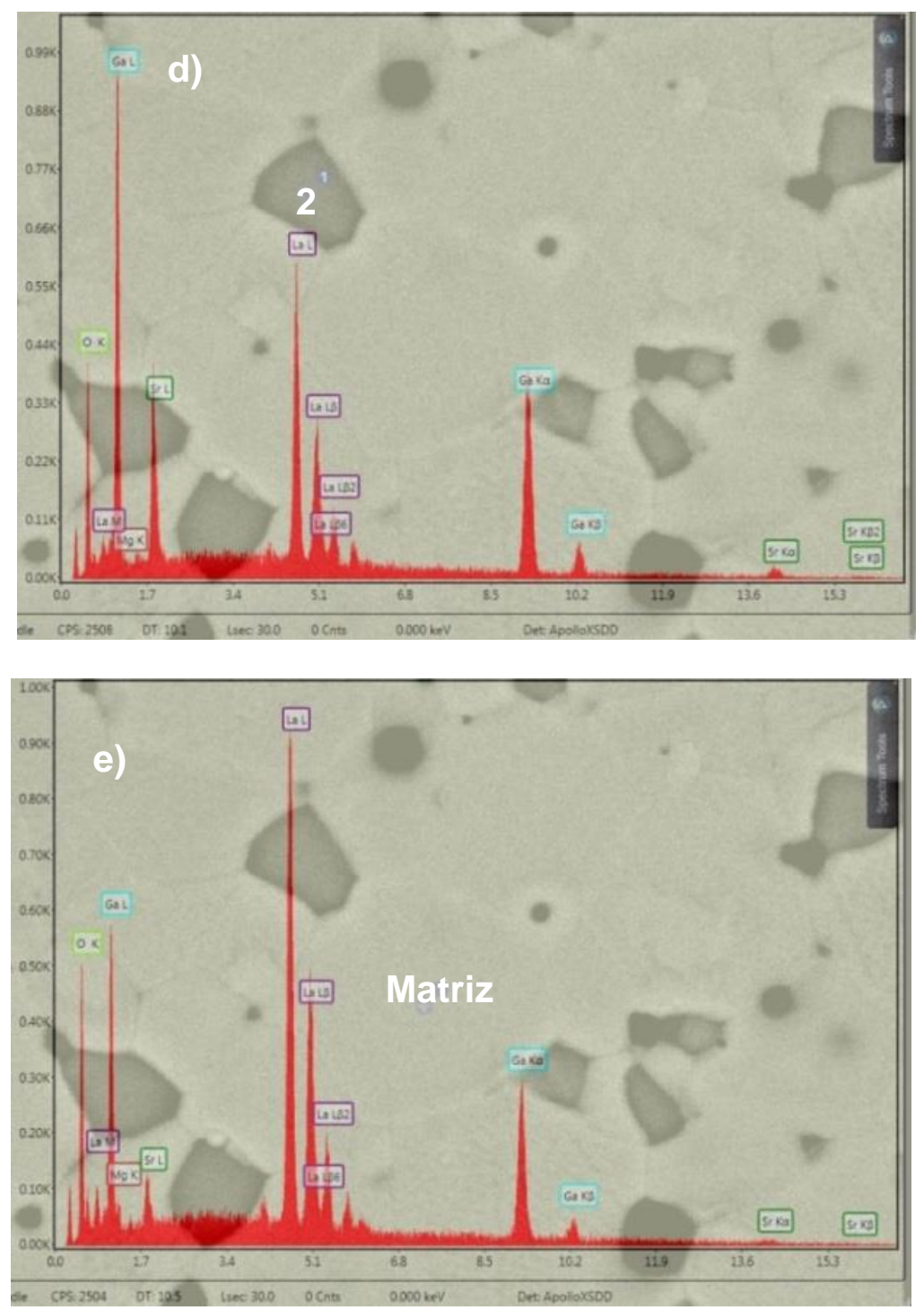

Figura 42: (cont.) d) espectro dos elementos da região 2, e) espectro dos elementos da matriz, de amostras com calcinações sucessivas a $1250{ }^{\circ} \mathrm{C}$ e sinterizadas a $1450 \stackrel{\circ}{\mathrm{C}} / 4 \mathrm{~h}$. (Vermelho-Mg; verde-Sr; azul-Gálio e roxo-La).

Enquanto que, regiões com predominância de coloração verde e azul ( $\mathrm{Sr}$ e $\mathrm{Ga}$ ) na Figura 42b, indicam que há uma composição de fases secundárias, constituída por: $\mathrm{SrLaGaO}_{4}$ e $\mathrm{LaSrGa}_{3} \mathrm{O}_{7}$, o que está de acordo com os resultados encontrados por difração de raios X, Figura 24.

A região correspondente à matriz do LSGM possui uma uniformidade entre o roxo e o azul que estão associados ao La e $\mathrm{Ga}$, respectivamente. Foi realizado um mapeamento pontual da amostra em três regiões, Figura 42c-e. 
A precipitação de $\mathrm{MgO}$ tem sido reportado para o LSGM preparado pelo método de mistura de óxidos [25]. Embora o óxido de magnésio não tenha sido detectado por difração de raios $\mathrm{X}$ em amostras sinterizadas, a análise de mapeamento por EDS permitiu identificar grãos de MgO, Figura 42c.

$\mathrm{O}$ resultado obtido com o mapeamento da matriz, Figura 42e, mostra que ocorre uma perda de gálio, a qual está associada com à formação da fase secundária $\mathrm{SrLaGa}_{3} \mathrm{O}_{7}$ rica em gálio, confirmada pela Figura $42 \mathrm{~d}$ e por difração de raios X, Figura 24. Esse resultado está de acordo com o observado por A. Moure [13].

As Figuras 43 e 44 mostram a distribuição dos elementos (La, $\mathrm{Sr}, \mathrm{Ga}$ e $\mathrm{Mg}$ ), obtidos por EDS, para amostras preparadas por mistura de óxidos com calcinações sucessivas a $1250^{\circ} \mathrm{C}$ e amostras com duas calcinações a $1350^{\circ} \mathrm{C}$ com moagens intercaladas e sinterizadas a $1500^{\circ} \mathrm{C} / 6 \mathrm{~h}$, respectivamente.

A microestrutura é bastante heterogênea como pode ser observado na micrografia. As amostras consistem de grãos de diferentes tamanhos, alguns com aspecto rugoso e outros liso.

A partir da análise por mapeamento, é possível perceber que pontos escuros observados na micrografia da Figura 43a apresentam concentração elementar diferente da matriz. Os resultados encontrados para as amostras sinterizadas a $1500^{\circ} \mathrm{C} / 6 \mathrm{~h}$ são similares aos obtidos nas amostras sinterizadas a $1450{ }^{\circ} \mathrm{C} / 4 \mathrm{~h}$, ou seja, o aumento da temperatura e tempo não modificou significativamente a distribuição dos elementos na matriz, entretanto é possível observar uma maior distribuição de regiões correspondentes ao $\mathrm{MgO}$ e à fase secundária $\mathrm{SrLaGa}_{3} \mathrm{O}_{7}$ rica em gálio, Figura 43c-e, o que está de acordo com os resultados encontrados por difração de raios X, Figura 31. 

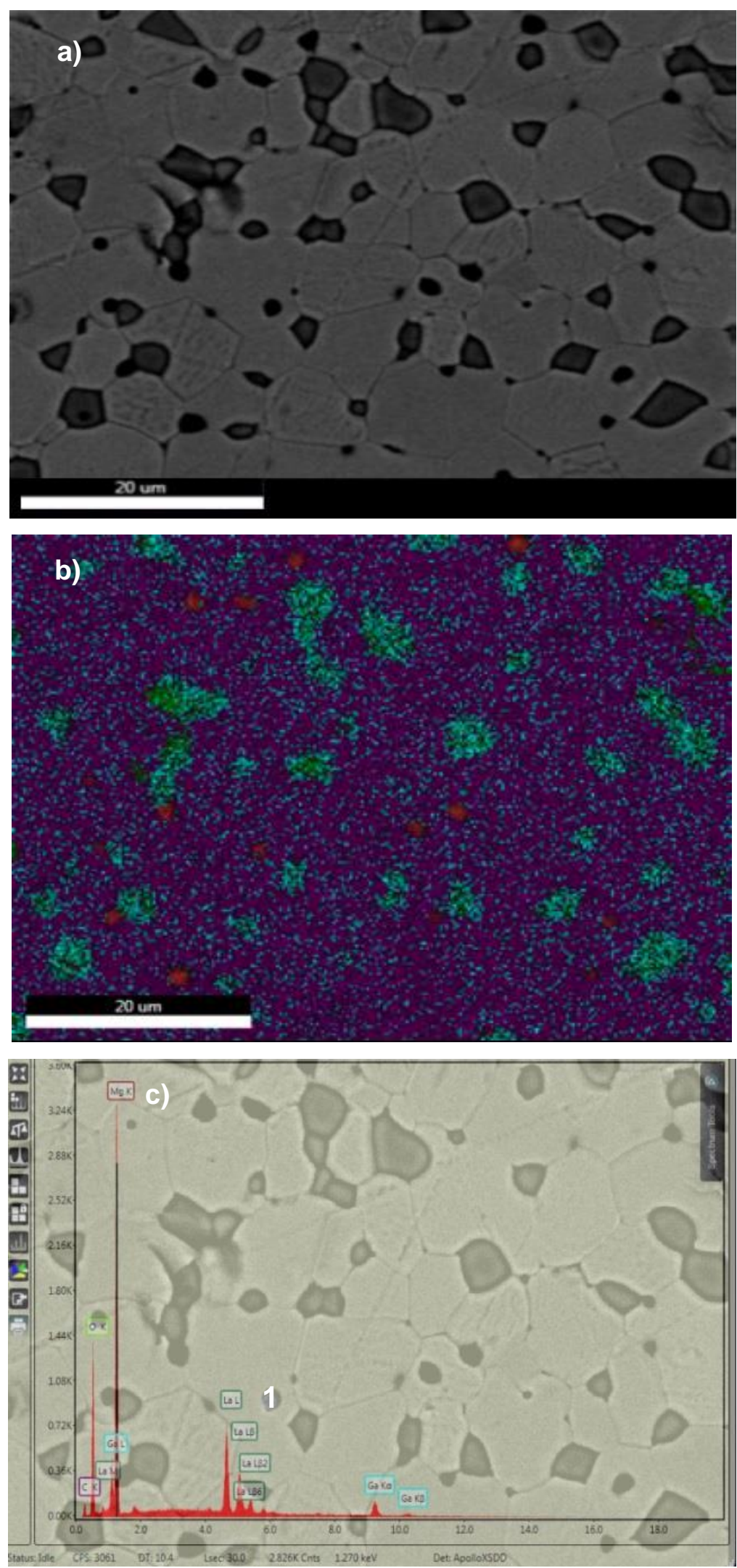

Figura 43: a) micrografia obtida por elétrons retroespalhados e b) mapeamento dos elementos por EDS, c) espectro dos elementos da região 1, de amostras com calcinações sucessivas a $1250{ }^{\circ} \mathrm{C}$ e sinterizadas a $1500{ }^{\circ} \mathrm{C} / 6 \mathrm{~h}$. (Vermelho-Mg; verde-Sr; azul-Gálio e roxo-La). 

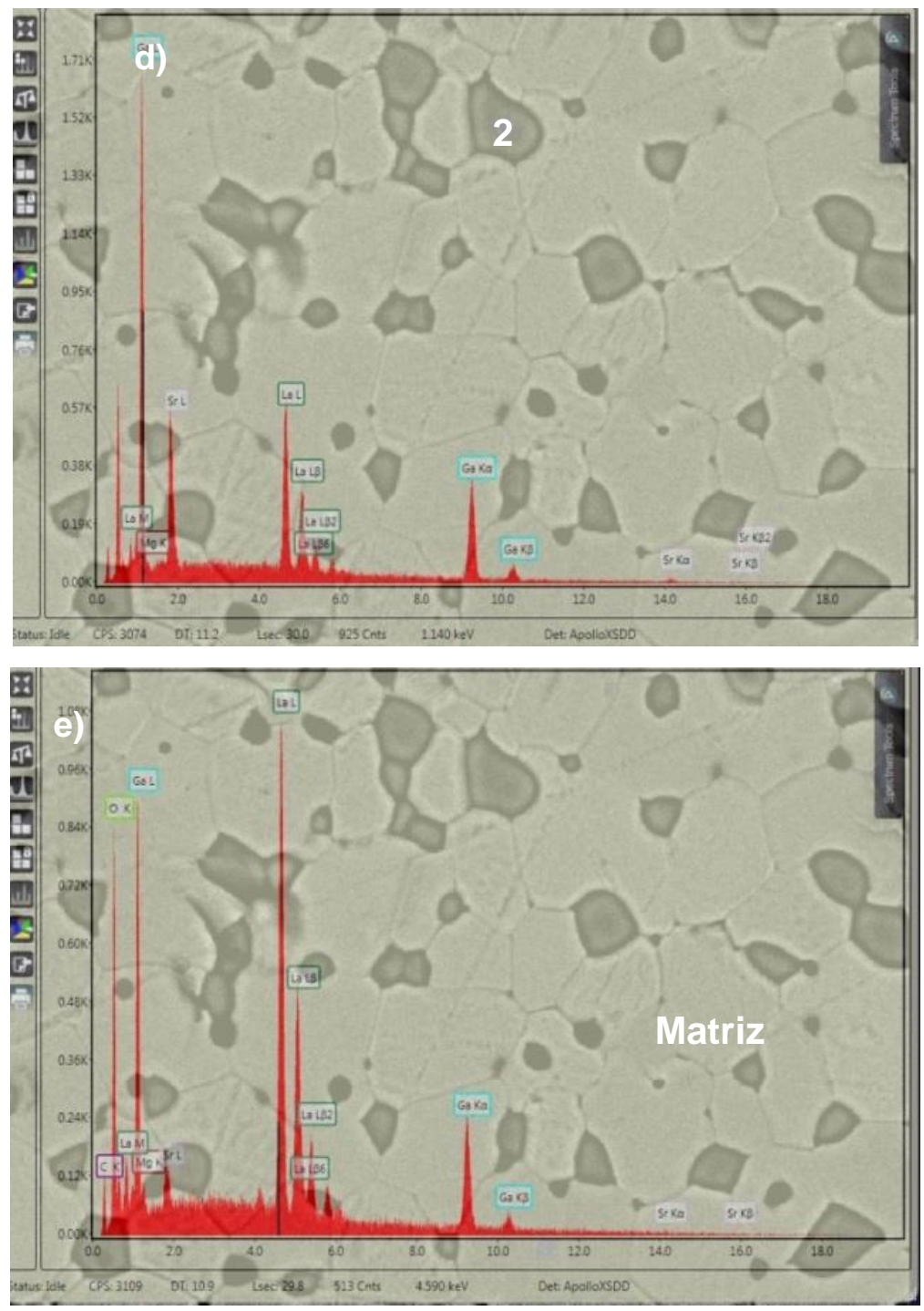

Figura 43: (cont.) d) espectro dos elementos da região 2, e) espectro dos elementos da matriz, de amostras com calcinações sucessivas a $1250{ }^{\circ} \mathrm{C}$ e sinterizadas a $1500^{\circ} \mathrm{C} / 6 \mathrm{~h}$. (Vermelho-Mg; verde-Sr; azul-Gálio e roxo-La). 

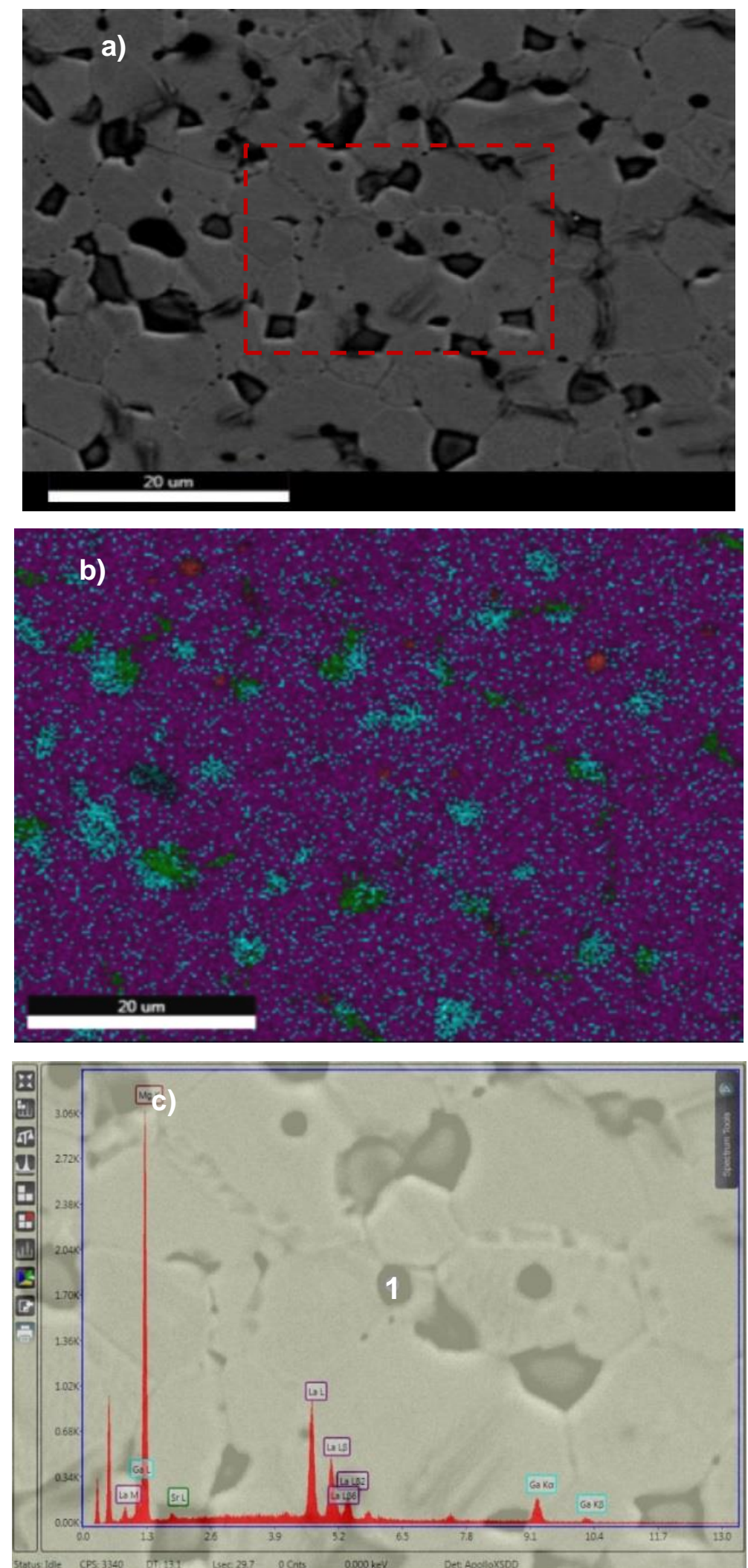

Figura 44: d) espectro dos elementos da região 2, e) espectro dos elementos da matriz, de amostras com duas calcinações a $1350{ }^{\circ} \mathrm{C}$ com moagens intercaladas e sinterizadas a $1500^{\circ} \mathrm{C} / 6 \mathrm{~h}$. (Vermelho-Mg; verde-Sr; azul-Gálio e roxo-La). As regiões c), d), e e) são ampliações da região delimitada na figura $44 a$. 

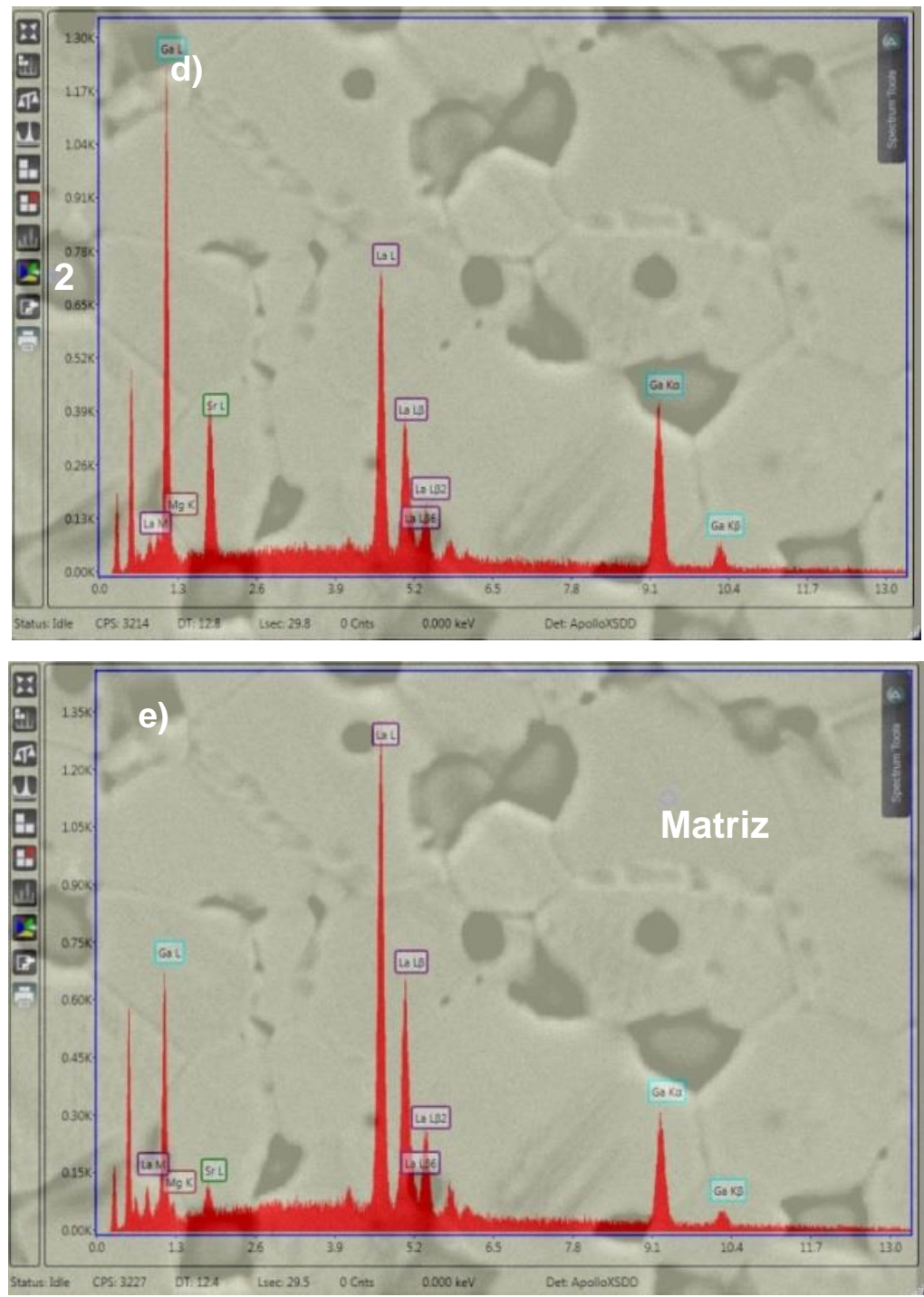

Figura 44: (cont.) d) espectro dos elementos da região 2, e) espectro dos elementos da matriz, de amostras com duas calcinações a $1350{ }^{\circ} \mathrm{C} \mathrm{com}$ moagens intercaladas e sinterizadas a $1500^{\circ} \mathrm{C} / 6 \mathrm{~h}$. (Vermelho-Mg; verde-Sr; azul-Gálio e roxo-La). As regiões c), d), e e) são ampliações da região delimitada na figura 44a.

Os resultados estão de acordo com os obtidos para as amostras com calcinações a $1250{ }^{\circ} \mathrm{C}$ e sinterizadas a $1500{ }^{\circ} \mathrm{C} / 6 \mathrm{~h}$ e confirmam que os pontos arredondados, de cor vermelha (Figura 44b), são atribuídos a precipitados de $\mathrm{MgO}$ e regiões mais escuras, observadas na Figura 44a correspondem a região com predominância de verde e azul na Figura 44b, que estão associados a uma composição de fases secundárias, constituída por: $\mathrm{SrLaGaO}_{4}, \mathrm{La}_{4} \mathrm{Ga}_{2} \mathrm{O}_{9}$ e $\mathrm{SrLaGa}_{3} \mathrm{O}_{7}$ determinadas por difração de raios $\mathrm{X}$, Figura 31. 
As Figuras 44c-e correspondem a uma ampliação da região delimitada na Figura 44a para obter o mapeamento pontual da amostra em três regiões.

A Figura 45 mostra a distribuição dos elementos ( $\mathrm{La}, \mathrm{Sr}, \mathrm{Ga}$ e Mg), obtidos por EDS, para a mostras preparadas pelo método de complexação de cátions e sinterizadas a $1450^{\circ} \mathrm{C} / 4 \mathrm{~h}$.
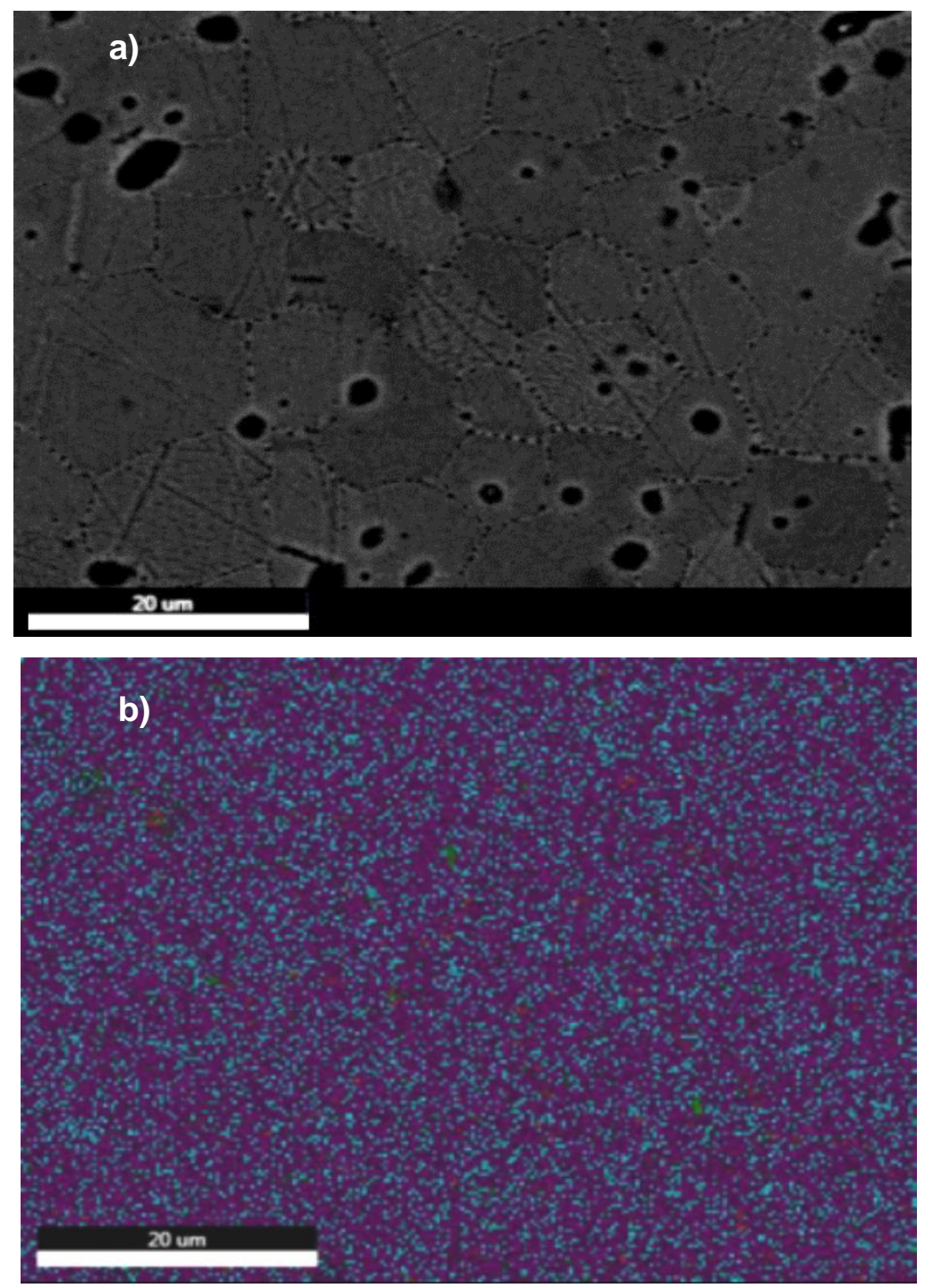

Figura 45: a) Micrografia obtida por elétrons retroespalhados, b) mapeamento dos elementos por EDS, das amostras preparadas pelo método de complexação de cátions sinterizadas a $1450{ }^{\circ} \mathrm{C} / 4 \mathrm{~h}$. (Vermelho-Mg; verde-Sr; azul-Gálio e roxo-La). 

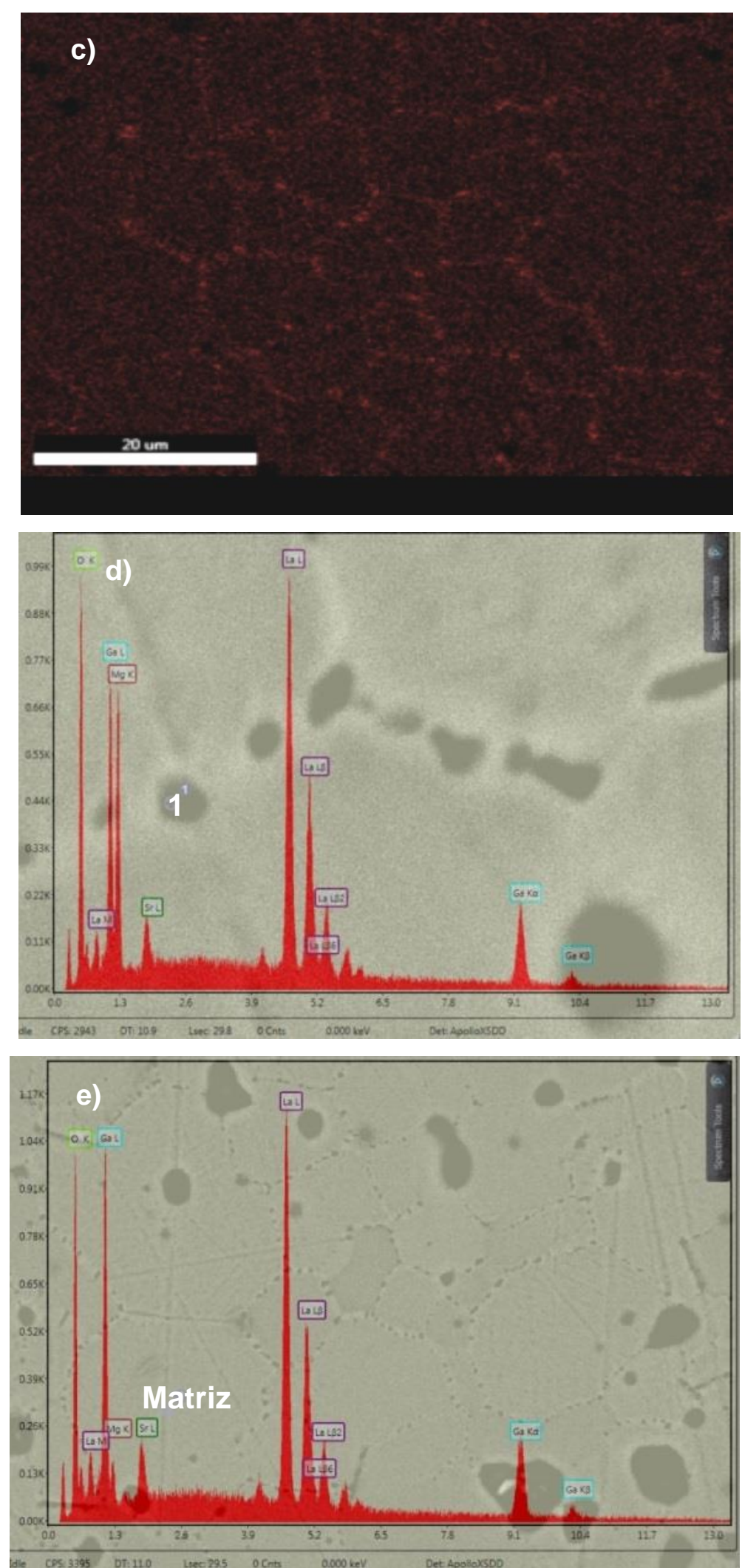

Figura 45: (cont.) c) mapeamento do Mg por EDS, d) espectro dos elementos da região 1 , e) espectro dos elementos da matriz, das amostras preparadas pelo método de complexação de cátions sinterizadas a $1450^{\circ} \mathrm{C} / 4 \mathrm{~h}$. (VermelhoMg; verde-Sr; azul-Gálio e roxo-La). As regiões c e d são ampliações da Figura $45 a$. 
Conforme discutido anteriormente, a microestrutura de amostras sinterizadas e preparadas por complexação de cátions é homogênea com relação à forma e tamanho, Figura 45a.

A partir da análise de mapeamento, Figura 45b, pode-se perceber uma uniformidade da distribuição dos elementos ( $\mathrm{La}, \mathrm{Sr}, \mathrm{Ga}, \mathrm{Mg}$ ) na matriz, ou seja, não há regiões com maior concentração de elementos, em conformidade com os resultados de DRX, Figura 31.

De acordo com o mapeamento para o elemento Mg, Figura $45 \mathrm{c}$, os grãos escuros observados na região de contorno de grão, Figura 45a correspondem a grãos de $\mathrm{MgO}$, confirmado pelo espectro da Figura 45d. Outros autores também reportaram a presença de $\mathrm{MgO}[25,83]$ para outros métodos químicos. O mapeamento da matriz, Figura 45e, confirma a homogeneidade da amostra.

A análise de mapeamento por EDS permitiu confirmar a formação de fases secundárias nas amostras preparadas por mistura de óxidos, além de identificar grãos de MgO. Para as amostras preparadas por complexação de cátions, a única fase secundária detectada foram os grãos de $\mathrm{MgO}$ nas regiões dos contornos de grãos.

\section{Espectroscopia de impedância}

Por fim, serão mostrados e discutidos os principais resultados de medidas da condutividade elétrica de amostras selecionadas. As Figuras 46-52 mostram diagramas de impedância típicos para amostras sinterizadas preparadas pelo método de mistura de óxidos e pelo método de complexação de cátions. Nesses diagramas é plotada a parte imaginária em função da parte real da impedância medida, normalizadas pelas dimensões das amostras. Desta forma, os diâmetros dos semicírculos correspondem as resistividades do grão (alta frequência) e contornos de grão (baixa frequência). Os números nos diagramas indicam o logaritmo decimal da frequência $(\mathrm{em} \mathrm{Hz})$. 
A Figura 46 mostra diagramas de impedância para as amostras sinterizadas a $1450{ }^{\circ} \mathrm{C} / 4 \mathrm{~h}$ preparadas pelo método de misturas de óxidos para todas as rotas empregadas.

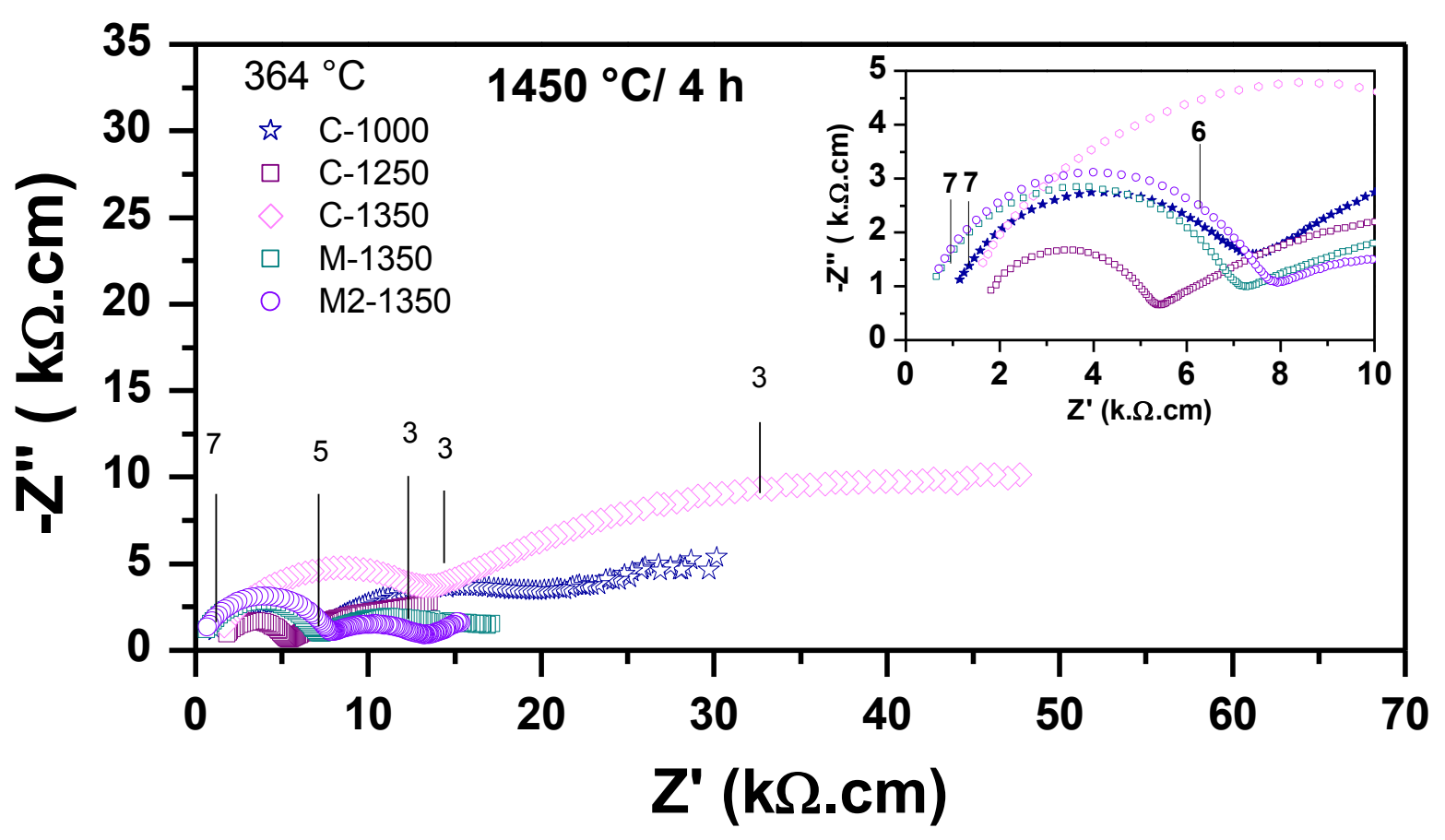

Figura 46: Diagramas de impedância das amostras preparadas pelo método de mistura de óxidos e sinterizadas a $1450 \stackrel{\circ}{\mathrm{C}} / 4 \mathrm{~h}$. Gráfico interno: Região de alta frequência.

A resistividade dos grãos é inferior para as amostras com calcinações sucessivas a $1250^{\circ} \mathrm{C}$ e superior para as amostras com calcinações sucessivas a $1350{ }^{\circ} \mathrm{C}$ e similar para as demais. A resistividade dos contornos de grãos para as amostras com calcinações sucessivas a $1350^{\circ} \mathrm{C}$ é superior às demais rotas. Esse fenômeno está provavelmente associado com as fases secundárias, em conformidade com os resultados de difração de raios $X$, Figura 20.

Com base nos resultados obtidos, para as amostras preparadas pelo método de mistura de óxidos foram selecionadas amostras com calcinações sucessivas a $1250{ }^{\circ} \mathrm{C}$, e amostras com duas calcinações a $1350{ }^{\circ} \mathrm{C}$ com moagens intercaladas, para verificar os efeitos das fases secundárias na condutividade elétrica do LSGM. 
A Figura 47 mostra diagramas de impedância para amostras sinterizadas em diferentes temperaturas com tempo de patamar fixo de $2 \mathrm{~h}$, com calcinações sucessivas a $1250^{\circ} \mathrm{C}$.

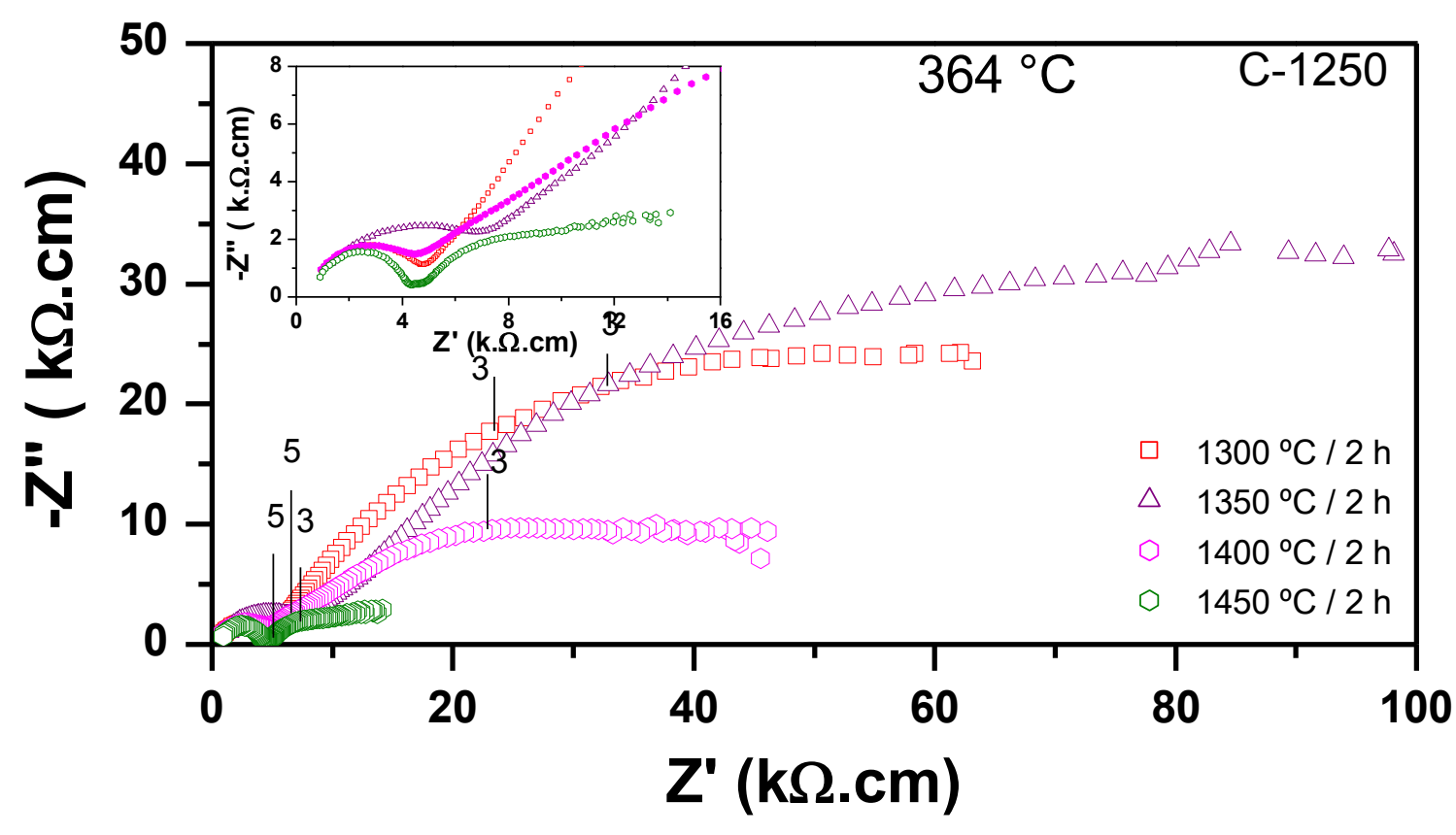

Figura 47: Diagramas de impedância das amostras com calcinações sucessivas a $1250{ }^{\circ} \mathrm{C}$ e sinterizadas em diferentes temperaturas de sinterização com patamar fixo de $2 \mathrm{~h}$. Gráfico interno: Região de alta frequência.

A resistividade do grão (Gráfico interno) e do contorno de grão das amostras sinterizadas a $1450^{\circ} \mathrm{C}$ foram inferiores às das amostras sinterizadas nas demais condições. As amostras sinterizadas a $1350{ }^{\circ} \mathrm{C}$ e $1300{ }^{\circ} \mathrm{C}$ apresentaram superior resistividade dos grãos e contornos de grãos. Essas amostras possuem inferior densidades quando comparado as demais amostras.

A Figura 48 mostra diagramas de impedância para amostras sinterizadas em diferentes temperaturas com tempo de patamar fixo de $2 \mathrm{~h}$ com duas calcinações a $1350^{\circ} \mathrm{C}$ com moagens intercaladas. 


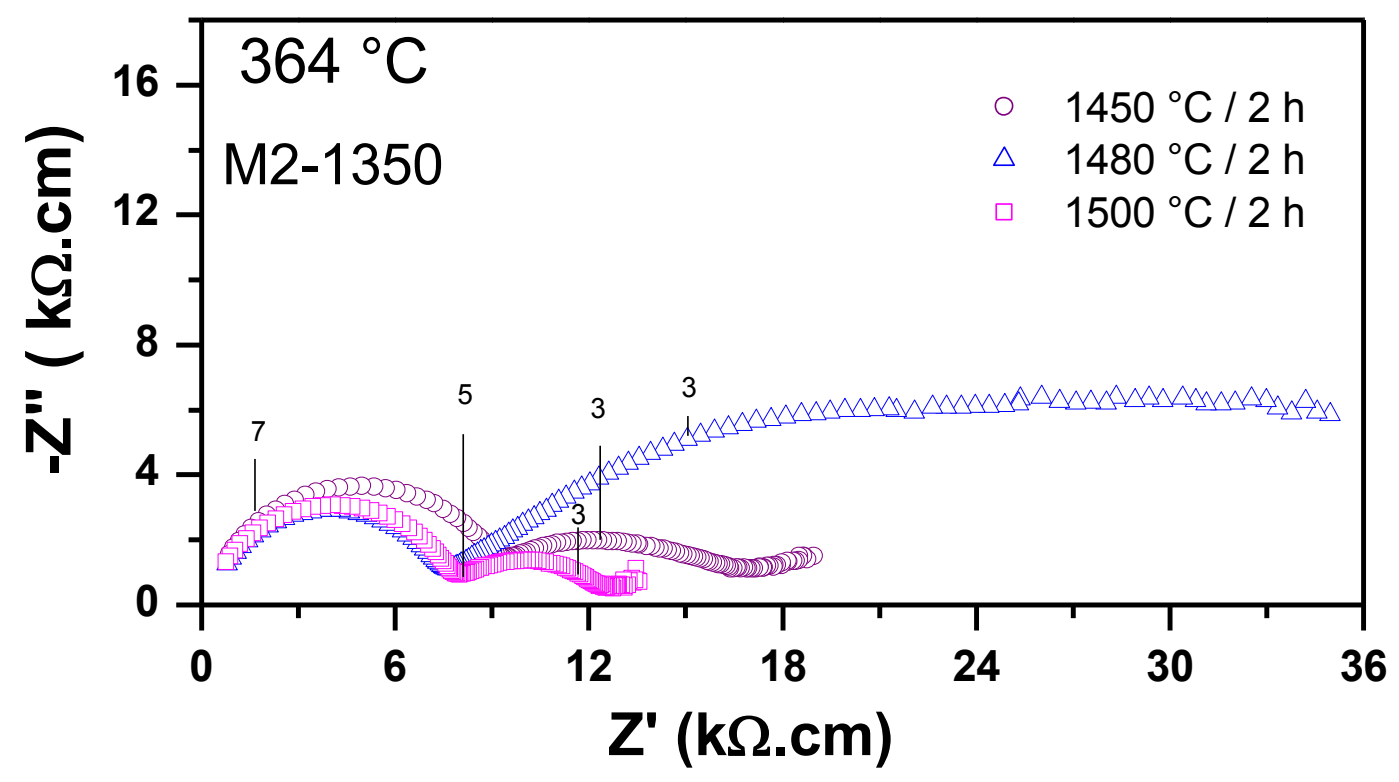

Figura 48: Diagramas de impedância das amostras com duas calcinações a $1350^{\circ} \mathrm{C}$ com moagens intercaladas e sinterizadas em diferentes temperaturas com o tempo de patamar fixo de $2 \mathrm{~h}$.

A resistividade do grão nas amostras sinterizadas a 1480 e $1500{ }^{\circ} \mathrm{C}$ com tempo de patamar fixo de $2 \mathrm{~h}$ foram similares e para $1450{ }^{\circ} \mathrm{C}$ foi levemente superior. A resistividade dos contornos de grãos foi superior para $1480^{\circ} \mathrm{C}$, sem definição do semicírculo e a amostra sinterizada a $1500{ }^{\circ} \mathrm{C}$ apresentou menor resistividade no contorno de grão. Esse resultado já era esperado, pois com aumento da temperatura de sinterização ocorre o crescimento do tamanho médio de grãos e a diminuição da fração de interfaces do contorno de grão.

Também foram realizadas medidas variando o tempo de sinterização com a temperatura fixa de $1450^{\circ} \mathrm{C}$ para as amostras com duas calcinações a $1350^{\circ} \mathrm{C}$ com moagens intercaladas, Figura 49. 


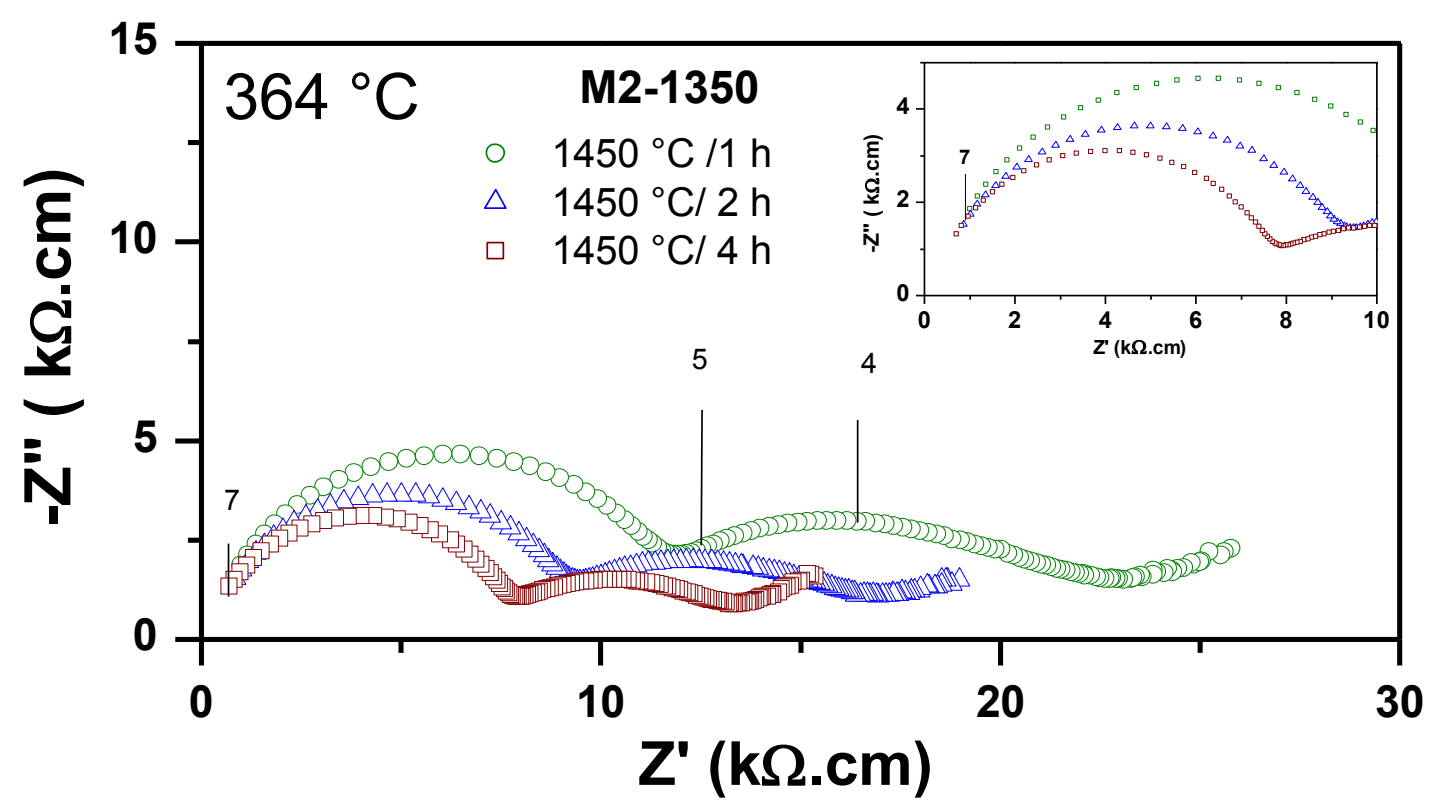

Figura 49: Diagramas de impedância das amostras com duas calcinações a $1350^{\circ} \mathrm{C}$ com moagens intercaladas e sinterizadas na temperatura de $1450{ }^{\circ} \mathrm{C}$ variando o tempo de patamar. Gráfico interno: Região de alta frequência.

A resistividade do grão e contorno de grão para as amostras com tempo de patamar de $4 \mathrm{~h}$ foi maior do que para as amostras com tempo de patamar de 1 e $2 \mathrm{~h}$.

A Figura 50 mostra diagramas de impedância para as amostras com calcinações sucessivas a $1250{ }^{\circ} \mathrm{C}$, e com duas calcinações a $1350^{\circ} \mathrm{C}$ com moagens intercaladas, e sinterizadas a $1450^{\circ} \mathrm{C} / 4 \mathrm{~h}$ e $1500^{\circ} \mathrm{C} / 6 \mathrm{~h}$.

A resistividade das amostras sinterizadas a $1500^{\circ} \mathrm{C} / 6 \mathrm{~h}$ preparadas pelas duas rotas são similares e inferiores as amostras sinterizadas a $1450{ }^{\circ} \mathrm{C} / 4 \mathrm{~h}$ com duas calcinações a $1350^{\circ} \mathrm{C}$ e moagens intercaladas, e pouco superior as amostras sinterizadas a $1450^{\circ} \mathrm{C} / 4 \mathrm{~h}$ com calcinações sucessivas a $1250^{\circ} \mathrm{C}$.

Para as amostras preparadas pelo método de mistura de óxidos, a resistividade do grão e contorno de grão foi influenciada com as fases secundárias nas condições de sinterização utilizadas. Elevada resistividade na região dos contornos de grãos está provavelmente associada a presença das fases secundárias [10]. 


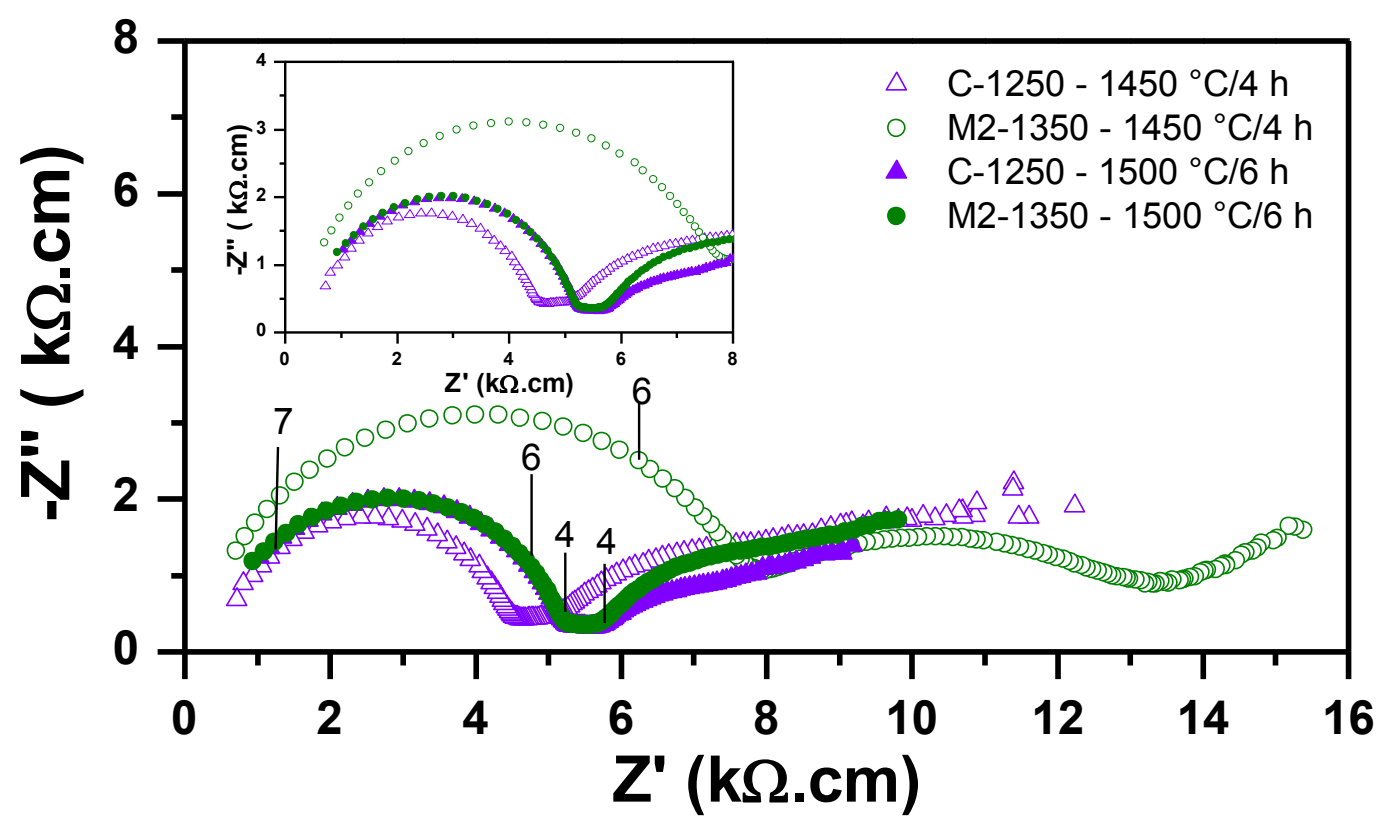

Figura 50: Diagramas de impedância das amostras com calcinações sucessivas a $1250{ }^{\circ} \mathrm{C}$ e com duas calcinações a $1350{ }^{\circ} \mathrm{C}$ com moagens intercaladas e sinterizadas a $1450^{\circ} \mathrm{C} / 4 \mathrm{~h}$ e $1500^{\circ} \mathrm{C} / 6 \mathrm{~h}$. Gráfico interno: Região de alta frequência.

Foram realizadas medidas elétricas para as amostras preparadas pelo método de complexação de cátions variando a temperatura de sinterização e o tempo de patamar, respectivamente.

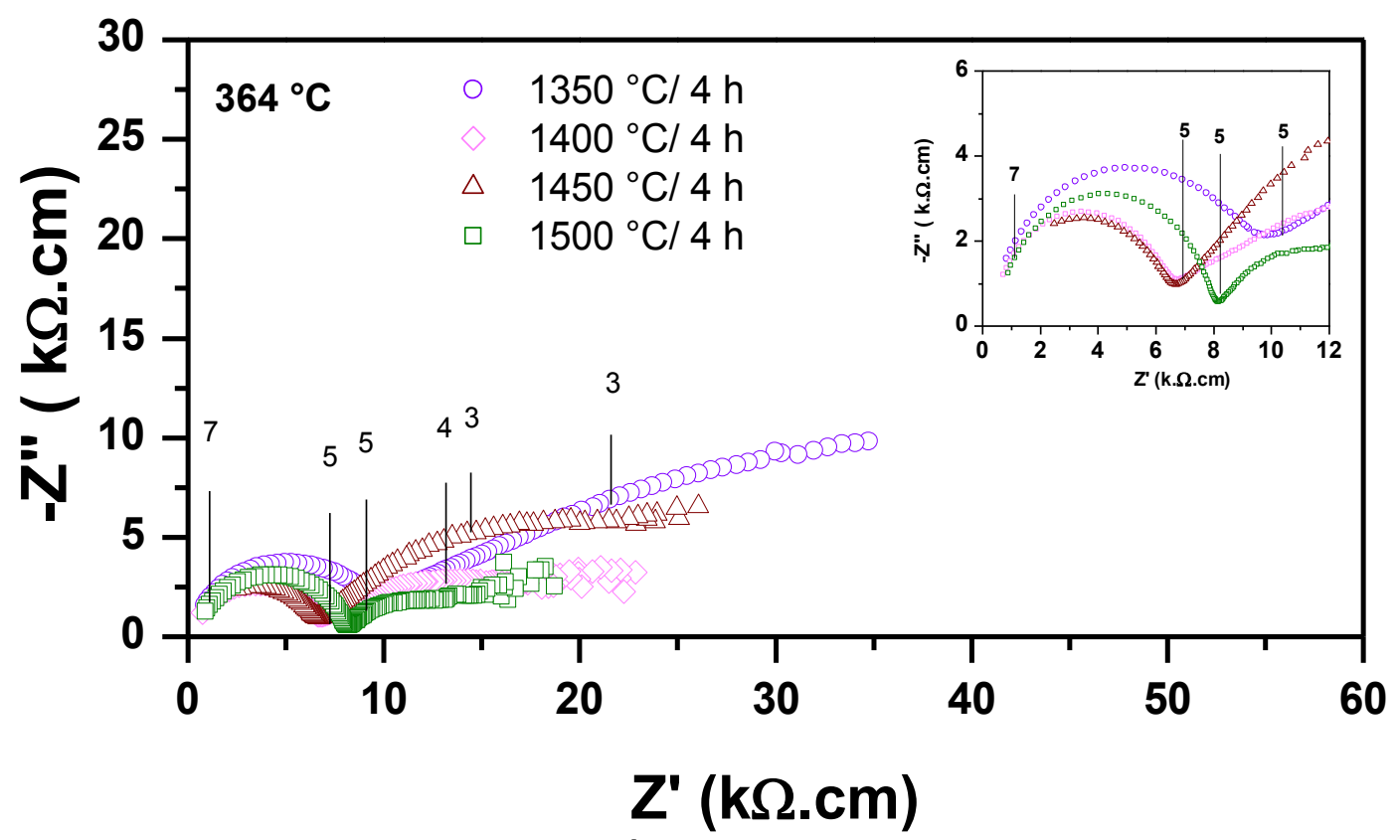

Figura 51: Diagramas de impedância das amostras sinterizadas preparadas pelo método de complexação de cátions para o tempo de patamar fixo de $4 \mathrm{~h}$ variando a temperatura de sinterização. Gráfico interno: Região de alta frequência. 
A resistividade do grão para as amostras sinterizadas a 1400 e $1450{ }^{\circ} \mathrm{C}$ são similares e inferiores àquela sinterizada a 1500 e $1350^{\circ} \mathrm{C}$. A resistividade do contorno de grão foi superior para a amostra sinterizada a $1350{ }^{\circ} \mathrm{C}$, e a amostra sinterizada a $1500{ }^{\circ} \mathrm{C}$ apresentou a menor resistividade. Observa-se que não houve definição do semicírculo do contorno de grão para as todas as condições utilizadas pelo método de complexação de cátions. Isso provavelmente está associado aos grãos de $\mathrm{MgO}$ na região dos contornos de grãos, confirmado por EDS, Figura 45.

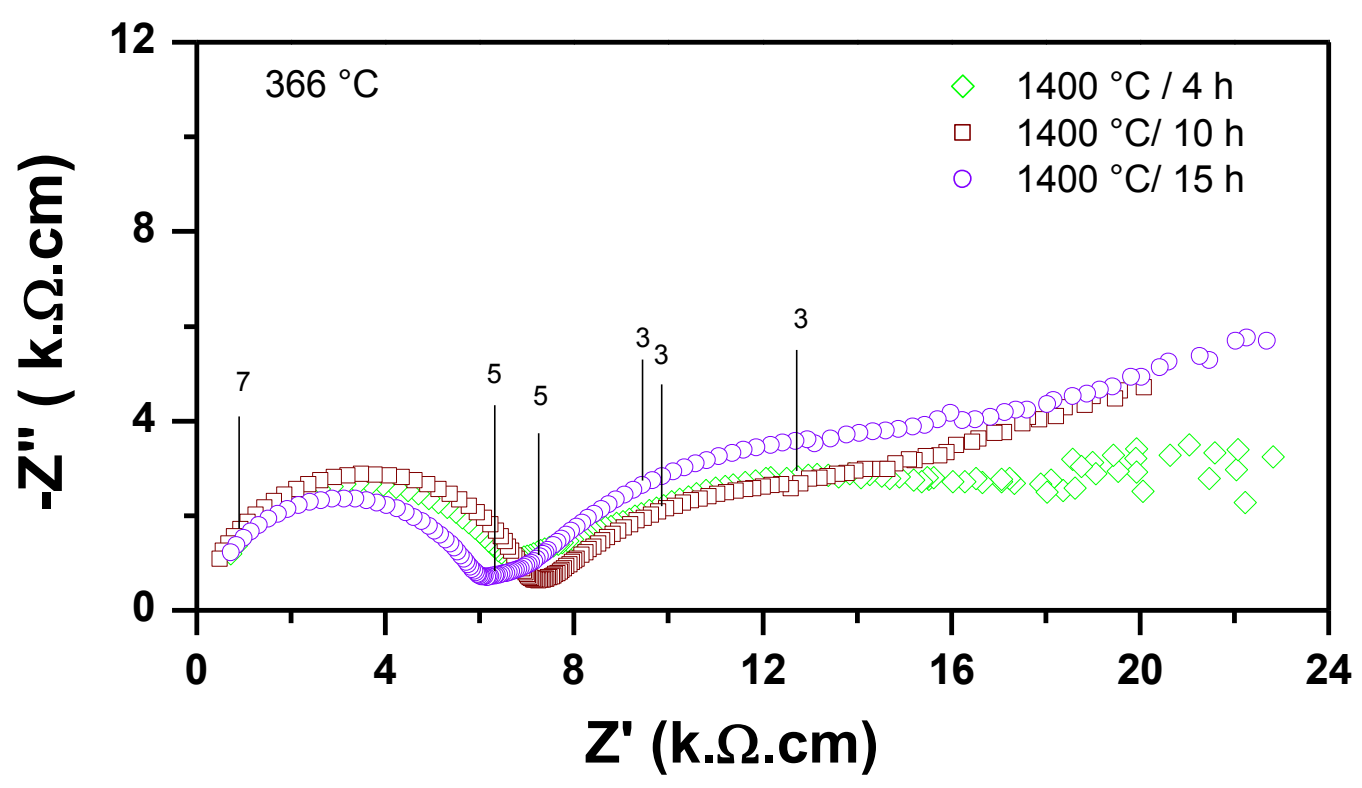

Figura 52: Diagramas de impedância das amostras sinterizadas preparadas pelo método de complexação de cátions para a temperatura fixa de $1400{ }^{\circ} \mathrm{C}$ variando o tempo de patamar.

Para as amostras preparadas pelo método de complexação de cátions e sinterizadas na temperatura de patamar fixa de $1400^{\circ} \mathrm{C}$, aquela com tempo de patamar de $15 \mathrm{~h}$ apresentou menor resistividade do grão. Observa-se que variando o tempo de patamar também não houve definição do semicírculo relacionado a resistividade dos contornos de grãos.

A análise dos resultados de medidas da condutividade elétrica em diversas condições, para as amostras preparadas pelos dois métodos de síntese permitiu construir os gráficos de Arrhenius da condutividade elétrica. 
A Figura 53 mostra o comportamento da condutividade dos grãos e contornos de grãos para as amostras obtidas pelos dois métodos, sinterizadas a $1450^{\circ} \mathrm{C} / 4 \mathrm{~h}$.
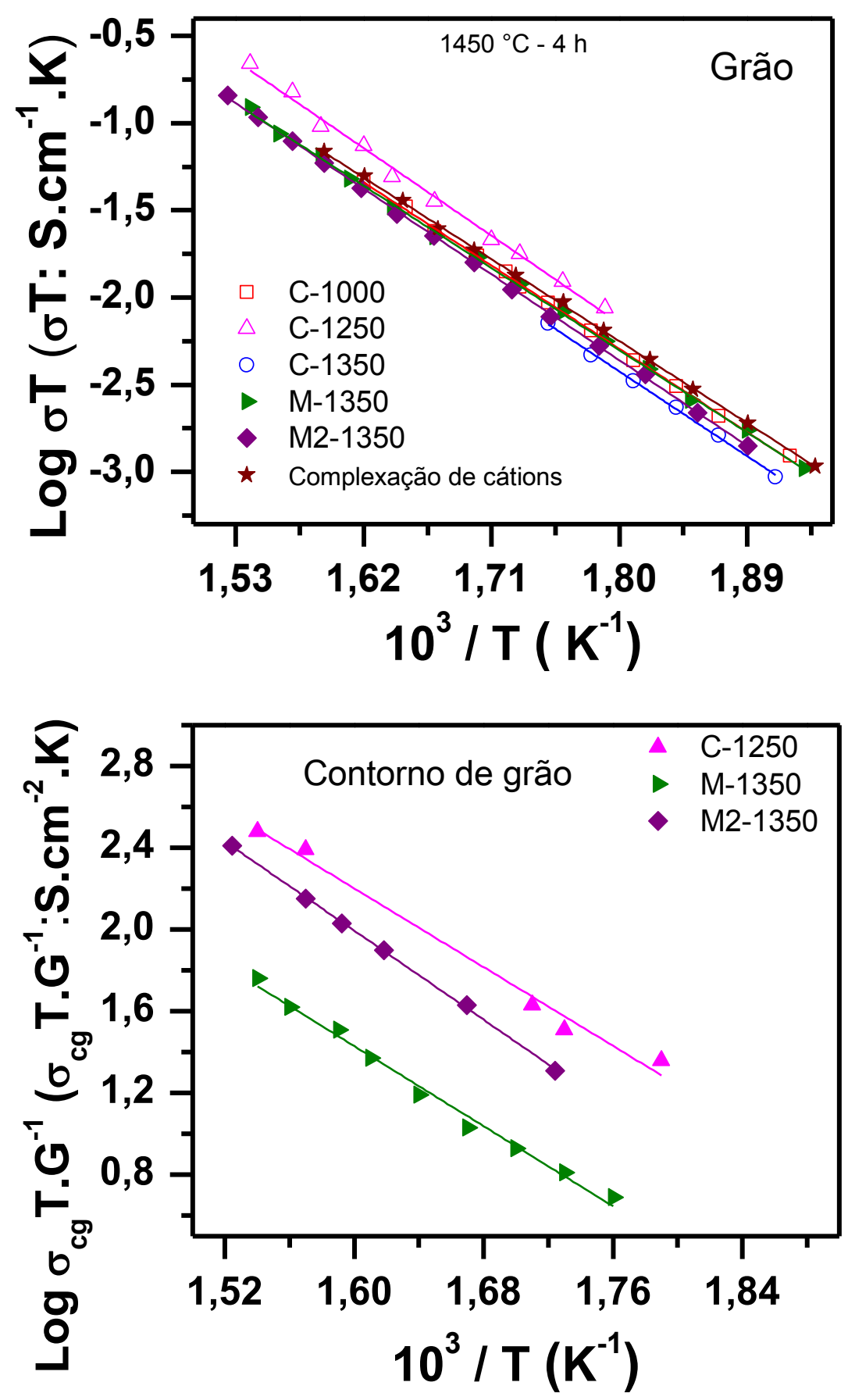

Figura 53: Gráficos de Arrhenius da condutividade elétrica dos grãos (superior) e contornos de grãos (inferior) das amostras preparadas por mistura de óxidos e pelo método de complexação de cátions e sinterizadas a $1450 \stackrel{\circ}{\circ} / 4 \mathrm{~h}$.

Maior condutividade para os grãos e contornos de grãos foi obtida para as amostras preparadas com calcinações sucessivas a $1250^{\circ} \mathrm{C}$. Este resultado 
pode ser associado com a composição de fases do material. As amostras preparadas com calcinações sucessivas a $1250^{\circ} \mathrm{C}$ apresentam predominância da fase secundária $\mathrm{SrLaGa}_{3} \mathrm{O}_{7}$ e menor quantidade das demais fases.

Observa-se que as amostras preparadas com calcinações sucessivas a $1350{ }^{\circ} \mathrm{C}$ apresenta menor condutividade iônica dos grãos e que não há variação da para as demais rotas preparadas por mistura de óxidos e pelo método de complexação. Para algumas condições não foi possível construir o gráfico de Arrhenius do contorno de grão.

A Figura 54 mostra a condutividade elétrica dos grãos e contornos de grão para as amostras preparadas com calcinações sucessivas a $1250{ }^{\circ} \mathrm{C}$ e preparadas com duas calcinações a $1350{ }^{\circ} \mathrm{C}$ com moagens intercaladas, e sinterizadas a $1450{ }^{\circ} \mathrm{C} / 4 \mathrm{~h}$ e $1500{ }^{\circ} \mathrm{C} / 6 \mathrm{~h}$, respectivamente. A condutividade iônica intergranular foi normalizada pelo tamanho médio de grãos.

As amostras sinterizadas a $1500{ }^{\circ} \mathrm{C} / 6 \mathrm{~h}$ preparadas pelas duas rotas e amostras sinterizadas a $1450{ }^{\circ} \mathrm{C} / 4 \mathrm{~h}$ preparadas com calcinações sucessivas a $1250{ }^{\circ} \mathrm{C}$ apresentam condutividade iônica do grão similar e superior à das amostras sinterizadas a $1450{ }^{\circ} \mathrm{C} / 4 \mathrm{~h}$ com duas calcinações a $1350{ }^{\circ} \mathrm{C}$ com moagens intercaladas. $\mathrm{O}$ aumento do teor da fase $\mathrm{SrLaGa}_{3} \mathrm{O}_{7}$ não prejudicou a condutividade nas amostras sinterizadas a $1500^{\circ} \mathrm{C} / 6 \mathrm{~h}$, ao contrário, favoreceu o aumento da condutividade intergranular, Figura 54.

As fases secundárias possuem condutividade iônica relativamente baixa (duas a três ordens de grandeza inferior) comparadas a matriz de LSGM. Entretanto, a fase não estequiométrica $\mathrm{La}_{1+} \times \mathrm{SrGa}_{3} \mathrm{O}_{7}$ apresenta condutividade iônica similar à do LSGM [60]. Assim, o resultado da Figura 54 sugere que a fase secundária formada é $\mathrm{La}_{1+} \mathrm{SrGa}_{3} \mathrm{O}_{7}$ que está de acordo com 0 mapeamento realizado por EDS, Figuras 42 e 43. 

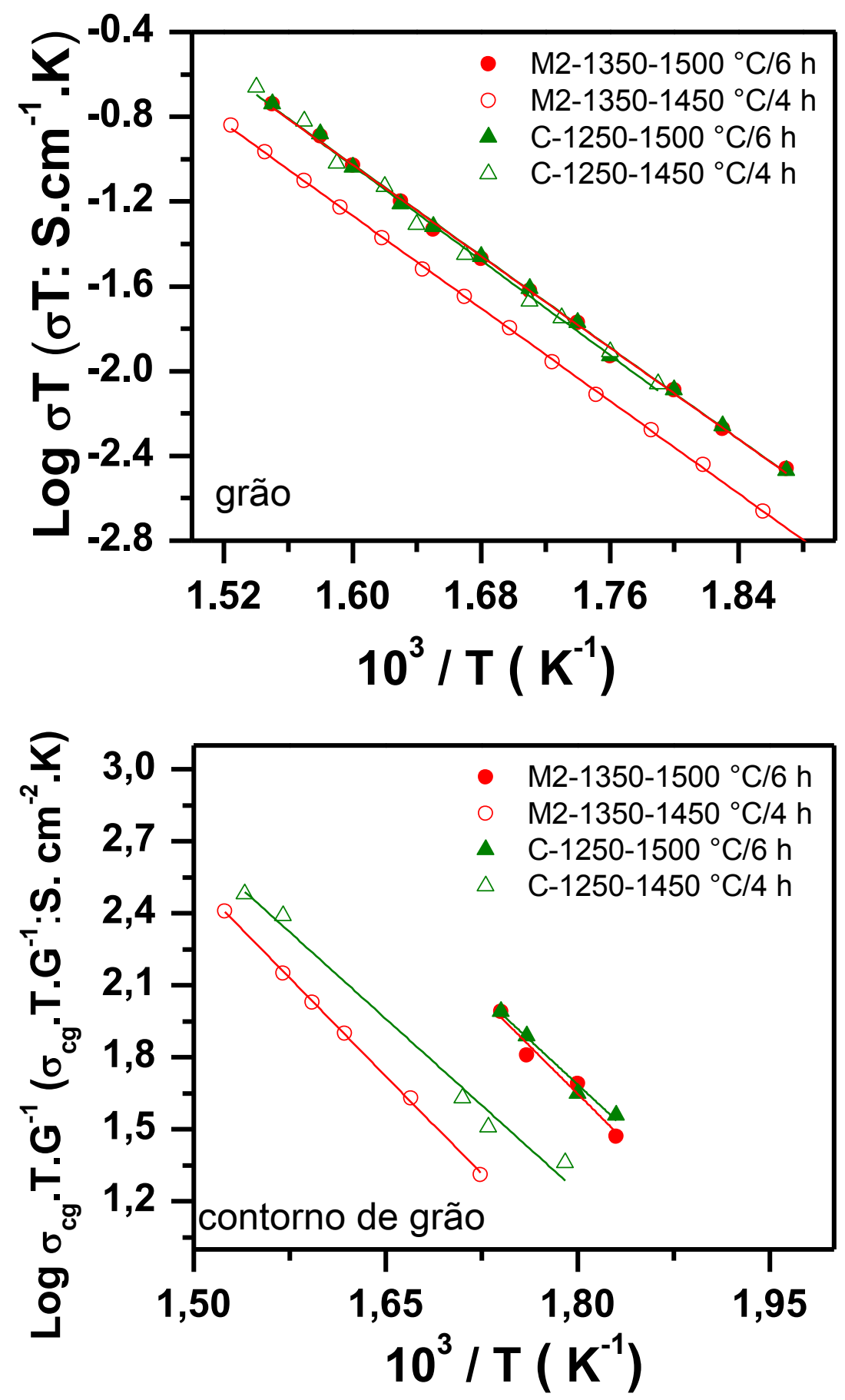

Figura 54: Gráficos de Arrhenius da condutividade elétrica dos grãos (grãos) e contornos de grãos (inferior) das amostras sinterizadas a $1450^{\circ} \mathrm{C} / 4 \mathrm{~h}$ e 1500 ${ }^{\circ} \mathrm{C} / 6 \mathrm{~h}$ preparadas com calcinações sucessivas a $1250{ }^{\circ} \mathrm{C}$ e preparadas com duas calcinações a $1350^{\circ} \mathrm{C}$.

As Figuras 55 e 56 mostram o comportamento da condutividade dos grãos para amostras preparadas pelo método de complexação de cátions, com tempo de patamar fixo de $4 \mathrm{~h}$ variando a temperatura de sinterização, e para a temperatura fixa de $1400{ }^{\circ} \mathrm{C}$ variando o tempo de patamar, respectivamente. 


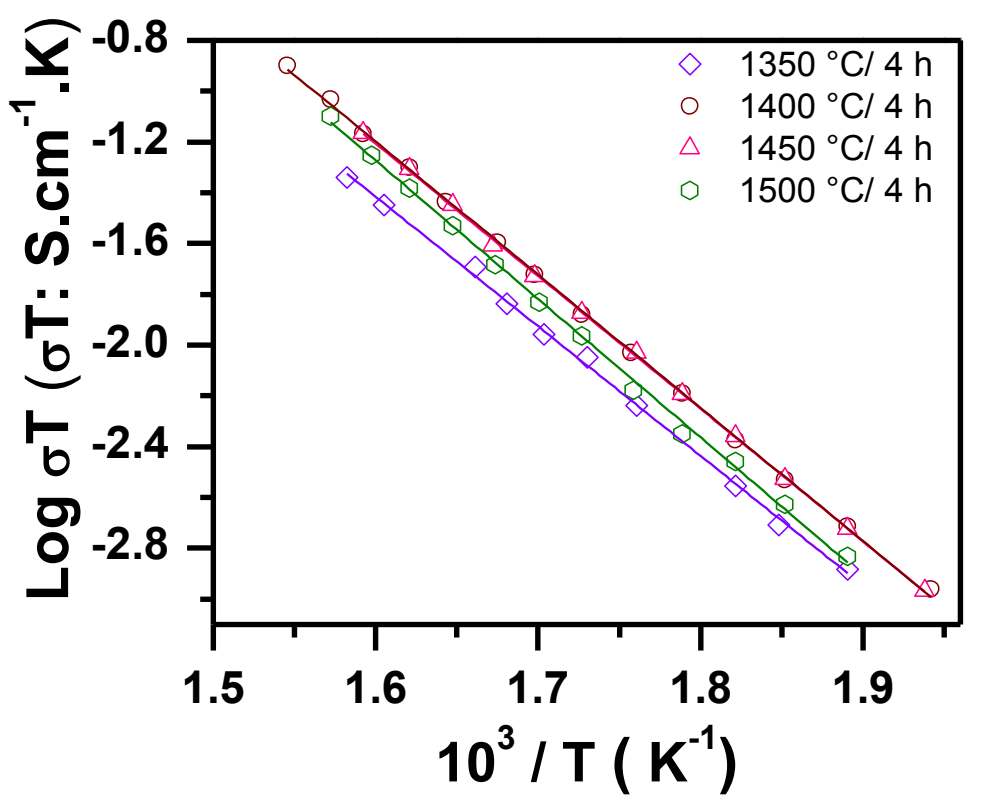

Figura 55: Gráficos de Arrhenius da condutividade elétrica dos grãos das amostras sinterizadas preparadas pelo método de complexação de cátions para o tempo de patamar fixo de $4 \mathrm{~h}$ variando a temperatura.

Amostras sinterizadas a 1400 e $1450^{\circ} \mathrm{C}$ apresentam condutividade iônica dos grãos similar e superior as amostras sinterizadas a $1350^{\circ} \mathrm{C}$ e $1500^{\circ} \mathrm{C}$. Isto ocorre porque a amostra sinterizada a $1350{ }^{\circ} \mathrm{C}$ possui menor densidade comparada às demais e as amostras sinterizadas a $1500{ }^{\circ} \mathrm{C}$ possui maior quantidade de precipitados de $\mathrm{MgO}$.

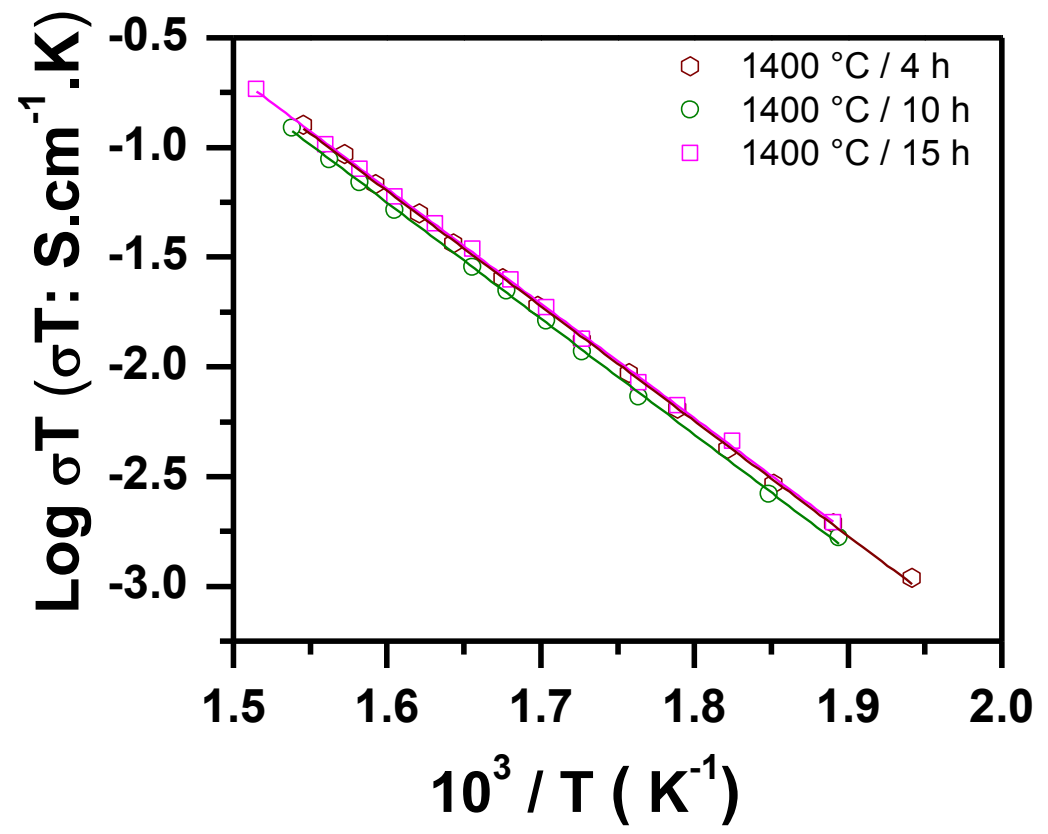

Figura 56: Gráficos de Arrhenius da condutividade elétrica dos grãos das amostras sinterizadas preparadas pelo método de complexação de cátions para a temperatura fixa de $1400^{\circ} \mathrm{C}$ variando o tempo de patamar. 
Para amostras preparadas pelo método de complexação de cátions variando o tempo, não apresenta variação significativa na condutividade do grão.

O LSGM preparado pelo método de complexação apresenta maiores valores de condutividade para as condições de sinterização intermediárias, ou seja, tempos e temperaturas longos prejudicam a condutividade, que está associado com o aumento da fração de precipitados de $\mathrm{MgO}$.

A Tabela XI lista os valores de energia de ativação do processo de condução para os grãos, contornos e total das amostras sinterizadas pelo método de mistura de óxidos e pelo método de complexação de cátions, e os valores de condutividade total das amostras sinterizadas pelo método de mistura de óxidos.

Tabela XI - Valores de energia de ativação do processo de condução dos grãos $\left(\mathrm{E}_{\mathrm{g}}\right)$ contornos de grão $\left(\mathrm{E}_{\mathrm{cg}}\right)$ e total $\left(\mathrm{E}_{\mathrm{T}}\right)$, para amostras preparadas pelo método de mistura de óxidos e pelo método de complexação de cátions (C) e valores de condutividade total na temperatura de $360^{\circ} \mathrm{C}$ para amostras preparadas pelo método de mistura de óxidos.

\begin{tabular}{|c|c|c|c|c|c|}
\hline $\begin{array}{l}\text { Método de } \\
\text { Síntese }\end{array}$ & $\begin{array}{c}\text { Condições de } \\
\text { Sinterização } \\
\left({ }^{\circ} \mathrm{C} / \mathrm{h}\right)\end{array}$ & $\begin{array}{c}E_{g} \\
(e V)\end{array}$ & $\begin{array}{l}E_{c g} \\
(e V)\end{array}$ & $\begin{array}{c}E_{T} \\
(e V)\end{array}$ & $\begin{array}{c}\sigma\left(10^{-5} \mathrm{~S} / \mathrm{cm}\right) \\
360^{\circ} \mathrm{C}\end{array}$ \\
\hline C- 1000 & $1450 / 1$ & $1,06 \pm 0,05$ & $1,05 \pm 0,05$ & $1,07 \pm 0,05$ & 5,87 \\
\hline C-1000 & $1450 / 4$ & $1,05 \pm 0,05$ & --- & ---- & --- \\
\hline C- 1250 & $1300 / 2$ & $0,87 \pm 0,05$ & $1,02 \pm 0,05$ & $0,96 \pm 0,05$ & 6,70 \\
\hline C-1250 & $1350 / 2$ & $0,96 \pm 0,05$ & $0,93 \pm 0,05$ & $0,86 \pm 0,05$ & 8,52 \\
\hline C-1250 & $1400 / 2$ & $0,93 \pm 0,05$ & $0,80 \pm 0,05$ & $0,87 \pm 0,05$ & 13,05 \\
\hline C-1250 & $1450 / 1$ & $1,00 \pm 0,05$ & $1,00 \pm 0,05$ & $0,89 \pm 0,05$ & 6,60 \\
\hline C-1250 & $1450 / 2$ & $1,05 \pm 0,05$ & $0,91 \pm 0,05$ & $0,97 \pm 0,05$ & 9,37 \\
\hline C- 1250 & $1450 / 4$ & $1,10 \pm 0,05$ & $0,90 \pm 0,05$ & $1,03 \pm 0,05$ & 13,80 \\
\hline C-1250 & $1500 / 6$ & $1,06 \pm 0,05$ & $1,03 \pm 0,05$ & $1,01 \pm 0,05$ & 14,14 \\
\hline C-1350 & $1450 / 1$ & $1,05 \pm 0,05$ & $1,21 \pm 0,05$ & $1,11 \pm 0,05$ & 5,73 \\
\hline C-1350 & $1450 / 4$ & $1,06 \pm 0,05$ & --- & --- & ---- \\
\hline$M-1350$ & $1450 / 1$ & $1,01 \pm 0,05$ & $1,01 \pm 0,05$ & $1,00 \pm 0,05$ & 3,42 \\
\hline M-1350 & $1450 / 4$ & $1,03 \pm 0,05$ & $0,96 \pm 0,05$ & $0,99 \pm 0,05$ & 3,54 \\
\hline M2-1350 & $1450 / 1$ & $1,04 \pm 0,05$ & $1,00 \pm 0,05$ & $1,01 \pm 0,05$ & 3,64 \\
\hline M2-1350 & $1450 / 2$ & $1,08 \pm 0,05$ & $1,09 \pm 0,05$ & $1,07 \pm 0,05$ & 4,72 \\
\hline M2-1350 & $1450 / 4$ & $1,08 \pm 0,05$ & $1,07 \pm 0,05$ & $1,06 \pm 0,05$ & 6,32 \\
\hline M2-1350 & $1500 / 2$ & $1,10 \pm 0,05$ & $1,23 \pm 0,05$ & $1,14 \pm 0,05$ & 7,13 \\
\hline M2-1350 & $1500 / 6$ & $1,06 \pm 0,05$ & $1,03 \pm 0,05$ & $1,01 \pm 0,05$ & 15,08 \\
\hline C & $1350 / 4$ & $1,01 \pm 0,05$ & --- & --- & --- \\
\hline C & $1400 / 4$ & $1,03 \pm 0,05$ & --- & --- & --- \\
\hline C & $1450 / 4$ & $1,03 \pm 0,05$ & --- & --- & --- \\
\hline C & $1500 / 4$ & $1,08 \pm 0,05$ & --- & --- & --- \\
\hline C & $1400 / 10$ & $1,04 \pm 0,05$ & --- & --- & --- \\
\hline $\mathrm{C}$ & $1400 / 15$ & $1,03 \pm 0,05$ & --- & --- & --- \\
\hline
\end{tabular}


Os valores de energia de ativação para a condutividade dos grãos, contornos de grãos e total praticamente não variam com as rotas utilizadas para o método de mistura de óxidos e para o método de complexação de cátions. Isso mostra que não ocorre mudanças nos mecanismos de condução, ou seja, as fases secundárias não modificam o mecanismo. Resultados similares de energia de ativação foram encontrados por outros autores para as amostras preparadas por mistura de óxidos [7, 82, 42, 56].

Como não foi obtida a condutividade dos contornos de grãos para 0 método de complexação de cátions, nas condições estudadas, não foi possível obter a condutividade total.

As amostras com calcinações sucessivas a $1250{ }^{\circ} \mathrm{C}$ apresentaram maiores valores de condutividade total, na temperatura de $360^{\circ} \mathrm{C}$, comparado com as demais rotas nas mesmas condições de sinterização. $\mathrm{O}$ aumento do tempo e temperatura aumenta a condutividade total.

\subsubsection{Sinterização Rápida}

Com o objetivo de obter cerâmicas densas e minimizar a formação de fases secundárias foi utilizado um método de sinterização denominado sinterização rápida ("Fast Firing").

As amostras com calcinações sucessivas a $1250{ }^{\circ} \mathrm{C}$, com duas calcinações a $1350{ }^{\circ} \mathrm{C}$ com moagens intercaladas e preparadas por complexação de cátions foram densificadas por sinterização rápida para verificar os efeitos da sinterização na composição de fase do material.

As Figuras 57, 58 e 59 mostram difratogramas de raios $X$ das amostras com calcinações sucessivas a $1250^{\circ} \mathrm{C}$, com duas calcinações a $1350^{\circ} \mathrm{C}$ com moagens intercaladas e preparadas pelo método de complexação de cátions, densificadas por sinterização rápida, respectivamente. 

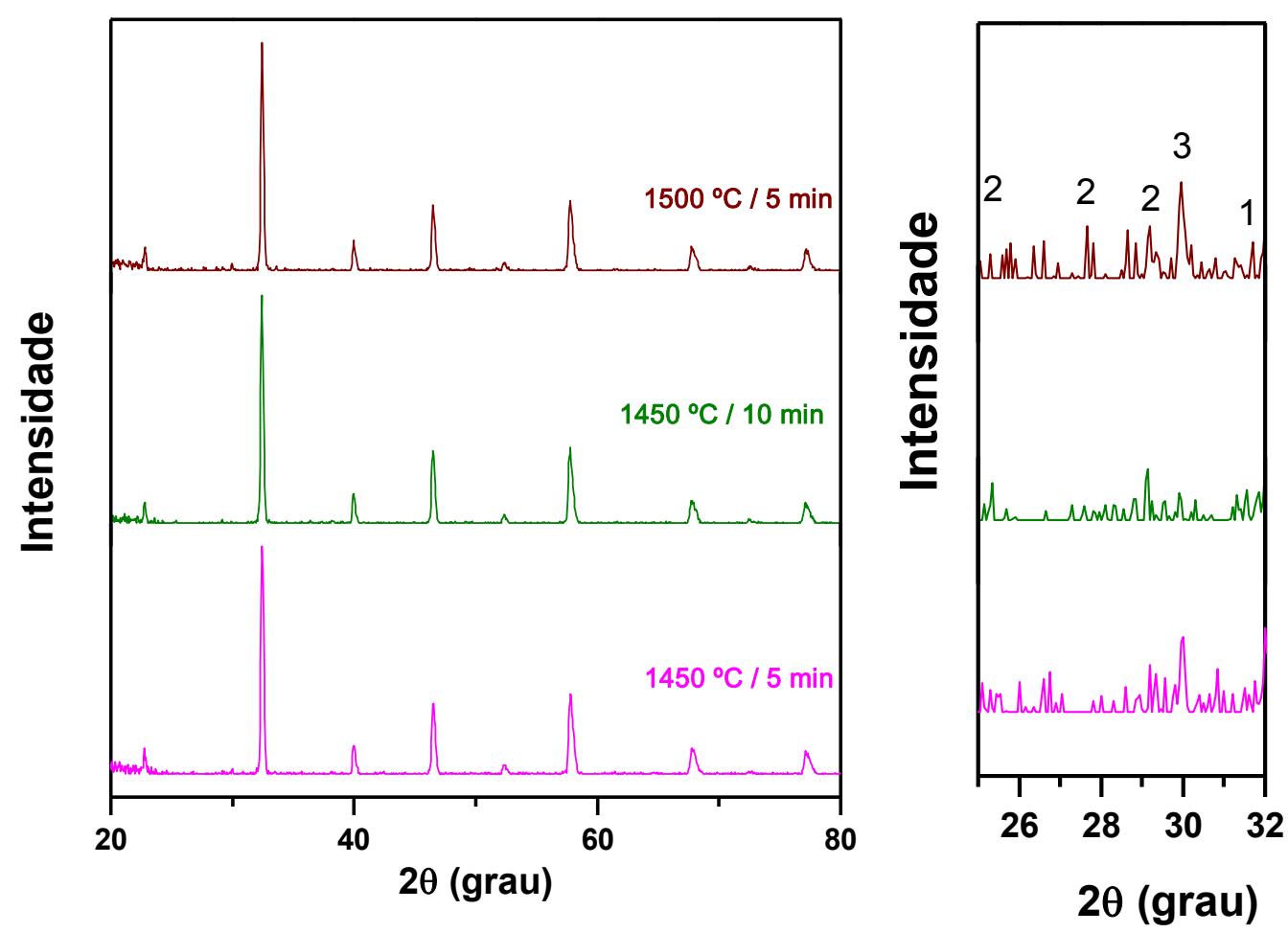

Figura 57: Difratogramas de raios $X$ das pastilhas com calcinações sucessivas a $1250^{\circ} \mathrm{C}$ após sinterização rápida na faixa de $2 \theta$ entre (esquerda) 20 e $80^{\circ} \mathrm{e}$ (direita) 25 e 32ㅇ - (*) LSGM, (1) $\mathrm{SrLaGaO}_{4}$, (2) $\mathrm{La}_{4} \mathrm{Ga}_{2} \mathrm{O}_{9}$ e (3) $\mathrm{SrLaGa}_{3} \mathrm{O}_{7}$.

A sinterização rápida utilizada para esta rota promoveu a formação da fase LSGM, mas não inibiu a formação das fases secundárias, porém possibilitou a diminuição do teor dessas fases, quando comparado as amostras sinterizadas convencionalmente, Figuras 23 e 24 . 

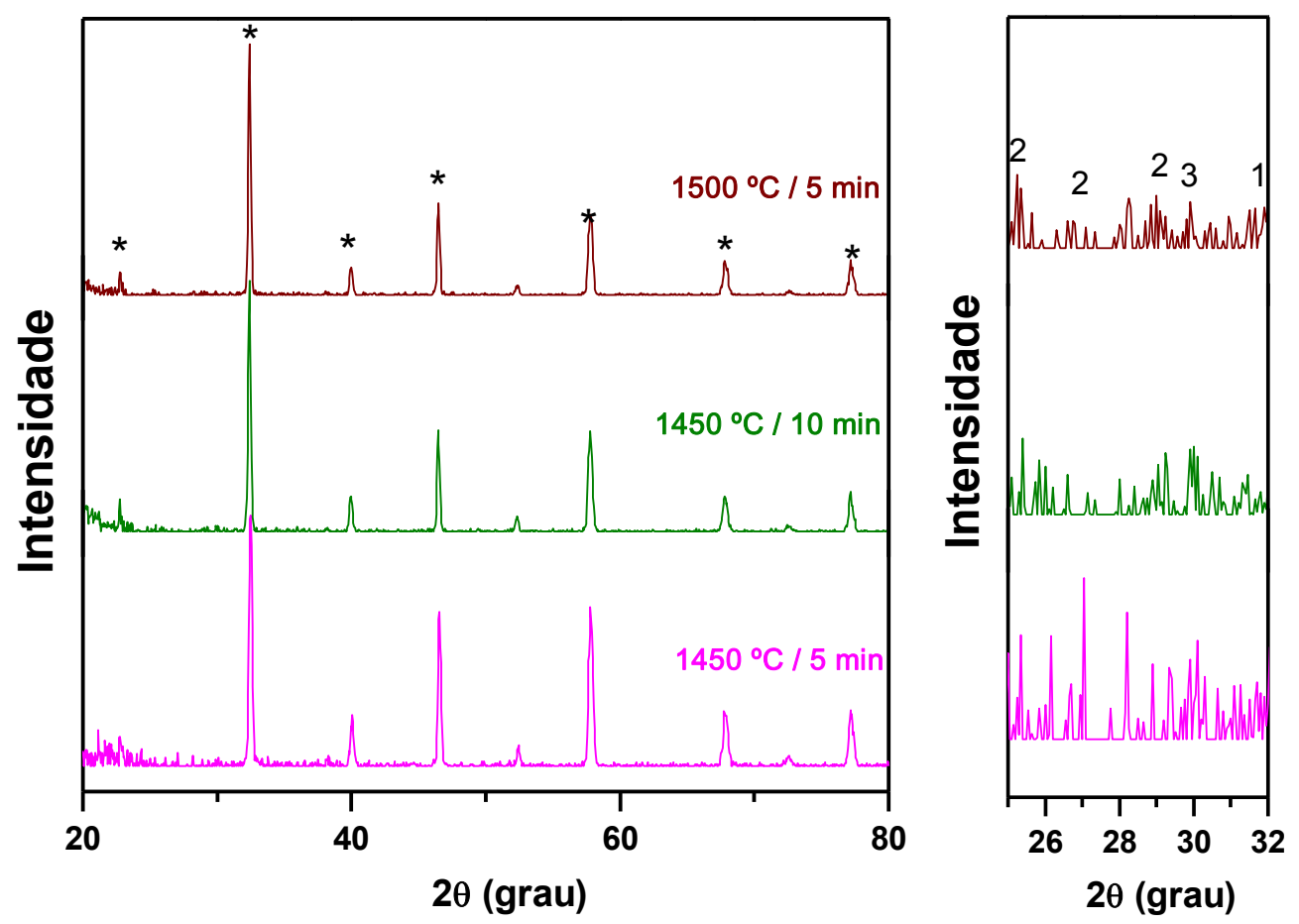

Figura 58: Difratogramas de raios $X$ das pastilhas com duas calcinações a $1350^{\circ} \mathrm{C}$ com moagens intercaladas após sinterização rápida na faixa de $2 \theta$ entre (esquerda) 20 e $80^{\circ}$ e (direita) 25 e 32으 - (*) LSGM, (1) SrLaGaO4, (2) $\mathrm{La}_{4} \mathrm{Ga}_{2} \mathrm{O}_{9}$ e (3) $\mathrm{SrLaGa}_{3} \mathrm{O}_{7}$.

Amostras preparadas com duas calcinações a $1350^{\circ} \mathrm{C}$ e moagens intercaladas, e obtidas por sinterização rápida apresentaram menor teor de fases secundárias, quando comparadas com as amostras preparadas por esta rota e sinterizadas convencionalmente, Figuras 29 e 30. Todas as condições apresentaram a fase LSGM.

As amostras preparadas pelo método de complexação e obtidas por sinterização rápida apresentaram a fase do LSGM, e teores de fases secundárias. Quando sinterizadas convencionalmente não foram detectados picos referentes às fases secundárias, Figuras 33 e 34 . A sinterização rápida favoreceu a formação das fases secundárias, neste caso, Figura 59. 

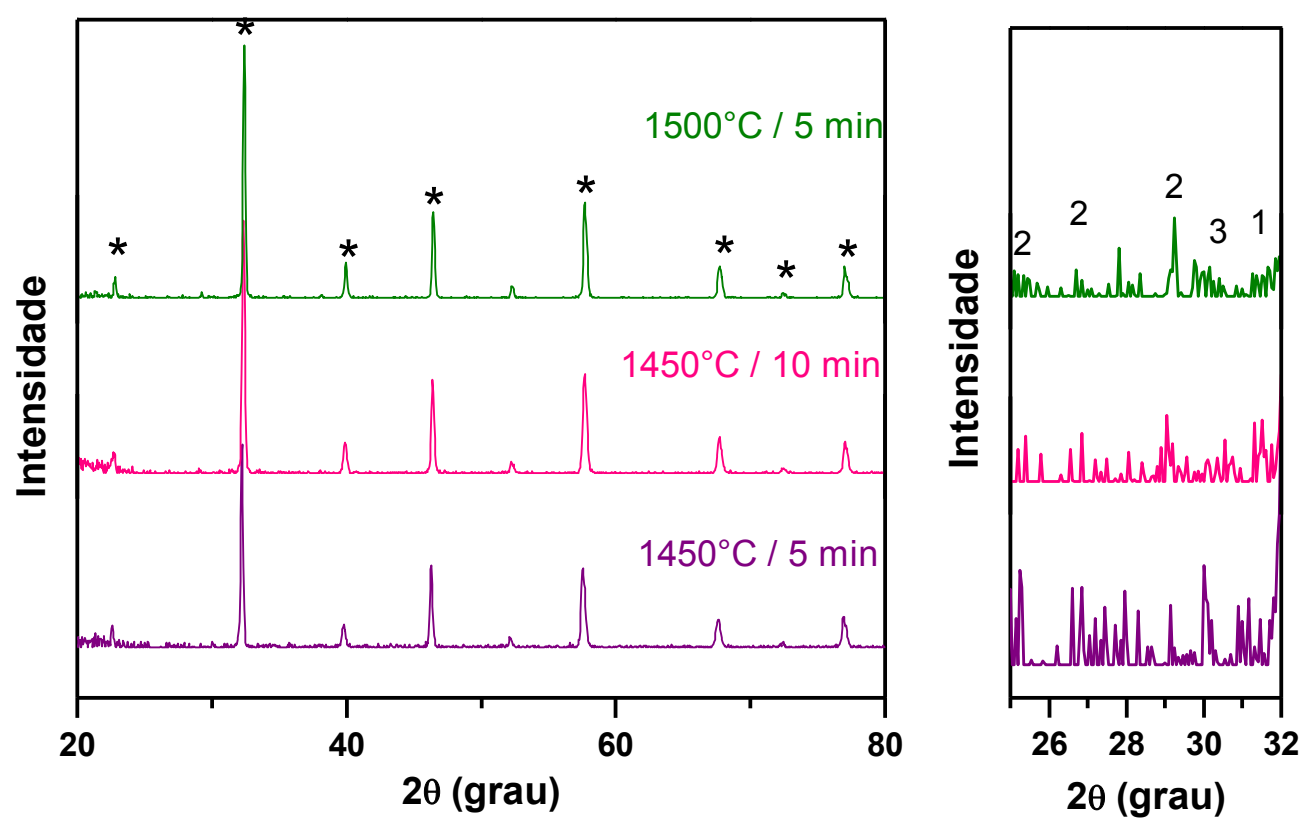

Figura 59: Difratogramas de raios $X$ das pastilhas preparadas pelo método de complexação de cátions após sinterização rápida na faixa de $2 \theta$ entre (esquerda) 20 e $80^{\circ}$ e (direita) 25 e 32ㅇ - (*) LSGM, (1) $\mathrm{SrLaGaO}_{4}$, (2) $\mathrm{La}_{4} \mathrm{Ga}_{2} \mathrm{O}_{9}$ e (3) $\mathrm{SrLaGa}_{3} \mathrm{O}_{7}$

A Tabela XII lista as densidades das amostras obtidas por sinterização rápida.

Tabela XII - Densidade relativa (\%) das amostras preparadas por mistura de óxidos com calcinações sucessivas a $1250^{\circ} \mathrm{C}$, com duas calcinações a 1350 ${ }^{\circ} \mathrm{C}$ com moagens intercaladas e preparadas por complexação de cátions e obtidas por sinterização rápida.

\begin{tabular}{lccc}
\hline $\begin{array}{c}\text { Condições } \\
\left({ }^{\circ} \mathbf{C} / \mathbf{m i n}\right)\end{array}$ & $\begin{array}{c}\text { Densidade } \\
(\mathbf{\%})\end{array}$ & $\begin{array}{c}\text { Densidade } \\
\mathbf{( \% )}\end{array}$ & $\begin{array}{c}\text { Densidade } \\
\mathbf{( \% )}\end{array}$ \\
\hline $1450 / 5$ & $91 \pm 1$ & $78 \pm 1$ & $88 \pm \pm 1$ \\
$1450 / 10$ & $93 \pm 1$ & $82 \pm 1$ & $89 \pm 1$ \\
$1500 / 5$ & $95 \pm 1$ & $84 \pm 1$ & $89 \pm 1$ \\
$1500 / 10$ & ---- & --- & $91 \pm 1$ \\
\hline \hline
\end{tabular}

As amostras preparadas com calcinações sucessivas a $1250{ }^{\circ} \mathrm{C}$ apresentaram densidades superiores às amostras preparadas com duas calcinações a $1350^{\circ} \mathrm{C}$ com moagens intercaladas, e preparadas pelo método de complexação de cátions quando obtidas por sinterização rápida. As densidades resultantes são inferiores àquelas das amostras sinterizadas convencionalmente, Tabelas VII e VIII. 
As Figuras 60, 61 e 62 mostram micrografias das amostras com calcinações sucessivas a $1250{ }^{\circ} \mathrm{C}$, com duas calcinações a $1350{ }^{\circ} \mathrm{C}$ com moagens intercaladas, e pelo método de complexação de cátions consolidadas por sinterização rápida, respectivamente.
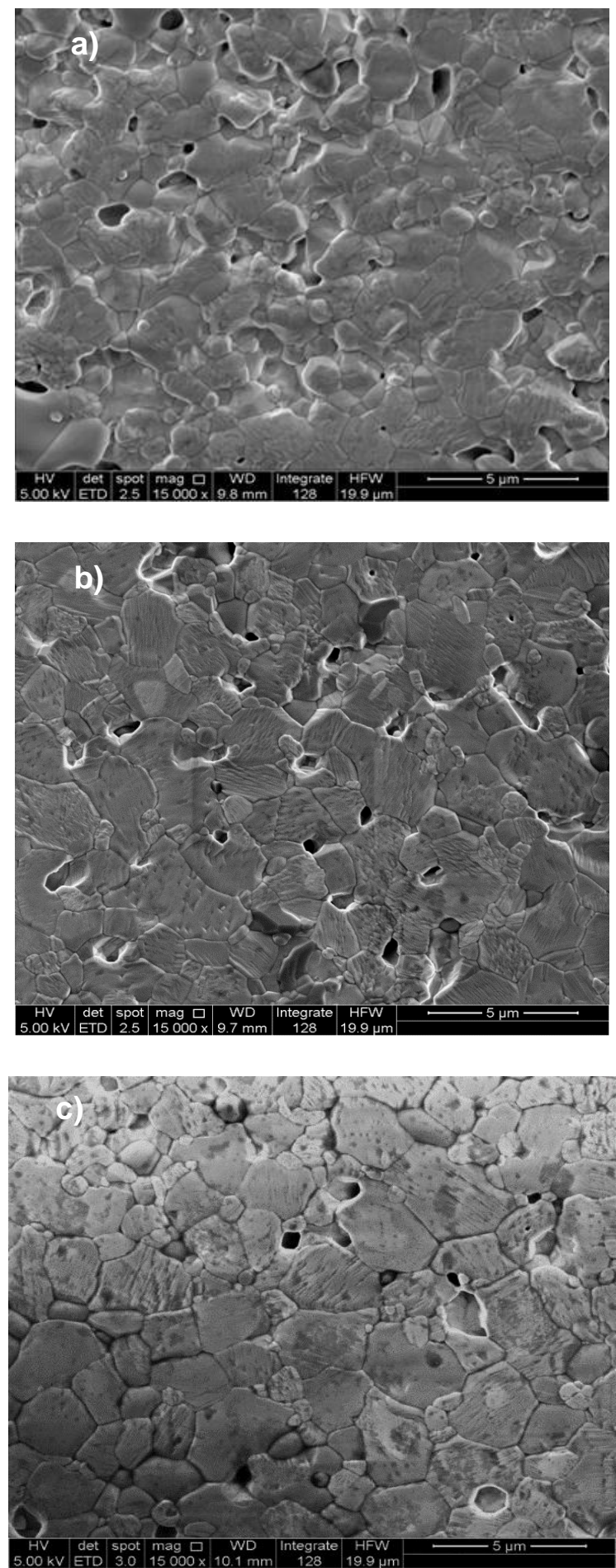

Figura 60: Micrografias obtidas em microscópio eletrônico de varredura de amostras preparadas pelo método de mistura de óxido com calcinações sucessivas a $1250{ }^{\circ} \mathrm{C}$ obtidas por sinterização rápida a) $1450{ }^{\circ} \mathrm{C} / 5 \mathrm{~min}$, b) $1450^{\circ} \mathrm{C} / 10 \mathrm{~min}$ e c) $1500^{\circ} \mathrm{C} / 5 \mathrm{~min}$. 
A microestrutura é bastante heterogênea, Figura 60. Observam-se grãos grandes e outros pequenos. $\mathrm{O}$ aumento da temperatura e do tempo promove uma diminuição da porosidade e um aumento no tamanho médio de grãos.
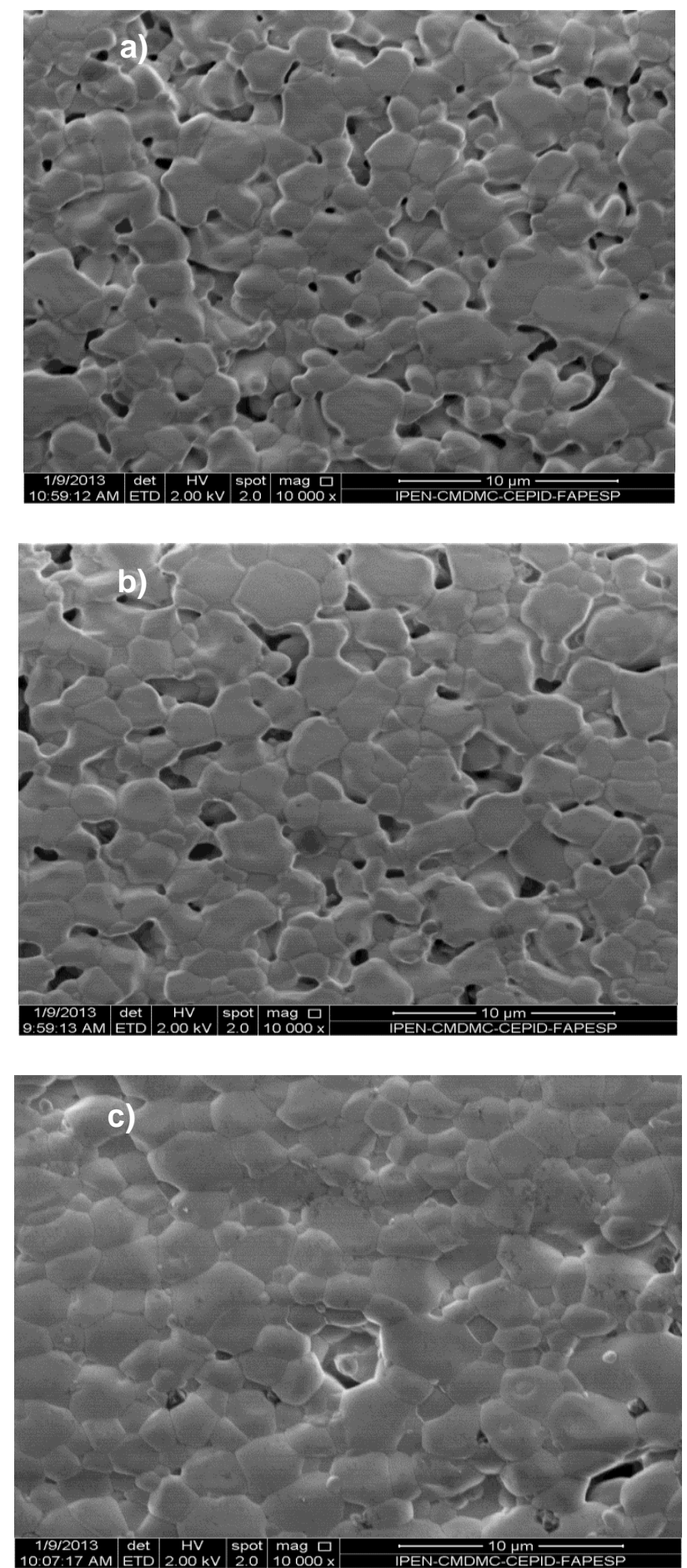

Figura 61: Micrografias obtidas em microscópio eletrônico de varredura de amostras preparadas pelo método de mistura de óxido com duas calcinações sucessivas a $1350{ }^{\circ} \mathrm{C}$ com moagens intercaladas obtidas por sinterização rápida a) $1450{ }^{\circ} \mathrm{C} / 5 \mathrm{~min}$, b) $1450^{\circ} \mathrm{C} / 10 \mathrm{~min} \mathrm{e} \mathrm{c)} 1500^{\circ} \mathrm{C} / 5 \mathrm{~min}$. 
O mesmo efeito ocorre nas amostras com duas calcinações a $1350{ }^{\circ} \mathrm{C}$ com moagens intercaladas, Figura 61.
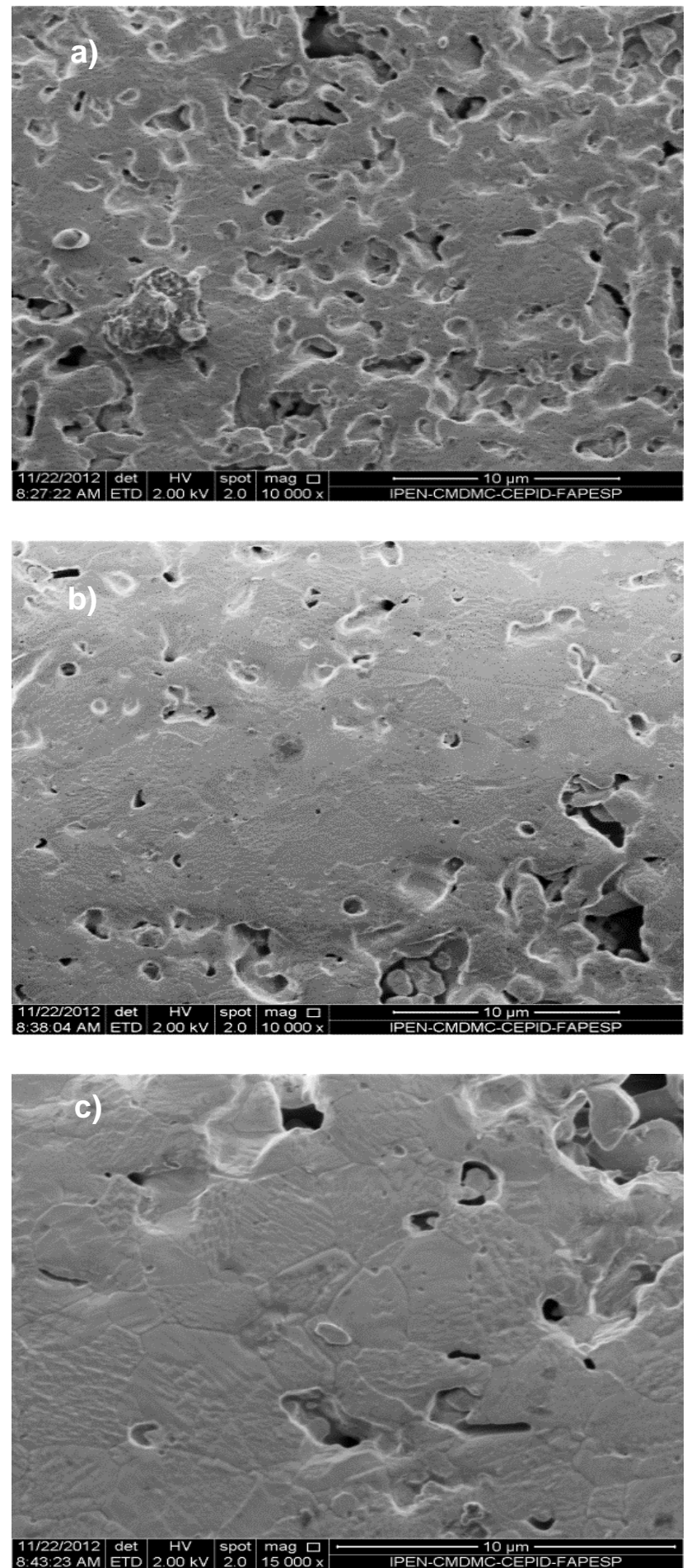

Figura 62: Micrografias obtidas em microscópio eletrônico de varredura de amostras preparadas pelo método de complexação obtidas por sinterização rápida a) $1450{ }^{\circ} \mathrm{C} / 5 \mathrm{~min}$, b) $1450^{\circ} \mathrm{C} / 10 \mathrm{~min}$ e c) $1500^{\circ} \mathrm{C} / 5 \mathrm{~min}$. 
As amostras preparadas pelo método de complexação de cátions, Figura 62, apresentam microestrutura homogênea com relação ao tamanho e morfologia. Observam-se grãos com aspecto rugoso e outros liso.

$\mathrm{Na}$ sinterização rápida as amostras exibem microrregiões com morfologias distintas e apresentam maior porosidade do que as amostras sinterizadas convencionalmente. O aumento da temperatura promove a densificação e o aumento do tamanho médio de grãos. Exceto pelo tamanho médio de grão a heterogeneidade e morfologia são similares as amostras sinterizadas convencionalmente.

A Tabela XIII mostra os valores de tamanho médio de grãos determinados pelo método de Mendelson [112], para as amostras preparadas pelo método de mistura de óxidos e pelo método de complexação obtidas por sinterização rápida.

Tabela XIII - Tamanho médio de grãos para as amostras preparadas por mistura de óxidos e complexação de cátions obtidas por sinterização rápida.

\begin{tabular}{cccc}
\hline Rota & $\begin{array}{c}\text { Condições de } \\
\text { sinterização } \\
\left({ }^{\circ} \mathbf{C} / \mathbf{h}\right)\end{array}$ & $\begin{array}{c}\text { Tamanho médio de } \\
\text { grão }(\boldsymbol{\mu m})\end{array}$ & $\begin{array}{c}\text { Desvio padrão } \\
\text { (DV) }\end{array}$ \\
\hline C-1250 & $1450 / 5 \mathrm{~min}$ & $2,37 \pm 0,06$ & 0,98 \\
C-1250 & $1450 / 10 \mathrm{~min}$ & $2,60 \pm 0,06$ & 1,03 \\
C-1250 & $1500 / 5 \mathrm{~min}$ & $3,40 \pm 0,07$ & 1,20 \\
M2-1350 & $1450 / 5 \mathrm{~min}$ & $3,19 \pm 0,08$ & 1,41 \\
M2-1350 & $1450 / 10 \mathrm{~min}$ & $3,35 \pm 0,09$ & 1,54 \\
M2-1350 & $1500 / 5 \mathrm{~min}$ & $4,07 \pm 0,08$ & 1,30 \\
Complexação de cátions & $1450 / 5 \mathrm{~min}$ & $2,79 \pm 0,08$ & 0,77 \\
Complexação de cátions & $1450 / 10 \mathrm{~min}$ & $3,56 \pm 0,12$ & 1,27 \\
Complexação de cátions & $1500 / 5 \mathrm{~min}$ & $4,37 \pm 0,20$ & 2,13 \\
\hline \hline
\end{tabular}

Menores tamanhos médios de grãos são obtidos para as amostras preparadas com calcinações sucessivas a $1250{ }^{\circ} \mathrm{C}$. A sinterização rápida favorece menor tamanho de grão quando comparado com a sinterização convencional. Ainda assim, todas as amostras estudadas apresentam grãos micrométricos.

As Figuras 63, 64 e 65 mostram o comportamento da condutividade elétrica dos grãos e contornos de grãos para as amostras preparadas com calcinações sucessivas a $1250{ }^{\circ} \mathrm{C}$, com duas calcinações a $1350{ }^{\circ} \mathrm{C}$ com 
moagens intercaladas, e pelo método de complexação de cátions obtidas por sinterização rápida.

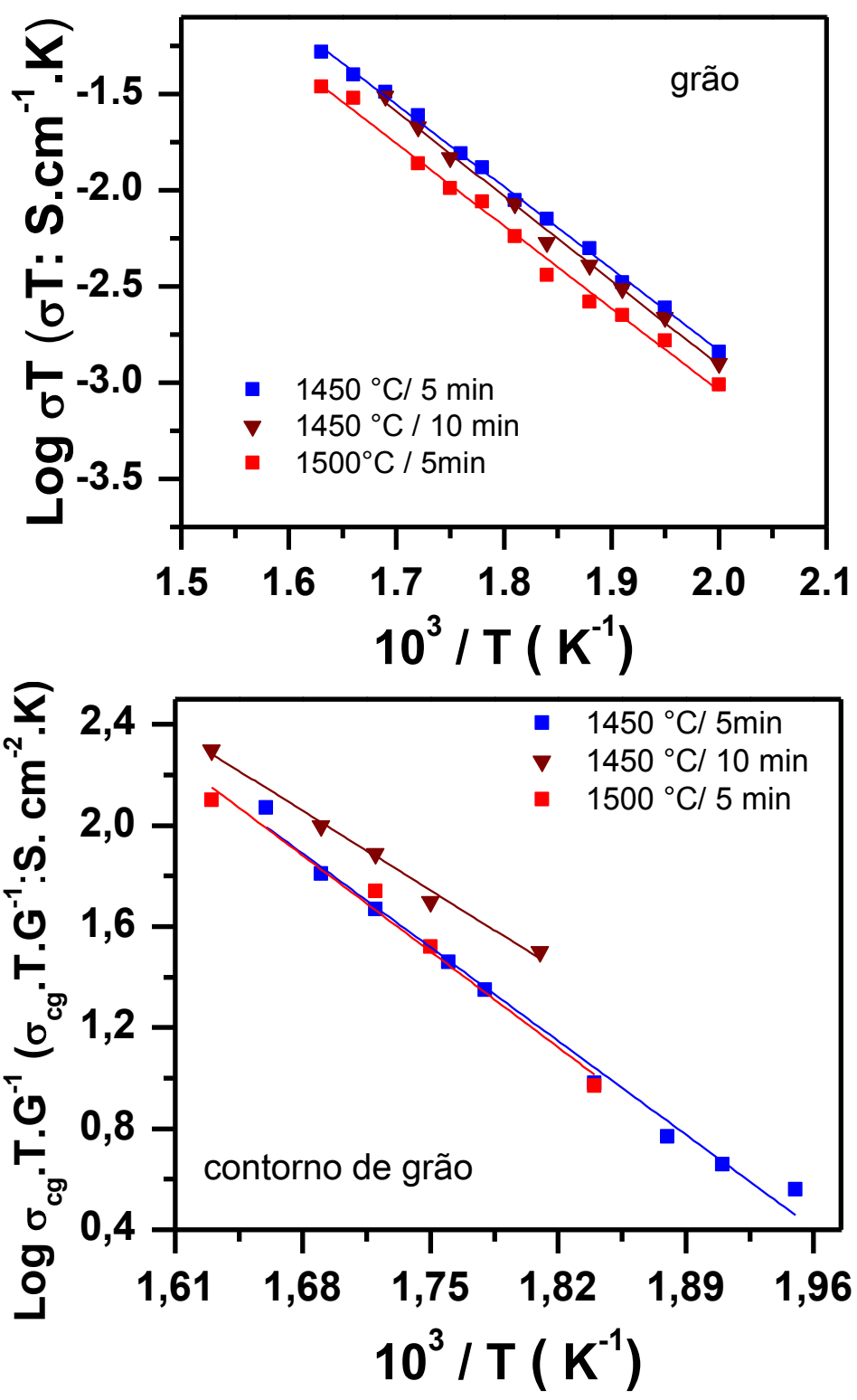

Figura 63: Gráficos de Arrhenius da condutividade elétrica dos grãos e contornos de grãos das amostras com calcinações sucessivas a $1250{ }^{\circ} \mathrm{C}$ e obtidas por sinterização rápida.

A condutividade iônica dos grãos nas amostras sinterizadas a $1500{ }^{\circ} \mathrm{C} /$ 5 min é inferior à das amostras sinterizadas a $1450{ }^{\circ} \mathrm{C} / 5$ ou $10 \mathrm{~min}$. Esse fenômeno pode estar relacionado ao teor das fases secundárias nessas condições, Figura 57. A condutividade dos contornos de grãos é superior para as amostras sinterizadas a $1450{ }^{\circ} \mathrm{C} / 10 \mathrm{~min}$. Isto pode estar relacionado com a 
menor quantidade de fases secundárias, como sugerem os resultados da Figura 57.
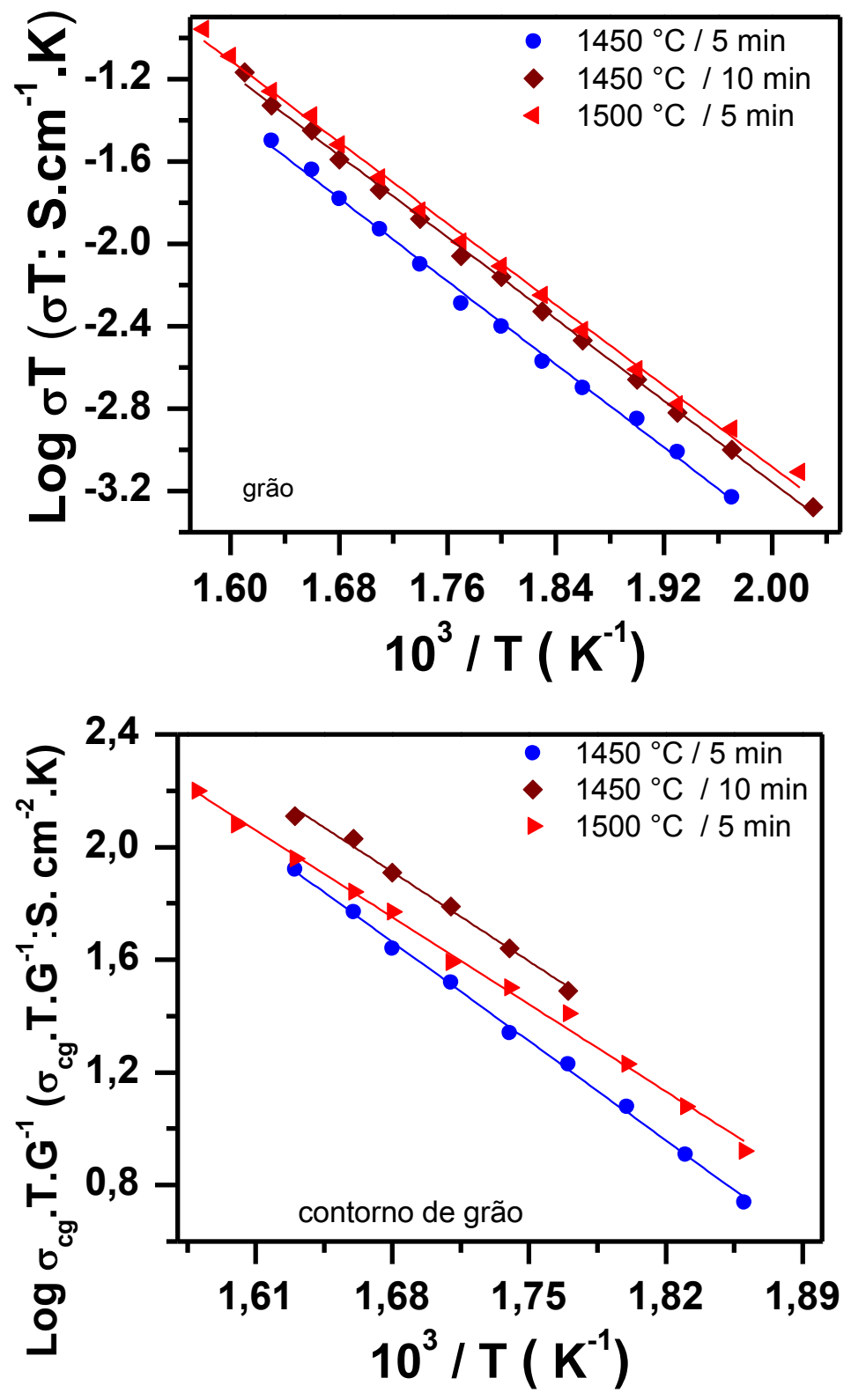

Figura 64: Gráficos de Arrhenius da condutividade elétrica dos grãos e contornos de grãos das amostras com duas calcinações a $1350{ }^{\circ} \mathrm{C}$ com moagens intercaladas e obtidas por sinterização rápida.

A condutividade dos grãos das amostras sinterizadas a $1450{ }^{\circ} \mathrm{C} / 10 \mathrm{~min}$ e $1500{ }^{\circ} \mathrm{C} / 5$ min são similares e superiores a das amostras sinterizadas por $1450{ }^{\circ} \mathrm{C} / 5$ min, Figura 64 . A condutividade do contorno de grão é superior as amostras sinterizadas a $1450^{\circ} \mathrm{C} / 10 \mathrm{~min}$. 


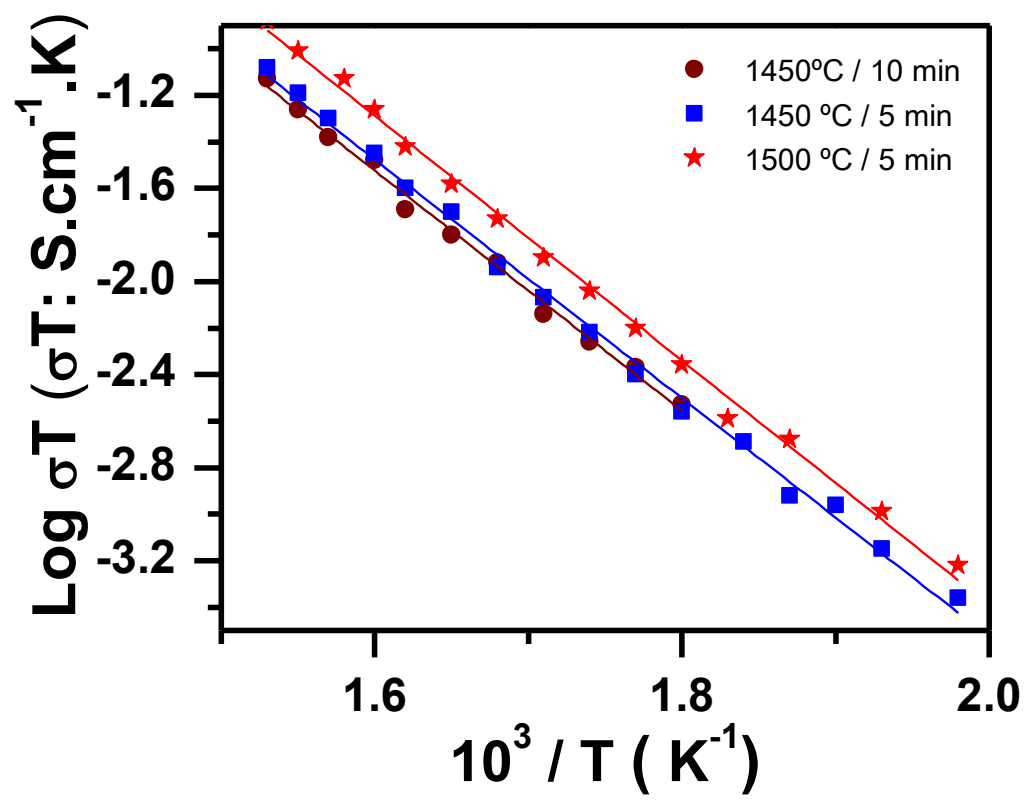

Figura 65: Gráficos de Arrhenius da condutividade elétrica dos grãos das amostras preparadas pelo método de complexação de cátions e obtidas por sinterização rápida.

As amostras preparadas pelo método de complexação e sinterizadas a $1500{ }^{\circ} \mathrm{C} / 5 \mathrm{~min}$ apresentaram condutividade do grão superior as sinterizadas a $1450{ }^{\circ} \mathrm{C}$ por 5 e $10 \mathrm{~min}$. Estes resultados sugerem que há diferentes teores composicionais que são dependentes da temperatura e do tempo de patamar.

As amostras obtidas por sinterização rápida e preparadas com calcinações sucessivas a $1250{ }^{\circ} \mathrm{C}$ apresentaram condutividade do grão e contorno de grão superior em relação às amostras preparadas com duas calcinações com moagens intercaladas, e por complexação de cátions sinterizadas nas mesmas condições. Isto provavelmente está associado as amostras com calcinações sucessivas a $1250{ }^{\circ} \mathrm{C}$ apresentarem maiores valores de densidade [115].

A condutividade elétrica das amostras obtidas por sinterização rápida é inferior às condutividades das amostras sinterizadas pelo método convencional. 
Tabela XIV- Valores de energia de ativação do processo de condução dos grãos $\left(\mathrm{E}_{\mathrm{g}}\right)$ contornos de grão $\left(\mathrm{E}_{\mathrm{cg}}\right)$ e total $\left(\mathrm{E}_{\mathrm{T}}\right)$, para amostras preparadas pelo método de mistura de óxidos e pelo método de complexação de cátions $(C)$ e valores de condutividade total na temperatura de $360^{\circ} \mathrm{C}$ para amostras preparadas pelo método de mistura de óxidos.

\begin{tabular}{|c|c|c|c|c|c|}
\hline $\begin{array}{l}\text { Método de } \\
\text { Síntese }\end{array}$ & $\begin{array}{c}\text { Condições } \\
\text { de } \\
\text { Sinterização } \\
\text { (o-C/ min) }\end{array}$ & $\begin{array}{c}E_{g} \\
(e V)\end{array}$ & $\begin{array}{l}E_{c g} \\
(e V)\end{array}$ & $\begin{array}{c}E_{T} \\
(e V)\end{array}$ & $\begin{array}{c}\sigma\left(10^{-5} \mathrm{~S} / \mathrm{cm}\right) \\
360^{\circ} \mathrm{C}\end{array}$ \\
\hline C-1250 & $1450 / 5$ & $0,84 \pm 0,05$ & $0,99 \pm 0,05$ & $0,95 \pm 0,05$ & 7,33 \\
\hline C- 1250 & $1450 / 10$ & $0,87 \pm 0,05$ & $0,87 \pm 0,05$ & $0,81 \pm 0,05$ & 6,71 \\
\hline C- 1250 & $1500 / 5$ & $0,84 \pm 0,05$ & $1,02 \pm 0,05$ & $0,86 \pm 0,05$ & 4,13 \\
\hline M2-1350 & $1450 / 5$ & $0,99 \pm 0,05$ & $0,98 \pm 0,05$ & $1,01 \pm 0,05$ & 4,26 \\
\hline M2-1350 & $1450 / 10$ & $0,98 \pm 0,05$ & $0,91 \pm 0,05$ & $0,98 \pm 0,05$ & 6,67 \\
\hline M2-1350 & $1500 / 5$ & $0,97 \pm 0,05$ & $0,87 \pm 0,05$ & $0,93 \pm 0,05$ & 6,36 \\
\hline
\end{tabular}

Os valores de energia de ativação para a condutividade dos grãos, contornos de grãos e total praticamente não variam para as amostras obtidas por sinterização rápida. A condutividade total é inferior a obtida para amostras sinterizadas convencionalmente. 


\section{CONCLUSÕES}

Para os pós preparados pelos dois métodos de síntese empregados, não foi possível obter pós sem fases secundárias, entretanto, calcinações com moagens intercaladas promoveram menor teor de fases secundárias para pós preparados pelo método de mistura de óxidos.

O método de complexação de cátions permitiu obter a fase ortorrômbica do LSGM nos pós em temperaturas inferiores em comparação aos pós preparados pelo método de mistura de óxidos.

Após as calcinações os materiais particulados são constituídos por aglomerados. Além disso, ocorre crescimento no tamanho das partículas e formação de pescoço. Maior uniformidade das partículas é obtida após a moagem.

Os compactos preparados de acordo com a sequência de três calcinações seguida de moagem apresentam maior retração linear que aqueles nos quais estas etapas foram alternadas. Nos pós preparados pelo método de complexação de cátions ocorre mudança na inclinação da curva de retração que esta associada com a formação de aglomerados. O método de complexação promoveu a aglomeração dos pós e morfologia e porosidade semelhantes para os pós.

Utilizando a sinterização convencional para os pós preparados pelo método de misturas de óxidos, foi possível obter a fase ortorrômbica do LSGM, entretanto, não foi possível eliminar as fases $\mathrm{SrLaGaO}_{4}, \mathrm{La}_{4} \mathrm{Ga}_{2} \mathrm{O}_{9}, \mathrm{SrLaGa}_{3} \mathrm{O}_{7}$ e $\mathrm{MgO}$, independente das condições de sinterização utilizadas.

A existência e os teores das fases secundárias são influenciados pelas etapas de calcinação e moagens realizadas em cada rota e também pelo método de síntese. O LSGM obtido pelo método de complexação de cátions, apresentou grãos de $\mathrm{MgO}$ identificados apenas por microscopia eletrônica de varredura.

Amostras obtidas com calcinações sucessivas a $1250^{\circ} \mathrm{C}$ e sinterizadas convencionalmente apresentaram maiores valores de densidades $\mathrm{e}$ condutividade iônica dos grãos e contornos de grãos quando comparadas com 
as outras rotas estudadas pelo método de mistura de óxidos e pelo método de complexação de cátions.

A sinterização rápida também promoveu a formação da fase ortorrômbica do LSGM e das fases secundárias. No material preparado pelo método de complexação, a sinterização rápida promoveu a formação de fases secundárias, $\mathrm{SrLaGaO}_{4}, \mathrm{La}_{4} \mathrm{Ga}_{2} \mathrm{O}_{9}$ e $\mathrm{SrLaGa}_{3} \mathrm{O}_{7}$, além de grãos $\mathrm{MgO}$, diferente do que foi observado utilizando o método convencional de sinterização.

O LSGM obtido por sinterização rápida possui menor tamanho médio de grãos e menor densidade quando comparado com a sinterização convencional. A condutividade elétrica das amostras obtidas por sinterização rápida é inferior às amostras sinterizadas pelo método convencional para ambos os métodos utilizados.

Os valores de energia de ativação para a condutividade dos grãos, contorno de grãos e total não variam com as condições utilizadas e estão de acordo com a literatura. 


\section{REFERÊNCIAS BIBLIOGRÁFICAS}

[1] Gool, W. V.; Fast ion transport in solids, North-Holland, Amsterdam, 1973.

[2] Hagenmuller, P.; Gool, W. V.; Solid electrolytes, Academic Press, New York, 1978.

[3] Subbarao, E. C.; Solid electrolytes and their applications, Plenun Press, New York, 1980.

[4] Lashtaberg, A.; Skinner, S. J.; Solid oxide fuel cells-a challenge for materials chemists?, J. Mater. Chem. v.16, p.3161-3170, 2006.

[5] Badwal, S. P. S.; Foger, K.; Solid oxide electrolyte fuel cell review, Ceram. Int., v.22, p.257-265, 1996.

[6] Zheng, F.; Bordia, R. K.; Pederson, L. R.; Phase constitution in Sr and Mg doped $\mathrm{LaGaO}_{3}$ system, Mater. Res. Bull., v.39, p.141-155, 2004.

[7] Li, S.; Li, Z.; Bergman, B.; Lanthanum gallate and ceria composite as electrolyte for solid oxide fuel cells, J. Alloy Compunds v.492, p.392-395, 2010.

[8] Ishihara, T.; Matsuda, H.; Takita Y.; Doped $\mathrm{LaGaO}_{3}$ perovskite type oxide as a new oxide ionic conductor. J. Am. Chem. Soc., v. 116, p. 3801-3803, 1994.

[9] Feng, M.; Goodenough, J. B.; A superior oxide-ion electrolyte. Eur. J. Solid State Inorg. Chem., v.31, p. 663-672, 1994.

[10] Li, S.; Bergman, B.; Doping effect on secondary phases, microstructure and electrical conductivities of $\mathrm{LaGaO} 3$ based perovskites. J. Eur. Ceram. Soc., v. 29 p.1139-1146, 2009.

[11] Djurado, E.; Labeu, M.; Second phases in doped lanthanum gallate perovskites. J. Eur. Ceram. Soc, v.18, p.1397- 1404, 1998.

[12] Lu, X. C.; Zhu, J. H.; Effect of $\mathrm{Sr}$ and $\mathrm{Mg}$ doping on the property and performance of the $\mathrm{La}_{1-x} \mathrm{Sr}_{x} \mathrm{Ga}_{1-y} \mathrm{Mg}_{y} \mathrm{O}_{3-\delta}$. J. Electrochem. Soc., v.155, p.B494-B503, 2008.

[13] Moure, A.; Castro, A.; Tartaj, J.; Moure, C.; Single-phase ceramics with $\mathrm{La}_{1-x} \mathrm{Sr}_{x} \mathrm{Ga}_{1-y} \mathrm{Mg}_{2} \mathrm{O}_{3-\delta}$ composition from precursors obtained by mechanosynthesis, J. Power Sources, v.188, p.489-497, 2009.

[14] Chiang, Y.M.; Birnie, D.; Kingery, W.D.; Physical Ceramics: Principles for Ceramic Science and Engineering, John Wiley \& Sons, 1997.

[15] Chroneos, A.; Vovk, R.V.; Goulatis, I.L.; Goulatis, L.I.; Oxygen transport in perovskite and related oxides: A brief review, J. Alloy Compounds, v. 494 p.190-195, 2010.

[16] Dhak, P.; Pramanik, P.; Bhattacharya, S.; Roy, A.; Achary, S. N.; Tyagi, A. K.; Structural phase transition in lanthanum gallate as studied by Raman and X-ray diffraction measurements, Phys. Status Solidi, v. B 248, p. 1884-1893, 2011. 
[17] Muccillo, E. N. S.; Condutores de íons oxigênio - uma breve revisão, Cerâmica, v. 54, p.129-144, 2008.

[18] Geller, S.; Crystallographic studies of perovskite-like compounds. IV. Rare earth scandates, vanadites, galliates, orthochromites, Acta Crystallogr. v.10, p.243-248, 1957.

[19] Marti, W; Fischer, P.; Altorfer, F.; Scheel, H. J.; Tadin, M.; Crystal structures and phase transitions of orthorhombic and rhombohedral RGa03 ( $\mathrm{R}=\mathrm{La}, \mathrm{Pr}, \mathrm{Nd}$ ) investigated by neutron powder diffraction, $\mathbf{J}$. Phys. Condens. Matter v. 6, p.127-135, 1994.

[20] Ishihara, T.; Matsuda, H.; Takita, Y. ; Effects of rare earth cations doped for La site on the oxide ionic conductivity of $\mathrm{LaGaO}$,-based perovskite type oxide Solid State Ionics, v.79, p.147-151, 1995.

[21] Huang, P. -N.; Petric, A.; Superior Oxygen Ion Conductivity of Lanthanum Gallate Doped with Strontium and Magnesium, J. Electrochem. Soc., v.143, p.1644-1648,1996.

[22] Azad, A-M.; Er, L. F.; Microstructural evolution in B-site Mg-substituted $\mathrm{La}_{0,9} \mathrm{Sr}_{0,1} \mathrm{GaO}_{3-\delta}$ oxide solid solutions, J. Alloys and Compounds, v. 306, p.103-112, 2000.

[23] Datta, P.; Majewski, P.; Aldinger, F. Synthesis and microstructural characterization of $\mathrm{Sr}$ - and $\mathrm{Mg}$-substituted $\mathrm{LaGaO}_{3}$ solid electrolyte, Materials Chemistry and Physics, v.102, p.240-244, 2007.

[24] Chen, Te-Y.; Fung, K.-Z.; Comparison of dissolution behavior and ionic conduction between $\mathrm{Sr}$ and/or $\mathrm{Mg}$ doped $\mathrm{LaGaO}_{3}$ and $\mathrm{LaAlO}_{3}, \mathbf{J}$. Power Sources, v.132 p.1-10, 2004.

[25] Zhao, X.; Li, X.; Xu, N.; Huang, K.; Beneficial effects of Mg-excess in $\mathrm{La}_{1-\mathrm{x}} \mathrm{Sr}_{x} \mathrm{Ga}_{1-\mathrm{y}} \mathrm{Mg}_{\mathrm{y}+\mathrm{z}} \mathrm{O}_{3-\delta}$ as solid electrolyte, Solid State Ionics, v.214, p.56-61, 2012.

[26] Liu, N.; Shi, M.; Wang, C.; Yuan, Y.P.; Majewski, M.; Aldinger, F. Microstructure and ionic conductivity of $\mathrm{Sr}$ - and $\mathrm{Mg}$-doped $\mathrm{LaGaO}_{3}, \mathbf{J}$. Mater. Sci., v.41, p. 4205-4213, 2006.

[27] Feng, M.; Goodenough, J. B.; Huang, K., Milliken, C., Fuel cells with doped lanthanum gallate electrolyte, J. Power Sources, v.63, p. 47-51, 1996.

[28] Ishihara, T.; Honda, M.; Shibayama, T.; Minami, H.; Minami, H.; Nishiguchi, Takita, H. Y.; J. Electrochem, v.145 p.3177, 1998.

[29] Huang, K.; Feng, M.; Goodenough, J. B.; Milliken, C.; Electrode Performance Test on single Ceramic Fuel Cells Using as electrolyte Srand Mg-Doped $\mathrm{LaGaO}_{3}$, J. Electrochem. Soc., v.144, p.3620-3624,1997.

[30] Morales, M.; Roa, J.J.; Tartaj, J.; Segarra, M.; Performance and short-term stability of single-chamber solid oxide fuel cells based on La0.9Sr0.1 $\mathrm{Ga}_{0.8} \mathrm{Mg}_{0.2} \mathrm{O}_{3-\delta}$ electrolyte, J. Power Sources, v.216, p.417-424, 2012. 
[31] Huang, K.; Tichy, R. S.; Goodenough, J. B.; Milliken, C.; Superior Perovskite Oxide-lon Conductor; Strontium- and Magnesium-Doped LaGaO3: III, Performance Tests of Single Ceramic Fuel Cells, J. Am. Ceram. Soc., v. 81, p. 2581-2585, 1998.

[32] Huang, K.; Goodenough, J. B.; A solid oxide fuel cell based on Sr- and Mgdoped $\mathrm{LaGaO}_{3}$ electrolyte: the role of a rare-earth oxide buffer, J. Alloys and Compounds, v. 303, p.454-464, 2000.

[33] Gong, W.; Gopalan, S.; Pal, U. B.; Performance of intermediate temperature $\left(600-800^{\circ} \mathrm{C}\right)$ solid oxide fuel cell based on $\mathrm{Sr}$ and $\mathrm{Mg}$ doped lanthanum-gallate electrolyte, J. Power Sources, v.160, p.305-315, 2006.

[34] Guo, W.; Liu, J.; Jin, C.; Anode-supported $\mathrm{LaGaO}_{3}$-based electrolyte SOFCs with $\mathrm{Y}_{2} \mathrm{O}_{3}$-doped $\mathrm{Bi}_{2} \mathrm{O}_{3}$ and La-doped $\mathrm{CeO}_{2}$ buffer layers, J. Alloys and Compounds, v.504, p.L21-L25, 2010.

[35] Hong, J.-E.; Inagaki, T.; Ida, S.; Ishihara, T.; Improved sintering and electrical properties of La-doped $\mathrm{CeO}_{2}$ buffer layer for intermediate temperature solid oxide fuel cells using doped $\mathrm{LaGaO}_{3}$ film prepared by screen printing process, J. Solid State Electrochem, v.16, p.1493-1502, 2012.

[36] Hong, J.-E.; Inagaki, Ishihara, T.; Preparation of $\mathrm{LaGaO3}$ thin film for intermediate temperature SOFC by screen printing method (I) LSGM as an effective sintering agent for La-doped $\mathrm{CeO}_{2}$ buffer layer, lonics, v.18, p.433-439, 2012.

[37] Zhang, X.; Ohara, S.; Okawa, H.; Maric, R.; Fukui, T.; Interactions of a La0.9Sro.1 $\mathrm{Ga}_{0.8} \mathrm{Mg}_{0.2} \mathrm{O}_{3-\delta}$ electrolyte with $\mathrm{Fe}_{2} \mathrm{O}_{3}, \mathrm{Co}_{2} \mathrm{O}_{3}$ and $\mathrm{NiO}$ anode materials, Solid State lonics v.139, p.145-152, 2001.

[38] Liu, X.; Meng, X.; Han, D.; Wu, H.; Zeng, F.; Zhan Z.; Impregnated nickel anodes for reduced-temperature solid oxide fuel cells based on thin electrolytes of doped LaGaO3, J. Power Sources, v.222, p.92-96, 2013.

[39] Drennan, J.; Zelizko, V.; Hay, D.; Ciacchi, F. T.; Rajendran, S.; Badwal, S. P. S.; Characterisation, conductivity and mechanical properties of the oxygen-ion conductor La0.9Sro.1 $\mathrm{Ga}_{0.8} \mathrm{Mg}_{0.2} \mathrm{O}_{3-\mathrm{x}}$, J. Mater. Chem., v.7, p.7983, 1997.

[40] Slater, P. R.; Irvine, J. T. S.; Ishihara, T. ; Takita, Y.; High-Temperature Powder Neutron Diffraction Study of the Oxide Ion Conductor La0.9Sro.1 $\mathrm{Ga}_{0.8 \mathrm{Mg}} \mathrm{Mg}_{2 .} \mathrm{O}_{2.85}$, J. Solid State Chemistry, v.139 p.135, 1998.

[41] Skowron, A.; -n Huang, P.; Petric, A.; Structural Study of La0.8Sro.2Ga0.85Mg0.15O2.825, J. Solid State Chemistry, v.143, p.202-209, 1999.

[42] Huang, K.; Tichy, R. S.; Goodenough, J. B.; Superior Perovskite Oxide-lon Conductor; Strontium- and Magnesium-Doped $\mathrm{LaGaO}_{3}$ : I, Phase Relationships and Electrical Properties, J. Am. Ceram.Soc., v.81, p.25652575,1998 . 
[43] Lerch, M.; Boysen H., Hansen, T.; High-temperature neutron scattering investigation of pure and doped lanthanum gallate, J. Physics and Chemistry of Solids v.62, p.445-455, 2001.

[44] Vasylechko, L.; Vashook, V.; Savytskii, D.; Senyshyn, A.; Niewa, R.; Knapp, M.; Ullmann, H.; Berkowski, M.; Matkovskii, A.; Bismayer, U.; Crystal structure, thermal expansion and conductivity of anisotropic La 1 ${ }_{x} \mathrm{Sr}_{x} \mathrm{Ga}_{1-2 x} \mathrm{Mg}_{2 \times} \mathrm{O}_{3-y} \quad(\mathrm{x}=0,05,0,1)$ single crystals, J. Solid State Chemistry, v.172 p.396-411, 2003.

[45] Yao, W.; Tang, Z.; Zhang, Z.; Luo, S.; Li, J.; Tan, Q.;Inter-relationship between crystal symmetry and ionic conductivity in doped $\mathrm{LaGaO}_{3}$, Materials Science and Engineering, v.B99, p.309-312, 2003.

[46] Datta, P.; Majewski, P.; Aldinger, F.; Structural studies of Sr- and Mgdoped LaGaO3, J. Alloys and Compounds,v. 438 p.232-237, 2007.

[47] Wu, Y-C.; Lee, M-Z. Properties and microstructural analysis of $\mathrm{La}_{1-x} \mathrm{Sr}_{x} \mathrm{Ga}_{1-y} \mathrm{Mg}_{2} \mathrm{O}_{3-\delta}$ solid electrolyte ceramic, Ceram. Inter., v.39, p.9331-9341, 2013.

[48] Rozumek, M.; Majewski, P.; Aldinger, F.; Metastable Crystal Structure of Strontium- and Magnesium-Substituted $\mathrm{LaGaO}_{3}, \mathrm{~J}$. Am. Ceram. Soc., v. 87, p. 656-61, 2004.

[49] Lybye, D.; Poulsen, F. W.; Mogensen, M.; Conductivity of A- and B-site doped $\mathrm{LaAlO}_{3}, \mathrm{LaGaO}_{3}, \mathrm{LaScO}_{3}$, and $\mathrm{LalnO}_{3}$ perovskites, Solid State lonics, v.128, p.91-103, 2000.

[50] Li, M.; Zhang, Y.; An, M.; Lü, Z.; Huang, X.; Xiao, J.; Wei, B.; Zhu, X.; Su,

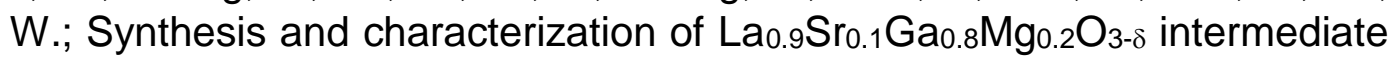
temperature electrolyte using conventional solid state reaction, J. Power Sources, v.218, p.233-236, 2012.

[51] Kurumada, M.; Hara, H.; Munakata, F.; Iguchi, E.; Electric conductions in La0.9Sro.1 $\mathrm{GaO}_{3-\delta}$ and $\mathrm{La}_{0.9} \mathrm{Sr}_{0.1} \mathrm{Ga}_{0.9} \mathrm{Mgg}_{0.1} \mathrm{O}_{3-\delta}$, Solid State Ionics, v.176, p.245-251, 2005.

[52] Zhang, J.; Liang, E.J.; Zhang, X.H.; Rapid synthesis of La0.9Sro.1 Ga0.8 $\mathrm{Mg}_{0.2} \mathrm{O}_{3-8}$ electrolyte by a $\mathrm{CO}_{2}$ laser and its electric properties for intermediate temperature solid state oxide full cells, J. Power Sources, v.195, p.6758-6763, 2010.

[53] Huang, K.; Feng, M.; Goodenough, J. B.; Wet chemical synthesis of Srand $\mathrm{Mg}$-doped $\mathrm{LaGaO}_{3}$, a perovskite-type oxide-ion conductor, J. Am. Chem. Soc., v.79, p.1100-1104, 1996.

[54] Weiyan, F.; Defeng, Z.; Guichun, Z.; Yanjie, X.; Jian, M.; Influence of A-site nonstoichiometry on microstructure and electrical properties of (La0.9Sr0.1) $\times \mathrm{Ga}_{0.8} \mathrm{Mg}_{0.2} \mathrm{O}_{3-\delta}(\mathrm{x}=0.97,1.00,1.03)$ electrolyte materials, Solid State Sciences, v.13, p.110-114, 2011.

[55] Ullmann, H.; Trofimenko, N.; Naoumidis, A.; StÖver, D. Ionic/electronic Mixed Conduction Relations in Perovskite-type Oxides by Defect Structure, J. Euro. Ceram. Soc., v.19, p.791-796, 1999. 
[56] Ullmann, H.; Trofimenko, N.; Composition, structure and transport properties of perovskite-type Oxides, Solid State Ionics, v.119, p.1-8, 1999.

[57] Ishihara, T.; Furutani, H.; Honda, M.; Yamada, T.; Shibayama, T.; Akbay, T.; Sakai, N.; Yokokawa, H.; Takita, Y.; Improved Oxide lon Conductivity in

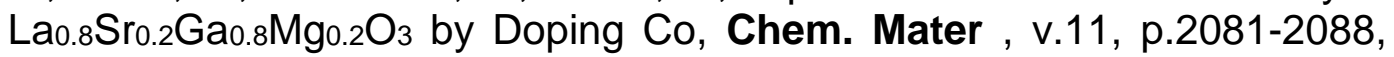
1999.

[58] Yaremchenko, A.A.; Shaula, A.L.; Logvinovich, D.I.; Kharton, V.V. ; Kovalevsky, A.V.; Naumovich, E.N.; Frade , J.R. ; Marques, F.M.B.; Oxygen-ionic conductivity of perovskite-type $\mathrm{La}_{1-x} \mathrm{Sr}_{x} \mathrm{Ga}_{1-y} \mathrm{Mg}_{y} \mathrm{M}_{0.2} \mathrm{O}_{3-\delta}$ $(\mathrm{M}=\mathrm{Fe}, \mathrm{Co}, \mathrm{Ni})$, Materials Chemistry and Physics,v.82, p.684-690, 2003.

[59] Sammes, N. M.; Tompsett, G.A.; Phillips, R.J.; Cartner, A. M.; Characterisation of doped-lanthanum gallates by X-ray diffraction and Raman spectroscopy,Solid State Ionics, v.111, p.1-7, 1998.

[60] Rozumek, M.; Majewski, P.; Aldinger, F.; Künstler, K.; Tomandl, G.; Preparation and Electrical Conductivity of Common Impurity Phases in (La,Sr) $(\mathrm{Ga}, \mathrm{Mg}) \mathrm{O}_{3}$ Solid Electrolytes, cfi/Ber. DKG v. 80 n. 4, p.E35 -E40, 2003.

[61] Wolfenstine, J.; Rate-controlling species for creep of the solid state electrolyte: doped lanthanum gallate, Solid State Ionics, v.126 p.293-298, 1999.

[62] Wolfenstine J.; Huang, P.; Petric, A., Creep behavior of doped lanthanum gallate versus cubic zircônia, Solid State lonics, v.118, p.257-259, 1999.

[63] Hayashi, H.; Suzuki, M.; Inaba, H.; Thermal expansion of Sr- and Mgdoped $\mathrm{LaGaO}_{3}$, Solid State lonics, v.128, p.131-139, 2000.

[64] Cheng, J.; Navrotsky A., Energetics of magnesium, strontium, and barium doped lanthanum gallate perovskites, J. Solid State Chemistry v.177, p.126-133, 2004.

[65] Stijepovic, I.; Darbandi, A. J.; Srdic, V. V.; Conductivity of Co and Ni doped lanthanum-gallate synthesized by citrate sol-gel method, Ceramics International, v.39, p.1495-1502, 2013,.

[66] Stevenson, J. W.; Armstrong, T. R.; McCready, D. E.; Pederson, L. R.; Weber, W. J.; Processing and Electrical Properties of Alkaline EarthDoped Lanthanum Gallate, J. Eletrochem.Soc., v.144, p.3613-3620, 1997.

[67] Stevenson, J.W.; Armstrong, T.R.; Pederson, L.R.; Li, J.; Lewinsohn, C.A.; Baskaran, S.; Effect of A-site cation nonstoichiometry on the properties of doped lanthanum gallate Solid State lonics, v.113-115, p.571,1998.

[68] Cong, L.; He, T.; Ji, Y.; Guan, P.; Huang, Y.; Su, W.; Synthesis and characterization of IT-electrolyte with perovskite structure $\mathrm{La}_{0,8} \mathrm{Sr}_{0,2} \mathrm{Ga}_{0,85} \mathrm{Mg}_{0,15} \mathrm{O}_{3-8}$ by glycine-nitrate combustion method, J. Alloys and Compounds, v. 348, p.325-331, 2003. 
[69] Majewski, P.; Rozumek, M.; Tas, A. C.; Aldinger, F.; Processing of ( $\mathrm{La}, \mathrm{Sr})(\mathrm{Ga}, \mathrm{Mg}) \mathrm{O}_{3}$ Solid Electrolyte, J. Electroceram. v. 8, p.65-73, 2002.

[70] Lapina, A.; Li, S.; Bergman, B.; Zhao, Z.; Synthesis of La0.9Sro. $\mathrm{Ga}_{0.8} \mathrm{Mg}_{0.2} \mathrm{O}_{2.85}$ powder by gel combustion route with two-step doping strategy, J. Euro. Ceram. Soc., v.32, p.2325-2331, 2012.

[71] Shi, M. ; Chen, M. ; Zuo, R. ; Xu, ; Su, H. ; Wang, L. ; Yu, T. ; Synthesis and characterization of $\mathrm{La} 0.85 \mathrm{Sr} 0.15 \mathrm{Ga} 0.80 \mathrm{Mg}_{0.20} \mathrm{O}_{2.825}$ by glycine combustion method and EDTA combustion method, Powder Technology, v. 204, p.188-193, 2010.

[72] T. Mathews, J.R. Sellar, Observation of diffuse electron scattering in Srand Mg-doped $\mathrm{LaGaO}_{3}$, Solid State lonics, v.135, p.411-417, 2000.

[73] Rozumek, M. ; Majewski, P.; Sauter, L.; Aldinger, F.; Homogeneity Region of Strontium- and Magnesium-Containing $\mathrm{LaGaO}_{3}$ at Temperatures between 1100 and $1500{ }^{\circ} \mathrm{C}$ in Air, J. Am. Ceram. Soc., v.86 n.11, p.1940-46, 2003.

[74] Ha, S. B.; Cho, Y. H.; Kang, Y. C.; Lee, J.-H.; Lee, J.-H.; Effect of oxide additives on the sintering behavior and electrical properties of strontiumand magnesium-doped lanthanum gallate, J. Euro. Ceram. Soc., v.30, p.2593-2601, 2010.

[75] Ha, S. B.; Cho, Y. H.; Ji, H-I.; Lee, J-H.; Kang Y. C.; Lee, J-H.; Lowtemperature sintering and electrical properties of strontium-and magnesium-doped lanthanum gallate With $\mathrm{V}_{2} \mathrm{O}_{5}$ additive, J. Power Sources, v.196, p.2971-2978, 2011.

[76] Schulz, O.; Martin, M.; Preparation and characterisation of $\mathrm{La}_{1-x} \mathrm{Sr}_{x} \mathrm{Ga}_{1-y} \mathrm{Mg}_{y} \mathrm{O}_{3-(x+y) / 2}$ for the investigation of cation diffusion processes, Solid State lonics v.135, p.549-555, 2000.

[77] Min Shi, Y. Xu, A. Liu, N. Liu, C. Wang, P. Majewski, F. Aldinger, Synthesis and characterization of Sr- and Mg-doped Lanthanum gallate electrolyte materials prepared via the Pechini method, Materials Chemistry and Physics, v.114, p.43-46, 2009.

[78] Tas, A. C.; Majewski, P.J.; Aldinger, F.; Chemical preparation of pure and strontium- and/ or magnesium-doped lanthanum gallate powder, J. Am. Ceram. Soc., v. 83, p. 2954-2960, 2000.

[79] Polini, R.; Pamio, A.; Traversa, E.; Effect of synthetic route on sintering behavior, phase purity and conductivity of $\mathrm{Sr}$ - and $\mathrm{Mg}$-doped $\mathrm{LaGaO}_{3}$ perovskites, J. Eur. Ceram. Soc., v. 24, p. 1365-1370, 2004.

[80] Cho, P.-S.; Park, S. -Y.; Cho, Y. Ho; Kim S. -J.; Kang, Y. C.; Mori, T.; Lee, J. -H; Preparation of LSGM powders for low temperature sintering, Solid State lonics v. 180 p. 788-791, 2009

[81] Pelosato, R.; Cristiani, C.; Dotelli G.; Latorrata, S.; Ruffo, R.; Zampori, L.;Co-precipitation in aqueous medium of $\mathrm{La} 0.8 \mathrm{Sr}_{0.2} \mathrm{Ga}_{0.8 \mathrm{Mg}} \mathrm{Mg}_{0.2} \mathrm{O}_{3-8}$ via inorganic precursors, J. Power Sources, v.195, p.8116-8123 , 2010. 
[82] Chen, T.-Y.; Fung, K.-Z.; Synthesis of and densification of oxygenconducting La $0.8 \mathrm{Sr}_{0.2} \mathrm{Ga}_{0.8} \mathrm{Mg}_{0.2} \mathrm{O}_{2.8 n a n o}$ powder prepared from alow temperature hydrothermal urea precipitation process, J. Euro. Ceram. Soc., v. 28, p. 803-810, 2008.

[83] Oncel, C.; Ozkaya, B.; Ali Gulgun, M.; X-ray single phase LSGM at 1350 C, J. Eur. Ceram. Soc., v.27, p.599-604, 2007.

[84] Weitkamp, J.; WiemhÖfer, H.-D.; Electronic conduction and stability of solid electrolytes based on lanthanum gallates, Solid State lonics v.154155, p.597-604, 2002.

[85] Traina, K.; Henrist, C.; Vertruyen, B.; Cloots, R.; Dense La0.9Sro.1 Ga0.8 $\mathrm{Mg}_{0.2} \mathrm{O}_{2.85}$ electrolyte for IT-SOFC's: Sintering study and electrochemical characterization, J. Alloys and Compounds, v.509, p.1493-1500, 2011.

[86] López, D. M.; Morales, J.C. R.; Martínez, J. P.; Sedeño, M.C. M.; Barrado, J.R. R.; Influence of phase segregation on the bulk and grain boundary conductivity of LSGM electrolytes, Solid State lonics, v.186, p.44-52, 2011.

[87] Raghvendra, Singh, R. K.; Singh, P.; Synthesis of La0.9Sr0.1 $\mathrm{Ga}_{0.8} \mathrm{Mg}_{0.2} \mathrm{O}_{3-\delta}$ electrolyte via ethylene glycol route and its characterizations for IT-SOFC, Ceramics International, v.40, p.7177-7184, 2014.

[88] Morales, M.; Roa, J. J.; Falcón, J. M. P.; Moure, A.; Tartaj, J.; Segarra, M.; Electrical and mechanical characterization by instrumented indentation technique of $\mathrm{La}_{0.85} \mathrm{Sr}_{0.15} \mathrm{Ga}_{0.8} \mathrm{Mgg}_{0.2} \mathrm{O}_{3-\delta}$ electrolyte for SOFCs, J. Euro. Ceram. Soc., v.32, p.4287-4293, 2012.

[89] Morales, M.; Roa, J. J.; Falcón, J. M. P.; Moure, A.; Tartaj, J.; Espiell, F , Segarra, M.; Correlation between electrical and mechanical properties in $\mathrm{La}_{1-\mathrm{x}} \mathrm{Sr}_{x} \mathrm{Ga}_{1-y} \mathrm{Mg}_{\mathrm{y}} \mathrm{O}_{3-\delta}$ ceramics used as electrolytes for solid oxide fuel cells, J. Power Sources, v.246, 918-925, 2014.

[90] Liu, B.; Zhang, Y.; La0.9Sro.1 $\mathrm{Ga}_{0.8} \mathrm{Mg}_{0.2 \mathrm{O}_{3}-\delta}$ sintered by spark plasma sintering (SPS) for intermediate temperature SOFC electrolyte, J. Alloys and Compounds, 458 (2008) 383.

[91] Maglia, F.; Tamburini, U. A.; Chiodelli, G.; Çamurlu, H.E.; Dapiaggi, M.; Munir, Z.A.; Electrical, structural, and microstructural characterization of nanometric La0.9Sro.1Ga0.8 $\mathrm{Mg}_{0.2} \mathrm{O}_{3}-\delta$ (LSGM) prepared by high-pressure spark plasma sintering, Solid State lonics v.180, p.36-40, 2009.

[92] Borodianska, H.; Badica, P.; Uchikoshi, T. Sakka, Y.; Vasylkiv, O.; Nanometric La $\mathrm{L}_{0.9} \mathrm{Sr}_{0.1} \mathrm{Ga}_{0.8} \mathrm{Mg}_{0.2} \mathrm{O}_{3-x}$ ceramic prepared by low-pressure reactive spark-plasma-sintering, J. Alloys Compounds, v.509 p.25352539, 2011.

[93] Zhai, Y.; Ye, C.; Xia, F.; Xiao, J.; Dai, L.; Yang, Y.; Wang, Y.; Preparation of $\mathrm{La}_{0.8} \mathrm{Sr}_{0.2} \mathrm{Ga}_{0.83} \mathrm{Mg}_{0.17} \mathrm{O}_{2.815}$ powders by microwave-induced poly(vinyl alcohol) solution polymerization, J. Power Sources, v.162, p.146-150, 2006. 
[94] Zhai, Y.; Ye, C.; Xiao, J.; Dai, L.; A microwave-induced solutionpolymerization synthesis of doped LaGaO3 powders, J. Power Sources, v.163 p.316-322, 2006.

[95] Boldrini, S.; Mortalò, C .; Fasolin, S.; Agresti, F.; Doubova, L.; Fabrizio, M.; Barison, S.; Influence ofMicrowave-Assisted Pechini Method on La $0.80 \mathrm{Sr}_{0.20} \mathrm{Ga}_{0.83} \mathrm{Mg}_{0.17} \mathrm{O}_{3-\delta}$ Ionic Conductivity, Fuel Cells, v.12, n. 1, p.54-60, 2012.

[96] Coutry, P.; Delmon, B.; Marcilly, C. Surgier, A; FR Patent $n^{\circ}$ 1.604.707, 1968.

[97] Taguchi, H.; Matsu-ra, S.; Nagao, M.; A solid oxide fuel cell based on Srand $\mathrm{Mg}$-doped $\mathrm{LaGaO}_{3}$ electrolyte: the role of a rare-earth oxide buffer, $\mathrm{J}$. Solid State Chem., v.129, p.60-65, 1997.

[98] Courty, P.; Ajot H.; Marcilly, C.; Oxydes Mixtes on en Solution Solide sous Forme Très Divisèe Obtenus par Dècomposition Thermique de Prècurseurs Amorphes, Powder Techonology, v. 7, p.21-38, 1973.

[99] Marcilly, C.; Coutry, P.; Delmon, B.; J. Am. Ceram. Soc., v.53, p.56-57, 1970.

[100] Leaver, N.E., Mistler, R.E.; Am. Ceram. Soc. Bull., v.51, p.845, 1972.

[101] Locsei, B.P.; Ceramurgia v.4, p.242, 1974.

[102] Silva, A. G. P.; Júnior, C. Alves, Solid phase sintering theory; a critical analysis of its practical application, Cerâmica v.44, p.289, 1998.

[103] Yoo, Y.-S.; Kim, J.-J.; Kim, D.-Y.; Effect of Heating Rate on the microstructural Evolution During of $\mathrm{BaTiO}_{3}$ Ceramics, J. Am. Ceram. Soc., v.70, p.C322-324, 1987.

[104] Kang, S.-J L. Sintering Densification, Grain Growth \& Microstructure, Elsevier Burlington, 2005.

[105] Garcia, D. E.; Klein, A. N.; Hotza, Advanced Ceramics with Dense and Fine-Grained Microstructures through Fast Firing, D. Rev. Adv. Mater. Sci. v.30, p.273-281, 2012.

[106] Harmer, M.P.; Roberts, E.W.; Brook, R.J.; Trans. Br. Ceram. Soc. v.78, p.22,1979.

[107] Garcia, D. E.; Seidel, J; Janssen, R; Claussen , N.; Fast firing of alumina, J. Eur. Ceram. Soc. v.15, p.935-938, 1995.

[108] Lin, F.J.T.; Jonghe , L.C. De, Rahaman , M.N., Initial Coarsening and Microstructural Evolution of Fast-Fired and MgO-Doped $\mathrm{Al}_{2} \mathrm{O}_{3}$, J. Am. Ceram. Soc. v.80, p.2891-2896,1997.

[109] Feng, C.; Qiu, H.; Guo, J.; Yan, D.; Schulze, W.A.; J. Mater. Synth. Proces., v.3 p.25, 1995.

[110] Feng, C.; Shi, E.; Guo, J.; Yan, D.; Schulze, W.A.; J. Mater. Synth. Process. v.3, p.31, 1995. 
[111] Pereira, G.J.; Castro, R.H.R., Muccillo, E. N. S.; Florio, D.Z. De, Densification and electrical conductivity of fast fired manganese-doped ceria ceramics, Mater. Letters, v.59, p.1195, 2005.

[112] Mendelson, M. J.; Average Grain Size in Polycrystalline Ceramics, J. Am. Ceram. Soc., v.52, p.443-446,1969.

[113] Kleitz, M. K.; Kennedy, J. H., Resolution of multicomponents impedance diagrams. In:Proceedings of the International Conference on Fast lon Transport in solids, eletroctodes and Electrolytes, Ed. P. Vashishta, J. N.Mundy, G. K. Shenoy, North-Holland, Amsterdam, p. 1858, 1979.

[114] Reis, S. L.; Muccillo, E. N. S.; Muccillo, E.N.S. .Effect of Attrition Milling and Calcination Temperature on Phase Composition of Strontium-and Magnesium-Doped Lanthanum Gallate. Materials Science Forum, v.727728, p.516-521, 2012.

[115] Reis, S. L.; Muccillo. E.N.S.; Structure and ionic conductivity of fast fired $\mathrm{La}_{0,9} \mathrm{Sr}_{0,1} \mathrm{Ga}_{0,8} \mathrm{Mg}_{0,2} \mathrm{O}_{3-\delta}$ solid electrolyte, Adv. Mater. Res. Aceito 